UNIVERSIDADE DE SÃO PAULO

MUSEU DE ZOOLOGIA

Joice Paulo Constantini

\title{
Estudo taxonômico dos Apicotermitinae da Mata Atlântica
}

Volume I

-São Paulo- 


\section{JOICE PAULO CONSTANTINI}

Estudo taxonômico dos Apicotermitinae da Mata Atlântica

\section{Volume I}

Versão corrigida

Tese apresentada ao Museu de Zoologia da Universidade de São Paulo para obtenção do título de Doutora em Ciências.

Área de Concentração: Sistemática, Taxonomia Animal e Biodiversidade

Orientadora: Eliana Marques Cancello

-São Paulo- 
Autorizo a reprodução e divulgação total ou parcial deste trabalho, por qualquer meio convencional ou eletrônico, para fins de estudo e pesquisa, desde que citada a fonte.

\author{
Catalogação na Publicação \\ Serviço de Biblioteca e Documentação \\ Museu de Zoologia da Universidade de São Paulo \\ Ficha catalográfica: Dione Seripierri - CRB8/3805
}

Constantini, Joice Paulo

Estudo taxonômico dos Apicotermitinae da Mata Atlântica./ Joice Paulo Constantini; orientadora Eliana Marques Cancello. São Paulo, 2018.

$2 \mathrm{v}$.

Versão corrigida

Tese Doutorado - Programa de Pós-Graduação em Sistemática, Taxonomia e Biodiversidade, Museu de Zoologia, Universidade de São Paulo, 2018. 
Nome: Constantini, Joice Paulo

Título: Estudo taxonômico dos Apicotermitinae da Mata Atlântica

Tese apresentada ao Museu de Zoologia da Universidade de São Paulo para obtenção do título de Doutora em Ciências

Aprovada em: 11/10/2018

Banca Examinadora

Profa Dra Eliana Marques Cancello - presidente da banca

Instituição: Museu de Zoologia da USP

Profa Dra Fabiana E. Casarin dos Santos

Instituição: Universidade Federal de São Paulo

Prof. Dr. Ives Haifig

Instituição: Universidade Federal do ABC

Prof. Dr. Agno Nonato Serrão Acioli

Instituição: Universidade Federal do Amazonas

Dr. Maurício Moura Rocha

Instituição: Museu de Zoologia da USP 


\section{AGRADECIMENTOS}

À minha orientadora Eliana Cancello pelo tempo dedicado à minha formação, toda paciência e conselhos.

À Fundação de Amparo à Pesquisa do Estado de São Paulo e à Coordenação de Aperfeiçoamento de Pessoal de Nível Superior pela concessão da bolsa de doutorado (Processo FAPESP 2014/11982-1 e Capes Demanda Social/PROAP) e pelo apoio financeiro para a realização desta pesquisa.

Ao curador do AMNH, David Grimaldi, e sua colaboradora Courtney Richenbacher que fizeram todo o possível para que minha estadia fosse o mais proveitosa possível. Ao curador do USNM Floyd Shockley, pelo empréstimo de material.

Ao professor Reginaldo Constantino e à Carolina Cuezzo que compartilharam informações sobre os tipos por ocasião de suas visitas às coleções norte-americanas.

Aos colegas do Laboratório de Hymenoptera do MZUSP pelo uso do sistema de automontagem e à Gabriel Biffi pelo trabalho com parte das fotos desse trabalho.

Aos colegas do Laboratório de Ortopteroides, pelos valiosos ensinamentos sobre trabalho em equipe.

A todos os colegas do Museu de Zoologia e aos funcionários que fizeram os dias mais leves e cheios de sorrisos.

Ao Tiago, amigo que me acolheu num momento muito agudo da vida, leu este texto oferecendo sugestões importantes, e colaborou com o tratamento de parte das fotos.

A minha família que sempre depositou sua confiança em mim. 
Eu sei de todo caminho que andei Sou feito de barro batido e berro Sempre topei com madeira de lei A ciência já me fez cupim de ferro (Cupim de Ferro, Lenine, 2015) 


\section{Resumo}

Constantini, JP. 2018. Estudo taxonômico dos Apicotermitinae da Mata Atlântica

Palavras-chave: cupins, térmitas, morfologia comparada, operários, tubo digestório

Apesar de sua relevância ecológica, os Apicotermitinae neotropicais foram taxonomicamente pouco estudados, e nenhum trabalho abrangente de morfologia comparada foi feito sobre eles. Portanto, há uma lacuna na compreensão da variação apresentada por alguns caracteres (especialmente do tubo digestório) em todo o grupo. A morfologia interna e externa de 600 amostras de Apicotermitinae da Mata Atlântica depositadas no MZUSP, juntamente com os tipos do American Museum of Natural History (Nova Iorque) e do Smithsonian Institution National Museum (Washington, DC), foi estudada. 0 tubo digestório, incluindo a válvula entérica, foi analisado para cada espécie tratada aqui. Foram identificadas 35 espécies, sendo 20 delas ainda não descritas, e outras 15 espécies já conhecidas, cujas áreas de distribuição foram ampliadas. 0 estudo do material tipo possibilitou a melhoria das descrições de espécies, cujos diagnósticos eram problemáticos. As descrições e redescrições de todas as espécies foram incluídas, bem como ilustrações das principais características, estudo morfométrico e mapas de amostragem. Também foram incluídos comentários sobre o status do material tipo, um breve estudo comparativo de todas as espécies neotropicais e uma chave de identificação baseada nos operários para essas espécies. O estudo comparado deu suporte para novas hipóteses de agrupamento das espécies no nível de gênero, e permitiu avaliar caracteres informativos que têm sido negligenciados em artigos publicados recentemente, como: diferenças nas mandíbulas de operários e alados da mesma espécie, especialmente na região molar, dimorfismo sexual nos alados, presença de órgãos deiscentes no tórax e nos primeiros segmentos abdominais do operário. Conclui-se que é fundamental o estudo da morfologia externa e interna do operário e morfologia externa do alado de forma combinada para um bom diagnóstico em nível específico e genérico, não considerando apenas uma característica (como a válvula entérica) para a separação de táxons. As descrições desses novos táxons permitirão estudos faunísticos comparáveis, levando a um melhor entendimento desse grupo nos ecossistemas neotropicais. 


\begin{abstract}
Constantini, JP. 2018. Taxonomic study of Atlantic Forest Apicotermitinae
\end{abstract}

Keywords: termites, comparative morphology, workers, digestive tube

Despite their ecological relevance, the Neotropical soldierless termites were not taxonomically studied enough, and no comprehensive comparative morphology study has been done. Therefore, there is a gap in the understanding of the character variation (mainly those of the gut) in the whole group. External and internal morphology of 600 samples of Apicotermitinae from the Atlantic Forest housed in the MZUSP were studied, along with the types from the American Museum of Natural History (New York) and the Smithsonian Institution National Museum (Washington, DC). The digestive tube, including the enteric valve, of each species herein treated were studied. Thirty five species were identified in total, out of which 20 are undescribed, and the other 15 already described have had an extension of their known distribution. The study of the type material have improved the descriptions of species, whose diagnosis were problematic. Descriptions and re-descriptions of all species were provided, as well as illustrations of the main characteristics, morphometric study and sampling maps. There were also comments on the status of the type material, and a brief comparative study of all Neotropical species plus an identification key for these, based on workers. The comparative study supports the new hypotheses of grouping species at the genus level, and allowed an evaluation of the informative characters often neglected in recent published articles, such as: differences in the mandibles of workers and imagoes of the same species, mainly in the molar region; alate sexual dimorphism; presence of dehiscent organs in the thorax and first abdominal segments in workers. In conclusion, a combined study of both the external and internal morphology of the worker and the external morphology of the alate is fundamental to diagnose both the specific and generic level well, not just taking into consideration one characteristic (such as the enteric valve) to split taxons. Descriptions of the new taxa will enable comparisons among faunistic studies already published, leading to a better understanding of this group in Neotropical ecosystems. 


\section{Sumário}

\section{VOLUME I}

1. Introdução

1.1. Histórico Taxonômico dos Apicotermitinae da Região Neotropical .........................................................17

1.2. Justificativa para o recorte adotado neste trabalho ………............................................................................

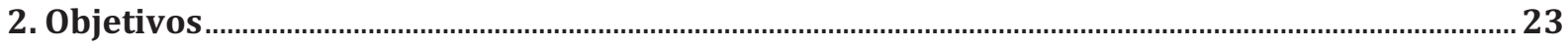

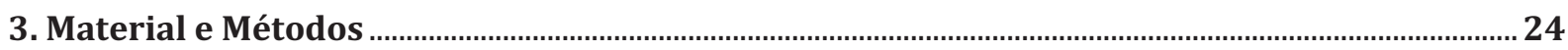

3.1. Lista de Acrônimos das instituições citadas …………………………………………………………......24

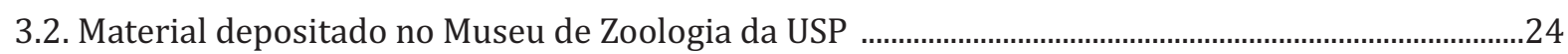

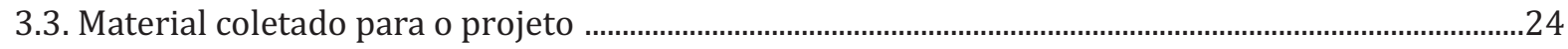

3.4. Visita à coleção de Isoptera do Americam Museum of Natural History ………………………………...25

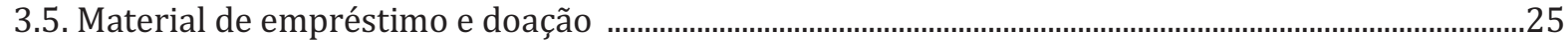

3.6. Estudo da morfologia externa e interna ..................................................................................................2

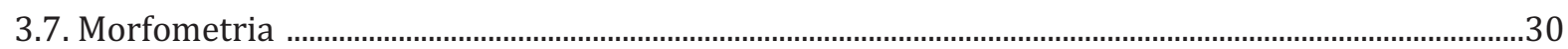

3.8. Ilustração, mapa e material examinado ........................................................................................................31

3.9. Chave de identificação ...........................................................................................................................

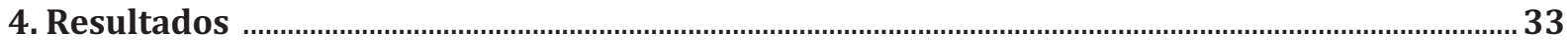

4.1. Apicotermitinae da Região Neotropical ("Grupo Anoplotermes") .......................................................34

4.2. Chave para os operários das espécies e grupos de Apicotermitinae neotropicais ............................37

4.3. Redescrições e considerações sobre o status de parte dos tipos de Apicotermitinae ......................40

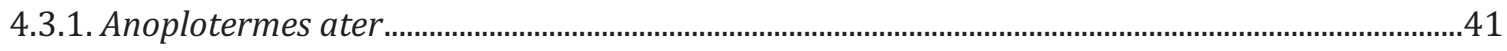

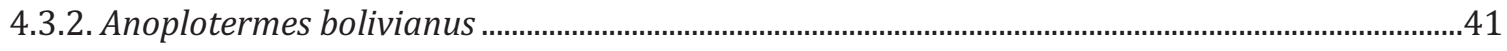

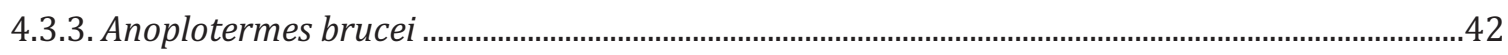

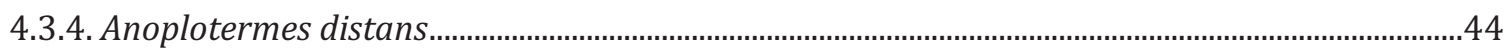

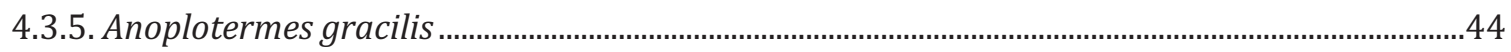

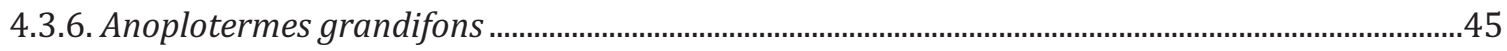

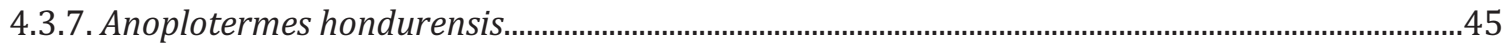

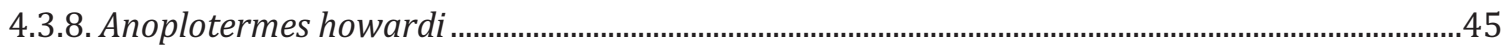

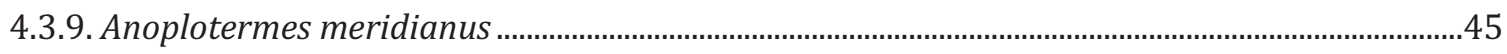

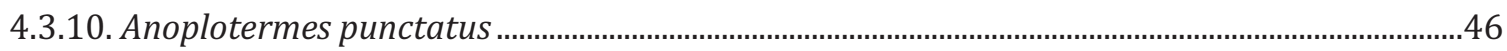

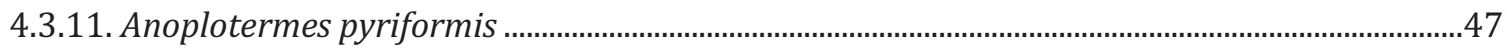

4.3.12. Anoplotermes rotundus .................................................................................................................4

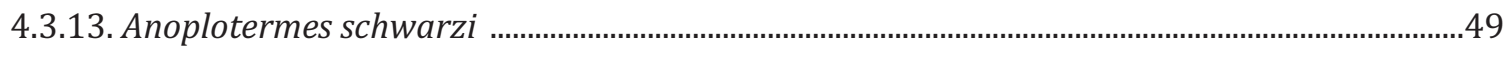

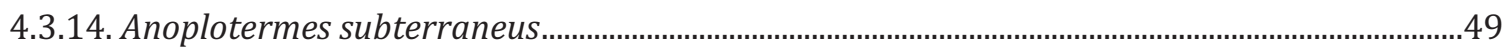

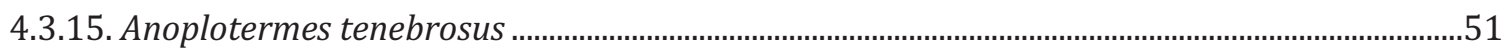

4.3.16. Aparatermes abbreviatus ………….................................................................................. 51

4.3.17. Anoplotermes cingulatus …………………………...................................................................... 
4.3.18. Anoplotermes silvestrii

4.4. Descrições e redescrições das espécies de Apicotermitinae da Mata Atlântica ................................54

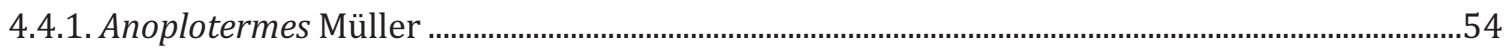

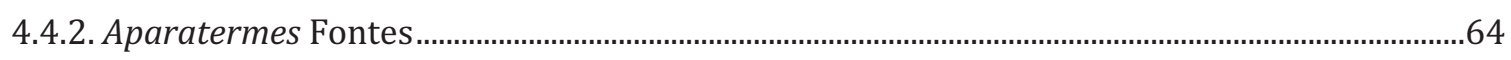

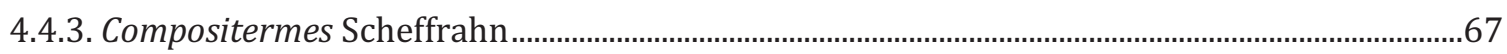

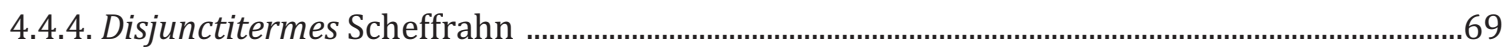

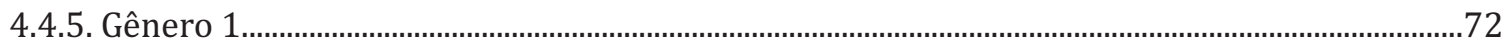

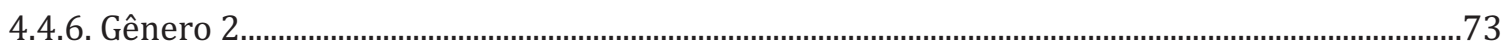

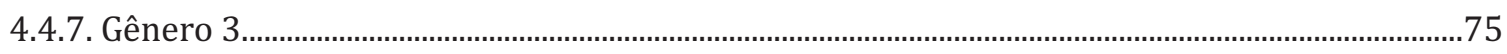

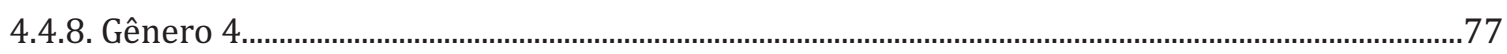

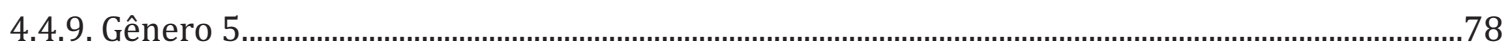

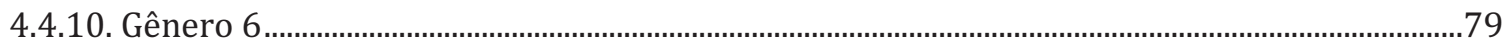

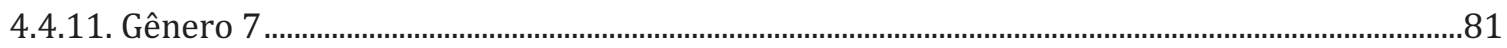

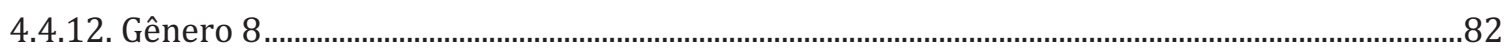

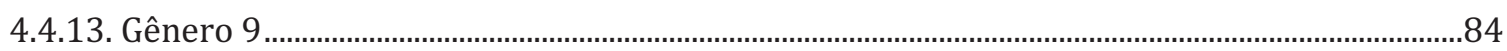

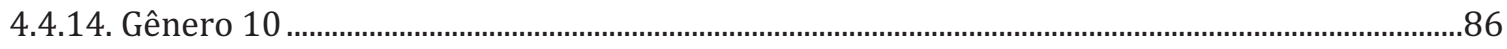

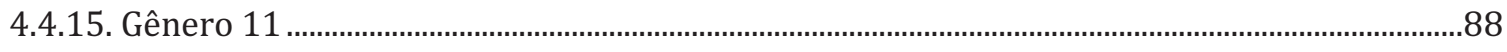

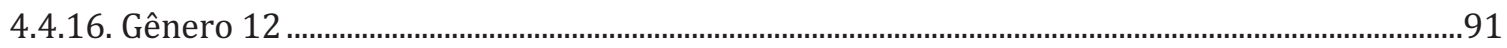

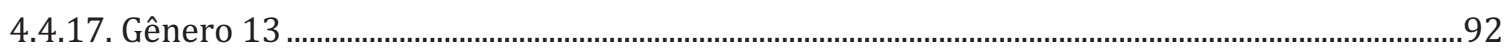

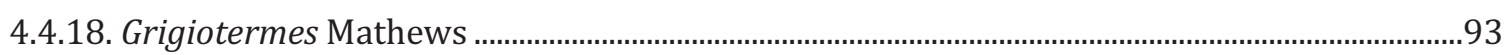

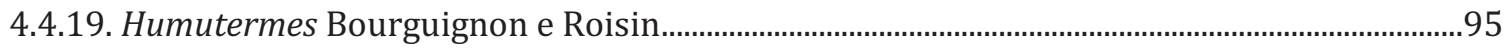

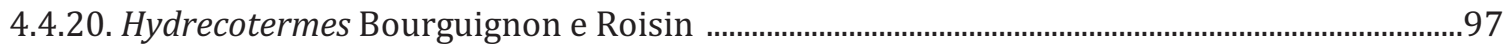

4.4.21. Longustitermes Bourguignon e Roisin ..................................................................................... 101

4.4.22. Patawatermes Bourguignon e Roisin .............................................................................................102

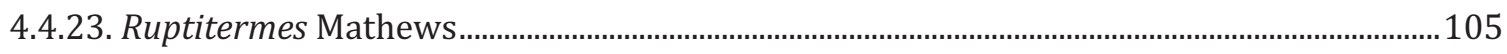

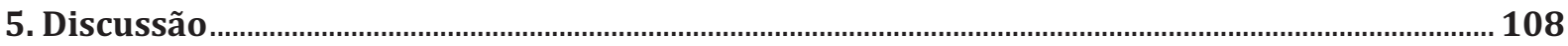

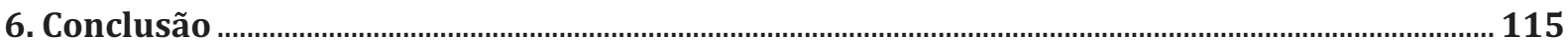

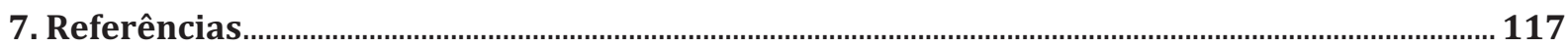

VOLUME II

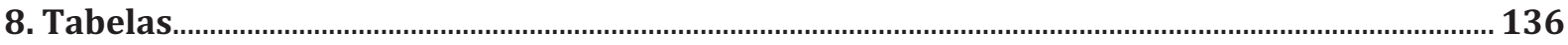

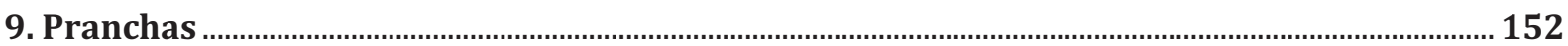





\section{INTRODUÇÃO}

Os cupins (Isoptera) são insetos hemimetábolos e eussociais, importantes econômica e ecologicamente, com 2958 espécies atuais conhecidas em 300 gêneros.

Embora sejam popularmente associados aos danos causados, com impactos bilionários nas áreas urbanas (Milano e Fontes, 2002; Lax e Osbrink, 2003; Kirton e Azmi, 2005; Rust e Su, 2012) e nas áreas rurais (Malik et al., 2015), apenas 12\% das espécies de cupim são reconhecidamente pragas (Krishna et al., 2013).

Em contraponto, a capacidade de digerir celulose (em parte, pela associação com simbiontes tanto no trato digestório, quanto no ninho) faz com que os cupins sejam protagonistas nos ecossistemas naturais, principalmente no que diz respeito ao papel que têm como decompositores (Holt e Lepage, 2000; Sugimoto et al., 2000). Além disso, a construção de ninhos e o tunelamento promovem a redistribuição de partículas, a drenagem e a aeração do solo, com um impacto positivo sobre a disponibilidade de nutrientes, o que por sua vez está associada à maior diversidade de microrganismos, flora e fauna (Wood e Sands, 1978; Brussaard, 1998; DeSouza e Cancello 2010; Jouquet et al. 2016). Todas estas ações no ambiente conferem a estes insetos o título de engenheiros de ecossistemas (Jones et al., 1994, Fox-Dobbs et al., 2010; Evans et al., 2011).

Blattaria (incluindo os cupins) e Mantodea formam o grupo Dictyoptera (Kristensen, 1981; Wheeler et al., 2001). As relações entre essas linhagens foram extensivamente discutidas ao longo dos últimos 20 anos (Deitz et al. 2003, Lo et al., 2003, Terry e Whiting, 2005, Klass e Meier, 2006; Inward et al., 2007a; Legendre et al., 2008, 2015) e hoje é consenso que os cupins são baratas sociais. Análises morfológicas e moleculares sustentam Isoptera como grupo-irmão das baratas do gênero Cryptocercus Scudder 1862 (Klass e Meier, 2006; Inward et al., 2007a; Klass et al., 2008; Djernæs et al., 2015). Os dois grupos compartilham características como a xilofagia, a simbiose com protozoários Hypermastigida e Oxymonadida, a transferência destes simbiontes entre gerações por trofalaxia anal e comportamento social (subssocialidade em Cryptocercus).

Há ainda alguma divergência em termos de classificação. Os cupins podem ser categorizados como epifamília (Termitoidae) da ordem Blattodea (Beccaloni e Eggleton, 2013) ou infraordem (Isoptera) da ordem Blattaria (Krishna et al., 2013), sendo esta última classificação a adotada neste trabalho. 
Não há consenso sobre a época de aparecimento dos cupins, com estimativas que variam do Triássico Médio entre 223 e 235 milhões de anos (Ma) (Ware et al., 2010); passando pelo Jurássico Superior entre 150 e 160 Ma (Engel et al., 2009; Legendre et al., 2015); até Cretácio inferior ao Jurássico Médio entre 136-170 Ma (Bourguignon et al., 2015). Os primeiros fósseis inquestionáveis datam do Cretáceo Inferior (110-135 Ma) e pertencem às famílias Mastotermitidae, Hodotermitidae, Kalotermitidae ou a famílias extintas (Krishna et al., 2013).

Os estudos mais abrangentes das relações filogenéticas em Isoptera foram os de Inward et al. (2007b) cuja análise utilizou 246 táxons, 40 caracteres morfológicos e três genes (12S rRNA, citocromo oxidase II (COII) e 28S rRNA); Legendre et al. (2008) com 54 táxons e 7 genes (12S rRNA, 16S rRNA, citocromo b (Cytb), citocromo oxidase I (COI), COII, 18S rRNA e 28S rRNA) e Bourguignon et al. (2015) que analisaram os genomas mitocondriais de 73 táxons. Nestas análises o grupo Isoptera é monofilético, bem como Kalotermitidae que permanece com posição incerta entre as famílias de cupins mais basais. Mastotermitidae é sempre o primeiro grupo a divergir. Os três estudos recuperam Archotermopsidae como parafilético com alguma divergência da relação entre esta família, Stolotermitidae e Hodotermitidae, as duas últimas monofiléticas. As maiores incertezas estão no status de Rhinotermitidae que aparece para- ou polifilética nas análises, e na posição de Serritermitidae. 0 monofiletismo de Termitidae é consistente nos trabalhos.

Das atuais nove famílias de Isoptera, a mais diversa é Termitidae com 2099 espécies atuais em 253 gêneros, compondo cerca de 70\% de todas as espécies conhecidas de cupim. Essa diversidade não se restringe apenas ao número de espécies, mas se aplica também aos grupos tróficos, arquitetura de ninhos e distribuição geográfica [presente em todas as regiões, exceto polos (Eggleton, 2000)].

O fóssil mais antigo da família Termitidae data de 50 Ma (Engel et al., 2011) com a maior abundância no registro fóssil em épocas mais recentes (cerca de $18 \mathrm{Ma}$ ) no âmbar da República Dominicana (Krishna e Grimaldi, 2009). Alguns resultados sugerem uma origem Etiópica ou Oriental pós Gondwana (Bourguignon et al., 2017) o que restringe a explicação para a atual distribuição geográfica à dispersão seguida de diversificação.

Termitidae compreende oito subfamílias: Apicotermitinae, Cubitermitinae, Foraminitermitinae, Macrotermitinae, Nasutitermitinae, Sphaerotermitinae, 
Syntermitinae e Termitinae (Krishna et al., 2013), propostas com base em caracteres de todas as castas, incluindo caracteres do tubo digestório (TD), em geral estudados nos operários (Noirot, 2001; Lo e Eggleton, 2011). Apesar de existir algum suporte para a relação (Macrotermitinae ((Foraminitermitinae, Sphaerotermitinae) (Apicotermitinae) (Termitinae+Cubitermitinae+Nasutitermitinae+Syntermitinae)) (Bitsch e Noirot, 2002; Inward et al., 2007b; Bourguignon et al., 2015), as relações internas em Termitidae ainda precisam de melhor resolução e permanecem sob discussão (Lo e Eggleton, 2011; Bourguignon et al., 2015). O maior problema se concentra em Termitinae que não é um grupo monofilético (Bitsch e Noirot, 2002; Inward et al., 2007b; Bourguignon et al., 2015).

A subfamília Apicotermitinae foi proposta por Grassé e Noirot (1955) e tem como gênero tipo Apicotermes Holmgren 1912. Está dividida em três subgrupos propostos por Noirot (2001) com base em caracteres do tubo digestório: “Grupo Anoplotermes" (Região Neotropical e Etiópica; soldados ausentes com exceção de Firmitermes Sjöstedt 1926); “Grupo Apicotermes" (Região Etiópica; soldados presentes exceto em Skatitermes Coaton 1971) e "Grupo Speculitermes" (Região Oriental; soldados presentes em baixa proporção). Com o avanço nos estudos taxonômicos, em especial para a região Neotropical (pouco conhecida e consequentemente pouco estudada por Noirot), e o desenvolvimento de uma filogenia para o grupo, provavelmente estes grupos não sejam sustentados (ver discussão sobre a filogenia de Inward 2007b, a seguir). São reconhecidas atualmente para a subfamília 217 espécies em 50 gêneros no mundo, e 52 espécies em 14 gêneros na região Neotropical.

Há registro fóssil de nove espécies do gênero Anoplotermes Müller 1873 no âmbar da República Dominicana que data do Mioceno (por volta de 17 Ma; Krishna e Grimaldi, 2009), sendo o posicionamento desses espécimes questionável, tanto na subfamília quanto no gênero, visto que não há nenhum caráter diagnóstico que o justifique. A origem dos Apicotermitinae é provavelmente etiópica com dispersão para a região Neotropical entre 29 e 34 Ma (Bourguignon et al., 2015; 2017).

Os trabalho de Inward et al. (2007b) e Bourguignon et al. (2017) recuperam a subfamília como monofilética, com os gêneros do "Grupo Apicotermes" na base e os gêneros do "Grupo Speculitermes" entre os gêneros do "Grupo Anoplotermes" (Fig.1). É interessante notar que um grupo com soldados presentes está na base da subfamília, sugerindo uma única perda desta casta. 
O estudo de caracteres morfológicos, principalmente dos relacionados ao tubo digestório, foram determinantes para o estabelecimento da subfamília. Grassé e Noirot (1955) apontam como alguns dos caracteres diagnósticos da subfamília os túbulos de Malpighi (com complexo ampuliforme), inseridos separadamente em uma região mesentérica anterior à junção com o íleo, e válvula entérica fortemente armada, destacando a importância da válvula entérica para identificação. Naquela publicação os autores reuniram sob a subfamília sete gêneros, todos pertencentes ao que chamamos de "Grupo Apicotermes": Allognathotermes Silvestri 1914, Apicotermes, Coxotermes Grassé e Noirot 1955, Heimitermes Grassé 1955 em Grassé e Noirot 1955, Hoplognathotermes Silvestri 1914, Jugositermes Emerson 1928 e Rostrotermes Grassé 1943.

Emerson (1959) discordando do status de subfamília proposto por Grassé e Noirot (1955) aloca os gêneros acima referidos (além dos descritos por ele próprio no artigo, hoje também em Apicotermitinae) em Termitinae salientando semelhanças ecológicas.

Sands (1972) defendeu a categorização de Apicotermitinae como subfamília como proposto por Grassé e Noirot (1955) e realizou um amplo trabalho de revisão das espécies africanas, do então gênero Anoplotermes, utilizando uma série de caracteres das mandíbulas, tubo digestório e caracteres morfométricos. Ao final da revisão ele descreveu ou redescreveu 60 espécies, sendo 51 delas espécies novas, em 16 gêneros, todos novos, reconhecendo o gênero Anoplotermes como exclusivamente neotropical. No catálogo de Snyder (1949) estão listadas 11 espécies etiópicas de Anoplotermes o que demonstra o grau de desconhecimento do grupo e a importância do trabalho de Sands (op.cit.).

Os gêneros de Apicotermitinae também já foram alocados em Amitermitinae (Snyder, 1949; Krishna, 1970) que posteriormente foi, em parte, incluída em Termitinae. Parte dos membros de Apicotermitinae também já foram reunidos sob 'Indotermitidae', nome não mais utilizado (Roonwal, 1958; Sands, 1972).

Sabe-se pouco sobre a forma de nidificação de Apicotermitinae. É conhecido que algumas espécies podem ser inquilinas de outros cupins ou nidificam de forma difusa no solo alimentando-se de matéria orgânica em decomposição (dados não publicados de observação de campo e comunicação com outros pesquisadores). Outras espécies constroem ninhos epígeos [p. ex. Anoplotermes pacificus Müller 1873 e Patawatermes 
turricola [Silvestri 1901)] e umas poucas constroem ninhos arborícolas (p. ex. Ruptitermes arboreus (Emerson 1925) e Anoplotermes banksi Emerson 1925). Vários trabalhos destacam a complexidade dos ninhos subterrâneos bem definidos de Apicotermes (Grassé e Noirot, 1955; Desneaux, 1956; Noirot, 1970).

No que diz respeito às relações tróficas, os Apicotermitinae são geralmente categorizados como humívoros (Krishna et al., 2013), mas o gênero Ruptitermes Mathews 1977 aparece classificado em diversos estudos de comunidade como ceifadores ou consumidores de madeira em decomposição (p. ex. Oliveira et al., 2013; Couto et al., 2014; Cancello et al., 2014), além de haver uma série de registros de campo (incluindo filmagens) que reportam esses cupins cortando grama (Eliana Cancello, comunicação pessoal). Algumas morfoespécies de Apicotermitinae aparecem nesses trabalhos em outros grupos tróficos que não o dos humívoros (Gontijo e Domingos, 1991; Constantino, 1992). Nos ninhos de Eurytermes Wasmann 1902 foram observados jardins de fungos (Roonwal, 1970a) e Kaiser (1953) levanta a hipótese de que Anoplotermes pacificus consuma raízes dentro do ninho. De fato, conhece-se muito pouco sobre os hábitos alimentares desses cupins.

Os soldados estão presentes em 40\% dos gêneros descritos de Apicotermitinae e lembram os soldados de Termitinae, são mandibulados com uma glândula frontal fracamente desenvolvida (exceto Coxotermes). No "Grupo Speculitermes" a proporção de soldados é muito baixa. Roonwal e Chhotani $(1960,1966)$ registram uma proporção entre 0,20-0,44\% de soldados na colônia de Speculitermes sinhalensis Roonwal e SenSarma 1960.

Nos grupos sem soldados os operários desenvolveram algumas formas de defesa, como a ruptura do abdômen expondo o produto, muitas vezes pegajoso, de órgãos deiscentes (Poiani e Costa-Leonardo, 2016) ou o próprio conteúdo intestinal (gastrotomia reflexa (tradução livre); Sands, 1972) e o depósito de fluidos fecais no organismo antagonista (Coaton, 1971; Grassé, 1986).

Uma explicação para a perda do soldado ao longo da evolução do grupo pode ser dada pela redução do valor do custo/benefício na produção de soldados. A presença desta casta é vantajosa quando ocorre uma alta taxa de sobrevivência de indivíduos da colônia em relação à perda de um soldado. A ausência do soldado pode ocorrer então pela ineficiência na defesa ou uma diminuição na pressão de predação (Higashi et al., 
2000), o que poderia ser explicado pelo hábito subterrâneo e de inquilino dentro de ninhos muito protegidos.

Os Apicotermitinae representam o maior problema taxonômico de Isoptera (Kambhampati e Eggleton 2000; Eggleton, 1999, 2000; Constantino, 2005; Inward, 2007b, Bourguignon et al., 2010). De acordo com Constantino (1999) é esperado resultado semelhante ao encontrado por Sands (1972) na África, quando a fauna Neotropical for estudada.

Essa falta de resolução se deve ao fato da maior parte das espécies não contarem com a casta de soldados, que concentra boa parte das características externas normalmente usadas para identificação. Para a casta do operário, a identificação em nível específico requer estudo do enrolamento e dissecção do tubo digestório para verificação da válvula entérica, inserção de túbulos de Malpighi, e moela, atividade que requer maior tempo e treinamento. As primeiras descrições das espécies da subfamília foram feitas a partir da casta do alado, o que hoje gera um grande problema para a identificação, tanto a partir das publicações quanto dos espécimes tipo. Um problema recorrente no estudo da subfamília é o número de amostras sem alados ou de alados sem operários, sendo difícil a associação dos operários com seus respectivos alados (Scheffrahn, 2013), e limitando a utilização de caracteres dessa casta.

Estudos com diversidade de espécies na África apontam que os Apicotermitinae representam de 30 a 40 por cento do total dos cupins amostrados (Eggleton et al., 1996; Kambhampati e Eggleton, 2000). Dados semelhantes foram encontrados para a região do Alto Madeira em Rondônia (Carrijo, 2013) onde os Apicotermitinae foram o grupo mais abundante e o segundo mais diverso, com 37 morfoespécies (32\% do total) e abundância relativa de 37\% do total. Davies et al. (2003), na Guiana Francesa, encontraram uma composição de cupins com 34\% das espécies identificadas como Apicotermitinae. Números similares para a proporção de Apicotermitinae também foram encontrados na Amazônia por Ackerman et al. (2009) com 30\%, Bourguignon et al. (2011) com 35\%, e Palin et al. (2011) com 50\% das espécies amostradas pertencentes a essa subfamília. O mesmo foi verificado por Cancello (1994) em levantamento de cupins em áreas do Nordeste brasileiro, em que foram identificadas 138 morfoespécies, sendo 48 de Apicotermitinae.

No entanto, devido a sua taxonomia obscura, é possível que os números de diversidade sejam ainda maiores (Eggleton, 1994; Cunha et al., 2006; Oliveira et al., 
2013). Os dados de riqueza e abundância para Apicotermitinae ilustram sua importância ecológica nestes ambientes.

\subsection{Histórico Taxonômico dos Apicotermitinae da Região Neotropical}

Os membros do "Grupo Anoplotermes", representantes de Apicotermitinae na Região Neotropical, e objeto de estudo deste trabalho, são caracterizados pela perda do soldado, característica que compartilham com Invasitermes Miller 1984, Orientotermes Ahmad 1976 e Protohamitermes Holmgren 1912, três gêneros da subfamília Termitinae que não ocorrem na Região Neotropical. Sem as características do soldado, neste grupo o tubo digestório tem papel fundamental na taxonomia (Grassé e Noirot, 1955; Sands, 1972).

Dos 14 gêneros (tratados a seguir) presentes na região Neotropical nove foram descritos nos últimos nove anos, após 30 anos sem trabalhos taxonômicos com o grupo.

0 primeiro gênero neotropical de Apicotermitinae a ser descrito foi o gênero Anoplotermes baseado em observações de campo e descrição do ninho (Müller, 1873). Durante muito tempo todas as espécies de cupins sem soldados (inclusive as de outras regiões biogeográficas) foram alocados nesse gênero, com descrições baseadas somente na morfologia externa do alado, sendo pouco informativas e gerando erros e dúvidas na identificação das espécies.

Em Bourguignon et al. (2010) foi iniciada a revisão do gênero Anoplotermes na qual foram redescritas as espécies Anoplotermes pacificus, Anoplotermes banksi e Anoplotermes parvus Snyder 1923; foi descrita uma nova espécie, Anoplotermes janus Bourguignon e Roisin 2010, em Bourguignon et al. 2010; estabeleceram novos sinônimos juniores (Anoplotermes indistinctus Snyder 1926 sinônimo júnior de Anoplotermes pacificus; Anoplotermes brevipilus Emerson 1925, Anoplotermes clypeatus Snyder 1926, Anoplotermes distinctus Snyder 1926 e Anoplotermes proximus Snyder 1926 sinônimos juniores de Anoplotermes parvus); erigiram um novo gênero, Longustitermes Bourguignon e Roisin 2010, em Bourguignon et al. 2010, com uma nova combinação Longustitermes manni (Snyder 1922) e também um novo sinônimo júnior (Anoplotermes linearis Snyder 1926) para esta espécie.

Apesar do esforço, ainda restam 16 espécies dentro do gênero Anoplotermes que não podem ser identificadas através das publicações originais, e precisam de revisão: Anoplotermes ater (Hagen 1858), Anoplotermes bolivianus Snyder 1926, Anoplotermes 
brucei Snyder 1955, Anoplotermes distans Snyder 1926, Anoplotermes fumosus (Hagen 1860), único Apicotermitinae conhecido da região neártica, Anoplotermes gracilis Snyder 1922, Anoplotermes grandifons Snyder 1926, Anoplotermes hondurensis Snyder 1924, Anoplotermes howardi Snyder 1926, Anoplotermes meridianus Emerson 1925, Anoplotermes punctatus Snyder 1926, Anoplotermes pyriformis Snyder 1934, Anoplotermes rotundus Snyder 1926, Anoplotermes schwarzi Banks 1919, Anoplotermes subterraneus Emerson 1925 e Anoplotermes tenebrosus (Hagen 1858).

No catálago de Krishna et al. (2013) está listada a espécie Anoplotermes burmeisteri (Czerwinski 1901), no entanto, Constantino (2018) após investigação sobre a identidade do material estudado por Czerwinski, determinou que Anoplotermes burmeisteri é sinônimo júnior de Cortaritermes fulviceps (Silvestri 1901).

Em seu trabalho sobre cupins do Mato Grosso, Mathews (1977) descreveu dois novos gêneros de Apicotermitinae: Grigiotermes e Ruptitermes. 0 gênero Grigiotermes é bem caracterizado pelas seis placas com espinhos projetadas externamente (na luz da pança) a partir da válvula entérica. Já o gênero Ruptitermes é bastante característico pela presença de órgãos deiscentes que ocupam o tórax e parte do abdômen, órgão que desempenha papel de defesa, pois libera uma substância pegajosa após o rompimento da parede do corpo do cupim. Ambos os gêneros foram recentemente revisados.

Bourguignon et al. (2016a) redescrevem Grigiotermes sinonimizando a espécie Grigiotermes metoecus Mathews, 1977 (espécie tipo por designação original e sinônimo júnior) com Anoplotermes hageni Snyder e Emerson 1949 em Snyder, 1949 (sinônimo sênior) além de estabelecer um novo gênero, Patawatermes Bourguignon e Roisin 2016 em Bourguignon et al. 2016a, com duas novas combinações: Patawatermes turricola (Silvestri 1901) (sinônimo sênior de Anoplotermes bequaerti Snyder e Emerson 1949 em Snyder, 1949) e Patawatermes nigripunctatus (Emerson 1925) (que estava antes em Anoplotermes). Também no trabalho de revisão de Grigiotermes (Bourguignon et al., 2016a) foram descritos os gêneros Amplucrutermes, Humutermes, Hydrecotermes, e Rubeotermes, os três primeiros morfologicamente próximos à Anoplotermes e com diagnóstico baseado primariamente na válvula entérica.

Acioli e Constantino (2015) trabalharam em uma ampla revisão de Ruptitermes, melhorando sua diagnose e definindo 13 espécies para o gênero, sendo nove espécies novas [Ruptitermes araujoi Acioli e Constantino 2015, Ruptitermes arboreus (Emerson 1925), Ruptitermes atyra Acioli e Constantino 2015, Ruptitermes bandeirai Acioli e 
Constantino 2015, Ruptiternes cangua Acioli e Constantino 2015, Ruptitermes franciscoi (Snyder 1959), Ruptitermes kaapora Acioli e Constantino 2015, Ruptitermes krishnai Acioli e Constantino 2015, Ruptitermes maraca Acioli e Constantino 2015, Ruptitermes piliceps Acioli e Constantino 2015, Ruptitermes pitan Acioli e Constantino 2015, Ruptitermes reconditus (Silvestri 1901), Ruptitermes xanthochiton Mathews, 1977 (espécie tipo por designação original)].

Dois gêneros foram estabelecidos por Fontes (1986), um deles, Tetimatermes Fontes 1986 (com Tetimatermes oliveirae Fontes 1986 como espécie tipo por designação original), muito característico pela tíbia anterior do operário ser em forma de colher, e Aparatermes Fontes 1986, bastante controverso na sua identidade, pois foi designado a partir da subespécie Anoplotermes cingulatus abbreviatus Silvestri 1901, que já no trabalho original tem uma caracterização frágil, baseada em medidas do alado. Fontes (1986) não inclui Anoplotermes cingulatus (Burmeister 1839) espécie na qual Silvestri (1901) se baseia, só o fazendo posteriormente (Fontes, 1998), mas sem redescrição ou caracterização.

Mais recentemente, Scheffrahn $(2013 ;$ 2017) descreveu dois novos gêneros: Compositermes Scheffrahn 2013, que possui uma estrutura única localizada no final do assentamento da válvula entérica, um conjunto de placas armadas com espinhos; e Disjunctitermes Scheffrahn 2017, em Scheffrahn et al. 2017, um gênero próximo morfologicamente de Anoplotermes, diagnosticado com base em caracteres da mandíbula do operário e da válvula entérica.

Por fim, foi publicado o gênero Echinotermes Castro e Scheffrahn 2018, em Castro et al. (2018) baseado em caracteres da válvula entérica.

É bastante claro o viés do uso da válvula entérica para o estabelecimento de novas espécies e novos gêneros. Associada a algumas das novas descrições há também o uso do DNA barcode (COI), que tem pouca resolução para agrupamentos supraespecíficos, com suportes muito baixos, sendo pouco informativo considerando-se que nestes trabalhos as características morfológicas são suficientes para a separação das espécies. 


\subsection{Justificativa para o recorte adotado neste trabalho}

A escolha da Mata Atlântica como recorte deste projeto não é de forma alguma aleatória. Ao passo que a Mata Atlântica é considerada um hotspot da biodiversidade global, com altas taxas de endemismo (Myers et al., 2000), é também o ecossistema brasileiro mais ameaçado (Ribeiro et al., 2009; Oliveira-Filho e Fontes, 2000). A Mata Atlântica originalmente se estendia entre as latitudes $6^{\circ}$ e $30^{\circ} \mathrm{Sul}$, ao longo de 17 estados brasileiros, em uma área estimada em 1,3 milhões de $\mathrm{km}^{2}$. Destes, restam entre 7,5\% a 12\% variando de acordo com a estimativa (Morellato e Haddad, 2000; Myers et al., 2000; Ribeiro et al., 2011).

Considerando tudo isso, a Mata Atlântica tem sido alvo de projetos conservacionistas que resultaram em estudos na área ao longo das últimas décadas (p. ex. Galindo-Leal e De Gusmão Câmara, 2005). Alguns estudos da biodiversidade da Mata Atlântica foram conduzidos no Museu de Zoologia da USP (MZUSP).

No MZUSP estão depositadas cerca de 6700 amostras de Apicotermitinae principalmente de localidades brasileiras, mas contendo também material de outros países da Região Neotropical, e pouco de outras regiões. Entre essas amostras há ainda tipos como, por exemplo, os holótipos de Grigiotermes meteocus, Ruptitermes bandeirai, Ruptitermes xanthochiton e Tetimatermes oliveirae, e parátipos de boa parte dos demais Apicotermitinae neotropicais.

Um grande volume desse material é oriundo do projeto temático do Programa Biota/FAPESP: "Biodiversidade de Riqueza e diversidade de Hymenoptera e Isoptera ao longo de um gradiente latitudinal na Mata Atlântica" (Proc. 98/0583-0), desenvolvido entre 1/02/2000 e 01/03/2005, e cujo coordenador foi o Prof. Carlos Roberto F. Brandão. A Profa. Eliana Cancello foi responsável pela parte dos Isoptera do projeto, desde a proposta do desenho amostral até a identificação final de todo o material, totalizando cerca de 2000 amostras.

Neste projeto investigaram-se 15 localidades regularmente espaçadas desde João Pessoa, Paraíba, até Blumenau, Santa Catarina, totalizando 727 amostras de cupins das coletas quantitativas, sendo identificadas 87 morfoespécies, das quais metade representam táxons não descritos (Cancello et al., 2014). Para Apicotermitinae, 20 morfoespécies foram identificadas, podendo ser nomeada apenas a espécie Anoplotermes pacificus, e oito das morfoespécies não puderam ser associadas a nenhum 
dos gêneros descritos para a região Neotropical na época em que as amostras foram identificadas.

Outra parte das amostras do mesmo bioma foi coletada durante o trabalho de Schlemmermeyer (2000), que realizou um levantamento da termitofauna da Estação Biológica de Boracéia, totalizando 322 amostras de cupins coletadas, sendo 116 da subfamília Apicotermitinae. Dois gêneros não descritos foram indicados, além de uma espécie não descrita de Aparatermes e outra de Anoplotermes (Schlemmermeyer, 2000).

Há ainda um volume considerável de material do sul da Bahia, proveniente das coletas realizadas pela ex-aluna da Profa. Eliana Cancello, Yana Reis (Reis, 2007), que teve como objetivo comparar a riqueza de cupins em áreas de floresta ombrófila densa, mesófila de altitude e mata-de-cipó de altitude. Entre as amostras estão duas espécies que foram identificadas como Anoplotermes sp. e uma morfoespécie de Apicotermitinae que não pode ser incluída em nenhum gênero (Reis, op. cit.).

Concomitante à proposição e desenvolvimento desse projeto estavam previstas coletas associadas ao projeto Fapesp 2013/20068-9 (Análises filogeográficas de duas espécies de cupins (Isoptera) Neotropicais com diferentes biologias), que também contemplaram áreas de Mata Atlântica.

Além das coletas descritas, há uma grande quantidade de material coletado por Renato L. Araujo durante seu período de curadoria da coleção de Isoptera do Museu de Zoologia, principalmente na porção sul da Mata Atlântica, com uma série de notas detalhadas sobre a biologia, e um número pouco representativo de outros coletores.

Todo o material descrito acima está depositado no Museu de Zoologia e reúne uma valiosa fonte de investigação da variação e diversidade de cupins na Mata Atlântica. Além do mais, pela dificuldade taxonômica já citada, o material coletado de Apicotermitinae acaba por ser subutilizado, e estudar as amostras coletadas nos projetos supracitados é uma forma de otimizar os investimentos recebidos e gerar mais informação.

Para estudar este complexo grupo, colaborando para sua compreensão na região Neotropical, evitando sobreposições com os laboratórios que também estão trabalhando com a mesma subfamília, e viabilizando a pesquisa no tempo estipulado para o doutorado, mostrou-se conveniente um recorte dentro de um bioma brasileiro.

Definiu-se então a partir de todo o material disponível e da importância da Mata Atlântica, um recorte para a condução de um trabalho que contribuísse com um olhar 
comparativo, praticamente inédito no estudo dos Apicotermitinae neotropicais, e também pudesse ajudar na curadoria especializada de uma parte significativa da coleção de Isoptera do Museu de Zoologia.

As amostras selecionadas para este trabalho concentram-se principalmente nas áreas de Mata Atlântica denominadas "florestas úmidas" ("wet forests") e minoritariamente em áreas de "floresta semidecídua" ("semideciduous forest", ambos termos sensu Neves et al. 2017).

Pela novidade da abordagem é importante ressaltar que esse não é um trabalho com enfoque ecológico, embora possa contribuir significativamente para os avanços na área. Também não é uma revisão da subfamília, tarefa impossível de se realizar por um pesquisador no espaço de tempo de um doutoramento (ou da vida?!). Também não é a revisão de um gênero ou grupos de gêneros. Este é um trabalho essencialmente taxonômico, que busca estudar a identidade de várias espécies e propor agrupamentos. 


\section{OBJETIVOS}

Este trabalho teve como objetivo estudar o material de Apicotermitinae (Termitidae) da Mata Atlântica depositado no Museu de Zoologia da Universidade de São Paulo, identificando os táxons através do estudo comparativo da morfologia externa e interna de operários, e externa de alados, investigando características pouco estudadas que possam ser informativas na taxonomia do grupo.

Para isso, o material foi ilustrado, os registros dos táxons foram mapeados, foram feitas redescrições de espécies e gêneros descritos, e descrições de espécies e gêneros ainda não conhecidos, além de ter sido realizado estudo morfométrico. Também, foram estudados os tipos disponíveis e realizadas comparações com os demais Apicotermitinae neotropicais, com o que foi possível desenvolver uma chave de identificação preliminar para estas espécies ou grupos de espécies. 


\section{MATERIAL E MÉTODOS}

\subsection{Lista de Acrônimos das instituições citadas}

Os acrônimos das instituições citadas neste estudo são: AMNH-American Museum of Natural History, Nova Iorque, Estados Unidos; BMNH - The Natural History Museum, Londres, Reino Unido; CMNH-Chicago Museum of Natural History, Chicago, Illinois, Estados Unidos; FTLD-University of Florida, Fort Lauderdale Research and Education Center, Davie, Flórida, Estados Unidos; IFML-Instituto-Fundación Miguel Lillo, Tucumán, Argentina; MCZ-Museum of Comparative Zoology, Harvard University, Cambridge, Massachusetts, Estados Unidos; MLU-Martin Luther Universität, HalleWittenberg, Alemanha; MZUSP_Museu de Zoologia da Universidade de São Paulo, São Paulo, Brasil; NHMW-Naturhistorisches Museum, Viena, Áustria; RIB-Institut Royal des Sciences Naturelles de Belgique, Bruxelas, Bélgica; NHRM-Naturhistoriska Riksmuseet, Estocolmo, Suécia; UFABC-Universidade Federal do ABC, São Bernardo do Campo, São Paulo, Brasil; UnB-Universidade de Brasília, Brasília, Distrito Federal, Brasil; USNM - Smithsonian National Museum of Natural History, Washington DC, Estados Unidos; ZMB-Museum für Naturkunde an der Universität Humbolt zu Berlin, Berlim, Alemanha.

\subsection{Material Depositado no Museu de Zoologia da USP}

Foi realizado o levantamento de todas as amostras de Apicotermitinae depositadas no MZUSP, seguida pela seleção das amostras das localidades de Mata Atlântica, como já discutido. 0 total foi de 546 amostras de Apicotermitinae. Além dessas amostras, estão depositadas no Museu de Zoologia e foram usadas como material de referência os holótipos de Grigiotermes meteocus Mathews 1977, Ruptitermes bandeirai Acioli e Constantino 2015, Ruptitermes xantochiton Mathews 1977, Tetimatermes oliveirae Fontes 1986 e o parátipo de Ruptitermes pitan Acioli e Constantino 2015.

\subsection{Material Coletado para o projeto}

A partir da análise do material selecionado das amostras depositadas no Museu de Zoologia foram identificadas áreas sem amostragem na Bahia e no Espírito Santo.

Além de aumentar o registro nas áreas subamostradas, o interesse em realizar uma nova coleta e aumentar o número de amostras, mesmo tendo em vista toda a 
complexidade da proposta de trabalho sem esse esforço adicional, recai sobre a importância da coleta focada nos Apicotermitinae, e que pudesse oferecer tanto dados de biologia, quanto amostras armazenadas de forma adequada para a condução de futuros trabalhos usando biologia molecular.

Foram coletadas 208 amostras das quais 54 amostras são de Apicotermitinae.

\subsection{Visita à coleção de Isoptera do Americam Museum of Natural History}

A maior parte das espécies do gênero Anoplotermes não revisitadas pelo trabalho Bourguignon et al. (2010), foi descrita por Snyder (1926, 1934, 1955) e estão depositadas no Smithsonian Natural History Museum e American Museum of Natural History. Foi combinada com os curadores das duas coleções a estadia de um mês no AMNH com empréstimo dos espécimes do USNM. Infelizmente o material separado pelo curador do USNM não correspondeu aos tipos previamente solicitados. Não foi possível estabelecer a identidade das espécies descritas por Snyder cujos tipos não estavam em duplicatas no AMNH.

\subsection{Material de empréstimo e doação}

Foram solicitadas amostras de Disjunctitermes ao Dr. Rudolf Scheffrahn, da Universidade da Flórida, e amostras das espécies novas descritas por Bourguignon et al. (2016a) ao Dr. Yves Roisin da Universidade de Bruxelas.

Aproveitando a visita de Carolina Cuezzo, então pós-doutoranda supervisionada pela Profa. Eliana Cancello, ao CMNH, foram solicitados os tipos de Anoplotermes banksi e Aparatermes silvestrii. Material fotográfico de alguns tipos de interesse do material do AMNH e do MCZ foi compartilhado pelo Prof. Reginaldo Constantino da UnB. O material seco (alados) depositado no MCZ está em condições muito ruins de conservação, impossibilitando a identificação. Foi compartilhado pelo Prof. Tiago Carrijo material fotográfico do tipo de Anoplotermes jheringi Holmgren 1906, depositado no NHRM.

A tabela 1 apresenta o total de amostras estudadas neste trabalho.

\subsection{Estudo da morfologia externa e interna}

A tabela 2 reúne os caracteres morfológicos tradicionalmente utilizados em trabalhos taxonômicos com a subfamília Apicotermitinae para o estudo e delimitação das espécies e utilizadas neste estudo. 
As amostras foram analisadas sob estereomicroscópio, alinhando os operários em uma placa de Petri com álcool gel para melhor posicioná-los e compará-los. Um espelho foi usado sob a placa para auxiliar o estudo da pilosidade.

\section{Morfologia externa}

Nos alados, existem duas manchas mais claras entre o pós-clípeo e os ocelos que são referidas na literatura como 'muscle insertions' (Emerson, 1925), 'spots' (Mathews, 1977) ou 'frontal marks' (Acioli e Constantino, 2015). Aqui será padronizado o uso de "manchas frontais".

Na região entre os ocelos, à frente da fontanela, existe uma mancha pouco conspícua na maior parte dos espécimes, mas conspícua nos alados de Anoplotermes referida por Mathews (1977) como 'medial frons spot' que seria a inserção do músculo mediano do labro (Grassé, 1892). Será usado aqui o termo "mancha mediana".

A rigor, o que é referido como "fontanela" é a abertura da glândula frontal em soldados (Šobotník et al. 2010). No entanto, este nome também se refere à região esbranquiçada no vértice da cápsula cefálica em operários e alados. As diferenças dessa região entre as diferentes castas foram relatadas na literatura (Banks, 1920, p. 2; Weesner, 1969, p. 25), e alguns autores a denominaram como "middorsal spot" em operários e alados (Torre-Bueno, 1989, p.452; Weesner 1969, p. 31). Nos trabalhos clássicos, no entanto, como Grassé (1982, p.27), usa-se o termo fontanela para todas as castas. Neste trabalho será definida como "fontanela” a mancha no vértice da cápsula cefálica de alados e operários, associada à glândula frontal, mesmo que não haja uma abertura propriamente. A adoção de uma nova terminologia pode ocorrer no futuro, se novos estudos corroborarem a homoplasia dessas estruturas em diferentes castas (ou seja, estudos embriológicos e / ou de expressão gênica).

A variação no pós-clípeo foi considerada tendo como referência a margem superior da cabeça em perfil podendo ser inflado, fortemente inflado ou não inflado. Não é uma característica facilmente visível nas imagens fornecidas aqui, mas os extremos (em especial quando o pós-clípeo é fortemente inflado) colabora para a separação das espécies em exames comparativos.

Foram realizados testes para o uso da microscopia de varredura (MEV). A metodologia de ponto crítico foi substituída pela preparação das amostras por banhos de hexametildisilazane (Nation, 1983). As estruturas selecionadas para o teste foram 
cabeça, pernas e peças bucais, a fim de analisar o potencial informativo de cada uma delas, explorando a existência de ornamentação e apresentação da pilosidade. Alguns destes testes foram realizados no Laboratório Multiusuário do MZUSP e também no Laboratório Multiusuário da UFABC campus São Bernardo do Campo, utilizando o Microscópio Eletrônico de Varredura FEI Quanta 250.

Houve grande dificuldade em ajustar a técnica, além da dificuldade no uso do aparelho de microscopia de varredura [agendamento, defeito sucessivo nos filamentos (MEV-MZUSP), manipulação]. Foram feitos avanços para o tratamento dos alados, mas sem sucesso para os operários.

Para pilosidade da cabeça o uso dos termos é sempre comparativo. A tabela 3 foi elaborada para uniformizar a nomenclatura.

As mandíbulas de alados e operários foram estudadas comparativamente e fotografadas usando como referência os trabalhos de Sands (1972) e Deligne (1999). Em Sands (1972, fig. 2) é representada uma variação do dente que ele denomina como 'subsidiário marginal', que pode estar oculta ou não pela proeminência molar dependendo da posição que ocupa, e indica que o estado deste dente é uma boa característica genérica. 0 mesmo dente é chamado por Deligne (1999) de pré-molar e por Krishna (1968) de molar. Tradicionalmente o termo "subsidiário" é utilizado para designar a estrutura presente na base do dente apical na mandíbula esquerda ou direita em algumas famílias não Termitidae, o que poderia gerar algum ruído na literatura. Além disso, foi observado na mandíbula esquerda dos alados outro processo não referido na literatura, mais próximo do M3. Portanto, propõe-se o uso de "processo prémolar" para a estrutura mais próxima do M3 e "processo molar" para a estrutrura mais próxima da proeminência molar, frisando que ambos os processos fazem parte da região molar. As figuras 2-4 apresentam legendas para referência.

As tíbias anteriores foram categorizadas de acordo com o índice da tíbia (ver abaixo, no item Morfometria, como o índice foi calculado): fortemente infladas (média do índice da tíbia acima de 0,25), infladas (média do índice da tíbia entre 0,25 e 0,20) e não infladas (média do índice da tíbia abaixo de 0,19).

\section{Morfologia interna}

Muitas das espécies estudadas apresentaram, in vivo ou fixadas em álcool, estruturas esbranquiçadas, de formato variável, que ocupavam a região do tórax e os 
primeiros segmentos abdominais (denominado aqui de região toraco-abdominal). Tradicionalmente estruturas com estas características foram associadas às espécies do gênero Ruptitermes, tornando-se característica diagnóstica do gênero (Acioli e Constantino, 2015), e mais recentemente, por apresentarem arranjo histológico diferente daquele observado em glândulas, foi denominada como "órgãos deiscentes" (Poiani e Costa-Leonardo, 2016). Será usado ao longo deste trabalho o termo "órgão deiscente" de forma generalizada para todos os espécimes que exibiram estruturas semelhantes, embora haja diversidade de formato, cor e forma de deiscência dessa estrutura nas espécies consideradas, não descritas, havendo a necessidade de estudos histológicos que confirmem a sua natureza.

Foi adotada para o estudo do tubo digestório a nomenclatura proposta por Noirot (2001). Como Noirot usa tanto termos por extenso quanto siglas, optou-se aqui pelos termos por extenso: papo, moela, mesêntero, segmento misto, íleo, válvula entérica, assentamento da válvula entérica, pança, colo e reto. A figura 5 apresenta um esquema de referência para estas estruturas. Será usada como tradução livre de "enteric valve seating" a expressão "assentamento da válvula entérica". Foram estudados o padrão de enrolamento do tubo digestório, as características do segmento misto, calibre e extensão do íleo e ornamentação da válvula entérica.

As indicações de orientação para descrição do tubo digestório seguem o seguinte: a parte proximal de uma estrutura interna (p. ex. da válvula entérica) é aquela que fica mais próxima da abertura oral, ou seja, mais próximo do íleo no caso da válvula entérica, e a distal é aquela que fica mais próxima da região anal, no caso da válvula entérica, próximo da pança, tomando como referência o tubo digestório estendido (não enrolado). Nas imagens de válvula entérica (inteiras e detalhe), a parte superior da imagem corresponde à região mais próxima da pança e a parte inferior da imagem à região mais próxima ao íleo.

0 estudo do enrolamento do tubo digestório in situ foi realizado de forma semelhante ao da morfologia externa, uma vez que é possível reconhecer as regiões do tubo por transparência.

O segmento misto é definido como uma região entre o mesêntero e o íleo, onde são encontrados os dois tecidos. 0 segmento misto foi considerado ausente quando o mesêntero termina de forma abrupta sem nenhuma projeção sobre o íleo; vestigial quando há uma porção levemente oblíqua, mas que não forma uma lingueta 
propriamente dita; e presente quando claramente é possível distinguir uma lingueta mesentérica, que pode ser globosa ou não.

A lingueta mesentérica foi definida como inflada quando termina em uma estrutura globulosa, ou não inflada quando não há estrutura globulosa.

O íleo foi classificado em relação a sua extensão, considerando a região de encontro com o assentamento da válvula entérica. 0 íleo pode terminar ventralmente, na lateral direita ou dorsalmente.

Para o assentamento da válvula entérica foram considerados os estados tubular, em que a região aparece como um tubo de extensão variável (curto ou longo) que se separa da primeira porção da pança por uma região de constrição, e trilobado, em que claramente há duas porções globulares visíveis in situ (estando a terceira porção oculta), seguidas pela região de constrição. 0 grau de repleção do tubo digestório pode afetar o diagnóstico.

Nos Apicotermitinae a válvula entérica encontrou o ápice de sua diversificação (Figs. 6-7), e em alguns casos se encontra invaginada na pança, com uma porção armada quitinosa extrovertida, característica exclusiva da subfamília (Noirot e Noirot-Timothée, 1969). É possível definir duas regiões para o estudo da válvula entérica, sendo a primeira a face interna do tubo, onde estão as seis pregas, que nos Apicotermitinae neotropicais nunca apresentam ornamentação quitinosa fortemente esclerotizada, como ocorre em outros membros da família Termitidae e mesmo em alguns Apicotermitinae etiópicos (p. ex. Allognathotermes Silvestri 1914, Heimitermes Grassé 1955 em Grassé e Noirot, 1955, Coxotermes Grassé e Noirot 1955, Machadotermes Weidner 1974); e a segunda região da válvula entérica, a região extrovertida, em geral fortemente esclerotizada. Mesmo entre espécies com válvula entérica inerme (não armadas) e válvula entérica armada, as pregas na face interna podem ser comparáveis (p. ex. as espécies em Anoplotermes). A válvula entérica foi definida como inerme ou armada, considerando que uma válvula entérica é armada quando há porção esclerotizada extrovertida na luz da pança. Pode ser fracamente armada quando existe uma porção extrovertida, mas é pouco desenvolvida; e fortemente armada quando a porção extrovertida é muito desenvolvida.

A dissecção da moela, íleo e válvula entérica se deu sob lupa em uma placa de Petri com álcool 80\%, na qual a parede abdominal externa do espécime era retirada com o auxílio de estiletes com ponta fina, seguida de corte da porção do tubo digestório que 
contém a válvula entérica (porção final do íleo e porção inicial da pança). Com batidas leves o conteúdo intestinal era retirado de modo a restar apenas o epitélio e musculatura da porção extirpada. Pressionando a peça no fundo da placa com movimentos de rolamento é esperado que a musculatura externa se soltasse da peça restando apenas o epitélio.

Após a limpeza da peça, o tubo foi cortado para ser montado em PVA (álcool polivinílico; Salmon, 1951), meio de montagem semi-permanente, de forma que as peças fossem preservadas para repetidas consultas durante o trabalho. 0 uso do PVA para este fim é relativamente novo e ainda está sob avaliação em relação ao tempo de conservação. A montagem usando o PVA tem a vantagem de ser muito mais rápida que os meios de montagem convencionais (p. ex. Hoyer, Bálsamo do Canadá). Cada válvula entérica estudada levou entre 30 a 50 minutos para ser montada. Foram montadas cerca de 600 lâminas, etiquetadas com o número de tombo da amostra de origem, localidade.

\subsection{Morfometria}

As medidas foram tomadas sob estereomicroscópio com ocular micrométrica e os insetos imersos em álcool com areia fina como substrato para o melhor posicionamento. Os caracteres morfométricos apresentados na tabela 4 foram utilizados para caracterização das espécies seguindo o trabalho de Roonwal (1970b) e Sands (1972). Como convenção sempre foi utilizada a lateral esquerda para as medidas. A fim de facilitar a comparação, foram elaboradas tabelas que incorporaram dados da literatura de outras espécies neotropicais não contempladas neste trabalho. Sempre que possível, as espécies próximas foram associadas numa mesma tabela, e quando isso não foi possível, foi seguida a ordem alfabética. As medidas do diâmetro máximo da fontanela são apresentadas junto às descrições por serem poucas as espécies que apresentam fontanela grande o suficiente para a medida.

0 índice da tíbia (largura da tíbia/comprimento da tíbia) foi calculado e correlacionado com a largura da cabeça. Foi calculado o $r$ de Pearson para as duas variáveis a partir dos dados das espécies encontradas no material estudado da Mata Atlântica, e plotado um gráfico com esses dados, usando o programa Excel. 


\subsection{Ilustração, mapa e material examinado}

Os operários e alados foram fotografados em um estereomicroscópio acoplado ao sistema de automontagem ou em um sistema de lentes acoplado a uma câmera fotográfica. As sequências obtidas foram tratadas no programa Helicon Focus. 0 tubo digestório foi ilustrado com auxílio de câmara clara acoplada ao estereomicroscópio, e suas microestruturas (moela, ornamentação do íleo e válvula entérica) foram fotografadas sob microscópio com a sequência de fotos feitas manualmente e posteriormente também tratadas no programa Helicon Focus. As ilustrações do tubo digestório e os esquemas de estrutura apresentados foram desenvolvidos usando o programa Inkscape.

Por convenção as ilustrações do tubo digestório serão apresentadas na sequência: vista dorsal, lateral direita, ventral e lateral esquerda. Na descrição do enrolamento do tubo digestório essas posições serão usadas como referência.

Foram incluídas ilustrações de Tetimatermes oliveirae e Rubeotermes jheringi, espécies que não ocorreram nas amostras da Mata Atlântica, e não foram redescritas neste trabalho, mas que são importantes para a chave de identificação.

Os mapas dos registros das espécies estudadas foram elaborados usando o referenciamento das localidades no Google Earth e posteriormente exportados para o Quantum Gis 2.18 (QGIS Development Team, 2018).

Na seção 4.3., no material examinado dos tipos, foram apresentadas a sigla da instituição de procedência, entre parênteses informações sobre os espécimes na amostra, e as informações exatamente como constavam na etiqueta.

0 restante do material examinado foi listado seguindo o modelo: PAÍS. Departamento/Estado/Província: cidade/lugarejo, data, coletor, (número da amostra). Em amostras com informações repetidas, foi conservado o primeiro registro completo e os demais apresentando apenas as informações que são diferentes. Foram usadas junto ao número da amostra as siglas entre parênteses: "a" para amostras contendo alados; "pq" para amostras contendo rainha primária e "n" para amostras que continham ninfas. $\mathrm{Na}$ ausência de qualquer sigla, a amostra contém apenas a casta do operário. 0 rei não foi identificado em nenhuma das amostras.

Foram incluídas excepcionalmente para a espécie Gên. 10 sp. FonA localidades que não correspondem à áreas de Mata Atlântica, pois essas informações estão no artigo que descreve o gênero, já submetido para publicação. 
As tabelas e imagens são apresentados no volume II dessa tese. As imagens estão organizadas em ordem alfabética do nome das espécies, por isso nem sempre a ordem de numeração das imagens seguirá a ordem em que aparecem no texto.

\subsection{Chave de Identificação}

Foram consideradas para a elaboração da chave de identificação dos operários dos gêneros neotropicais de Apicotermitinae, 62 espécies, somando as espécies publicadas de Apicotermitinae (possíveis de identificação hoje) e as espécies não descritas propostas neste trabalho. A chave foi contruída a partir de uma matriz de caracteres elaborada na plataforma online $X$ per $^{3}$ (Vignes-Lebbe et al. 2016) que compara os dados e gera a chave. 


\section{RESULTADOS}

Considerando as espécies não descritas identificadas neste trabalho, mais as espécies de Apicotermitinae neotropicais descritas até o presente momento e o status dos tipos de espécies cuja identificação não é possível ou não estão acessíveis, conclui-se que 62 espécies de Apicotermitinae neotropicais podem ser identificadas com segurança. Uma lista destas espécies é fornecida a seguir, onde o asterisco identifica aquelas espécies que são conhecidas apenas pela casta do operário: Amplucrutermes inflatus*, Anoplotermes bahamensis, Anoplotermes banksi, Anoplotermes inopinatus, Anoplotermes janus, Anoplotermes meridianus, Anoplotermes pacificus, Anoplotermes parvus, Anoplotermes punctatus, Anoplotermes sp. 1, Anoplotermes sp. 2*, Anoplotermes subterraneus, Aparatermes abbreviatus, Aparatermes cingulatus, Aparatermes silvestrii, Compositermes bani*, C. vindai, Disjunctitermes insularis*, Disjunctitermes sp. 1, Disjunctitermes sp. 2, Echinotermes biriba*, Gên. 1 sp. ES2*, Gên. 1 sp. S5*, Gên. 2 sp. MCH, Gên. 3 sp. ORQ*, Gên. 4 sp. V1, Gên. 5 sp. V4*, Gên. 6 sp. S8*, Gên. 7 sp. S7*, Gên. 8 sp. S3, Gên. 9 sp. V3, Gên. 10 sp. FonA, Gên. 10 sp. FonB*, Gên. 11 sp. ES3*, Gên. 11 sp. V2*, Gên. 12 sp. P1C, Gên. 13 sp. S6, Grigiotermes hageni, Grigiotermes sp. 1*, Humutermes krishnai, Humutermes noiroti, Hydrecotermes arienesho, Hydrecotermes kawaii, Hydrecotermes sp. 1, Longustitermes manni, Patawatermes nigripunctatus, P. turricola, Rubeotermes jheringi, Ruptitermes araujoi, Ruptitermes arboreus, Ruptitermes atyra, Ruptitermes bandeirai*, Ruptitermes cangua, Ruptitermes franciscoi, Ruptitermes kaapora, Ruptitermes krishnai, Ruptitermes maraca, Ruptitermes piliceps, Ruptitermes pitan, Ruptitermes reconditus, Ruptitermes xanthochiton, Tetimatermes oliveirae*.

Uma descrição geral para a subfamília Apicotermitinae, "Grupo Anoplotermes" neotropical, é apresentada na seção 4.1, seguida por uma chave de identificação (seção 4.2) ainda preliminar e não testada para as 62 espécies (listadas acima), na qual é possível identificar espécies ou grupos de espécies.

Com a seção 4.3 "Redescrições e considerações sobre o status de parte dos tipos de Apicotermitinae", pretende-se fornecer um panorama do que é ou não possível saber a partir dos tipos das espécies com descrições antigas, acessíveis, e as decisões taxonômicas que devem ser tomadas numa futura publicação. Aqui o esforço foi concentrado nos tipos das espécies descritas entre 1858 e 1955 não tratadas nos 
trabalhos de Bourguignon et al. (2010; 2016a). Para informação sobre os outros tipos estudados, não tratados na seção 4.3. consulte a tabela 1.

Não foi estudado nenhum tipo das seguintes espécies: Anoplotermes ater (Hagen 1858), Anoplotermes grandifons Snyder 1926, Anoplotermes howardi Snyder 1926, Anoplotermes schwarzi Banks 1919. Os tipos das espécies Anoplotermes bolivianus, Anoplotermes brucei, Anoplotermes gracilis, Anoplotermes hondurensis, Anoplotermes punctatus, Anoplotermes rotundus e Anoplotermes tenebrosus, foram estudados, mas não ofereceram condições suficientes para identificação.

A seção 4.4 apresenta as redescrições das espécies conhecidas e descrições das espécies encontradas na Mata Altântica bem como comparações e lista de material examinado. As informações de algumas das estruturas omitidas nas descrições e redescrições são iguais àquelas descritas para a subfamília.

Foram identificadas nas amostras estudadas das áreas de Mata Atlântica 35 espécies, das quais 15 correspondem a espécies conhecidas para a ciência enquanto, 20 são consideradas espécies não descritas (Tab. 5)

O agrupamento das espécies em gêneros foi certamente o maior desafio deste trabalho, pois as características aparecem nas espécies em diferentes combinações. É difícil discernir características que seriam sinais filogenéticos, de convergências ecológicas. Considerando isso, foram propostos 13 gêneros não descritos, dos quais 10 são monotípicos (Tab. 5). Um deles, Gênero 10, foi submetido para publicação e conta com duas espécies Gên. 10 sp. FonA e Gên. 10 sp. FonB, sendo que somente a primeira delas ocorre na Mata Atlântica.

\subsection{Apicotermitinae da Região Neotropical ("Grupo Anoplotermes”)}

Alado: cápsula cefálica trapezoidal em vista dorsal, dorsoventralmente achatada a convexa em perfil; duas manchas frontais oblongas localizadas, em vista dorsal, entre o pós-clípeo e os ocelos; fontanela arredondada, elipsoide ou em forma de gota, inconspícua a grande e destacada, ocupando uma região deprimida a ressaltada, pode apresentar dimorfismo sexual; mancha mediana arredondada a elipsoide, inconspícua a proeminente; sutura em "Y" geralmente não visível; antena com 15 artículos, terceiro a quinto artículos de comprimento variável, demais artículos aumentam em comprimento progressivamente; olhos arredondados de tamanho variável, nunca muito pequenos; 
ocelos pequenos, reniformes, geralmente separados da margem do olho pelo seu diâmetro; pós-clípeo moderadamente inflado, com a linha mediana geralmente conspícua e incompleta; margem entre o pós-clípeo e cápsula cefálica de reta a côncava; labro linguiforme com a porção central esbranquiçada e as margens hialinas. Mandíbula esquerda com dente apical de muito curto a longo; M1+2 formando uma margem cortante de comprimento variável; incisão conspícua entre M1+2 e M3; M3 triangular a arredondado; processo pré-molar inconspícuo a conspícuo, com posição variável; processo molar oculto ou não pela proeminência molar, proeminência molar pouco desenvolvida; sem estrias; mandíbula direita com o dente apical muito curto a longo; M1 triangular; M2 triangular com as margens geralmente formando um ângulo obtuso; placa molar pouco desenvolvida, sem estrias; pronoto variável, com a largura máxima igual ou menor a largura da cabeça com os olhos; margem anterior com ou sem uma incisão central discreta, com ou sem uma ligeira elevação na área central, como uma pequena sela, vista de perfil. Tíbia anterior geralmente não inflada. Fêmeas geralmente maiores que os machos. Cápsula cefálica com densa cobertura de pelos, e número e comprimento de cerdas variável. Asas com cerdas concentradas na região das nervuras e escamas alares, cerdas esparsas nas áreas membranosas; asas ricamente ornamentadas com micrásters asteroides; pro-, meso- e metanotos, tergitos e esternitos, coxas, fêmures e tíbias com pilosidade variável, na maior parte das espécies sendo composta por cerdas de diferentes tamanhos. Esporões da tíbia 2:2:2. Coloração da cápsula cefálica de alaranjada a castanho escura; manchas frontais geralmente pouco mais claras que o restante da cápsula cefálica com margens pouco definidas; fontanela de cor variável; mancha mediana geralmente da cor do restante da cápsula cefálica; asas iridescentes a cinza-azuladas in vivo, alaranjadas a castanhas após fixação em álcool; pronoto e pós-clípeo pouco mais claros que a cápsula cefálica.

Soldados: ausentes.

Operário: mono- ou dimórficos; cápsula cefálica arredondada ou mais larga que comprida em vista dorsal, dorsoventralmente achatada (na maioria das espécies) a convexa em perfil; fontanela arredonda a elipsoide, inconspícua a ocupando $3 / 4$ da cápsula cefálica em vista dorsal; antena com 14 artículos, terceiro a sexto de comprimento variável; pós-clípeo não inflado a fortemente inflado; margem entre o pós- 
clípeo e cápsula cefálica reta a côncava; labro linguiforme com a porção central esbranquiçada e as margens hialinas. Mandíbula esquerda com dente apical de muito curto a longo, M1+2 formando uma margem cortante de comprimento variável; incisão conspícua entre M1+2 e M3; M3 triangular a arredondado; processo pré-molar nunca conspícuo; processo molar oculto ou não pela proeminência molar; proeminência molar desenvolvida, sem estrias; mandíbula direita com o dente apical muito curto a longo; M1 triangular; M2 triangular com as margens geralmente formando um ângulo reto; placa molar desenvolvida, sem estrias. Pronoto com lobo anterior geralmente mais longo que o lobo posterior (bem curto); mesonoto e metanoto subretangulares com margens laterais arredondadas; glândulas salivares visíveis em alguns espécimes (variável intrae interespecificamente) por transparência, órgãos deiscentes presentes em algumas espécies; tíbia não inflada a fortemente inflada, em forma de colher em Tetimatermes. Tubo digestório visível por transparência; papo de volume variável, assimétrico; moela caliciforme, em algumas espécies visualmente separada do papo, com armadura fortemente reduzida, com pregas fracamente distinguíveis na estrutura in situ, indistinguíveis na estrutura montada em lâmina, com 4 a 6 pulvilli, ornamentados com escamas; segmento misto ausente, vestigial ou presente; lingueta mesentérica, quando presente, longa partindo do lado esquerdo ao direito em vista ventral; porção final da lingueta fortemente inflada ou não; íleo com calibre uniforme em toda extensão, formando um 'C' invertido em vista ventral, em todas as espécies, terminando dorsalmente abaixo do colo, na lateral direita ou ventralmente; válvula entérica armada ou inerme, seis pregas simétricas ou não, com disposição variável de escamas; assentamento da válvula entérica tubular, curto ou longo, ou trilobado; primeira porção da pança em forma de cabaça e segunda porção da pança em forma de 'S'; ístmo conspícuo; colo de comprimento uniforme, partindo da direita para a esquerda, contornando o mesêntero em vista dorsal; reto de calibre e forma variável. Cápsula cefálica sem pelos curtos, com cobertura de cerdas variável; pro-, meso- e metanoto, coxas, fêmures e tíbias, tergitos e esternitos com cobertura de cerdas variável; esporões da tíbia 2:2:2. Coloração da cápsula cefálica esbranquiçada a castanho-escura; fontanela esbranquiçada a hialina; pro-, meso-, metanotos e tergitos alaranjados a castanhos em algumas espécies de Ruptitermes, nas demais espécies, hialinos.

Comparações: ver tabelas 6 e 7. 
Comentários: nas descrições a seguir as características que não apresentam grande variação do padrão descrito para a subfamília foram ocultas para que as descrições ficassem mais curtas e ressaltassem as características que variam na espécie ou gênero descritos. No da descrição das mandíbulas, optou-se por ocultar a descrição da mandíbula direita já que ela é mais homogênea entre as espécies estudadas. 0 dente apical da mandíbula direita segue o descrito para a o dente apical da mandíbula esquerda.

\subsection{Chave para os operários das espécies e grupos de espécies de Apicotermitinae neotropicais}

É apresentada aqui uma primeira abordagem para o desenvolvimento de uma chave de identificação. A chave a seguir é uma versão ligeiramente modificada da chave gerada pelo $\mathrm{Xper}^{3}$. 0 objetivo inicial era gerar uma chave que usasse minimamente o recurso da dissecção e montagem de lâminas. 0 passo 11a, por exemplo, agrupa uma série de espécies que são separadas entre si por detalhes da válvula entérica (vide imagens referenciadas). Para os passos que diferenciam válvulas entéricas armadas de inermes, a dissecção grosseira e observação sob lupa é, na maioria dos casos, suficiente para determinar essas características.

1a. Fontanela tomando $3 / 4$ da cabeça em vista dorsal (Figs. 215-216) ... operário 1 de Gên. 10 sp. FonA (Figs. 215-218, 222-226)

1b. Fontanela de forma diversa ... 2

2a. Tíbia anterior em forma de colher (Fig. 313)... Tetimatermes oliveirae (Figs. 313, 314)

2b. Tíbia anterior de forma diversa ... 3

3a. Órgãos deiscentes presentes (animal fixado) (Figs. 175, 207, 299)...4

3b. Órgãos deiscentes ausentes (animal fixado) ...5

4a. Tíbia anterior com duas fileiras de cerdas grossas (Fig. 234)...6 
4b. Tíbia anterior com cerdas grossas desorganizadas ... Ruptitermes araujoi, Ruptitermes atyra, Ruptitermes fransciscoi, Ruptitermes kaapora, Ruptitermes krishnai, Ruptitermes xanthochiton

4c. Tíbia anterior sem cerdas grossas ...7

5a. Lingueta mesentérica inflada (Fig. 16, 24, 44, 184, 294)...11

5b. Lingueta mesentérica ausente ou não inflada ...9

6a. Coxa anterior com cerdas grossas ... Ruptitermes cangua

6b. Coxa anterior sem cerdas grossas ... Gên. 11 sp. V2 (Fig. 232-236)

7a. Lingueta mesentérica inflada ... Patawatermes turricola (Figs. 288, 290-294)

7b. Lingueta mesentérica ausente/vestigial ou se presente não inflada ...10

9a. Tíbia anterior com duas fileiras de cerdas grossas (Fig. 234), fontanela mediana com margens inconspícuas ...13

9b. Tíbia anterior com duas fileiras cerdas espiniformes (Fig. 223); fontanela grande com margens bem marcadas ... operário 2 de Gên. 10 sp. FonA (Figs. 215-218, 222-226), Gên. 10 sp. FonB.

9c. Tíbia anterior sem cerdas grossas ...14

10a. Lingueta mesentérica presente ... Gên. 9 sp. V3 (Figs. 205-207, 210-214)

10b. Lingueta mesentérica ausente ou vestigial ...15

11a. Ìleo terminando dorsalmente ... Anoplotermes janus (Fig. 34), Anoplotermes parvus, Anoplotermes sp. 2 (Figs. 73-74), Humutermes krishnai (Figs. 264-265), Humutermes noiroti, Anoplotermes bahamensis, Anoplotermes banksi (Figs. 22-23), Anoplotermes inopinatus, Anoplotermes pacificus (Figs. 53-55), Anoplotermes sp. 1(Figs. 69-70) 11b. Ìleo terminando na lateral direita, operários com largura da cabeça maior que 0,80 mm ... Gên. 6 sp. S8 (Figs. 180-185)

12a. Assentamento da válvula entérica tubular ...16

12b. Assentamento da válvula entérica trilobado ... Longustitermes manni (Figs. 275- 
280), Anoplotermes meridianus (Figs. 37-39, 41-44)

13a. Assentamento da válvula entérica tubular ... Gên. 8 sp. S3 (Figs. 194-196, 198-200)

13b. Assentamento da válvula entérica trilobado ... Aparatermes silvestrii (Figs. 102-107)

14a. Lingueta mesentérica presente ... Disjunctitermes insularis, Disjunctitermes sp. 1

(Figs. 119-120,122-124), Disjunctitermes sp. 2 (Figs. 127-128, 130-131)

14b. Lingueta mesentérica ausente ou vestigial ...17

15a. Coxa anterior com cerdas grossas ... Ruptitermes maraca, Ruptitermes piliceps, Ruptitermes pitan, Ruptitermes reconditus

15b. Coxa anterior sem cerdas grossas ... 18

16a. Válvula entérica armada ... Grigiotermes hageni (Figs. 250-251, 254-255),

Grigiotermes sp. 1 (Figs. 252-253, 256-258), Patawatermes nigripunctatus (Figs. 281284), Amplucrutermes inflatus

16b. Válvula entérica inerme ... Anoplotermes subterraneus (Figs. 77-80)

17a. Coxa anterior com cerdas grossas ...19

17b. Coxa anterior sem cerdas grossas ...20

18a. Válvula entérica armada ... Ruptitermes bandeirai (Figs. 294-296), Gên. 5sp. V4(Figs. 173-179)

18b. Válvula entérica inerme ... 21

19a. Assentamento da válvula entérica tubular ... Gên. 4 sp. V1

19b. Assentamento da válvula entérica trilobado ... Rubeotermes jheringi (Figs. 295-296)

20a. Assentamento da válvula entérica tubular ... 22

20b. Assentamento da válvula entérica trilobado ... 23

21a. Íleo terminando dorsalmente ... Gên. 1 sp. ES2 (Figs. 133-137), Gên. 1 sp. S5 (Figs. 
138-142), Ruptitermes arboreus

21b. Íleo terminando na lateral direita ... Gên. 7 sp. S7 (Figs. 186-191)

22a. Válvula entérica modificada com armadura localizada no final do assentamento da válvula entérica ... Compositermes bani, Compositermes vindai (Figs. 110-116)

22b. Válvula entérica não modificada ...24

23a. Válvula entérica armada ... 25

23b. Válvula entérica inerme ... Aparatermes abbreviatus (Figs. 82-87), Aparatermes cingulatus (Figs. 90-99)

24a. Válvula entérica armada ... Gên. 2 sp. MCH (Figs. 146-147, 149-155),

Amplucrutermes inflatus

24b. Válvula entérica inerme ... Gên. 11 sp. ES3 (Figs. 232-236), Gên. 13 sp. S6 (Figs. 243247), Hydrecotermes arienesho, Hydrecotermes kawaii, Hydrecotermes sp. 1 (Figs. 268$269,271-274)$

25a. Íleo terminando lateral direita ... Gên. 3 sp. ORQ (Figs. 156-163)

25b. Íleo terminando ventralmente ... 26

26a. Processo molar oculto ... Echinotermes biriba

26b. Processo molar não oculto ... Gên. 12. sp. P1C (Figs. 237-242)

\subsection{Redescrições e considerações sobre o status de parte dos tipos de Apicotermitinae}

Para as espécies com tipos estudados e identificadas entre as amostras da Mata Atlântica, foi incluído um comentário e material tipo examinado nesta seção, porém a redescrição foi feita na seção 4.4 . 
4.3.1. Anoplotermes ater (Hagen 1858): 195-196, 243

(Fig. 9)

Termes (Eutermes) ater Hagen 1858

Tipos: alado (BMNH), não examinado; alado (MCZ), não examinado (Fig. 9); alado (MLU), não examinado.

Localidade tipo: BRASIL. Rio de Janeiro: Nova Friburgo.

Comentários: Nenhum material dessa espécie foi estudado pessoalmente, no entanto foi analisado o material fotográfico do síntipo depositado no MCZ. 0 espécime é um alado em montagem seca, fungado (Fig. 9). Os outros dois síntipos (BMNH e MLU) também são alados e muito possivelmente nas mesmas condições. Além de ser muito difícil definir uma espécie unicamente por características do alado, o espécime em questão não oferece condições para estudo das mandíbulas (sem destruir o material), da coloração geral e pilosidade das tíbias. Dessa forma, é impossível determinar a identidade dessa espécie a partir do tipo disponível.

4.3.2. Anoplotermes bolivianus Snyder 1926: 46-47

Anoplotermes (Anoplotermes) bolivianus Snyder 1926

Tipos: alado (USNM), examinado.

Localidade tipo: BOLÍVIA. La Paz: Tumupasa.

Alado: fontanela elipsoide. Demais características como descrito para o alado de Anoplotermes (ver seção 4.4 para a descrição de Anoplotermes, e comentários a seguir).

Operário: Não foi possível estudar o enrolamento do tubo digestório. Demais características como descrito para Anoplotermes (ver seção 4.4 para a descrição de Anoplotermes, e comentários a seguir). 
Material examinado:

-AMNH- Topotype. Metatype. Tumupasa. Bolivia. Det. TE Snyder. Coll. W M Mann. Dec. 2 winged Im. (dois alados, um inteiro e outro sem cabeça e com o abdômen danificado, em ácool, não é tipo)

-USNM-Paratype. USNM 001697. Tumupasa. WM Mann, Dec, Bolívia, The Mulford Exploration. (duas cabeças de alados e partes de corpos de alados; três operários muito ressecados, duas cabeças e um abdômen completo)

Comentários: 0 material com operários do USNM estava em condições muito ruins de conservação. Foram realizadas tentativas de reidratar um espécime a fim de realizar dissecção, porém sem sucesso. Dessa forma, a espécie fica impossível de se identificar a partir do tipo disponível, sendo possível apenas a indicação de sua semelhança com os alados das espécies de Anoplotermes.

\subsubsection{Anoplotermes brucei Snyder 1955: 300}

(Tabs. 8, 9; Figs. 25-28)

Tipos: alado, operário (AMNH), examinado; alado, operário (USNM), não examinado. Localidade tipo: BOLÍVIA. Beni: José Ballivián, Lago Rogagua.

Alado (Fig. 27): fontanela circular, bem marcada, região do vértice deprimida; mancha mediana arredondada; antenas ausentes no espécime. Mandíbula esquerda com dente apical maior que M1+2; margem proximal do M1+2 alongada, cortante; M3 pequeno triangular; processo pré-molar conspícuo afastado da margem do M3; processo molar não oculto pela proeminência molar. Pronoto subhexagonal, com a largura máxima menor que a largura da cabeça, margem anterior reta com uma incisão central discreta, margem anterior ligeiramente levantada. Cápsula cefálica com cobertura densa de cerdas de mesmo comprimento e pelos curtos; pronoto com cerdas nas margens e pelos curtos; tergitos e esternitos com cerdas curtas e pelos curtos cobrindo o centro das placas. Coloração da cápsula cefálica alaranjada; manchas frontais pouco mais claras que o restante da cápsula cefálica com margens bem definidas; fontanela pouco mais clara que o restante da cápsula cefálica; pronoto de mesma cor que a cápsula cefálica. 
Operário (Fig. 25-26, 28): fontanela pequena, arredondada e bem marcada, localizada numa região deprimida (Fig. 26); antena incompleta no espécime; pós-clípeo moderadamente inflado (Fig. 25). Espécime sem mandíbulas para analisar. Fêmur com a face interna plana; tíbia inflada. Tubo digestório com segmento misto danificado; íleo terminando dorsalmente abaixo do colo; válvula entérica inerme (Fig. 28), com seis pregas simétricas subovaladas, porção central das pregas (Fig. 28) com escamas pequenas com ápices pontiagudos voltados para a pança, margens lisas, e escamas maiores ao redor, de mesmo formato; assentamento da válvula entérica tubular, curto. Cápsula cefálica coberta por cerdas longas, medianas e curtas (Fig. 25). Pronoto com cerdas longas concentradas na margem do lobo anterior (Fig. 25). Tergitos e esternitos com cerdas medianas no centro das placas. Coxas com 3-5 cerdas grossas. Fêmures com duas fileiras de cerdas de diferentes comprimentos. Tíbias com duas fileiras de cerdas, com 7-8 cerdas longas. Coloração da cápsula cefálica amarela alaranjada (Figs. 25-26). Fontanela esbranquiçada (Fig. 26).

Material examinado:

-AMNH (um alado fêmea) - Paratype, type vial, det. TE Snyder "A. pacificus F Muller det TE Snyder 1926g: 58” Rosario (Lake Rogagoa) Bolivia. Inhills. Coll. WM Mann, xi.1921. 1 Im. $q$ from Snyder '62.

-AMNH (um alado partido em três pedaços, uma asa solta e um operário grande sem mandíbulas, sem mesentêro e íleo)- Paratype colony. Det. A. Emerson 1962. “A. pacificus F. Muller det. TE Snyder 1926g: 48. Rosario. Bolivia. Xi.1921. coll. WM Mann. 1 Im. 1? .

Comentários: As informações resgatadas indicam que o operário de Anoplotermes brucei é semelhante aos operários de Aparatermes silvestrii e de Gênero 11, mas a espécie seria mais bem alocada em um novo gênero pelas características da pilosidade da cabeça, fêmur e tíbia, ausência de lobos no assentamento da válvula entérica e pelo padrão de escamas da válvula entérica no operário. 0 alado de Anoplotermes brucei (Fig. 27) e Aparatermes (Figs. 81, 89) (exceto Aparatermes silvestrii) são muito parecidos pela forma da fontanela e tamanho dos olhos (pequenos em ambos). É possível afirmar que esta espécie deve ser transferida de Anoplotermes, pois no alado a mandíbula esquerda apresenta o processo pré-molar afastado do M3 e o processo molar não oculto pela proeminência molar e no operário as diferenças mais marcantes são pilosidade da 
cabeça, fêmur e tíbias. Talvez com o tipo do USNM seja possível definir o melhor agrupamento.

\subsubsection{Anoplotermes distans Snyder 1926: 48-49}

(Tab. 20; Fig. 29-33)

Anoplotermes (Anoplotermes) distans Snyder 1926

Tipos: operários (AMNH), examinados; alado (USNM) não examinado.

Localidade tipo: BOLÍVIA. Beni: José Ballivián, Rosário.

Comentários: Ver comentários sob Anoplotermes meridianus a seguir.

Material examinado:

-AMNH (três operários inteiros em bom estado)- Cotype from type colony det. TE Snyder. Rosario, Bolivia. Coll. WM Mann. xi.1921. ఫ (3 operários inteiros em bom estado).

\subsubsection{Anoplotermes gracilis Snyder 1922: 28-29}

Tipos: alados (AMNH) examinados; alado (USNM) não examinado.

Localidade tipo: PANAMÁ. Panamá: Ancon.

Comentários: 0 exame do síntipo, que possui exclusivamente alados, não foi conclusivo. Não foi possível determinar sequer se a espécie permaneceria no gênero Anoplotermes, pois o material estava em mau estado.

Material examinado:

-AMNH (dois machos alados e duas fêmeas aladas)- Cotype from type vial det TE Snyder, Ancon, CZ, Panamá, 19.iv.1919. Wasp's nest. Coll. HF Dietz G475a. Hopk. US. 14124h. Im. -USNM (não é tipo; duas cabeças de alados e dois abdomens e parte de um abdômen)USNM001728 (141249 Hopk. U. S.) CT474b, Ancon, CZ, 4.19.19 HTD. 


\subsubsection{Anoplotermes grandifons Snyder 1926: 50-51}

Anoplotermes (Anoplotermes) grandifons Snyder 1926

Tipos: alado (USNM), não examinado.

Localidade tipo: BOLÍVIA. Beni: José Ballivián, Rosário.

\subsubsection{Anoplotermes hondurensis Snyder 1924: 37-38}

Tipos: alados (AMNH), examinados; alado (USNM), não examinado. Localidade tipo: HONDURAS. Atlántida: La Ceiba.

Alado: fontanela elipsoide. Demais características como descrito para o alado de Anoplotermes (ver seção 4.4.1. para a descrição, e comentários a seguir).

Comentários: Amostra ressecada. A informação sobre pilosidade das pernas foi perdida e as tíbias estão quebradas ou amassadas, ficando apenas a indicação de sua semelhança com os alados das espécies de Anoplotermes.

Material examinado:

- AMNH (dois alados em mal estado)- Cotype, det. TE Snyder, La Ceiba, Honduras, Coll. FJ Dyer, 19.v.1916, Im.

-USNM (não é tipo, vários alados em bom estado)- USNM 001739, UFC No 168-1, La Lima, Honduras, May, 17, '65, flying after heavy rain, HE.

4.3.8. Anoplotermes howardi Snyder 1926: $51-52$

Anoplotermes (Anoplotermes) howardi Snyder 1926

Tipos: alado (USNM), não examinado.

Localidade tipo: BOLÍVIA. Beni: José Ballivián, Rosário.

4.3.9. Anoplotermes meridianus Emerson 1925: 421

(Tabs. 19, 20; Figs. 35-45)

Anoplotermes (Anoplotermes) meridianus Emerson 1925 
Tipos: alado, operário (AMNH), examinados; alado, operário (IEA), não examinados; alado, operário (USNM), não examinados.

Localidade tipo: ARGEnTINA. Buenos Aires: Nunez; Córdoba: Cernadas; Entre Ríos: Chajari; Santa Fe: Sunchales; Temperley; Villa Catalinas. PARAGUAY. Paraguari. URUGUAY: La Sierra.

Descrição: ver Anoplotermes meridianus na seção 4.4 .

Material Examinado:

-USNM (não é tipo, quatro alados inteiros de espécies diferentes e partes de outro alado)- USNM 003728, det. Snyder + 2 other A. spp.; C. rutitus partial. 18 July '64, E Green. Md.

-AMNH (seis alados, machos e fêmeas, dois operários inteiros, duas cabeças, um operário danificado e um abdômen de operário)- Paratype. Type colony det. A Emerson 1957. “A. morio Latr.” det. coll. F. Silvestri, Sunchales (Prov. S. Fé) Argentina, 11.xii.1898. Im. ఫ . Fr. Silvestri coll. '57.

Comentários: Baseado no exame do tipo de Anoplotermes distans e Anoplotermes meridianus pode-se concluir que as duas espécies devem ser sinonimizadas no futuro, sendo Anoplotermes meridianus sinônimo sênior. As características determinantes para esta conclusão são: lingueta mesentérica curta inflada, o assentamento da válvula entérica trilobado, o padrão de escamas da válvula entérica e o padrão da pilosidade da cápsula cefálica, que são iguais nas duas espécies.

\subsubsection{Anoplotermes punctatus Snyder 1926: 56}

(Figs. 57-60)

Anoplotermes (Anoplotermes) punctatus Snyder 1926

Tipos: operário (AMNH) examinado; alado (USNM), não examinado.

Localidade tipo: BOLÍVIA. Beni: José Ballivián, Rosário. 
Operário: margem dorsal da cápsula cefálica convexa em perfil (Fig. 57) fontanela pequena, arredondada, com margens pouco definidas (Fig. 58); pós-clípeo não inflado (Fig. 57). Mandíbula não examinada. Tíbia moderadamente inflada. Tubo digestório danificado; válvula entérica inerme (Figs. 59-60), com seis pregas simétricas, subretangulares, porção central das pregas com 3-4 escamas pequenas com um espinho voltado para a pança, demais escamas maiores, subhexagonais, com margens lisas. Cápsula cefálica densamente coberta por cerdas medianas e curtas. Pronoto (Fig. 57) com cerdas longas concentradas nas margens do lobo anterior e posterior. Meso- e metanoto com cerdas longas e curtas no centro da placa. Tergitos e esternitos com cerdas curtas no centro das placas. Coloração da cápsula cefálica amarelada. Fontanela esbranquiçada/hialina.

Material Examinado:

-AMNH (um operário previamente dissecado, sem mesêntero e segmento misto)- Cotype from type colony. Det. TE Snyder. Rosario, Bolivia, x.1921. Coll. WM Mann, 1 ఛ.

Comentários: a partir do material examinado é muito difícil classificar esta espécie, pois não há informação sobre o enrolamento do tubo digestório. As características externas são semelhantes as dos operários de Anoplotermes e a válvula entérica (Fig. 59-60) é parecida com a das espécies de Gênero 1 (Figs. 136-137, 142).

\subsubsection{Anoplotermes pyriformis Snyder 1934: 96}

(Figs. 61-62)

Anoplotermes (Anoplotermes) pyriformis Snyder 1934

Tipos: alado (AMNH) examinado; alado (USNM), não examinado.

Localidade tipo: COSTA RICA. Santa Clara, Hamburg Farm.

Alado: Como o descrito para Anoplotermes subterraneus (ver comentários em Anoplotermes subterraneus a seguir). 
Material examinado:

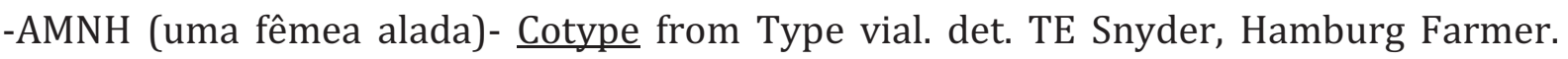
Santa Clara Prov. Costa Rica, 25.ix.1930, coll. F Neverman, 1 Im.

\subsubsection{Anoplotermes rotundus Snyder 1926: 56-57}

Anoplotermes (Anoplotermes) rotundus Snyder 1926

Tipos: alado (AMNH), examinado; alado (USNM), examinado.

Localidade tipo: BOLÍVIA. Beni: José Ballivián, Rosario.

Alado: margem dorsal da cápsula cefálica convexa em perfil; fontanela grande, arredondada, bastante característica; pós-clípeo moderadamente inflado. Mandíbulas não examinadas. Pronoto subhexagonal, com a largura máxima menor que a largura da cabeça, margem anterior sem uma incisão central, sem emarginados marcantes, margem posterior sem incisão. Cápsula cefálica com cerdas mais esparsas e pelos curtos. Pronoto com cerdas e pelos curtos. Tergitos e esternitos com cerdas curtas e pelos curtos cobrindo o centro das placas. Coloração da cápsula cefálica castanho-alaranjada, manchas frontais pouco mais claras que o restante da cápsula cefálica com margens bem definidas. Região da fontanela pouco mais clara que o restante da cápsula cefálica. Pronoto mais claro que a cápsula cefálica.

Comentários: Com base nas características da fontanela e da pilosidade do alado, a espécie parece não estar bem alocada em Anoplotermes, mas, pelo o mau estado dos espécimes, e a ausência de operários para estudo, não é possível um parecer mais conclusivo.

Material examinado:

-USNM (um alado danificado)- USNM001575, Paratype, Rosario, Bolívia, Nov. The Mulford Exploration.

-AMNH (uma fêmea alada)- Cotype from type colony, det. TE Snyder, Rosario, Bolivia, Coll. WM Mann xi.1921, 1 Im. 


\subsubsection{Anoplotermes schwarzi Banks 1919: 481}

Tipo: alado (USNM), não examinado.

Localidade tipo: CUBA. Cayamas.

\subsubsection{Anoplotermes subterraneus Emerson 1925: 425-426}

(Tabs. 12, 13; 75-80)

Anoplotermes (Anoplotermes) subterraneus Emerson, 1925

Tipos: alados, operários (AMNH), examinados; alados, operário (USNM), examinados. Localidade tipo: GUIANA. Cuyuni-Mazaruni: Bartica, Kartabo.

Alado: margem dorsal da cápsula cefálica convexa em perfil (Fig. 75); fontanela grande, em forma de gota (Fig. 76), bem definida nas fêmeas, pouco conspícua no macho. Pronoto subhexagonal, com a largura máxima igual ou menor que a largura da cabeça, margem anterior sem uma incisão central, sem emarginados marcantes, margem posterior com uma incisão discreta (Fig. 76). Mandíbula não examinada. Cápsula cefálica com cobertura de cerdas medianas e pelos curtos (Fig. 75). Pronoto com poucas cerdas medianas nas margens e pelos curtos (Fig. 75); tergitos e esternitos com cerdas curtas e pelos curtos cobrindo o centro das placas. Coloração da cápsula cefálica alaranjada, manchas frontais pouco mais claras que o restante da cápsula cefálica com margens bem definidas (Fig. 75); fontanela pouco mais clara que o restante da cápsula cefálica; pronoto mais claro que a cápsula cefálica.

Operário: fontanela em forma de gota (Fig. 78), com margens pouco definidas; pósclípeo moderadamente inflado (Fig. 77). Mandíbula esquerda com ponta de A na mesma altura que a de M1+2; M3 triangular com as margens formando um ângulo reto/agudo; processo molar semioculto pela proeminência molar; proeminência molar desenvolvida; sem estrias. Sem órgãos deiscentes visíveis. Tíbia fortemente inflada (Fig. 77, 79). Tubo digestório sem segmento misto; porção final do mesêntero levemente dilatada; íleo com calibre uniforme em toda extensão, formando um ' $C$ ' invertido em vista ventral, terminando na lateral direita; válvula entérica inerme, com seis pregas subovaladas, simétricas, com escamas de tamanho e disposição uniforme, com margens lisas; na 
porção distal da prega o arranjo de escamas lembra o de uma pinha (Fig. 80); assentamento da válvula entérica tubular. Cápsula cefálica com cerdas de dois comprimentos, poucas medianas, e cerdas curtas densamente distribuídas (Fig. 77). Pronoto com cerdas longas concentradas na margem do lobo anterior. Meso- e metanotos com cerdas longas nas margens. Tergitos e esternitos com cerdas curtas no centro das placas. Coloração da cápsula cefálica amarelada (Figs. 77-79). Fontanela esbranquiçada/hialina (Fig. 78).

Material examinado:

-AMNH (uma fêmea alada, e um operário ressecado)- Holotype, Imago; Morphotype, $\Varangle$ det. coll. AE Emerson Kartabo, Bartica, District, Br. Guiana, 18.vi.1920. \#49 \#1086 AS (Light's Notebook).

-AMNH Paratype from holotype colony, det. coll. AE Emerson Kartabo, Bartica, District, Br. Guiana, 18.vi.1920. \#49 \#1086 AS (Light's Notebook) Im. ఫ , Light Coll.

-AMNH (19 operários inteiros, duas cabeças de operário, um macho alado e cinco fêmeas aladas em mau estado, um abdômen de alado)- Paratype from holotype colony, det. coll. AE Emerson Kartabo, Bartica, District, Br. Guiana, 18.vi.1920. \#49 \#1086 AS (Light's Notebook) Im. ఢ , Light Coll.

-AMNH (dois alados inteiros, macho e fêmea, e um alado danificado com a mandíbula aberta) Metatype, Topotype, Autotype, det. comp. A Emerson, Kartabo, Br. Guiana, 16.vii.1920. \#110A. Coll. WM Wheeler in WAP nest.

-USNM (1 operário e 2 alados (macho e fêmea) em boas condições)- USNM 001732, Paratype from Holotype colony, 18.vi.1920, det. coll. AE Emerson, \# 49, Br. Guiana.

Comentários: Os alados de Anoplotermes pyriformis e Anoplotermes subterraneus analisados são muito similares, e apesar de não ter sido feito o exame das mandíbulas, com base no padrão de pilosidade da cápsula cefálica e na forma singular da fontanela, em forma de gota, as duas espécies devem ser sinonimizadas no futuro, com Anoplotermes subterraneus sendo sinônimo sênior. 0 operário de Anoplotermes subterraneus é semelhante à Amplucrutermes inflatus Bourguignon e Roisin 2016, em Bourguignon et al. 2016a, devendo ocorrer uma futura transferência da espécie para Amplucrutermes. 
4.3.15. Anoplotermes tenebrosus (Hagen 1858): 193-195, 243, 284

Termes (Eutermes) tenebrosus Hagen 1858

Tipos: alado (AMNH) examinado, alado (MCZ) não examinado (Fig. 10), alado (NHMW) não examinado, alado (RIB) não examinado, alado (ZMB) não examinado.

Localidade tipo: BRASIL. São Paulo: Iperó, Floresta Nacional de Ipanema (ver comentários).

Comentários: 0 síntipo analisado é uma fêmea em mau estado de conservação. Não é possível fazer inferência segura a partir dela, pois não é possível avaliar a fontanela, pilosidade da cápsula cefálica, e estado do pós-clípeo. 0 síntipo do MCZ (Fig. 10) parece estar também em mau estado e o mesmo é esperado para os demais síntipos. No trabalho de Hagen (1858), consta como localidade tipo da espécie "Ypanema, St. Paulo". Papavero (1971, pg. 81) indica que Ypanema seria sinônimo de "Varnhagen". Por sua vez, Giesbrecht (2018) descreve que tanto "Ypanema" quanto "Varnhagen" denominam a mesma antiga estação ferroviária no estado de São Paulo, localizada dentro da Floresta Nacional de Ipanema, no município de Iperó.

Material Examinado:

-AMNH (uma fêmea alada seca e fungada)- Anoplotermes (A.) tenebrosus (Kollar), Cotype, "Termes tenebrosus" det. Kollar and H. Hagen, Ypanema, St. Paulo, Brazil. Coll. Natterer, $1 \mathrm{Im}$.

\subsubsection{Aparatermes abbreviatus (Silvestri 1901): 8}

(Tabs. 10, 11; Figs. 81-87)

Anoplotermes cingulatus abbreviatus Silvestri, 1901

Tipos: alado, operário (AMNH) examinados; alado, operário (IEA) não examinados; alado, operário (USNM) não examinados.

Localidade tipo: ARGENTINA. Santa Fé: Sunchales.

Descrição: ver Aparatermes abbreviatus na seção 4.4 . 
Material examinado:

-AMNH (um macho, uma fêmea alada e dois operários)- Cotype det. + coll. F Silvestri, Sunchales, Argentina, xii.1898, Im. .

-USNM (não é tipo, um alado, dois operários)- USNM 000067 Sunchales, Santa Fé, Argentina.

4.3.17. Aparatermes cingulatus (Burmeister 1839): 767-768

(Tabs. 10, 11; Figs. 88-99)

Termes cingulatus Burmeister 1839

Tipos: alado (MCZ) não examinado; alado (MLU) não examinado.

Localidade tipo: BRASIL. Rio Grande do Sul: Porto Alegre.

Descrição: ver Aparatermes cingulatus na seção 4.4.

Material examinado:

-AMNH (não é tipo, um alado e dois operários). Metatype. Topotype. ?det. redet. + comp. A Emerson with type Im. MCZ, Puerto Alegre, Rio Grande do Sul, Brazil. 1 Im (fem) from Holmgren. Smaller sp. removed.

-USNM- (não é tipo, um operário ressecado e um alado)- USNM 71- Buenos Aires, Argentina, 60 .

Comentários: Os síntipos dessa espécie são alados montados secos depositados no MCZ e MLU sem condições de estudo. A amostra depositada no AMNH foi comparada por Emerson com o síntipo do MCZ, e é da localidade tipo.

4.3.18. Aparatermes silvestrii (Emerson, 1925): 421-423

(Tabs. 10, 11; Figs. 100-107)

Tipos: rainha primária, operários (CMNH) examinados.

Localidade tipo: GUIANA. Cuyuni-Mazaruni: Bartica, Kartabo. 
Rainha primária (Figs. 100-101): região mais clara entre o ocelo e a antena; fontanela grande (0,26 mm), arredondada, proeminente, visível em vista lateral (Fig. 100-101); mandíbula não examinada; pronoto subpentagonal, com a largura máxima menor que a largura da cabeça, margem anterior reta sem uma incisão central, margem posterior com uma reentrância central (Fig. 100-101); cápsula cefálica com cerdas longas esparsas e cerdas medianas (Fig. 100); pronoto com cerdas e pelos curtos por toda a placa; tergitos e esternitos com cerdas curtas e pelos curtos cobrindo o centro das placas; coxas com número variável de cerdas longas em riste, e tíbias com duas fileiras de cerdas grossas (Fig. 100); coloração da cápsula cefálica castanha escura (Fig. 100-101), manchas frontais pouco mais claras que o restante da cápsula cefálica com margens pouco definidas (Fig. 101); fontanela mais clara que o restante da cápsula cefálica (Fig. 101); pronoto pouco mais claro que a cápsula cefálica.

Operário (Figs. 102-107): fontanela pequena, arredondada a elipsoide (Fig. 103); mandíbula esquerda com ponta do dente apical mais curto em relação à ponta de M1+2; M3 triangular com margens assimétricas (Fig. 104); órgãos deiscentes inconspícuos (ver comentários); fêmur com face ventral plana; tíbia não inflada (Fig. 102); válvula entérica inerme, com seis pregas simétricas subovaladas, porção central das pregas com escamas pequenas com ápices pontiagudos voltados para a pança, margens lisas, e escamas maiores ao redor, de mesmo formato (Figs. 106-107); fontanela esbranquiçada (Fig. 103).

Comentário: Na tese de Acioli (2007), há indicação de que os operários possuem órgãos deiscentes conspícuos, o que não pode ser observado nos operários do parátipo do MCZ. Ver a seção ‘comparações' para o Gênero 11.

Material Examinado:

-CMNH (uma rainha primária e vários operários). Speculitermes silvestrii (Emerson). Paratype. "Anoplotermes (A)" det. A. Emerson. Brit. Guiana, Kartabo. 24.vi.1920. \#139. Queen. Nymphs. 


\subsection{Descrições e redescrições das espécies de Apicotermitinae da Mata Atlântica}

\subsubsection{Anoplotermes Müller 1873:347}

(Tabs. 8, 9; Figs. 12-24; 34; 46-56; 63-74; 316-317)

Espécie tipo: Anoplotermes pacificus Müller 1873:347, por monotipia.

Alado $(12-13,18,46-48,51,56,63-64,66)$ : margem dorsal da cápsula cefálica convexa em perfil (Figs. 12, 46, 63); fontanela arredondada a elipsoide (podendo estar inconspícua em alguns espécimes), localizada numa região deprimida do vértice (Figs. $13,47,64)$, mancha mediana arredondada a elipsoide; proeminente; margem entre o pós-clípeo e cápsula cefálica côncava (Figs. 13, 47, 64); olhos grandes (Figs. 13, 47, 64. Mandíbula esquerda (Figs. 18, 51, 66) com ponta do dente apical na mesma altura que a de M1+2, M3 triangular a arredondado, processo pré-molar conspícuo muito próximo da margem do M3, processo molar oculto pela proeminência molar; com ponta do dente apical na mesma altura que a de M1 ou pouco mais proeminente. Pronoto subhexagonal, subquadrangular, ou em forma de semicircunferência (Fig. 47, 64), com a largura máxima igual ou menor que a largura da cabeça com os olhos, margem anterior com uma incisão central discreta, com uma ligeira elevação na área central, como uma pequena sela, vista de perfil; cápsula cefálica com uma densa cobertura de cerdas de mesmo comprimento e pelos curtos (Figs. 12, 46, 48, 63); pronoto com cerdas e pelos curtos; tergitos e esternitos com cerdas curtas e pelos curtos cobrindo o centro das placas. Coloração da cápsula cefálica castanha escura; manchas frontais pouco mais claras que o restante da cápsula cefálica (Figs. 13, 47, 64) com margens pouco definidas; fontanela de cor variável; mancha mediana sempre da cor do restante da cápsula cefálica; pronoto pouco mais claro que a cápsula cefálica (Figs. 13, 47, 64).

Operário (Figs. 14-17, 19-24, 34, 49-56, 65, 67-74): margem dorsal da cápsula cefálica convexa em perfil (Figs. 14, 49, 65, 71); fontanela pequena, elipsoide, envolta nas manchas cerebrais (Figs. 15, 50); pós-clípeo de moderadamente inflado a inflado (Fig.s 14, 49, 65, 71). Mandíbula esquerda (Figs. 19, 52, 67, 72) com a ponta do dente apical proeminente em relação a ponta de M1+2; M3 triangular com as margens laterais formando ângulo reto/agudo; processo molar oculto pela proeminência molar. Sem órgãos deiscentes conspícuos; tíbia inflada (Figs. 17, 71). Tubo digestório com segmento 
misto presente; lingueta mesentérica longa, inflada (Fig. 16; 24, tubo digestório de referência para todas as espécies), íleo com calibre uniforme em toda extensão, formando um ' $\mathrm{C}$ ' invertido em vista ventral, terminando dorsalmente abaixo do colo (Fig. 24, vista dorsal, lateral direita; pode haver variação intracolonial em relação ao estado oculto do assentamento da válvula entérica, podendo ser total ou parcialmente oculto pelo colo); válvula entérica com armadura variável (Figs. 22-23, 34, 53-55, 69-70, 73-74) seis pregas simétricas com disposição das escamas centrais variável; assentamento da válvula entérica tubular, curto (Fig. 24). Cápsula cefálica com cobertura densa de cerdas de mesmo comprimento (Figs. 14, 49, 65, 71); pronoto com cerdas longas concentradas na margem do lobo anterior; tergitos e esternitos com cerdas medianas no centro das placas e cerdas longas nas laterais. Coloração da cápsula cefálica esbranquiçada (Figs. 14, 49, 65, 71); fontanela esbranquiçada (Figs. 15, 50).

Comparações: Ver comparações sob Humutermes (seção 4.4.19).

Anoplotermes banksi Emerson, 1925: 423-424

(Tab. 8,9; Figs. 12-24, 316)

Anoplotermes (Anoplotermes) banksi Emerson, 1925

Tipos: alado (AMNH), examinado; rainha primária, operários (CMNH), examinado. Localidade tipo: GUIANA. Cuyuni-Mazaruni: Bartica, Kartabo.

Alado (Figs. 12-13, 18): fontanela arredondada a inconspícua (Fig. 13); mancha mediana elipsoide. Pronoto em forma de semicircunferência. Demais características como o descrito para o gênero.

Operário (Figs. 14-17, 19-24): válvula entérica inerme (Figs. 22, 23), com seis pregas simétricas com a porção proximal bojuda e a porção distal alongada, escamas subhexagonais, as centrais não estriadas e concêntricas, com margens lisas, as escamas periféricas e interpregas estriadas. Demais características como descrito para o gênero.

Material Examinado (Fig. 316): BRASIL. Alagoas: Quebrangulo, lat 9,2288S, long 36,4259W, A Vasconcelos col., 19.vi.2000, MZUSP 13696. Bahia: Ilhéus, lat 14,8039S, 
long 39,0455W, C Bordereau col., xi.2000, MZUSP 22693 (a); Mata da Esperança, EM Cancelo e C Bordereau col., 16.xi.2000, MZUSP 22688; YT Reis col., 14.xi.2000, MZUSP 12483 (a); 23.v.2001, MZUSP 13769; 24.v.2001, MZUSP11980, 15.xi.2003, MZUSP 12460; Porto Seguro, Estação Ecológica do Pau-Brasil (ESPAB), lat 16,3831S, long 39,1666W, YT Reis col., 22.i.2003, MZUSP 12489; lat 16,4705S, long 39,2384W, JP Constantini col., 18.xi.2016, MZUSP 26656; Una, lat 15,269S, long 39,0471W, NCCP Barbosa col., MZUSP 26644. Espírito Santo: Pedro Canário, lat 18,2356S, long 39,8262W, JP Constantini col., 20.xi.2016, MZUSP 26627. Paraíba: João Pessoa, Mata do Buraquinho, lat 7,1480S, long 34,8614W, A Vasconcellos col., 01-20.vi.2000, MZUSP11975, 11976, 11977, 12707. Pernambuco: Recife, lat 7,9999S, long 34,9473W, EM Cancello col., i. 1980, MZUSP 8046; 29.i.1980, MZUSP 8022; BR232, RL Araujo col., 12.vii.1974, MZUSP 5468; Horto Dois Irmãos, lat 7,9999S, long 34,9473W, 04-08.vii.2000, MZUSP 11979, 13692, 13693, 13694. Sergipe: Santa Luzia do Itanhy, Mata do Crasto, lat 11,3633S, long 37,4155W, YT Reis e EM Cancello col., 30.vii.2001, MZUSP11996. GUIANA FRANCESA. Cuyuni-Mazaruni: Bartica, lat 6,3973N, long 58,6266W, A Emerson col., 13.v.1924(?), parátipo, $\mathrm{CMNH}(\mathrm{pq})$.

Notas de campo: solo; galhos caídos; na base do ninho de Labiotermes, em grande quantidade logo abaixo da serapilheira, defecavam como forma de defesa; ninho na base de uma árvore; ninho em pé de uma árvore, com um palmo de altura, muito duro; câmara real fica bem no centro do ninho e mede quatro centímetros de largura por um centímetro de comprimento; a rainha e o rei foram coletados juntos com uma quantidade enorme de ovos; este ninho era muito populoso; as galerias estendiam-se por quase toda árvore; em tronco apodrecido preenchido por solo, com alados.

\section{Anoplotermes meridianus Emerson 1925}

(Tab. 19, 20; Figs. 35-45, 328)

Alado (Figs. 35-36, 40, 45): cápsula cefálica convexa em perfil (Fig. 35); fontanela arredondada a elipsoide (Fig. 36), sem dimorfismo sexual; mancha mediana arredondada e proeminente (Fig. 36); margem entre o pós-clípeo e cápsula cefálica côncava (Fig. 36). Mandíbula esquerda (Fig. 40) com o dente apical proeminente em relação à M1+2, margem posterior do dente apical côncava, M3 arredondado; processo 
pré-molar conspícuo próximo do M3, processo molar oculto pela proeminência molar. Pronoto em forma de semicircunferência, com a largura máxima menor que largura da cabeça com os olhos, margens anterior e posterior com uma incisão central discreta, fêmeas pouco maiores que os machos (Fig. 45). Cápsula cefálica com uma densa cobertura de cerdas curtas e pelos curtos (Fig. 35); pronoto com cerdas e pelos curtos por toda a placa (Fig. 35); tergitos e esternitos com cerdas curtas e pelos curtos cobrindo o centro das placas, nos esternitos cerdas mais longas concentradas na margem posterior das placas; coxas anteriores com três a quatro cerdas longas, cerdas curtas e pelos, tíbia anterior com cerdas grossas, desorganizadas, na face interna e uma série de cerdas curtas e pelos. Coloração da cápsula cefálica castanha-alaranjada (Figs. 35-36); fontanela e manchas frontais mais claras que o restante da cápsula cefálica (Fig. 36); pronoto pouco mais claro que a cápsula cefálica (Fig. 36).

Operário (Figs. 37-39, 41-44): mandíbula esquerda (Fig. 41) com ponta do dente apical na mesma altura que a de M1+2, M3 triangular com uma região central ressaltada e margens assimétricas; processo molar semioculto pela proeminência molar; proeminência molar pouco desenvolvida; segmento misto presente (Fig. 44), com lingueta mesentérica curta inflada (Fig. 44, vista ventral); íleo terminando dorsalmente (Fig. 44, vista dorsal, lateral direita); válvula entérica inerme (Fig. 42-43), com seis pregas simétricas, com uma porção proximal bojuda e uma porção distal alongada, escamas arredondadas de margens lisas na porção bojuda, escamas maiores, subpoligonais, com margens ornamentadas lisas, na porção alongada das pregas; escamas da região interpregas subpoligonais, com margens ornamentadas com espinhos; assentamento da válvula entérica trilobado. Demais características como descrito para o gênero Longustitermes em Bourguignon et al., 2010.

Material Examinado (Fig. 328): BRASIL. Alagoas: Quebrangulo, lat 9,2288S, long 36,4259W, s. col., s. d., MZUSP 12461. Bahia: Conde, lat 11,7718S, long 37,7301, NCCP Barbosa col., 15.xi.2016, MZUSP 26639; Ilhéus, Ceplac, Mata Zoobotânica, lat 14,8039S, long 39,0455W, YT Reis col., 15.i.2001, MZUSP 13761, 13763; Mata de São João, Imbassaí, lat 12,5067S, long 37,9893, JP Constantini col., 15.xi.2016, MZUSP 26659; Mata de São João, Reserva Ecológica de Sapiranga, lat 12,5677S, long 38,0367W, YT Reis e EM Cancello col., 23.vii.2001, MZUSP 12493, 12494; 26.vii.2001, MZUSP 11998, 11999, 
12491, 12492, 12495. Espírito Santo: Pedro Canário, lat 18,3557S, long 39,8445W, JP Constantini col., 20.xi.2016, MZUSP 26624, 26625, 26626; 21.xi.2016, MZUSP 26630 (a); Santa Teresa, lat 19,9078S, long 40,5414W, RG Santos col., 27.xii.2014, MZUSP 24557; Sooretama, Reserva Biológica de Sooretama, lat 18,9897S, long 40,038W, LCM Oliveira, 09.iv.2001, MZUSP 12463; RG Santos col., 25.xi.2014, MZUSP 24559; 26.xi.2014, MZUSP 24549; AF Santos col., 26.xi.2014, MZUSP 24555. Paraíba: João Pessoa, Mata do Buraquinho, lat 7,1480S, long 34,8614W, 01-20.vi.2000, A Vasconcellos col., MZUSP 11974, 11978, 12708, 12711, 13486, 13487, 13488, 13489, 13490, 13491, 13492; Reserva Biológica Guaribas, lat 6,7318S, long 35,1487W, 23.x.2015, MZUSP 24548. Paraná: Tijucas do Sul, São João do Piraí, lat 25,8656S, long 48,9864W, AF Santos col., 22.v.2015, MZUSP 25608; TF Carrijo col., 22.v. 2015, MZUSP 24700. Pernambuco: Arcoverde, lat 8,4172S, long 37,0621W, EM Cancello col., 25.i.1990, MZUSP 8047. Rio de Janeiro: Itaguaí, Universidade Rural, lat 22,7685S, long 43,6850W, A Paraconi col., 03.xi.1969, MZUSP 4740 (a); Santa Maria Madalena, lat 21,9522S, long 42,0148W, JP Constantini col., 24.xi.2016, MZUSP 26663, 26667; Parque Estadual do Desengano, lat 21,8977S, long 41,9137W, LCM Oliveira col., 05.x.2001, MZUSP 12183. Rio Grande do Sul: Pântano Grande, lat 30,1907S, long 52,3735, RG Santos col., 26.v.2015, MZUSP 25043; São Leopoldo, lat 29,7693S, long 51,1459W, RG Santos col., 26.v.2015, MZUSP 24897, 25610, 25625. Santa Catarina: Blumenau, lat 26,8849S, long 49,0863W, RL Araujo col., 22.ii.1968, MZUSP 8045; Xanxerê, Posto Indígena, lat 26,8756S, long 52,4035W, RL Araujo col., 24.xii.1975, MZUSP 6483. São Paulo: Cajati, lat 25,0297S, long 48,5309W, RG Santos col., 21.v.2015, MZUSP 25654; Cananeia, Cachoeira do Pitu, lat 24,9101S, long 47,9983W, JP Constantini col., 04.i.2014, MZUSP 25888; Ilha do Cardoso, lat 25,1352S, long 47,9669W, LCM Oliveira col., 26.xi.2002, MZUSP 12177; São Paulo, lat 23,5504S, long 46,6333W, RL Araujo col., 30.viii.1944, MZUSP 2444. Sergipe: Santa Luzia do Itanhy, Mata do Crasto, lat 11,3633S, long 37,4155W, YT Reis e EM Cancello col., 31.vii.2001, MZUSP 11994.

Notas de campo: em tronquinho com areia; sob palmeira com muita serapilheira, solo com pouco húmus, mas com alguma umidade; tronco caído; associado à Heterotermes; solo arenoso; na base de ninho de Labiotermes; logo abaixo da serapilheira; no solo; ninho de Syntermes; em ninho abandonado de Cornitermes; ninho de Camponotus com Cornitermes; em ninho de formiga. 
Comentários: O operário de Anoplotermes meridianus compartilha com o operário de Longustitermes manni as seguintes características: segmento misto com lingueta mesentérica curta, dilatada (mas menos dilatada quando comparado a Anoplotermes), mesmo padrão da pilosidade da cápsula cefálica e corpo alongado. Conclui-se com base nisso que a espécie deve ser transferida no futuro para o gênero Longustitermes. Ver comentários sobre o tipo na seção 4.3 .

Anoplotermes pacificus Müller 1873: 347

(Tabs. 8, 9; Figs. 46-56, 316)

Anoplotermes indistinctus Snyder, 1926: 52, sinônimo júnior.

Tipos: alado (AMNH) examinado; alado (MCZ) não examinado; alado, operário (ZMB), não examinado.

Localidade tipo: BRASIL. Santa Catarina: Itajaí.

Alado (Figs. 46-48, 51, 56): fontanela arredondada a inconspícua (Fig. 47); mancha mediana arredondada. Pronoto subhexagonal (Fig. 47). Demais características como o descrito para o gênero.

Operário (Figs. 49-50, 52-56): válvula entérica inerme (Fig. 53-55), com seis pregas simétricas com a porção proximal bojuda e a porção distal alongada, escamas subquadrangulares, as centrais não estriadas e concêntricas, com margens ornamentadas com espinhos, as escamas periféricas e interpregas estriadas, com ou sem margens ornamentadas com espinhos (Fig. 53-54). Demais características como descrito para o gênero.

Material Examinado (Fig. 316): BRASIL. Espírito Santo: Santa Teresa, Reserva Biológica Augusto Ruschi, lat 19,9078S, long 40,5414W, NCCP Barbosa col., 22.xi2016, MZUSP 26638; Sooretama, Reserva Biológica de Sooretama, Trilha da Abóbora, lat 18,9897S, long 40,038W, NCCP Barbosa col., 25.xi.2014, MZUSP 24861; lat 19,0561S, long 40,1472W, 25.xi.2014, MZUSP 24552 (a); lat 19,0123S, long 40,1030W, 26.xi.2014, MZUSP 25476 (a). Paraná: Tijucas do Sul, lat 25,8656S, long 48,9864W, RG Santos col., 22.v.2015, MZUSP 25642; lat 25,8493, long 49,0406W, MZUSP 25582. Rio de Janeiro: Ilha de Cabo Frio, lat 22,9953S, long 41,9905W, Alceu e Arnaldo col., 17.xii.1965, MZUSP 
12081; Ilha Grande, lat 23,1552S, long 44,2325W, H Muth e H Sick col., 22.v.1944, MZUSP 3471; L Portela, col., 28.xi.1946, MZUSP 4589 (a); Petrópolis, lat 22,4715S, long 43,2108W, TF Carrijo col., 29.xi.2014, MZUSP 24554 (a); Santa Maria Madalena, Horto Florestal, lat 21,9522S, long 42,0148W, NCCP Barbosa col., 24.xi.2016, MZUSP 26633; Parque Estadual do Desengano, lat 21,8977S, long 41,9137W, 25.xi.2016, MZUSP 26637, 26643; LCM Oliveira col., 02.x.2001, MZUSP 12182. Santa Catarina: Anitápolis, lat 27,7657W, long 49,0393W, TF Carrijo col., 23.v.2015, MZUSP 25656; Blumenau, lat 26,8849S, long 49,0863W, RL Araujo col., 22.ii.1968, MZUSP 0361 (pq), 22.xii.1972, MZUSP 5207; Fritz Müller col., s.d., MZUSP 3472 (a); Parque das Nascentes do Ribeirão Garcia, lat 27,0537S, long 49,0858W, LCM Oliveira col, 19.x.2000, MZUSP 12184; 04.iii.2002, MZUSP 11614, 12181; 06.iii.2002, MZUSP 11613; 07.iii.2002, MZUSP 12180; F Silvestri col., s. d., MZUSP 1189; Cunha Porã, lat 26,8565S, long 53,1673W, NCCP Barbosa col., 29.v.2015, MZUSP 25617; Itapema, lat 27.096143S, long 48.6181W,RL Araujo e LR Fontes col., 19.vii.1978, MZUSP 7680 (a), 7785 (pq); 21.vii.1978, MZUSP 7684, 7781, 7782, 7783, 7784 (n); Joinville, lat 26,2078S, long 48,9152W, RG Santos col., 22.v.2015, MZUSP 25598; Lontras, lat 27,1675S, long 49,5599W, TF Carrijo col., 23.v.2015, MZUSP 25571; Xapecó, lat 27,0921S, long 52,6162W, RL Araujo col., 25.xii.1975, MZUSP 6472. São Paulo: Bertioga, Aldeia Rio Silveira, lat 23,7296S, long 45,8148W, s. col., s. d., MZUSP 10973; Cajati, lat 25,0297S, long 48,5309W, AF Santos col., 21.v.2015, MZUSP 25554; Cananeia, Parque Estadual Ilha do Cardoso, lat 25,1352S, long 47,9669W, LC Marques col., 27.xi.2002, MZUSP 12178 (a), 12179; Cubatão, Estação Raiz da Serra, lat 23,8266S, long 46,3611W, F Silvestri col., 28.viii.1908, MZUSP 1186 (a); s.d., MZUSP 1187 (pq, a); Ilhabela, Ilha da Vitória, lat 23,7507S, long 45,0164W, K. Lenko col., 17.iii.1964, MZUSP 12082; Itanhaém, lat 24,1993S, long 46,8705W, EM Cancello col., 9.iv.1980, MZUSP 8048; Cidade Santa Júlia, LR Fontes e SA Marques col., 717.i.1978, MZUSP 7548; LR Fontes e PS Terra col., 29.vii-03.viii.1978, MZUSP 7714 (pq); 7715 (pq); 29.xii.1978, MZUSP 7779 (a), 7781; 26.iii.1979, MZUSP 7825 (n), 7826 (pq), 7833; LR Fontes col., 25.xii.1978, MZUSP 7759, 7763; 16.vi.1979, MZUSP 7892, 7893, 7894; 16.ix.1979, MZUSP 7895; Peruíbe, lat 24,3277S, long 47,0020W, Fontes e PS Terra col., 15.ii.1979; Ribeirão Grande, Parque Estadual da Serra do Mar, Núcleo Intervales, LCM Oliveira col., 21.ii.2002, MZUSP 12218, 12219, 12220; 22.ii.2002, MZUSP 11386 (pq); LCM Oliveira e EM Cancello col., 14.ix.1999, MZUSP 11305, 12200, 12212, 12213, (pq), 12217; 16.ix.1999, MZUSP 12202, 12203, 12204, 12205, 12206, 12207, 12208, 
12209, 12210, 12211, 12214 (pq), 12215, 12216; 17.ix.1999, MZUSP 12201; Salesópolis, Estação Biológica de Boracéia, lat 23,6308S, long 45,8697W, RL Araujo col., 13.xi.1969, MZUSP 2171; CRF Brandão, F Ejchel, Johnson e Kovarick col., 17-18.xii.1992, MZUSP 10551; EM Cancello col., 30.ix.1989, MZUSP 9195, 9196, 9198 (pq); 01.x.1989, MZUSP 9199, 9200 (pq, n), 9201 (pq), 9202, 13744; BH Dietz e CI Yamamoto col., 14.vi.1997, MZUSP 10565; 12-17.vi.1997, MZUSP 10564, 10582 (pq, n); 14.vii.1997, MZUSP 10566 (pq, n); Expedição MZUSP, 05-06.viii.1983, MZUSP 10371; LR Fontes e PS Terra col, 24.i.1979, MZUSP 7765, 7766, 7767 (a); 26.i.1979, MZUSP 7775, 7776; T Schlemmermeyer col., ix.1995, MZUSP 10586, 10588 (pq, a), 10589, 10590 (pq), 10591, 10594 (pq, n), 10595, 10596 (pq), 10597, 10598 (n), 10599 (pq), 10600, 10601, 10602 (n), 10603 (pq, n), 10604, 10605 (pq, n), 10606, 10607 (n), 10624 (pq); v.1996, MZUSP 10583, 10584, 10585, 10587, 10592, 10593, 10715 (pq); vii.1996, MZUSP 10746; vi.1996, MZUSP 10714; 15.xii.1996, MZUSP 10716 (pq); 22.iv.1997, MZUSP 10608, 10613 (pq), 10615, 10654; 16.v.1997, MZUSP 10652 (pq); 04-05.x.1997, MZUSP 10610; xii.1997, MZUSP 10653; i.1998, MZUSP 10616; 10618; 10-20.ii.1998, MZUSP 15292 (pq), 15293, 15295 (pq, k), 15296 (pq), 15297 (pq), 15298 (pq), 15299 (pq), 15300, 15301, 15302 (pq), 15303 (pq), 15304, 15306, 15307, 15308, 15309, 15310, 15305; 22.ii.1998, MZUSP 10609, 10617, 10622; 23-26.ii.1998, MZUSP 10717; 9.iv.1998, MZUSP 10655 (pq), 10611 (pq, k); 21-24.iv.1998, MZUSP 10619; 20.x.1998, MZUSP 11822 (a) ; 1998, MZUSP 10573; sem data (entre 1995 e 1998) MZUSP 10612, 10614, 10620, 10621, 10623, 10976; 08.ii.2016, PIC Machado col., MZUSP 26431; Santo André, Alto da Serra, lat 23,7833S, long 46,3166W, M Kuhlman col., vi.1945, MZUSP 2881; Paranapiacaba, RL Araujo col., 13.v.1953, MZUSP 3836; 28.v.1953, MZUSP 4304(pq); Santo Antônio da Posse, Rio dos Couros, lat 22,6010S, long 46,921397W, RL Araujo col., 25.xi.1970, MZUSP 5402; São Paulo, lat 23,5504S, long 46,6333W, RL Araujo col., 08.viii.1944, MZUSP 2341; JVP Nogueira col., xi. 1949, MZUSP 3201 (a); Água Funda, s. col., 2.ix.1974, MZUSP 13741; Parque Estadual da Cantareira, JF Prado col., 14.viii.1958, MZUSP 1184 (pq, n); Volta Grande, Horto Florestal, MAJ Pereira, 16.ix.1993, MZUSP 11061, 11062, 11066, 11067, 11068, 11071,11072, 11075; 22.ix.1993, MZUSP 11064, 11070, 11073 (pq), 11074, 11079; 27.ix.1993, MZUSP 11060, 03.xi.1993, MZUSP 11077, 11080; 04.xi.1993, MZUSP 11078; 22.x.1993, MZUSP 11069; s.d., MZUSP 11067; Ipiranga, lat 23,5840S, long 46,6100W, LR Fontes col., 06.i.1978, MZUSP 7631; 09.viii.1978, MZUSP 7622 (n); F Silvestri col., MZUSP 1190, 1200, 1202 (pq); Jd. 
Botânico, MFL Françoso, Levs e Diniz col., 29.iii.1990, MZUSP 9282; São Sebastião, Praia de Boiçucanga, lat 23,7849S, long 45,6273W, EM Cancello col., 20.vii.1979, MZUSP 10864; Ubatuba, Parque Estadual da Serra do Mar, Núcleo Picinguaba, lat 23,3647S, long 44,8249W, F Esteves e R Feitosa col., 03-14.iii.2008, MZUSP 11817; LCM Oliveira col., 03.x.2000, MZUSP 12185, 12188, 12190, 12198; 04.x.2000, MZUSP 12187, 12191, 12194, 12197, 12199; 05.x.2000, MZUSP 12196; 18.x.2000, MZUSP 11483, 12186, 12192, 12193, 12195; 19.x.2000, MZUSP 12189.

Notas de campo: em tronquinho $(8 \times 40 \mathrm{~cm})$ embaixo da casca; bichos em árvore morta caída; no solo, no meio de emaranhado de raízes; na base de pteridófita - xaxim; ninho sobre o chão, a 200m da praia; ninho em árvore; no solo em cima de pedra; ninho arborícola, com Odontomachus; superfície do ninho esverdeada, com protuberâncias na parte superior, subcilíndricas; numa delas havia um alado; ninho preenchia todo samambaiaçu do ápice à base e se continuava dentro dos pecíolos, muitas raízes vivas, finas; ninho no chão, com muitas raízes dentro, aproximadamente um palmo de altura e meio de comprimento; com duas formigas; câmaras muito pequenas; ninho pequeno, com emaranhado de raízes finas, por dentro do ninho inteiro; há cápsulas cefálicas nas estruturas das paredes do ninho; câmaras muito pequenas.

\section{Anoplotermes sp. 1}

(Tabs. 8, 9; 63-70, 317)

Alado (Figs. 63-64, 66): fontanela elipsoide; mancha mediana arredondada. Pronoto subhexagonal (imagem deformado pela montagem/posição na Fig. 64). Demais características como o descrito para o gênero.

Operário (Figs. 65, 67-70): válvula entérica inerme (Fig. 69-70), com seis pregas simétricas com a porção proximal bojuda e a porção distal alongada, escamas subhexagonais, uniformes na porção bojuda, com margens ornamentadas com espinhos, escamas da porção alongada, mais compridas; escamas interpregas estriadas. Demais características como descrito para o gênero. 
Material Examinado (Fig. 317): BRASIL. Alagoas: Quebrangulo, lat 9,2288S, long 36,4259W, WO Almeida col., 20.vi.2000, MZUSP 13700; MP Silva col., 19.vi.2000, MZUSP 13697; A Vasconcellos col., 19.vi.2000, MZUSP 13698; 21.vi.2000, MZUSP 13701; YT Reis e EM Cancello col., 01.viii.2001, MZUSP 11982. Bahia: Ilhéus, Ceplac, Mata Zoobotânica, lat 14,8039S, long 39,0455W, EM Cancello e MT Ponte col, 16.i.2001, MZUSP 13757; YT Reis col., 23.v.2001, MZUSP 13767 (pq); 02.x.2001, MZUSP 13759; 03.x.2001, MZUSP 13760, 13765, 13766; 04.x.2001, MZUSP 13764 (pq); 11.i.2001, MZUSP 13762; Mata Boa Esperança, YT Reis col., 16.xi.2000, MZUSP 11981; Porto Seguro, lat 16,4705S, long 39,2384W, JP Constantini col., 18.xi.2016, MZUSP 26649 (a), 26653, 26654, 26658; ESPAB, lat 16,3831S, long 39,1666W, YT Reis col., 24.i.2003, MZUSP 12488. Espírito Santo: Pedro Canário, lat 18,3557S, long 39,8445W, JP Constantini col., 21.xi.2016, MZUSP 26675 (a); Sooretama, Reserva Biológica de Sooretama, lat 18,9897S, long 40,038W, NCCP Barbosa col., 24.xi.2014, MZUSP 24890; 26.xi.2014, MZUSP 24882 (a); EM Cancello e LCM Oliveira col., 07.iv.2001, MZUSP 11992; TF Carrijo col., 26.xi.2014, MZUSP 26911; LCM Oliveira, 04.vi.2001, MZUSP 11986; 05.iv.2001, MZUSP 11991; 06.iv.2001, MZUSP 11985, 11987, 11988, 11989; 09.iv.2001, MZUSP 11984, 11990; RG Santos col., 25.xi.2014, MZUSP 25514, 26.xi.2014, MZUSP 24553, 24565(a), 24568, 24872. Paraíba: João Pessoa, Mata do Buraquinho, lat 9,2288S, long 36,4259W, A Vasconcellos col., 01-20.vi.2000, MZUSP 12709. Pernambuco: Vicência, lat 7,6572S, long 35,3241W, Expedição ABC-MZUSP, 4.vi.1971, MZUSP 8182. Sergipe: Santa Luzia do Itanhy, Mata do Crasto, lat 11,3633S, long 37,4155W, YT Reis e EM Cancello col., 01.viii.2001, MZUSP 11983.

Notas de campo: tronco; ninho em solo; argila na base da árvore; solo; tronco em pé; ninho caído e abandonado; no solo e na serapilheira ao redor de árvore; no solo e na serapilheira abaixo de tronco caído.

\section{Anoplotermes sp. 2}

(Tabs. 8, 9; Fig. 71-74, 317)

Alado: Desconhecido. 
Operário (Figs. 71-74): válvula entérica armada (Fig. 73-74), com seis pregas simétricas com a porção proximal bojuda e a porção distal alongada, escamas subquadrangulares, as centrais não estriadas e concêntricas, com margens ornamentadas com espinhos; escamas periféricas e interpregas estriadas, com margens ornamentadas com espinhos; porção armada com seis placas simétricas com três a quatro espinhos de base larga, curtos. Demais características como descrito para o gênero.

Material Examinado (Fig. 317): BRASIL. Espírito Santo: Sooretama, Reserva Biológica de Sooretama, lat 18,9897S, long 40,0380W, TF Carrijo col., 25.xi.2014, MZUSP 25467.

Notas de campo: Em galho caído com bastante terra.

Comparações:

Todas as espécies em Anoplotermes possuem morfologia externa homogênea, com diferenças apenas na fontanela dos alados que pode ser elipsoide em Anoplotermes pacificus, Anoplotermes sp 1 e arredondada em Anoplotermes banksi. Em todos os alados o padrão de dentição das mandíbulas se mantém. A característica diagnóstica para as espécies de Anoplotermes é a válvula entérica, que em todas as espécies possui uma porção proximal bojuda e uma porção dista alongada, tendo um padrão de reticulação particular (Figs. 22-23, 34, 53-55, 69-70,73-74).

Os operários de Anoplotermes janus (Fig. 34), Anoplotermes parvus e Anoplotermes sp. 2 (Figs. 73-74) possuem uma porção extrovertida na luz da pança, armada, enquanto as outras espécies são inermes. A porção extrovertida da válvula entérica é semelhante entre Amplucrutermes inflatus e Anoplotermes sp. 2, sendo no entanto a porção central da prega muito diferente, bem como o padrão de enrolamento do tubo digestório. 0 operário de Anoplotermes janus possui de 1-2 espinhos muito esclerotizados em três das pregas, e o operário de Anoplotermes parvus possui uma grande placa muito esclerotizada.

\subsubsection{Aparatermes Fontes 1986}

(Tabs. 10, 11; Figs. 81-99, 318, 319)

Espécie tipo: Anoplotermes cingulatus abbreviatus Silvestri 1901, por designação original. 
Alado (Figs. 81-82, 88-89): cápsula cefálica mais larga que comprida em vista dorsal (Figs. 82, 89); região mais clara entre o ocelo e a antena; fontanela (Figs. 82, 89) inconspícua a conspícua, arredondada, pequena; olhos pequenos; ocelos proeminentes. Mandíbula esquerda com a ponta do dente apical proeminente em relação à M1+2, M3 triangular; região entre M3 e processo molar em forma de lâmina; processo pré-molar inconspícuo; processo molar oculto pela proeminência molar. Pronoto subhexagonal, com a largura máxima menor que a largura da cabeça, margem com uma incisão central, com uma ligeira elevação na área central, como uma pequena sela, vista de perfil, margem posterior também com uma reentrância central. Cápsula cefálica com uma densa cobertura de cerdas longas e pelos curtos (Figs. 81, 88). Pronoto com cerdas e pelos curtos por toda a placa; tergitos e esternitos com cerdas curtas e pelos curtos cobrindo o centro das placas (Figs. 81, 88). Coloração da cápsula cefálica castanhaalaranjada, manchas frontais pouco mais claras que o restante da cápsula cefálica com margens pouco definidas; fontanela mais clara que o restante da cápsula cefálica (Fig. 82, 89); pronoto pouco mais claro que a cápsula cefálica.

Operário (Figs. 83-87, 90-99): fontanela inconspícua envolta nas manchas cerebrais (Figs. 84, 91); pós-clípeo moderadamente inflado (Figs. 83, 90-92); mandíbula esquerda (Figs. 85, 95) com a ponta do dente apical pouco proeminente em relação à M1+2, M3 triangular com as margens assimétricas; região entre M3 e a proeminência molar formando uma margem reta; processo molar oculto pela proeminência molar, proeminência molar desenvolvida, sem estrias; órgãos deiscentes translúcidos in vivo, inconspícuo no animal fixado; tíbia não inflada a moderadamente inflada; tubo digestório sem segmento misto (Fig. 97); íleo terminando dorsalmente abaixo do colo (Fig. 97, vista dorsal); válvula entérica inerme (Figs. 86-87, 96-99) com seis pregas simétricas subovaladas, porção central das pregas com escamas pequenas subhexagonais com ápices pontiagudos voltados para o íleo, margens lisas, e escamas ao redor de mesmo formato, maiores; assentamento da válvula entérica trilobado, lobos bem pequenos quase inconspícuos, ocultos pelo colo em vista dorsal; cápsula cefálica com cerdas longas e medianas (Figs. 83, 90, 92), com cobertura relativamente uniforme; pronoto com cerdas longas concentradas na margem do lobo anterior; tergitos e esternitos com cerdas curtas no centro das placas; coloração da cápsula cefálica amarelada à alaranjada (Figs. 83-84, 90-93); fontanela esbranquiçada (Figs. 84, 91, 93). 
Comparações: ver comparações sob o Gênero 11 (seção 4.4.15).

Aparatermes abbreviatus (Silvestri, 1901): 8

(Tabs. 10, 11; Figs. 81-87, 318)

Alado (Figs. 81-82): fontanela bem destacada, arredondada (Fig. 82). Coxa com uma cerda em riste e um número pequeno de cerdas longas nas tíbias. Demais características como o descrito para o gênero.

Operário (Figs. 83-87): tíbia anterior moderadamente inflada. Coxas com 3-4 cerdas em riste, tíbias densamente cobertas por cerdas de diferentes comprimentos. Demais características como o descrito para o gênero.

Material Examinado (Fig. 318). BRASIL. Santa Catarina: Indaial, lat 26,8956S, long 49,2297W, NCCP Barbosa col., 23.v.2015, MZUSP 25616. São Paulo: Osasco, Praça da Padroeira, lat 23,5353S, long 46,7740W, D Polizello col., 15.vi.2016, MZUSP 24499; Salesópolis, Estação Biológica de Boraceia, lat 23,5827S, long 45,8347S, S Nihei col., 21.v-28.vi.2008, MZUSP 26920; T Schelemmermeyer col., v.1996, MZUSP 10670; vii.1996, MZUSP 10671; iv.1998, MZUSP 10987.

Comentários: ver comentários sobre o tipo na seção 4.3.

Notas de campo: Em ninho no solo.

Aparatermes cingulatus (Burmeister 1839): 767-768

(Tabs. 10, 11; Figs. 88-99, 319)

Termes cingulatus Burmeister 1839

Alado (Figs. 88-89): fontanela pouco conspícua, arredondada, confundindo-se com as áreas claras de inserção das cerdas (Fig. 89); coxa com 4-5 cerdas em riste, tíbias com um número grande de cerdas longas. Demais características como o descrito para o gênero. 
Operário (Figs. 90-99): tíbia anterior não inflada à moderadamente inflada. Coxas com 4-5 cerdas em riste. Demais características como o descrito para o gênero.

Material Examinado (Fig. 319): BRASIL. Santa Catarina: Lontras, lat 27,1675S, long 49,5599W, RG Santos col., 23.v.2015, MZUSP 25542. São Paulo: Salesópolis, Estação Biológica de Boraceia, lat 23,5744S, long 45,8396W, RL Araujo col., 13.xi.1969, MZUSP 2169, 2170; BH Dietz e CI Yamamoto col., 12-17.vi.1997, MZUSP 10667; T Schelemmermeyer col., 18.vii.1996, MZUSP 10668; 15.xii.1996, MZUSP 10985; s. d., MZUSP 10668, 10669; 16.v.1997, MZUSP 10795. Rio Grande do Sul: Eldorado do Sul, lat 30,0621S, long 51,5326W, TF Carrijo col., 26.v.2015, MZUSP 25533; Pelotas, lat 31,7145S, long 52,3294W, ALCI col., 14.iv.1993, MZUSP 13743; São Leopoldo, lat 29,7625S, long 51,1331W, TF Carrijo col., 26.v.2015, MZUSP 25579.

Notas de campo: no solo; em tronco podre.

Comparações:

Foram estudadas amostras de Aparatermes abbreviatus e Aparatermes cingulatus depositadas no AMNH e USNM para determinação das duas espécies e consequente comparação com o material alvo deste estudo (veja comentários na seção 4.3). A principal diferença entre as duas espécies está na fontanela dos alados, casta ausente no material da Mata Altântica.

Dessa forma dados morfométricos e a comparação da pilosidade da cabeça, coxa e tíbia dos operários foram utilizadas para a separação dos dois grupos de amostras, sendo (como o nome já indica) Aparatermes abbreviatus a espécie com menor largura da cabeça e também pilosidade menos densa quando comparada com Aparatermes cingulatus (Tab. 10, 11).

4.4.3. Compositermes Scheffrahn 2013: 382-384

(Tabs. 12, 13; Figs. 108-116, 322)

Espécie tipo: Compositermes vindai Scheffrahn 2013, por designação original. 
Rainha primária (Figs. 108-109): cápsula cefálica ligeiramente convexa em perfil (Fig. 108); manchas frontais fracamente delimitadas confundem-se com as manchas de inserção das cerdas (Fig. 109); fontanela arredondada, pequena, se diferencia das manchas de inserção das cerdas pela margem bem definida e escura (Fig. 109); mancha mediana pequena, arredondada e proeminente; margem do pós-clípeo com cápsula cefálica côncava (Fig. 109); mandíbula não examinada; pronoto em forma de semicircunferência, com a largura máxima igual ou menor a largura da cabeça com os olhos, margem anterior com reta sem incisão central discreta, com uma ligeira elevação na área central, como uma pequena sela, vista de perfil; cápsula cefálica com uma densa cobertura de cerdas longas e medianas e pelos (Fig. 108); pronoto com cerdas e pelos em toda a extensão da placa e cerdas mais longas nas margens anterior e posterior; abdômen fisogástrico coberto por pelos, sem destaque; tíbias anteriores com duas fileiras com 5-6 cerdas grossas (Fig. 108); coxas e demais tíbias com cerdas longas de diferentes comprimentos e pelos. Coloração da cápsula cefálica castanha-alaranjada (Figs. 108-109), manchas frontais e inserção das cerdas pouco mais claras que o restante da cápsula cefálica com margens pouco definidas; fontanela esbranquiçada com margem castanha escura; pronoto pouco mais claro que a cápsula cefálica (Figs. 108-109).

Operário (Figs. 110-116): íleo terminando dorsalmente (Fig 116, vista dorsal). Demais características como descrito em Scheffrahn, 2013.

Compositermes vindai Scheffrahn, 2013

(Tabs. 12, 13; Figs. 108-116, 322)

Tipos: operário (FTDL)

Localidade tipo: TRINIDAD E TOBAGO. Trinidad: Mount Saint Benedict

Alado (Figs. 108-109): Como descrito para o gênero.

Operário (Figs. 110-116): Como descrito em Scheffrahn (2013).

Material Examinado (Fig. 322): BRASIL. São Paulo: São Paulo, Ipiranga, lat 23,5866S, long 46,6095W, Luederwaldt col., 25.viii.1909, MZUSP 1909(pq). Rio Grande do Sul: São 
Leopoldo, lat 29,2168S, long 54,8435W, RG Santos col., 25.v.2015, MZUSP 25678; TF Carrijo col., 26.v.2015, MZUSP 25747.

Notas de campo: Ninho de Camponotus (?), com Cornitermes; em ninho de formiga com outras espécies de Apicotermitinae.

Comparações: o operário de Compositermes é facilmente reconhecível, pois possui uma estrutura exclusiva, uma válvula entérica alongada com placas esclerotizadas, no final do assentamento da válvula entérica.

\subsubsection{Disjunctitermes Scheffrahn 2017: 74}

(Tabs. 12, 13; Figs. 117-131, 330)

Espécie tipo: Disjunctitermes insularis Scheffrahn em Scheffrahn et al., 2017: 77, por monotipia.

Alado (Figs. 117-118, 121, 125-126, 129): fontanela arredondada (Fig. 118, 126), sem dimorfismo sexual; mandíbula esquerda (Figs. 121, 129) com a ponta do dente apical proeminente em relação à M1+2; M3 triangular; processo pré-molar conspícuo e processo molar não oculto pela proeminência molar; proeminência molar pouco desenvolvida; pronoto subpentagonal a subquadrangular (Fig. 118, 126), com a largura máxima menor que a largura da cabeça, margem anterior variável com uma incisão central discreta, sem emarginados marcantes, linha central muito evidente; cápsula cefálica com densa cobertura de cerdas longas e medianas e pelos curtos (Figs. 117, 125); pronoto com cerdas e pelos curtos; tergitos e esternitos com cerdas curtas e pelos curtos cobrindo o centro das placas uniformemente; tíbias com cerdas grossas dispostas desordenadamente. Coloração da cápsula cefálica castanho-alaranjada a castanhoescura (Figs. 117-118, 125-126), manchas frontais pouco mais claras que o restante da cápsula cefálica com margens pouco definidas. Fontanela esbranquiçada. Pronoto mais claro que a cápsula cefálica. Pilosidade da pleura alaranjada nas fêmeas.

Operário (Figs. 119-20, 122-124, 127-128, 130-131): fontanela arredondada (pouco visível nas imagens em vista dorsal); pós-clípeo moderadamente inflado (Figs. 119, 
127). Mandíbula esquerda (Figs. 122, 130) com ponta do dente apical na mesma altura que a de M1+2 ou mais proeminente, M3 triangular com as margens laterais formando ângulo reto/agudo, processo molar de posição variável podendo estar oculto ou não pela proeminência molar; sem órgãos deiscentes conspícuos; tíbia inflada; tubo digestório com segmento misto presente (Fig. 123, vista ventral); lingueta mesentérica partindo do lado esquerdo até o direito em vista ventral, porção final da lingueta não globulosa (Fig. 123, vista ventral); íleo terminando na lateral direita; válvula entérica inerme (Figs. 124, 131) com seis pregas simétricas com disposição e ornamentação das escamas variável; assentamento da válvula entérica trilobado (Fig. 123). Cápsula cefálica com densa cobertura de cerdas medianas (Fig. 119, 127); pronoto com cerdas longas concentradas na margem do lobo anterior e nas regiões arredondadas no lobo posterior; tergitos e esternitos com cerdas curtas no centro das placas; coloração da cápsula cefálica esbranquiçada (Figs. 119-120, 127-128); fontanela esbranquiçada (Figs. 120-128).

Comparações: ver comparações sob Humutermes (seção 4.4.19).

\section{Disjunctitermes sp. 1}

(Tabs. 12, 13; Figs. 117-124, 330)

Alado (Figs. 117-118, 121): pronoto subpentagonal; macho desconhecido; cápsula cefálica castanho-alaranjada (Figs. 117-118). Demais características como o descrito para o gênero.

Operário (Figs. 119-120, 122-124): válvula entérica inerme (Fig. 124), com seis pregas simétricas com a porção proximal bojuda e a porção distal curta, escamas subhexagonais, as centrais não estriadas e concêntricas, com margens lisas, as escamas periféricas e interpregas estriadas. Demais características como descrito para o gênero.

Material Examinado (Fig. 330): BRASIL. Bahia: Ilhéus, lat 14,8039S, long 39,0455W, C Bordereau e EM Cancello, 07.xi.2000, MZUSP 22690, 22691, 22694 (a).

Notas de campo: na areia na base de árvore. 


\section{Disjunctitermes sp. 2}

(Tabs. 12, 13; Figs. 125-131, 330)

Alado (Figs. 125-126, 129): pronoto subquadrangular (Fig. 126); cápsula cefálica castanho-escura (Figs. 125-126). Demais características como descrito para o gênero.

Operário (Figs. 127-128, 130-131): válvula entérica inerme (Fig. 131), com seis pregas simétricas, oblongas, escamas subhexagonais, de comprimento uniforme em toda a prega, com margens distais das escamas ornamentadas com espinhos. Demais características como descrito para o gênero.

Material Examinado (Fig. 330): BRASIL: São Paulo: São Bernardo do Campo, UFABC, próximo à área de agrofloresta, lat 23,6783S, long 46,5678W, JP Constantini, 09.i.2017, MZUSP 26708 (a).

Notas de campo: No solo próximo a ninho de Procornitermes lespesii.

Comparações:

O processo molar na mandíbula esquerda do operário, indicado na publicação de D. insularis como uma característica diagnóstica é variável nos espécimes examinados nas oito amostras (parátipos) recebidas como empréstimo, assim como nas amostras das duas outras espécies descritas aqui.

A válvula entérica é inerme nas três espécies e apresenta padrão variável de disposição das escamas, e os operários, assim como em D. insularis, possuem uma lingueta mesentérica longa, sem, no entanto uma porção globulosa, justificando o agrupamento dessas espécies no mesmo gênero.

Os alados das espécies Disjunctitermes sp. 1 e Disjunctitermes sp. 2 são muito parecidos e apresentam o processo pré-molar conspícuo; diferem no tamanho dos olhos, que é maior em Disjunctitermes sp. 1; na densidade da pilosidade na cápsula cefálica (mais denso em Disjunctitermes sp. 2); e na forma do M3 que é mais proeminente em Disjunctitermes sp. 2.

O operário de Disjunctitermes sp. 2 tem a pilosidade na cápsula cefálica mais densa comparado à Disjunctitermes sp. 1. 


\subsubsection{Gênero 1}

(Tabs. 15; Figs. 132-142, 318, 319)

Alado: Desconhecido.

Operário (Figs. 132-142): cápsula cefálica convexa em perfil (Fig. 132, 138-139); fontanela inconspícua à grande e arredondada (Figs. 133-140); mandíbula esquerda (Fig. 134, 141) com a ponta do dente apical pouco mais curto em relação à M1+2, M3 com as margens irregulares; região entre M3 e a proeminência molar formando uma margem reta, processo molar oculto pela proeminência molar; órgãos deiscentes conspícuos (pouco visíveis nas imagens disponíveis), em alguns espécimes com o conteúdo evertido, sem romper o envoltório abdominal; tíbia não inflada (Figs. 132, 138-139); pernas alongadas (Fig. 138); tubo digestório sem segmento misto (Fig. 135); íleo terminando dorsalmente (Fig. 135, vista dorsal); válvula entérica inerme (Fig. 136137, 142), com seis pregas simétricas subovaladas, porção central das pregas com escamas pequenas com ápices cônicos voltados para o íleo ou pança, margens lisas, e escamas maiores ao redor, de mesmo formato; assentamento da válvula entérica tubular; cápsula cefálica com cobertura densa de cerdas medianas e curtas (Figs. 132, 139); pronoto com cerdas longas concentradas nas margens do lobo anterior e posterior; tergitos e esternitos com cerdas curtas no centro das placas; fêmures com cerdas longas mais destacadas; coloração da cápsula cefálica amarelada (Figs. 132-133, 138-140); fontanela esbranquiçada (Fig. 140).

Comparações: ver comparações sob Gênero 11.

\section{Gên. 1 sp. ES2}

(Tabs. 15; Figs. 132-136, 319)

Operário (Figs. 132-136): fontanela inconspícua, porção central das pregas na válvula entérica mais ampla (Fig. 136-137), com escamas pequenas com ápices pontiagudos voltados para o íleo. Demais características como descrito para o gênero. 
Material Examinado (Fig. 319): BRASIL. Alagoas: Quebrangulo, lat 9,2288S, long 36,4259W, A Vasconcellos col., 20.vi.2000, MZUSP 13704; 21.vi.2000, MZUSP 13705; MP Silva col., 21.vi.2000, MZUSP 13706. Paraíba: João Pessoa, Mata do Buraquinho, lat 7,1480S, long 34,8614W, A Vasconcellos col., 01-20.vi.2000, MZUSP 13703. Espírito Santo: Sooretama, Reserva Biológica de Sooretama, lat 18,9966S, long 40,0149W, RG Santos col., 25.xi.2014, MZUSP 25456.

Notas de campo: no solo.

\section{Gên. 1 sp. S5}

(Tabs. 15; Figs. 138-142, 318)

Operário (Figs. 138-142): fontanela grande arredondada, porção central das pregas na válvula entérica com escamas pequenas com ápices pontiagudos voltados para a pança (Fig. 142). Demais características como descrito para o gênero.

Material Examinado (Fig. 318): BRASIL. Espírito Santo: Sooretama, Reserva Biológica de Sooretama, lat 18,9967S, long 40,1267W, TF Carrijo col., 26.xi.2014, MZUSP 26910.

Comparações: o operário da espécie Gên. 1 sp. S5 é menor quando comparado à Gên. 1 sp. ES2, além de ter pernas mais longas e diferenças na disposição de escamas com espinhos na porção central da prega na válvula entérica. Além disso, o operário de Gên. 1 sp. S5 tem fontanela conspícua.

\subsubsection{Gênero 2}

(Tabs. 14, 15; Figs. 143-155, 321)

Alado (Figs. 143-145, 148): fontanela da fêmea grande e arredondada (Fig. 144), fontanela do macho pouco conspícua situada em uma região deprimida da cápsula cefálica (Fig. 145); mancha mediana conspícua; mandíbula esquerda (Fig. 148) com a ponta do dente apical proeminente em relação a posição de M1+2, M3 triangular com as margens formando um ângulo agudo/reto; processo pré-molar inconspícuo; processo molar oculto pela proeminência molar; pronoto subtrapezoidal, muito mais largo que comprido (Fig. 145); margem anterior reta com uma incisão central discreta, com uma 
ligeira elevação na área central, como uma pequena sela, vista de perfil; cápsula cefálica densamente coberta de cerdas longas e pelos curtos (Fig. 143); pronoto com cerdas longas destacadas nas margens laterais em vista dorsal; cerdas longas nas margens da placa e pelos curtos cobrindo toda a placa (Fig. 143); tergitos e esternitos com cerdas curtas e pelos curtos cobrindo o centro das placas, em ambos os casos voltados para a região posterior, coloração da cápsula cefálica castanha escura (Figs. 143-145), manchas frontais pouco mais claras que o restante da cápsula cefálica com margens pouco definidas; fontanela da fêmea bem mais clara que a cápsula cefálica (Fig. 144), fontanela do macho pouco mais clara que o restante da cápsula cefálica (fig. 145); pronoto pouco mais claro que a cápsula cefálica (Figs. 144-145).

Operário (Fig. 146-147,149-155): fontanela mediana, arredondada (Fig. 147); pós-clípeo inflado (Fig. 146); mandíbula esquerda (Fig. 149) com ponta do dente apical na mesma altura que M1+2, M3 triangular com as margens laterais formando ângulo reto/agudo, processo molar oculto pela proeminência molar; órgãos deiscentes conspícuos, formando duas massas distintas organizadas, visíveis em sua forma plena apenas in vivo (Figs. 154-155), perdendo suas características com a conservação em ácool; tíbia não inflada; tubo digestório com segmento misto vestigial (Fig. 153, vista dorsal); íleo com calibre uniforme em toda extensão da alça terminando na lateral direita (Fig. 153); válvula entérica armada (Fig. 150-152), com seis pregas simétricas subovaladas, com escamas subpoligonais e um espinho central, escamas de margens lisas ou com pequenos espinhos; porção armada com seis placas assimétricas; três maiores, bem desenvolvidas, com espinhos nas margens, duas menores, pouco desenvolvidas com espinhos nas margens e uma vestigial; assentamento da válvula entérica tubular; cápsula cefálica coberta por cerdas em riste (Fig. 146), esparsas; pronoto com cerdas longas concentradas nas margens do pronoto; tergitos e esternitos com cerdas longas no centro das placas, nos tergitos, voltadas para a região posterior e nos esternitos parte delas voltadas para a região posterior e parte para a região anterior; coxas anteriores com uma cerda; coloração da cápsula cefálica amarelada (Figs. 146-147); fontanela esbranquiçada (Fig. 147).

Comparações: ver comparações sob Gênero 3. 


\section{Gên. 2 sp. MCH}

(Tabs. 14, 15; Figs. 143-155, 321)

Alado (Figs. 143-145, 148): Como descrito para o gênero.

Operário (Fig. 146-155): Como descrito para o gênero.

Material Examinado (Fig. 321): BRASIL. Espírito Santo: Itapemirim, lat 20,9433S, long 41,0527W, 23.xi.2016, MZUSP 26666; Pedro Canário, lat 18,2356S, long 39,8262W, JP Constantini col., 20.xi.2016, MZUSP 26622, 26628; lat 18,3557S, long 39,8445, JP Constantini col., 21.xi.2016, MZUSP 26632; Santa Teresa, Reserva Biológica de Augusto Ruschi, lat 19,9078S, long 40,5414, TF Carrijo col., 27.xi.2014, MZUSP 25871 (a); JP Constantini col., 22.xi.2016, MZUSP 26668, 26673; Sooretama, Reserva Biológica de Sooretama, lat 19,0123S, long 40,1030W, TF Carrijo col., 26.xi.2014, MZUSP 24875.

Notas de campo: no solo; solo bem úmido, muitos cupins sem sinal de ninfa ou reprodutores primários, difuso no solo; debaixo da turfa em solo escuro, bem úmido, apareceram alguns juvenis; com estrutura que parecia o ninho, com Hydrecotermes sp. 1; em raízes secas e ocas de uma palmeira.

\subsubsection{Gênero 3}

(Tabs. 15; Figs. 156-163, 326)

Alado: Desconhecido.

Operário (Figs. 156-163): fontanela mediana, arredondada; pós-clípeo fortemente inflado; mandíbula esquerda (Fig. 158) com dente apical proeminente em relação à M1+2, M3 triangular com as laterais formando ângulo reto/agudo, processo molar não oculto pela proeminência molar; sem órgãos deiscentes conspícuos; tíbia moderadamente inflada; tubo digestório com segmento misto vestigial (Fig. 163); íleo terminando na lateral direita (Fig. 163, vista lateral direita); válvula entérica armada (Figs. 159-162), com seis pregas simétricas subovaladas, com escamas subpoligonais e um espinho central, escamas de margens lisas; porção armada com seis placas assimétricas; três maiores, com espinhos nas margens que se encaixam, formando uma estrutura conjunta e três menores livres, com espinhos nas margens; assentamento da 
válvula entérica tubular; cápsula cefálica com cerdas longas, dispersas (Fig. 156); pronoto com cerdas longas concentradas nas margens (Fig. 156); meso e metanoto com cerdas longas nas margens; tergitos e esternitos com cerdas longas e cerdas curtas no centro das placas, nos esternitos cerdas longas voltadas para a região anterior; coxas anteriores com uma cerda longa; coloração da cápsula cefálica amarelada (Fig. 156-157), fontanela esbranquiçada (Fig. 157).

Comparações:

0 operário de Gên. 2 é parecido com o operário de Gên. 3 em relação ao enrolamento do tubo digestório e a pilosidade de cerdas esparsas na cápsula cefálica e na assimetria da válvula entérica (uma das pregas possui a região extrovertida reduzida).

No entanto, o Gên. 2 possui órgãos deiscentes conspícuos in vivo, característica não conhecida para o Gên. 3. 0 processo molar da mandíbula esquerda do operário está oculto no Gên. 2 e não oculto no Gên. 3. 0 alado do Gên. 3 é desconhecido, e uma vez descrito talvez possa contribuir para confirmar a hipótese de separação das espécies em dois gêneros.

\section{Gênero 3 sp. ORQ}

(Tabs. 15; Figs. 156-163, 326)

Operário (Figs. 156-163): Como o descrito para o gênero.

Material Examinado (Fig. 326): BRASIL. Espírito Santo: Sooretama, Reserva Biológica de Sooretama, lat 19,0046S, long 40,1488W, TF Carrijo col., 24.xi.2014, MZUSP 24141. Rio de Janeiro: Santa Maria Madalena, Horto Florestal, lat 21,9522S, long 42,0148W, NCCP Barbosa col., MZUSP 26642.

Notas de campo: No solo embaixo de tronco. 


\subsubsection{Gênero 4}

(Tabs. 14, 15; Figs. 164-172, 327)

Alado (Figs. 167-165, 168): margem dorsal da cápsula cefálica convexa em perfil (Fig. 164); fontanela pequena, arredondada, pouco conspícua nos dois sexos (Fig. 165); mancha mediana pouco conspícua; mandíbula esquerda (Fig. 168) com o dente apical proeminente em relação à M1+2, M3 com margens assimétricas; processo pré-molar aparente, pouco desenvolvido, processo molar semioculto pela proeminência molar; pronoto subpentagonal (Fig. 165), com a largura máxima menor que a largura da cabeça, com uma incisão central discreta, e uma ligeira elevação na área central, como uma pequena sela, vista de perfil (Fig. 164); pilosidade da cápsula com cobertura uniforme de cerdas longas e pelos (Fig. 164), com as bases destacadas (Fig. 165); pronoto com cerdas longas concentradas na margem anterior e nos dois terços posteriores da placa (Fig. 164), e pelos curtos em toda a placa; tergitos com cerdas curtas e pelos curtos, voltados posteriormente, cobrindo toda a placa; esternitos com cerdas curtas e pelos curtos, distribuídos em várias direções, cobrindo toda a placa; pro- e mesocoxas com poucas cerdas longas e densa cobertura de pelos, e metacoxas com grande densidade de cerdas longas e pelos curtos; fêmures com muitas cerdas longas na face interna; tíbias com cerdas grossas e longas na face interna, dispostas desorganizadamente, e pelos curtos; fêmea com concentração de pelos levemente destacados na região da pleura; coloração da cápsula cefálica castanha (Figs. 164-165), manchas frontais pouco mais claras que o restante da cápsula cefálica com margens pouco definidas; fontanela da mesma cor que o restante da cápsula cefálica (Fig. 165); pronoto pouco mais claro que a cápsula cefálica; pleura da fêmea com cerdas laranja-claro.

Operário (Figs. 166-167, 169-172): fontanela pequena, arredondada à elipsoide (Fig. 167); pós-clípeo moderadamente inflado (Fig. 166); mandíbula esquerda (Fig. 169) com a ponta do dente apical proeminente em relação à M1+2, M3 triangular com as margens laterais formando ângulo reto/agudo, processo molar oculto pela proeminência molar; sem órgãos deiscentes conspícuos; tíbia não inflada; tubo digestório (Fig. 172) sem segmento misto; íleo terminando ventralmente (Fig. 172, vista ventral); válvula entérica inerme (Fig. 170-171) com seis pregas simétricas subovaladas, porção central da prega forma uma bolsa evaginada, escamas subhexagonais com margens lisas; assentamento 
da válvula entérica tubular; cápsula cefálica com cobertura de cerdas medianas (Fig. 166); pronoto com cerdas longas concentradas nas margens do lobo anterior e posterior (Fig. 166); meso e meta com cerdas longas nas margens; tergitos e esternitos com cerdas curtas no centro das placas desorganizadamente distribuídas; coxas anteriores com cerdas grossas; coloração da cápsula cefálica esbranquiçada; fontanela esbranquiçada (Fig. 167).

Comparação: ver comparações sob Hydrecotermes.

\section{Gên. 4 sp. V1}

(Tabs. 14, 15; Figs. 164-172, 327)

Alado (Figs. 167-165, 168): Como descrito para o gênero.

Operário (Figs. 166-167, 169-172): Como descrito para o gênero.

Material Examinado (Fig. 327): BRASIL. Bahia: Ilhéus, Lagoa Encantada, lat 14,6217S, long 39,1403W, C Bordereau col., 09.xi.2000, 22687(a); 10.xi.2000, MZUSP 22689(a).

Notas de campo: No solo, na base de árvore.

\subsubsection{Gênero 5}

(Tabs. 16; Figs. 173-179, 332)

Alado: Desconhecido.

Operário (Figs. 173-179): fontanela mediana, arredondada a elipsoide (Fig. 174); pósclípeo moderadamente inflado (Fig. 173); mandíbula esquerda (Fig. 176) mandíbula esquerda com ponta do dente apical mais curto, ou na mesma altura em relação à ponta de M1+2; M3 triangular com as margens laterais formando ângulo reto/agudo; processo molar semioculto pela proeminência molar; órgãos deiscentes conspícuos (Fig. 175); tíbia não inflada (Fig. 173); tubo digestório sem segmento misto (Fig. 179, vista ventral); íleo terminando ventralmente (Fig. 179); válvula entérica armada (Fig. 177-178), com 
seis pregas assimétricas subovaladas, porção central da prega forma uma bolsa evaginada, com um espinho na ponta, escamas subhexagonais com margens lisas; três pregas com a região distal desenvolvida, com espinhos curtos; assentamento da válvula entérica tubular (Fig. 179, vista ventral); cápsula cefálica com cerdas longas e medianas, dispersas (Fig. 173); pronoto com cerdas medianas concentradas na margem do lobo anterior e posterior (Fig. 173); tergitos com cerdas medianas no centro das placas voltadas posteriormente e esternitos com cerdas medianas no centro das placas, parte voltadas posteriormente e parte voltadas anteriormente; coloração da cápsula cefálica esbranquiçada (Fig. 173); fontanela esbranquiçada (Fig. 174).

Comparações: ver comparações sob Ruptitermes bandeirai.

\section{Gên. 5 sp. V4}

(Tabs. 16; Figs. 173-179, 332)

Alado: Desconhecido.

Operário (Figs. 173-179): Como descrito para o gênero.

Material Examinado (Fig. 332): BRASIL. São Paulo: Salesópolis, Estação Biológica de Boraceia, lat 23,6308S, long 45,8697W, T. Schlemmermeyer col., xii.1999, MZUSP 11038.

\subsubsection{Gênero 6}

(Tabs. 16; Figs. 180-185, 326)

\section{Alado: Desconhecido}

Operário (Figs. 180-185): fontanela pequena, arredondada (Fig. 181); pós-clípeo fortemente inflado (Fig. 180); mandíbula esquerda (Fig. 183) com a ponta do dente apical proeminente em relação à $\mathrm{M} 1+2$, M3 triangular com as margens laterais formando ângulo reto/agudo, processo molar oculto/semi-oculto pela proeminência molar; tíbia inflada (Fig. 182); sem órgãos deiscentes conspícuos; tubo digestório com segmento misto presente (Fig. 184); lingueta mesentérica longa (Fig. 184, vista ventral); 
porção final da lingueta fortemente dilatada, globulosa (Fig. 184, vista ventral); íleo terminando na lateral direita (Fig. 184, vista lateral direita); válvula entérica inerme (Fig. 185), com seis pregas simétricas oblongas, escamas subhexagonais, com margens ornamentada com espinhos curtos, uniformes em toda a extensão da prega, escamas interpregas mais largas que compridas com margens ornamentadas com espinhos; assentamento da válvula entérica tubular (Fig. 184, vista lateral); cápsula cefálica com cobertura densa de cerdas medianas e cinco pares de cerdas longas distribuídas ao longo da cabeça (Fig. 180); pronoto com cerdas longas concentradas na margem do lobo anterior e posterior (Fig. 180); meso e metanotos com cerdas na margem posterior; cerdas dos pro-, meso- e metanoto mais longas e destacadas que as dos tergitos; tergitos com poucas cerdas curtas concentradas no centro da placa voltadas para a região posterior ou para cima; esternitos com cerdas mais longas que as dos tergitos; coloração da cápsula cefálica amarelada (Fig. 180); fontanela esbranquiçada (Fig. 181).

\section{Comparações:}

O operário da espécie Gênero 6 sp. S8, assim como as espécies de Anoplotermes também possui uma lingueta mesentérica dilatada, no entanto, é uma espécie muito maior que qualquer Anoplotermes (compare as medidas nas tabelas 8 e 16), com a margem dorsal da cápsula cefálica dorsoventralmente achatada, o íleo termina ventralmente e o padrão de escamas da válvula entérica é muito distinto do observado nas espécies de Anoplotermes. Optou-se por isso, por manter a espécie em um novo gênero. 0 exame do alado (desconhecido para Gên. $6 \mathrm{sp.} \mathrm{S8)} \mathrm{pode} \mathrm{dar} \mathrm{mais} \mathrm{indicações} \mathrm{se}$ esse é o melhor posicionamento da espécie.

\section{Gên. 6 sp. 58}

(Tabs. 16; Figs. 180-185, 326)

Alado: Desconhecido.

Operário (Figs. 180-185): Como descrito para o gênero.

Material Examinado (Fig. 326): BRASIL. Espírito Santo: Afonso Cláudio, lat 20,2374S, long 41,1761W, RG Santos, 28.xi.2014, MZUSP 24876; TF Carrijo col., 28.xi.2014, MZUSP 
24575. Rio Grande do Sul: Barrocada, lat 30,3231S, long 53,2384W, TF Carrijo col., 26.v.2015, MZUSP 24874; Eldorado do Sul, lat 30,0621S, long 51,5326W, TF Carrijo col., 26.v.2015, MZUSP 25621. Santa Catarina: Lontras, lat 27,1674S, long 49,5599W, NCCP Barbosa col., 23.v.2015, MZUSP 25038; TF Carrijo col., 23.v.2015, MZUSP 25580.

Notas de campo: em ninho de Cornitermes na beira da estrada; em ninho abandonado em barranco com Neocapritermes e Velocitermes; no solo; com formigas e nasutos em tronco

\subsubsection{Gênero 7}

(Tabs. 16; Figs. 186-191, 320)

Alado: Desconhecido.

Operário (Figs. 186-191): fontanela mediana, arredondada à elipsoide (Fig. 187); pósclípeo não inflado a moderadamente inflado (Fig. 186); mandíbula esquerda (Fig. 188) com o dente apical proeminente em relação à $\mathrm{M} 1+2$, M3 triangular com as margens laterais formando ângulo reto/agudo, processo molar não oculto pela proeminência molar; tíbia inflada; órgãos deiscentes conspícuos; tubo digestório sem segmento misto (Fig. 191, vista ventral); íleo terminando na lateral direita (Fig. 191, vista ventral); válvula entérica inerme (Figs. 189-190), com seis pregas simétricas oblongas, escamas subhexagonais, uniformes em toda a extensão da prega, com margens ornamentadas com espinhos pequenos; escamas interpregas mais largas que compridas, com margens ornamentadas com espinhos; assentamento da válvula entérica tubular, curto; cápsula cefálica com cobertura densa de cerdas longas em riste (Fig. 186); pronoto com cerdas longas concentradas na margem do lobo anterior e posterior (Fig. 186), meso e metanotos com cerdas longas na margem posterior; tergitos com cerdas concentradas no centro das placas voltadas para a região posterior, e esternitos com cerdas mais longas que as dos tergitos, concentradas no centro das placas; coloração da cápsula cefálica amarelada (Fig. 186); fontanela esbranquiçada (Fig 187).

Comparações: ver sob Hidrecotermes sp. 1. 


\section{Gên. 7 sp. 57}

(Tabs. 16; Figs. 186-191, 320)

Alado: Desconhecido.

Operário (Figs. 186-191): Como descrito para o gênero.

Material Examinado (Fig. 320): BRASIL. Rio Grande do Sul: São Francisco de Paula, lat 29,1437S, long 50,6226W, Pró-Mata, T. Schlemmermeyer col., 11.v.1995, MZUSP 11039, 11040, 11041, 11042, 11043, 11044; Cambará do Sul, lat 29,0531S, long 50,1008W, RG Santos col., 25.v.2015, MZUSP 25648.

Notas de campo: Em barranco na beira da estrada.

\subsubsection{Gênero 8}

(Tabs. 17, 18; Figs. 192-202, 327)

Alado (Figs. 192-193, 197): fontanela inconspícua em ambos os sexos (Fig. 193), região da fontanela deprimida; mancha mediana pouco conspícua; mandíbula esquerda (Fig. 197) com a ponta do dente apical na mesma altura que a de $M 1+2$, M3 triangular com as margens laterais formando ângulo obtuso, processo pré-molar não conspícuo, processo molar não oculto pela proeminência molar; pronoto subhexagonal (Fig. 193), margem anterior reta, sem incisão central, margens laterais bem retas, bem marcadas (pronoto mais anguloso); cápsula cefálica com cerdas longas em pequena quantidade (Fig. 192), esparsas e cobertura de pelos curtos; pronoto com poucas cerdas longas esparsas e pelos curtos; tergitos e esternitos com pelos curtos cobrindo as placas; coxa anterior com um conjunto de 4-5 cerdas longas em destaque; face interna da tíbia anterior com duas fileiras de 6-7 cerdas grossas; coloração da cápsula cefálica castanha-escura (Figs. 192-193), manchas frontais pouco mais claras que o restante da cápsula cefálica com margens pouco definidas; pilosidade da pleura alaranjada.

Operário (Figs. 194-196, 198-202): fontanela pequena, arredondada (Fig. 195); pósclípeo inflado (Fig. 194); mandíbula esquerda com o dente apical proeminente em relação à M1+2, M3 triangular com as margens laterais formando ângulo reto/agudo, 
processo molar não oculto pela proeminência molar; tíbia anterior inflada (Fig. 196); sem órgãos deiscentes conspícuos; tubo digestório sem segmento misto (Fig. 202); íleo com calibre uniforme em toda extensão, terminando na lateral direita (Fig. 202); válvula entérica inerme (Figs. 199-200), com seis pregas simétricas subovaladas, escamas mais largas que compridas na porção proximal da prega, estreitando-se ao longo da prega, com margens ornamentadas com espinhos (visíveis em aumento maior que 40X no microscópio, não visível nas imagens fornecidas); assentamento da válvula entérica tubular, curto (Fig. 202, lateral direita); cápsula cefálica com cobertura de cerdas medianas e longas (Fig. 194); pronoto com cerdas longas, concentradas na margem do lobo anterior e o lobo posterior (Fig. 194); tergitos e esternitos com cerdas no centro das placas; tergitos com cerdas longas, com cobertura densa, voltadas para a região posterior ou para cima; coxa anterior com um conjunto de 4-5 cerdas grossas; face interna do fêmur anterior com cerdas longas; face interna da tíbia anterior com duas fileiras de 6-7 cerdas grossas; coloração da cápsula cefálica esbranquiçada; fontanela esbranquiçada.

Comparações: ver comparações em Hydrecotermes (seção 4.4.20).

\section{Gên. 8 p. S3}

(Tabs. 17, 18; Figs. 192-202, 327)

Alado (Figs. 192-193, 197): Como descrito para o gênero.

Operário (Figs. 194-196, 198-202): Como descrito para o gênero.

Material Examinado (Fig. 327): BRASIL. Alagoas: Quebrangulo, lat 9,2288S, long 36,4259W, MP Silva col., 19.vi.2000, MZUSP 13712. Bahia: Conde, lat 11,7718S, long 37,7301W, JP Constantini col., 15.xi.2016, MZUSP 26648. Espírito Santo: Pedro Canário, lat 18,3557S, long 39,8445W, JP Constantini col., 20.xi.2016, MZUSP 26652; 21.xi.2016, MZUSP 26676(a), 26677. Paraíba: João Pessoa, lat 7,1480S, long 34,8614W, A Vasconcellos col., 01-20.vi.2000, MZUSP 13710, 13711. Pernambuco: Recife, Horto Dois Irmãos, lat 7,9999S, long 34,9473W, A Vasconcellos col., s/d, MZUSP 13702. 
Notas de campo: no solo; na base de árvore, solo muito escuro, superficialmente, estavam em pequenas estruturas com galerias, sempre muito amontoados.

\subsubsection{Gênero 9}

(Tabs. 17, 18; Figs. 203-214, 329)

Alado (Figs. 203-204, 208-209): margem dorsal da cápsula cefálica convexa em perfil (Fig. 203); fontanela pequena arredondada em ambos os sexos (Fig. 204); mancha mediana conspícua; mandíbula esquerda (Fig. 209) com o dente apical pouco proeminente em relação à M1+2, M3 triangular com as margens laterais formando ângulo obtuso, processo molar não oculto pela proeminência molar; pronoto subpentagonal (Fig. 204), margem anterior reta sem uma incisão central discreta, com incisão central na margem posterior; cápsula cefálica com cobertura de cerdas longas desordenadamente distribuídas, voltadas para a região anterior, e pelos curtos; pronoto com cerdas longas concentradas nas margens, meso e metanotos com cobertura de pelos curtos; tergitos e esternitos com cerdas concentradas no centro das placas; tergitos com cerdas curtas voltadas para a região posterior, e pelos; esternitos com cerdas mais longas que as dos tergitos; tíbias anteriores com cerdas grossas desorganizadas; coloração da cápsula cefálica castanha escura (Fig. 203-204), manchas frontais pouco mais claras que o restante da cápsula cefálica com margens pouco definidas; fontanela esbranquiçada (Fig. 204); pilosidade da pleura alaranjada (Fig. 208).

Operário (Figs. 205-207, 210-214): fontanela mediana, arredondada (Fig. 206); pósclípeo moderadamente inflado (Fig. 205); mandíbula esquerda (Fig. 210) com o dente apical com a ponta na mesma altura em relação à posição de M1+2, M3 triangular com as margens laterais formando ângulo reto/agudo, processo molar oculto pela proeminência molar; tíbia inflada; órgãos deiscentes conspícuos (Fig. 207), nos espécimes em álcool aparecem como corpos globulosos evaginados na região entre tórax e abdômen; tubo digestório com segmento misto presente (Fig. 212, vista ventral); lingueta mesentérica longa, não inflada; íleo terminando na lateral direita (Fig. 212, vista lateral direita); válvula entérica inerme (Figs. 213-214), com seis pregas simétricas subovaladas, com um espinho no centro da prega; escamas inconspícuas; assentamento da válvula entérica tubular, curto; cápsula cefálica densamente coberta por cerdas 
longas e medianas (Fig. 205); pronoto com cerdas longas concentradas na margem do lobo anterior (Fig. 205), meso e metanotos com cerdas na margem posterior; tergitos e esternitos com cerdas concentradas no centro das placas; tergitos com cerdas medianas voltadas para a região posterior ou para cima, e esternitos com cerdas medianas; coloração da cápsula cefálica esbranquiçada (Fig. 205); fontanela esbranquiçada (Fig. 206).

Comparações:

O enrolamento do tubo digestório do operário do Gênero 9 lembra o das espécies de Disjunctitermes que tem uma longa lingueta mesentérica não inflada. No entanto, em Gênero 9 o assentamento da válvula entérica é tubular, curto, enquanto que em Disjunctitermes é trilobado. Além disso, a margem da cápsula cefálica do operário em perfil no gênero Disjunctitermes é convexa, enquanto em Gênero 9 não é convexa. A mandíbula esquerda do alado do Gênero 9 não contém o processo pré-molar conspícuo enquanto em Disjuctitermes o processo é aparente. 0 operário de Gên. 9 também possui órgãos deiscentes conspícuos, ausentes em Disjunctitermes.

\section{Gên. 9 sp. V3}

(Tabs. 17, 18; Figs. 203-214, 329)

Alado (Figs. 203-204, 208-209): Como descrito para o gênero.

Operário (Figs. 205-207, 210-214): Como descrito para o gênero.

Material Examinado (Fig. 329): BRASIL. Rio de Janeiro: Santa Maria Madalena, lat 21,9522S, long 42,0148W, 24.xi.2016, MZUSP 26660; lat 21,8977S, long 41,9137W, JP Constantini col., 25.xi.2016, MZUSP 26647. Paraná: São João do Piraí, lat 25,8656S, long 48,9864W, TF Carrijo col., 22.v.2015, MZUSP 25601. Santa Catarina: Alfredo Wagner, lat 27,6706S, long 49,1559W, TF Carrijo col., 23.v.2015, MZUSP 25583; Lontras, lat 29,1836S, long 49,9994W, RG Santos col., 23.v.2015, MZUSP 25493(a); Praia Grande, lat 27,1675S, long 49,5599W, RG Santos col., 24.v.2015, MZUSP 25622. São Paulo: Ribeirão Grande, Parque Estadual de Intervales, lat 24,3085S, long 48,2735W, LCM Oliveira e EM Cancello col., 14.ix.1999, MZUSP 12465. 
Notas de campo: no solo; em madeira seca.

\subsubsection{Gênero 10}

(Tabs. 17, 18; Figs. 215-226, 334)

Alado (Fig. 219-221): duas manchas triangulares menores entre as manchas frontais e a fontanela (Fig. 220); fontanela maciça, arredondada, ligeiramente deprimida, ocupando 1/2 da cápsula cefálica em vista dorsal, tanto nas fêmeas quanto nos machos (Fig. 220); mandíbula esquerda (Fig. 221) com o dente apical muito mais proeminente em relação à M1+2, M3 triangular com as margens formando um ângulo agudo, processo pré-molar inconspícuo, processo molar não oculto pela proeminência molar; pronoto com margem anterior reta (Fig. 220, deformada pela montagem), margens laterais convexas, convergindo posteriormente; cápsula cefálica com uma densa cobertura de cerdas medianas e pelos curtos (Fig. 219); pronoto com cerdas concentradas ao longo das margens e pelos curtos (Fig. 219); tergitos e esternitos com cerdas curtas e pelos curtos concentrados no centro das placas; coxa anterior com 4-5 cerdas grossas (Fig. 219); fêmur anterior densamente coberto por cerdas longas; protíbia com duas fileiras com 10-12 cerdas grossas (Fig. 223), junto com o fêmur lembrando fracamente uma "perna raptorial”, coloração da cápsula cefálica castanha escura, manchas frontais e marcas triangulares levemente mais claras que o restante da cápsula cefálica, com margens pouco definidas; fontanela de mesma cor que o restante da cápsula cefálica (Fig. 220); pronoto levemente mais claro que o restante da cápsula cefálica (Fig. 220).

Operário (Figs. 215-218, 222-226): mono- ou dimórfico; fontanela com margens bem delineadas, deprimida no vertex, ocupando de $1 / 4$ a 3/4 da cápsula cefálica (Figs. 215, 217); pós-clípeo moderadamente a fortemente inflado $(216,218)$; mandíbula esquerda (Fig. 222) com o dente apical proeminente em relação à $M 1+2$, margem cortante entre M1+2 e a incisão, M3 triangular com as margens laterais formando um ângulo agudo; processo molar não oculto pela proeminência molar; profemur com a superfície ventral formando um sulco entre as duas fileiras de cerdas; protíbia com a face ventral fortemente achatada, lembrando (na associação com o fêmur) uma perna raptorial; sem órgãos deiscentes conspícuos; tubo digestório com segmento misto vestigial (Fig. 224, vista ventral); íleo terminando ventralmente (Fig. 224, vista ventral); válvula entérica 
inerme (Fig. 225-226), com seis pregas simétricas subovaladas; com escamas subpentagonais e 3-5 espinhos triangulares pequenos na região proximal das pregas; assentamento da válvula entérica tubular, curto (Fig. 224, vista ventral), cápsula cefálica com uma cobertura de cerdas de orientação e tamanho variável (Figs. 216-218); pronoto com cerdas longas principalmente concentradas na margem anterior do lobo anterior e nas laterais do lobo posterior, com orientação variável (Fig. 216, 218); tergitos e esternitos com cerdas curtas no centro das placas, com orientação variável; coxa anterior com 7-11 cerdas grossas; fêmur anterior com duas fileiras de cerdas menos organizadas que na protíbia; tíbia anterior com duas fileiras bem marcadas de cerdas espiniformes, na margem interna, variando de 6-16, cápsula cefálica amarela clara (Figs. 215-218); fontanela esbranquiçada (Figs. 215, 217).

Comparações: 0 Gênero 10 é facilmente reconhecido, pois possui a combinação de uma fontanela muito grande tanto no operário quanto no alado e cerdas espiniformes da tíbia anterior também de operários e alados.

\section{Gên. 10 sp. FonA}

(Tabs. 17, 18; Figs. 215-226, 334)

Alado (Fig. 219-221): Como descrito para o gênero.

Operário (Figs. 215-218, 222, 224-226): dimórfico; cerdas mais densas na cápsula cefálica e tergitos, de dois comprimentos, voltados para a porção posterior do corpo, uniformemente orientados. Operário 1 (Fig. 215) com fontanela ocupando 3/4 da cápsula cefálica em vista dorsal. Operário 2 (Fig. 214) com fontanela ocupando de $1 / 2$ a $1 / 4$ da cápsula cefálica em vista dorsal.

Material Examinado (Fig. 334): BRASIL. Bahia: Andaraí, lat 12,8072S, long 41,3313W, 13-14.xii.1990, EM Cancello e MT Ponte col., MZUSP 10367. Goiás: Caldas Novas, Parque Estadual da Serra de Caldas Novas, lat 17,7927S, long 48,7038W, 23.iii.2008, DE Oliveira col., UFG 1740, 1741. Minas Gerais: Poços de Caldas, Morro do Ferro (Norte), lat 21,9166S, long 46,5166W, 18.ix. 1967, RL Araujo col., MZUSP 0456. Rio de Janeiro. Santa Maria Madalena, Parque Estadual do Desengano, lat 21,9522S, long 42,0148W, 
24.xi.2016, JP Constantini col., MZUSP 26687. Rondônia: Porto Velho, Abunã, lat 9,5970S, long 65,3645W, 09.iii.2010, TF Carrijo e RG Santos col., MZUSP 13039; Jaci Paraná, lat 9,0245S, long 64,2530W, 16.ix.2010, TF Carrijo e RG Santos col., MZUSP 17193; lat 9,4502S, long 64,3674W, 12.i.2011, RG Santos e CY Mandai col., MZUSP 17196; lat 9,0293S, long 64,2499W, 07.i.2011, RG Santos e CY Mandai col., MZUSP 17197; lat 9,4526S, long 64,3900W, 20.i.2010, TF Carrijo e RG Santos col., MZUSP 17198; Nova Mutum Paraná, lat 9,2869S, long 64,7445W, 09.i.2011, RG Santos e CY Mandai col., MZUSP 17194, 17195; (mesma amostra do holótipo), 23.xii.1975, RL Araujo col., MZUSP 6480, (a); São Paulo: Ipiranga, 3.i.1909, Luederwaldt col., MZUSP 1199. COLOMBIA. Meta: San Juan Arana, cuchilla el tablazo vey(g)a, NW, Rio Güejar, vii.1992, LO Sánchez leg., MZUSP 24480. PARAGUAY. Cordillera: Vallenzuela, 04.i.1992, L Cabello e B Barrios col., MZUSP 10855.

Notas de campo: no solo; monte de terra no solo (ninho?); forrageando na serapilheira; em graveto.

\subsubsection{Gênero 11}

(Tab. 11; Figs. 227-236, 320, 321)

Alado: desconhecido.

Operário (Figs. 227-236): fontanela inconspícua a conspícua, envolta nas manchas cerebrais (Figs. 228, 233); pós-clípeo não inflado (Figs. 227, 232); mandíbula esquerda (Figs. 229, 235) com a ponta do dente apical na mesma altura que a de $M 1+2$, M3 triangular com as margens assimétricas; região entre M3 e processo molar formando uma margem reta; processo molar oculto ou não pela proeminência molar; órgãos deiscentes conspícuos ou não; tíbia não inflada (Fig. 227, 232, 234); tubo digestório (como em Aparatermes silvestrii, Fig. 107) com segmento misto vestigial; terminando na lateral direita; válvula entérica inerme (Fig. 230-231, 236) com seis pregas ovaladas, simétricas com disposição das escamas centrais variável, em geral com um espinho pequeno na margem das escamas centrais ou um espinho único grande no centro da prega; assentamento da válvula trilobado; cápsula cefálica com cerdas medianas e longas (Fig. 227, 232), esparsas; pronoto com cerdas longas concentradas na margem do 
lobo anterior e posterior (Fig. 232); tergitos e esternitos com cerdas curtas no centro das placas; fêmur com várias cerdas longas (Fig. 234); tíbias anteriores com duas fileiras de cerdas grossas (Fig. 234), densamente cobertas por cerdas de diferentes comprimentos; coloração da cápsula cefálica amarelada-alaranjada (Figs. 227-228, 232); fontanela esbranquiçada (Fig. 228, 233).

Comparações:

Os operários das espécies Aparatermes abbreviatus, Aparatermes cingulatus, Aparatermes silvestrii, Gên. 1 sp. ES2, Gên. 1 sp. S5, Gên. 11 sp. ES3, Gên. 11 sp. V2 são parecidos por ter M3 triangular com uma porção central proeminente e margens assimétricas, assentamento da válvula entérica trilobado, e um padrão de válvula entérica semelhante, sem porção armada.

Os operários das espécies A. abbreviatus e A. cingulatus são maiores, não possuem segmento misto e o íleo se estende até a região dorsal, estando o assentamento da válvula entérica escondido sob o colo.

Os operários de $A$. silvetrii, Gên. 11 sp. ES3 e Gên. 11 sp. V2 têm um tamanho intermediário entre as espécies comparadas aqui, têm segmento misto vestigial, o íleo termina na lateral direita do animal e possuem duas fileiras de cerdas grossas na tíbia anterior. É preciso confirmar a existência de órgãos deiscentes nos espécimes vivos dessas três espécies, pois esta característica (visível nos operários de Gên. 11 sp. V2) pode ser afetada pela conservação em álcool.

Os operários de Gên. 1 sp. ES2 e Gên. 1 sp. S5 são menores, não possuem segmento misto e o íleo se estende até a região dorsal, estando o assentamento da válvula entérica escondido sob o colo. Os órgãos deiscentes são visíveis nos espécimes conservados em álcool nas duas espécies.

Em relação aos alados conhecidos nas espécies comparadas aqui, a fontanela do alado de $A$. silvestrii é grande, circular e proeminente, única entre os alados conhecidos das espécies neotropicais. A fontanela dos alados de A. cingulatus e A. abbreviatus é pequena, arredondada, mais ou menos conspícua.

Com base no exposto acima, a espécie Aparatermes silvestrii deve ser transferida para um novo gênero, junto com as espécies Gên. 11 sp. ES3 E Gên. 11 sp. V2. Para maior embasamento dessa hipótese de agrupamento é importante conseguir amostras com a casta do alado para as duas espécies de Gên. 11. 


\section{Gênero 11 sp. ES3}

(Tab. 11; Figs. 227-231, 320)

Operário (Figs. 227-231): fontanela mediana, arredondada (Fig. 228); mandíbula esquerda com processo molar não oculto pela proeminência molar (Fig. 229); sem órgãos deiscentes conspícuos; válvula entérica inerme (Fig. 230-231), com seis pregas simétricas subovaladas, porção central das pregas com escamas pequenas com ápices pontiagudos voltados para o íleo, margens lisas, e escamas maiores ao redor, de mesmo formato. Demais caracerísticas como descrito para o gênero.

Material examinado (Fig. 320). BRASIL. Alagoas: Quebrangulo, lat 9,2288S, long 36,4259W, A Vasconcellos col., 20.vi.2000, MZUSP 13773; MP Silva col., 20.vi.2000, MZUSP 13774. Paraíba: João Pessoa, Mata do Buraquinho, lat 7,1480S, long 34,8614W, A Vasconcellos col., 01-20.vi.2000, MZUSP 11317. Pernambuco: Recife, Horto Dois Irmãos, lat 7,9999S, long 34,9473W, 04-08.vii.2000, MZUSP 13771.

Notas de campo: na serapilheira; no solo.

\section{Gên. 11 sp. V2}

(Tab. 11; Figs. 232-236, 321)

Operário (Figs. 232-236): fontanela pequena, arredondada a elipsoide (Fig. 233); mandíbula esquerda com processo molar oculto pela proeminência molar (Fig. 235); órgãos deiscentes conspícuos; fêmur com face ventral reta (Fig. 234); tíbia não inflada (Fig. 234); válvula entérica inerme (Fig. 236), com seis pregas simétricas subovaladas, com ornamentação das pregas assiméticas; três das pregas com as escamas subpoligonais na porção central, pequenas, com ápices pontiagudos e esclerotizados voltados para a pança, escamas maiores ao redor, de mesmo formato; as outras três pregas com um espinho grande na porção central. Demais características como descrito para o gênero.

Material Examinado (Fig. 321): BRASIL. Pernambuco: Recife, Horto Dois Irmãos, lat 7,9999S, long 34,9473W, MP Silva col.,04-08.vii.2000, MZUSP 11750. 
Comparações:

A pilosidade na cápsula cefálica é menos densa em Gên. 11 sp. ES3 em comparação à Aparatermes silvestrii e Gên. 11 sp. V2. Na espécie Gên. 11 sp. ES3 o processo molar da mandíbula esquerda não está oculto pela proeminência molar, o oposto do que ocorre nas outras duas espécies. A espécie Gên. 11 sp. V2 tem na região toraco-abdominal uma massa branca glandular aparente, além de ter uma válvula entérica que possui ornamentação mista, na região central da prega com três das pregas com um espinho único central e as outras três com escamas de margem esclerotizada, características que diferem esta espécie das duas outras.

\subsubsection{Gênero 12}

(Tabs. 21; Figs. 237-242, 323)

Alado: Desconhecido.

Operário (Figs. 237-242): fontanela mediana, arredondada; pós-clípeo inflado (Fig. 237); mandíbula esquerda (Fig. 238) com ponta do dente apical na mesma altura que a de M1+2, M3 triangular com as margens laterais formando ângulo reto/agudo, processo molar não oculto pela proeminência molar; sem órgãos deiscentes conspícuos; tíbia inflada, tubo digestório sem segmento misto (Fig. 242, vista ventral); íleo terminando ventralmente (Fig. 242, vista ventral), válvula entérica armada, com seis pregas simétricas subovaladas, com escamas subpoligonais e um espinho central, escamas de margens lisas; porção armada com seis placas, três maiores e três menores, ovaladas, que se enrolam da região interna do tubo para a região externa no assentamento da válvula entérica, ricamente ornamentadas com espinhos; assentamento da válvula entérica trilobado; cápsula cefálica (Fig. 237) com cobertura esparsa de cerdas longas e medianas; pronoto com cerdas longas concentradas na margem do lobo anterior e posterior; tergitos e esternitos com cerdas curtas no centro das placas, nos tergitos voltadas para a região posterior e nos esternitos; coloração da cápsula cefálica amarelada (Fig. 237); fontanela esbranquiçada.

Comparações: Ver comparações sob Patawatermes. 


\section{Gên. 12 sp. P1C}

(Tabs. 21; Figs. 237-242, 323)

Operário (Figs. 237-242): Como descrito para o gênero.

Material Examinado (Fig. 323): BRASIL. Espírito Santo: Afonso Cláudio, lat 20,2406S, long, 41,1825W, TF Carrijo col., 28.xi.2014, MZUSP 25142; Santa Tereza, lat 19,9484S, long 40,5080W, 27.xi.2014, TF Carrijo col., MZUSP 25143.

Notas de campo: No solo (MZUSP 25142, 25143).

\subsubsection{Gênero 13}

(Tabs. 16; Figs. 243-248, 322)

Alado: Desconhecido.

Operário (Figs. 243-248): fontanela mediana, arredondada a elipsoide (Fig. 244); pósclípeo fortemente inflado (Fig. 243); mandíbula esquerda (Fig. 245) com o dente apical muito proeminente em relação à $\mathrm{M} 1+2, \mathrm{M} 1+2$ com margem cortante curta, M3 triangular com as margens laterais formando ângulo reto/agudo, processo molar oculto proeminência molar; sem órgãos deiscentes conspícuos, porém todos os espécimes na amostra estavam eviscerados, tíbia inflada (Fig. 245), tubo digestório com segmento misto vestigial (Fig. 247, vista ventral); íleo terminando na lateral direita (Fig. 247, vista lateral direita); válvula entérica inerme, (Figs. 246, 248) com seis pregas simétricas oblongas, escamas subhexagonais, com margens ornamentadas com espinhos, uniformes em toda a extensão da prega, escamas interpregas mais largas que compridas com margens ornamentadas com espinhos; assentamento da válvula entérica tubular, curto; cápsula cefálica com cobertura densa de cerdas longas em riste (Fig. 243); pronoto com cerdas longas concentradas na margem do lobo anterior e posterior, meso e metanotos com cerdas na margem posterior, em grande quantidade (Fig. 243); cerdas dos notos mais longas e destacadas que as dos demais tergitos; tergitos com cerdas concentradas no centro das placas voltadas para a região posterior ou para cima, e esternitos com cerdas mais longas que as dos tergitos; coloração da cápsula cefálica esbranquiçada (Fig. 243); fontanela esbranquiçada (Fig 244). 
Comparações: ver comparações sob Hydrecotermes.

\section{Gên. 13 sp. $S 6$}

(Tabs. 16; Figs. 243-248, 322)

Operário (Figs. 243-248): Como descrito para o gênero.

Material Examinado (Fig. 322): BRASIL. Espírito Santo: Sooretama, Reserva Biológica de Sooretama, lat 19,0123S, long 40,1030W, RG Santos col., 26.xi.2014, MZUSP 24570.

Notas de campo: No solo ao redor de madeira apodrecida.

\subsubsection{Grigiotermes Mathews 1977}

(Tab. 21; Figs. 249-258, 324)

Espécie tipo: Grigiotermes metoecus Mathews, 1977 por designação original.

Alado (Fig. 249): Como em Bourguignon et al. 2016a.

Operário (Figs. 250-258): fontanela de comprimento mediano, arredondada; pós-clípeo inflado (Figs. 250-252); mandíbula esquerda (Figs. 251, 253) com o dente apical proeminente em relação à M1+2, M3 triangular com margens laterais formando ângulo reto/agudo, processo molar oculto pela proeminência molar (ver comentários); sem órgãos deiscentes conspícuos, tíbia inflada, tubo digestório (Fig. 258) sem segmento misto; porção final do mesêntero pode estar ligeiramente inflada em alguns espécimes; íleo terminando na lateral direita (Fig. 258, vista lateral direita); válvula entérica armada (Figs. 254-257), com seis pregas simétricas variáveis, com escamas subpoligonais com disposição variável, escamas de margens variáveis; porção armada com seis placas simétricas, de formato variável, ricamente ornamentadas com espinhos; assentamento da válvula entérica tubular, curto (Figs. 258); cápsula cefálica com cobertura densa ou esparsa de cerdas medianas e longas (Figs. 250, 252); pronoto com cerdas longas concentradas na margem do lobo anterior e posterior; tergitos e esternitos com cerdas curtas no centro das placas; coxas e tíbias densamente cobertas por cerdas de diferentes comprimentos, coloração da cápsula cefálica amarelada (Figs. 250, 252); fontanela esbranquiçada. 
Comentários: Ver comparações sob Patawatermes. Mathews (1977) descreve o processo molar em Grigiotermes meteocus não oculto pela proeminência molar. Nas duas amostras de Grigiotermes hageni (sinônimo sênior de G. meteocus) que foram analisadas neste trabalho o processo molar estava oculto ou semi-oculto pela proeminência molar, o que indica esta característica varia na espécie.

Grigiotermes hageni (Snyder e Emerson, 1949): 105

(Tab. 21; Figs. 249-251, 254-255, 324)

Anoplotermes hageni Snyder e Emerson em Snyder, 1949

Grigiotermes metoecus Mathews, 1977: 96-98, sinônimo júnior.

Tipos: alado, operário (AMNH) não examinado; alado, operário (IEA), não examinado. Localidade tipo: ARGENTINA. Bebitez, Colonia. BRASIL. Mato Grosso do Sul: Urucum (Corumbá); Mato Grosso: Coxipó (Cuiabá).

Alado (Fig. 249): Como em Bourguignon et al. 2016a.

Operário (Figs. 250-251, 254-255): válvula entérica armada (Figs. 254-255), com seis pregas simétricas oblongas, com escamas subpoligonais, com disposição uniforme ao longo das pregas, escamas com a margem distal ricamente ornamentada com espinhos; porção armada com seis placas simétricas, subquadrangulares, ricamente ornamentadas com espinhos longos; cápsula cefálica com pilosidade densa (Fig. 250). Demais características como descrito para o gênero.

Material examinado (Fig. 324): BRASIL. Pernambuco: Recife, Horto Dois Irmãos, lat 7,9999S, long 34,9473W , A Vasconcellos col., 04-08.vii.2000, MZUSP 11318, 13503.

\section{Grigiotermes sp. 1}

(Tab. 21; Figs. 252-253, 256-257, 324)

Alado: Desconhecido. 
Operário (Figs. 252-253, 256-257): válvula entérica armada (Figs. 256-257), com seis pregas simétricas subovaladas, com escamas subpoligonais, e um espinho no centro da prega, escamas com a margem distal lisas ou com 1-3 espinhos curtos; porção armada com seis placas simétricas, longas, que desenrolam da parte interna do tubo para a parte externa, no assentamento da válvula entérica, ornamentadas com espinhos principalmente concentrados nas margens da placa; cápsula cefálica com pilosidade esparsa (Fig. 252). Demais como descrito para o gênero.

Material examinado (Fig. 324): BRASIL. Espírito Santo: Sooretama, Reserva Biológica de Sooretama, lat 19,0123S, long 40,1030W, RG Santos col., 26.ii.2014, MZUSP 24569. São Paulo: Salesópolis, Estação Biológica de Boraceia, lat 23,6308S, long 45,8697W, PIC Machado col., 08.ii.2016, MZUSP 25812. Paraná: Tijucas do Sul, lat 25,8494S, long 49,0406W, RG Santos col., 22.v.2015, MZUSP 25651.

Notas de campo: no solo.

Comparações: as duas espécies tem um padrão de enrolamento do tubo digestório semelhante, e apresentam uma válvula entérica armada com seis placas ornamentadas com espinhos. Em Grigiotermes hageni a pilosidade na cápsula cefálica é mais densa que em Grigiotermes sp. 1. Em relação à válvula entérica, as placas armadas são subquadrangulares em Grigiotermes hageni e subretangulares em Grigiotermes sp. 1, nesta última essas estruturas estão enroladas (Fig. 256); entre as duas espécies as escamas nas pregas apresentam diferenças de ornamentação (Figs. 255, 257).

4.4.19. Humutermes Bourguignon e Roisin em Bourguignon et al., 2016a (Tabs. 8, 9; Figs. 259-265, 323)

Alado (Figs. 259-260): Como descrito para o gênero Anoplotermes (ver a seção 'comparações' abaixo).

Operário (Figs. 261-265): Como descrito para o gênero Anoplotermes (ver a seção 'comparações' abaixo). 
Comparações:

Os gêneros Humutermes e Longustitermes são os gêneros mais parecidos morfologicamente com Anoplotermes levando em consideração a presença da lingueta mesentérica fortemente dilatada e a cápsula cefálica com a margem dorsal convexa e com cobertura densa de cerdas. É possível que Humutermes seja sinonimizado com Anoplotermes no futuro, pois a única diferença entre as espécies dos dois gêneros é a válvula entérica.

O operário de Longustitermes manni possui um corpo alongado e um assentamento da válvula entérica trilobado, diferente do que ocorre em Anoplotermes. Além disso, a lingueta mesentérica é muito mais curta em Longustitermes quando comparada com Anoplotermes.

O operário de Disjunctitermes possui padrão de pilosidade e forma da cabeça parecidos com os do operário de Anoplotermes, no entanto a lingueta mesentérica não apresenta dilatação, o assentamento da válvula entérica é trilobado, e as mandíbulas de alados e operários nos dois gêneros apresentam diferenças nos processos pré-molar e molar.

Humutermes krishnai Bourguignon e Roisin em Bourguignon et al., 2016a

(Tabs. 8, 9; Figs. 259-265, 323)

Tipos: operário (RIB)

Localidade tipo: GUIANA FRANCESA. Nouragues Inselberg station.

Alado (Figs. 259-260): fontanela elipsoide esbranquiçada (Fig. 260); mancha mediana elipsoide; pronoto subquadrangular (Fig. 260); margens arredondadas. Demais características como o descrito para o gênero Anoplotermes.

Operário (Figs. 261-265): válvula entérica armada (Figs. 264-265), com seis pregas simétricas, com uma porção proximal bojuda e uma porção distal alongada, escamas arredondadas de margens lisas na porção bojuda, escamas maiores, subpoligonais, com margens ornamentadas lisas, na porção alongada das pregas; escamas da região interpregas subpoligonais, com margens ornamentadas com espinhos; porção armada 
com seis placas assimétricas esclerotizadas arredondadas, com as margens ornamentadas de espinhos longos.

Material Examinado (Figs. 323): BRASIL. Alagoas: Quebrangulo, lat 9,2288S, long 36,4259W, A Vasconcellos col.,19.vi.2000, MZUSP 13699; MP Silva col., 19.vi.2000, MZUSP 13695. Bahia: Conde, lat 11,7718S, long 37,7301W, JP Constantini col., 15.xi.2016, MZUSP 27356; Ilhéus, Mata da Esperança, lat 14,8039S, long 39,0455W, C Bordereau col., 15.xi.2000, MZUSP12003; YT Reis col., 14.xi.2000, MZUSP 12001; 15.xi.2000, MZUSP 12002; Mata de São João, Reserva Ecológica de Sapiranga, lat 12,5850S, long 38,0457W, EM Cancello e YT Reis col., vii.2001, MZUSP 12000; 27.vii.2001, MZUSP 11997 Paraíba: João Pessoa, Mata do Buraquinho, lat 7,1480S, long 34,8614W, A Vasconcellos col., 01-20.vi.2000, MZUSP 12710, 12712, 12713. Sergipe: Santa Luzia do Itanhy, Mata do Crasto, lat 11,3633S, long 37,4155W, YT Reis e EM Cancello col., 29.vii.2001, MZUSP 11993, 11995.

Notas de campo: no solo.

4.4.20. Hydrecotermes Bourguignon e Roisin em Bourguignon et al. 2016a: 23 (Tabs. 19; Figs. 266-274, 331)

Espécie tipo: Hydrecotermes arienesho Bourguignon e Roisin em Bourguignon et al., 2016a por designação original.

Alado (Figs. 266-267, 270): cápsula cefálica convexa em perfil (Fig. 266); fontanela pequena arredondada nos dois sexos (Fig. 267); mancha mediana inconspícua; margem do pós-clípeo com cápsula cefálica côncava (Fig. 267); mandíbula esquerda (Fig. 270) com dente apical mais curto em relação a ponta de M1+2, M3 triangular, processo prémolar visível, muito próximo da margem do M3, processo molar não oculto pela proeminência molar; pronoto em forma de semicircunferência, margem anterior com uma incisão central discreta, com emarginados, sem incisão da margem posterior; cápsula cefálica com poucas cerdas longas e médias (Fig. 266), coberta por pelos curtos; pronoto com cerdas longas e médias nas margens anterior e posterior (Fig. 266) e pelos curtos em toda a placa; tergitos e esternitos com cerdas curtas e pelos curtos cobrindo o 
centro das placas voltadas posteriormente; face interna das tíbias com cerdas grossas, dispostas desorganizadamente; coloração da cápsula cefálica castanha escura (Figs. 266267), manchas frontais pouco mais claras que o restante da cápsula cefálica com margens pouco definidas; fontanela branca; pronoto pouco mais claro que a cápsula cefálica.

Operário (Figs. 268-269, 271-274): cápsula cefálica convexa em perfil (Fig. 268); fontanela pequena, arredondada, envolta nas manchas cerebrais (Fig. 269); pós-clípeo inflado (Fig. 268); mandíbula esquerda (Fig. 271) com o dente apical proeminente em relação à M1+2, M3 triangular com as margens laterais formando ângulo reto/agudo, processo molar oculto pela proeminência molar; sem órgãos deiscentes conspícuos; tíbia inflada; tubo digestório sem segmento misto (Fig. 274, vista ventral); íleo terminando na lateral direita (Fig. 274, vista lateral direita); válvula entérica inerme (Fig. 272-273), com seis pregas simétricas oblongas, escamas subhexagonais, com margens ornamentadas com espinhos, uniformes em toda a extensão da prega, escamas interpregas mais largas que compridas com margens ornamentadas com espinhos; assentamento da válvula entérica tubular, curto; cápsula cefálica com cobertura densa de cerdas medianas e longas (Fig. 268); pronoto com cerdas longas concentradas na margem do lobo anterior e posterior; meso- e metanotos com cerdas longas concentradas na margem posterior; tergitos com cerdas curtas no centro das placas voltadas posteriormente, esternitos com cerdas medianas; coxas e tíbias densamente cobertas por cerdas medianas; coloração da cápsula cefálica esbranquiçada (Figs. 268269); fontanela esbranquiçada (Fig. 269).

\section{Comparações:}

Os operários de Gênero 4, Gênero 7, Gênero 8, Gênero 13 e Hydrecotermes são parecidos entre si com base no enrolamento do tubo digestório. 0 Gênero 7 possui órgãos deiscentes conspícuos, ausentes nos outros quatro gêneros. 0 operário do Gênero 8 apresenta cerdas grossas na tíbia anterior ausentes nos outros quatro gêneros. O operário de Gênero 4 apresenta cerdas grossas nas coxas anteriores, ausente nos operários dos outros quatro gêneros, e padrão diferente de válvula entérica. Todos os espécimes na amostra do Gênero 13 estavam eviscerados. 0 processo pré-molar da mandíbula esquerda está oculto no operário do Gênero 13 e não oculto em 
Hydrecotermes. 0 íleo termina ventralmente em Hydrecotermes e na lateral direita do Gênero 13. Em Gênero 13 o assentamento da válvula entérica é longo e em e Hydrecotermes bem curto.

\section{Hydrecotermes sp. 1}

(Tabs. 19; Figs. 266-274, 331)

Alado (Figs. 266-267, 270): como descrito para o gênero.

Operário (Figs. 268-269, 271-274): como descrito para o gênero.

Material Examinado (Fig. 331): BRASIL. Alagoas: Quebrangulo, lat 9,2288S, long 36,4259W , WO Almeida col., 19.vi.2000, MZUSP 13507. Bahia: Ilhéus, lat 14,8039S, long 39,0455W, Ceplac, Mata Zoobotânica, YT Reis col., 18.i.2001, MZUSP 11635; Porto Seguro, ESPAB, lat 16,3831S, long 39,1666W, YT Reis col., 22.i.2003, MZUSP 12490. Espírito Santo: Afonso Cláudio, lat 20,2406S, long 41,1825W, RG Santos col., 28.xi.2014, MZUSP 24571(a); TF Carrijo col., 28.xi.2014, MZUSP 24571(a); Pedro Canário, lat 18,3557S, long 39,8445W, JP Constantini col., 21.xi.2016, MZUSP 26631(a); NCCP Barbosa col., 21.xi.2016, MZUSP 26646; Santa Bárbara, lat 20,0104S, long 43,4696W, TF Carrijo col., 21.xi.2014, MZUSP 24566; Santa Teresa, lat 19,9078S, long 40,5414W, NCCP Barbosa col., 22.xi.2016, MZUSP26635, 26640; RG Santos col., 27.xi.2014, MZUSP24558; JP Constantini col., 22.xi.2016, MZUSP 26669, 26671, 26674; Sooretama, lat 19,0505S, long 40,0662W, RG Santos col., 25.xi.2014, MZUSP 24563; NCCP Barbosa col., 26.xi.2014, MZUSP 24560; TF Carrijo col., 24.xi.2014, MZUSP 24574; 25.xi.2014, MZUSP 24556; 26.xi.2014, MZUSP 26909; 27.xi.2014, MZUSP 25876; RG Santos col., 26.xi.2014, MZUSP 24564, 25510. Paraíba: João Pessoa, Mata Buraquinho, lat 7,1480S, long 34,8614W, A Vasconcellos col., 01-20.vi.2000, MZUSP 13493, 13498, 13500, 13501. Paraná: São João do Piraí, lat 25,8655S, long 48,9863W, NCCP Barbosa col., 22.v.2015, MZUSP 25552; TF Carrijo col., 22.v.2015, MZUSP 25626, 25627, 25672; Tijucas do Sul, lat 25,8493S, long 49,0406W, NCCP Barbosa col., 22.v.2015, MZUSP 25590. Pernambuco: Serra das Russas, lat 8,1196S, long 34,9641W, RL Araujo col., 13.vii.1974, MZUSP 5474. São Paulo: São Paulo, lat 23,5503S, long 46,6339W, RL Araujo e C Leite col., 26.x.1944, MZUSP 2556; Cidade Universitária, EM Cancello col., 20.ix.1978, MZUSP 15576; Ipiranga, F Silvestri col., 1927, MZUSP 26151; Itanhaém, lat 24,1993S, long 46,8705W, LR Fontes, AG 
Bandeira e PS Terra col., 22.ii.1979, MZUSP 7795; LR Fontes e PS Terra col., 26.iii.1979, MZUSP 7828; LR Fontes e AS Marques col., 29.vii-03.viii.1978, MZUSP 7711, 7712, 7713; Rio Silveira, lat 23,7296S, long 45,8148W, T Schelemmermeyer col., 29.iv.1998, MZUSP 10977; 30.iv.1998, MZUSP 10975; Salesópolis, Estação Biológica de Boraceia, lat 23,6308S, long 45,8697W, Brandão, Ejchel, Johnson e Kovarick col., 17-18.xii.1992, MZUSP 10563; CRF Brandão col., 14.ix.1978, MZUSP 11101; EM Cancello col., 30.ix.1989, MZUSP 9197; T Schelemmermeyer col., ix.1995, MZUSP 10554, 10558; v.1996, MZUSP 10718; vii.1996, MZUSP 10557; 22.iv.1997, MZUSP 10656; 23.iv.1997, MZUSP 10570; i.1998, MZUSP 10562; 08.i.1998, MZUSP 11016; 10-20.ii.1998, 15294(a); 08.x.1998, MZUSP 10966, 10967, 10968; 30.ix.1998, MZUSP 10974; s/d, 10552, 10553, 10555, 10556, 10559, 10560, 10567, 10568, 10569, 10571, 10572, 10574, 10575, 10578, 10579, 10964; EM Cancello, LCM Oliveira e T Schelemmermeyer col., 07.x.1998, MZUSP 10964; 10580; 08.x.1998, MZUSP 10969; PIC Machado col., 08.ii.2016, MZUSP 26152(a), 26153; Ribeirão Grande, Parque Estadual de Intervales, lat 24,3085S, long 48,2735W, EM Cancello e LCM Oliveira col., 16.ix.1999, MZUSP 12464. Rio de Janeiro: Mendes, lat 22,5249S, long 43,7312W, RL Araujo col., 20.i.1974, MZUSP 5275; Santa Maria Madalena, lat 21,9522S, long 42,0148W, JP Constantini col., 24.xi.2016, MZUSP 26662, 26665; lat 21,8977S, long 41,9137W, JP Constantini col., 25.xi.2016, MZUSP 26634, 26636(a), 26641, 26645, 26661, 26664; LCM Oliveira col., 02.x.2001, MZUSP 12485, 12486, 13506; 05.x.2001, MZUSP 12484; 06.x.2001, MZUSP 12487. Rio Grande do Sul: São Leopoldo, lat 29,7625S, long 51,1330W, RG Santos col., 26.v.2015, MZUSP 25644(a); TF Carrijo col., 26.v.2015, MZ 25497. Santa Catarina: Blumenau-Curitibanos, lat 26,8849S, long 49,0863W, RL Araujo col., 29.xii.1975, MZUSP 6470; Cunha Porã, lat 26,8565S, long 53,1673W, RG Santos col., 29.v.2015, MZUSP 25586; Lontras, lat 27,1675S, long 49,5599W, RG Santos col., 23.v.2015, MZUSP 24573; Praia Grande, lat 29,1836S, long 49,9994W, TF Carrijo col., 24.v.2015, MZUSP 25655; São Miguel do Oeste, lat 26,7286S, long 53,5203W, 27.xii.1975, RL Araujo col., MZUSP 6474.

Notas de campo: no solo, em raiz de gramínea; em raiz de arbusto, ninho abandonado no solo, na serapilheira; ninho epígeo fofo; dentro de toco podre fincado, ocupava com Gênero 2 sp. MCH resto de palmeira que continha algum solo fofo e de cor escura. 
Comparações: As espécies de Hydrecotermes são separadas pelo tamanho e pilosidade. Os operários de Hydrecotermes sp. 1 são maiores, seguido por Hydrecotermes arienesho e Hydrecotermes kawaii respectivamente. A pilosidade da cápsula cefálica é mais densa em Hydrecotermes sp. 1, seguida por H. kawaii e H. arienesho, respectivamente. Bourguignon et al. (2016) indica uma diferença no tamanho dos olhos dos alados entre $H$. kawaii e $H$. arienesho, porém não foram analisados alados dessas duas espécies neste trabalho.

4.4.21. Longustitermes Bourguignon e Roisin em Bourguignon et al. 2010: 364-367 (Tabs. 19, 20; Figs. 275-280, 329)

Espécie Tipo: Anoplotermes manni Snyder 1922, por designação original.

Alado e operário como em Bourguignon et al., 2010

Longustitermes manni (Snyder): 29

(Tabs. 19, 20; Figs. 275-280, 329)

Anoplotermes manni Snyder 1922

Anoplotermes linearis Snyder 1926: 53, sinônimo júnior

Tipos: operário (USNM), não examinado.

Localidade tipo: HONDURAS. Lombardia.

Alado: Como em Bourguignon et al., 2010.

Operário (Figs. 275-280): segmento misto presente (como o tubo digestório de Anoplotermes meridianus, Fig. 44), com lingueta mesentérica curta, inflada; íleo terminando na lateral direita; porção final do mesêntero inflada, globulosa; assentamento da válvula trilobado. Demais características como Bourguignon et al., 2010.

Material Examinado (Fig. 329): BRASIL. Alagoas: Quebrangulo, lat 9,2288S, long 36,4259W, MP Silva col., 19.vi.2000, MZUSP 13713; 20.vi.2000, MZUSP 13714; A Vasconcellos col., 21.vi.2000, MZUSP 13894. Bahia: Mata de São João, Reserva Ecológica de Sapiranga, lat 12,5677S, long 38,0367W, YT Reis e EM Cancello col., 26.vii.2001, 
MZUSP 12496; Porto Seguro, lat 16,4705S, long 39,2384W, JP Constantini col., 17.xi.2016, MZUSP 26655.

Notas de campo: no solo; no solo com Ruptitermes reconditus.

4.4.22. Patawatermes Bourguignon e Roisin em Bourguignon et al. 2016a: 25

(Tabs. 21, 23; Figs. 281-294, 325)

Alado (Figs. 285-287, 289: Como descrito em Bourguignon et al. 2016a.

Operário (Figs. 281-284, 290-294): pós-clípeo inflado (Figs. 281, 288); mandíbula esquerda (Figs. 282, 290) com o dente apical proeminente em relação à M1+2, M3 triangular com as margens laterais formando ângulo reto/agudo, processo molar não oculto pela proeminência molar; tubo digestório com segmento misto presente (Fig. 294, vista ventral), com lingueta mesentérica curta inflada (Fig. 294, vista ventral); íleo terminando na lateral direita (Fig. 294, vista lateral direita); válvula entérica armada (Fig. 283-284, 291-292), com seis pregas simétricas oblongas, com escamas subpoligonais, com disposição uniforme ao longo das pregas, escamas com as margens; porção armada com seis placas simétricas, ricamente ornamentadas com espinhos longos; assentamento da válvula entérica tubular, curto (Fig. 294, vista lateral direita). Demais características como descrito em Bourguignon et al. 2016.

Comparações:

Os operários de Echinotermes, Gênero 12, Grigiotermes, Humutermes e Patawatermes tem válvula entérica armada com seis placas esclerotizadas. No entanto, o operário de Echinotermes e Gên. 12 possui assentamento da válvula entérica trilobado e o operário de Humutermes possui lingueta mesentérica longa e inflada. Os operários de Grigiotermes e Patawatermes são semelhantes entre si, com segmentos mistos ausentes e assentamentos da válvula entérica tubulares. Entre os alados de Patawatermes há dimorfismo sexual na forma da fontanela, característica que precisa ser confirmada para os alados de Grigiotermes. 
Patawatermes nigripunctatus (Emerson, 1925): 426-427

(Tab. 21; Figs. 281-284; 325)

Anoplotermes (Anoplotermes) nigripunctatus Emerson, 1925

Tipos: alado (AMNH) não examinado.

Localidade tipo: GUIANA. Cuyuni-Mazaruni: Bartica, Kartabo.

Alado: Como em Bourguignon et al. 2016a.

Operário (Figs. 281-284): válvula entérica armada (Figs. 283-284), com seis pregas simétricas oblongas, com escamas subpoligonais, com escamas lisas ou com 1-3 espinhos curtos, e porção central da prega evaginada; porção armada com seis placas simétricas, ricamente ornamentadas com espinhos longos.

Material Examinado (Fig. 325): BRASIL. Alagoas: Quebrangulo, lat 9,2288S, long 36,4259W , WO Almeida col., 21.vi.2000, MZUSP 13508. Paraíba: João Pessoa, Mata do Buraquinho, lat 7,1480S, long 34,8614W, A Vasconcellos col., 01-20.vi.2000, MZUSP 13494, 13495, 13496, 13497, 13499. Pernambuco: Recife, Horto Dois Irmãos, lat 7,9999S, long 34,9473W, 04-08.vii.2000, MZUSP 13502; A Vasconcellos, MP Silva col., 04-08.vii.2000, MZUSP 13504, 13505.

Notas de campo: no solo.

Patawatermes turricola (Silvestri, 1901) : 8

(Tabs. 21, 23; Figs. 285-294, 325)

Anoplotermes turricola Silvestri, 1901

Anoplotermes bequaerti Snyder e Emerson em Snyder 1949: 104, sinônimo júnior.

Tipos: alado, operário, ninfa (AMNH) não examinado; alado (IEA) não examinado, alado, operário (USNM) não examinado.

Localidade tipo: BRASIL. Mato Grosso: Cuiabá. 
Alado (Figs. 285-286): fontanela da fêmea alada subovalada grande (Fig. 285), macho alado com fontanela menos conspícua que na fêmea (Fig. 286); mandíbula esquerda (Fig. 289) com o dente apical proeminente em relação à M1+2, M3 triangular, processo prémolar conspícuo, processo molar não oculto pela proeminência molar; fontanela esbranquiçada na fêmea (Fig. 285) e pouco mais escuro que o restante da cápsula cefálica no macho (Fig. 286). Demais características como descrito em Bourguignon et al. 2016.

Operário (Figs. 288, 290-294): órgãos deiscentes conspícuos; alguns espécimes com o conteúdo evertido, sem romper o envoltório abdominal; válvula entérica armada (Figs. 291-293), com seis pregas simétricas oblongas, com escamas subpoligonais, com disposição uniforme ao longo das pregas, escamas com a margem distal ricamente ornamentada com espinhos; porção armada com seis placas simétricas, ricamente ornamentadas com espinhos longos.

Material Examinado (Fig. 325): BRASIL. Bahia: Ilhéus, lat 14,8039S, long 39,0455W, Mata Esperança, C Bordereau col., 21.xi.2000, MZUSP 22692. Espírito Santo: Pedro Canário, lat 18,3557S, long 39,8445W, JP Constantini col, 21.xi.2016, MZUSP 26670; Sooretama, lat 18,9897S, long 40,0380W, TF Carrijo col., 25.xi2014, MZUSP 24562; RG Santos col., 26.xi.2014, MZUSP 24567(a). São Paulo: Leme, lat 22,1867S, long 47,3943W, RL Araujo col., 13.xi.1944, MZUSP 2432; São Bernardo, lat 23,6791S, long 46,5590W, W Maluf col., 20.xi.1950, MZUSP 3286 (a); São Paulo, lat 23,5503S, long 46,6339W, RL Araujo col., 12.xii.1944, MZUSP 2702 (pq); 27.i.1948, MZUSP 3093 (pq); 3094 (a), 3096 (a); 24.x.1950, MZUSP 9886 (pq); 31.x.1950, MZUSP 13709; 01.i.1974, MZUSP 2996 (a); Morumbi, JF Fialo col., 29.v.1951, MZUSP 3354.

Notas de campo: na areia na base de árvore; no solo mais seco; em tronco podre com bastante terra.

Comparações: Os operários de Patawatermes nigripunctatus são menores que os de $P$. turricola. A válvula entérica nos dois operários se diferencia na disposição de espinhos nas placas e nas margens das escamas das pregas. 
4.4.23. Ruptitermes Mathews 1977: 98-100

(Tabs. 22, 23; Figs. 302-312, 333)

Espécie-tipo: Ruptitermes xanthochiton Mathews 1977, por designação original.

Alado (Fig. 302-303, 306): Como em Acioli e Constantino, 2015.

Operário (Fig. 304-305, 307-312): Como em Acioli e Constantino, 2015.

Comparações: Os operários do gênero Ruptitermes são facilmente identificados, pois seus representantes possuem cabeças esclerotizadas e escurecidas (exceto Ruptitermes bandeirai), tergitos escurecidos (exceto Ruptitermes bandeirai), além de órgãos deiscentes.

Ruptitermes bandeirai Acioli e Constantino, 2015

(Tab. 22; Fig. 299-301; 332)

Tipos: operário (MZUSP), examinado.

Localidade tipo: BRASIL. Alagoas: Quebrangulo, Pedra Talhada.

Alado: Como em Acioli e Constantino, 2015.

Operário (Figs. 299-301): válvula entérica armada (Fig. 301), com seis pregas assimétricas subovaladas, porção central da prega forma uma bolsa evaginada, com um espinho na ponta, escamas subhexagonais com margens lisas; três pregas com a região distal desenvolvida, com espinhos curtos. Demais características como em Gênero 5 (ver a seção "comparações" a seguir).

Material Examinado (Fig. 332): BRASIL. Alagoas: Quebrangulo, Pedra Talhada, lat 9,2288S, long 36,4259W, A Vasconcellos col., 21.vi.2000, MZUSP 11749. Bahia: Ilhéus, lat 14,8039S, long 39,0455W, Mata Esperança, YT Reis col., 21.vi.2001, MZUSP 13770.

Notas de campo: no solo (13770). 
Comparações:

0 operário de Ruptitermes bandeirai e de Gên. nov. 5 sp. V4 compartilham a presença de órgãos deiscentes na região toraco-abdominal, padrão de enrolamento do tubo digestório e de pilosidade da cápsula cefálica. A principal diferença entre os operários das duas espécies é o padrão de válvula entérica. No operário de Ruptitermes bandeirai três das pregas da válvula entérica possuem espinhos desenvolvidos na porção distal, enquanto que no operário de Gên. 5 sp. V4 os espinhos são muito menos desenvolvidos. A válvula entérica de Gên. $5 \mathrm{sp}$. V4 parece ser uma forma reduzida da válvula entérica de Ruptitermes bandeirai.

Os operários de Ruptitermes bandeirai e Tetimatermes oliveirae têm válvulas entéricas muito parecidas com três das pregas apresentando padrão semelhante de espinhos extrovertidos na luz da pança. As características que justificam a separação das duas espécies são a presença de órgão deiscentes em Ruptitermes bandeirai, ausente em Tetimatermes e a tíbia anterior em forma de colher presente em Tetimatermes e ausente em Ruptitermes bandeirai.

Ruptitermes pitan Acioli e Constantino, 2015

(Tabs. 21, 22; Figs. 302-309, 333)

Tipos: operário (DZUB), não examinado; operários, alados(MZUSP), examinados. Localidade tipo: BRASIL. Distrito Federal: Brasília, Fazenda Água Limpa.

Alado (Figs. 302-303, 306): mandíbula esquerda (Fig. 306) com a ponta do dente apical na mesma altura que a de M1+2, M3 reduzido, processo pré-molar conspícuo muito próximo da margem do M3, processo molar oculto pela proeminência molar. Demais características como em Acioli e Constantino, 2015.

Operário (Figs. 304-305, 307-309): Como em Acioli e Constantino, 2015.

Material Examinado (Fig. 333): BRASIL. São Paulo: São Paulo, lat 23,5503S, long 46,6339W, Anhembi, C Torres, 18.viii.1979, MZUSP 8867(a). 


\section{Ruptitermes reconditus (Silvestri, 1901)}

(Tabs. 22; Figs. 310-312, 333)

Speculitermes proratus Emerson em Snyder, 1949: 110, sinônimo júnior

Tipos: alado, operário (AMNH), não examinado; alado, operário (IEA), não examinado; alado, operário (MCG), não examinado.

Localidade tipo: BRASIL. Mato Grosso: Coxipó (Cuabá).

Alado: Como em Acioli e Constantino, 2015.

Operário (Figs. 310-312): Como em Acioli e Constantino, 2015.

Material Examinado (Fig. 333): BRASIL. Bahia: Conde, lat 11,7718S, long 37,7301W, JP Constantini col., 15.xi.2016, MZUSP 26657; Ilhéus, lat 14,8039S, long 39,0455W , Mata da Esperança, C Bordereau col., 10.xi.2000, MZUSP 22695; Porto Seguro, lat 16,4694S, long 39,2803W, JP Constantini col., 17.xi.2016, MZUSP 26650. Espírito Santo: Sooretama, lat 19,0554S, long 40,1469W, RG Santos col., 24.xi.2014, MZUSP 24550. São Paulo: Santo André, Paranapiacaba, Estação Alto da Serra, lat 23,7833S, long 46,3166W, F Silvestri col., 1927, MZUSP 26343, 26344, 26345, 26346, 26347, 26348, 26349, 26350, 26351.

Notas de campo: forrageando imediatamente debaixo da serapilheira; no solo; em tronco caído.

Comparações: A espécie Ruptitermes pitan é muito maior que Ruptitermes reconditus (Tab. 22). A espécie Ruptitermes pitan possui nove ou mais cerdas grossas na coxa anterior enquanto Ruptitermes reconditus possui de 4-6. 


\section{DISCUSSÃO}

\section{Caracteres e variação}

Para 17 espécies (descritas e não descritas, listadas no começo da seção 4) a casta do alado não é conhecida. Considerando o observado para Anoplotermes e Disjunctitermes, os processos pré-molar e molar podem ser considerados boas características genéricas. 0 desconhecimento desta casta para algumas das espécies estudadas prejudica a compreensão sobre o valor informativo das estruturas e as decisões taxonômicas. Além disso, mais informação sobre a forma, cor e dimorfismo da forma da fontanela nos alados é necessária para compreender como essa característica varia entre espécies e entre gêneros. A fontanela dos alados de Patawatermes, Anoplotermes subterraneus, Aparatermes silvestrii pode ter formas singulares, que merecem investigação morfológica (quanto à variação intra- e intercolonial), histológica e funcional.

Com os primeiros resultados relativos à hipofaringe, considerou-se, a partir da comparação de duas espécies relativamente distantes morfologicamente, que existia um baixo custo-benefício. A microscopia de varredura das maxilas não trouxe novidade em relação ao exame dessa estrutura sob estereomicroscópio. Há alguma variação no número de cerdas na lacínia, mas nada consistente, existindo variação intra- e interespecífica.

As asas em Termitidae apresentam grande variação de nervura, variação que ocorre até em um mesmo espécime, e a redução das nervuras é uma característica geral para Isoptera. Neste trabalho não foi realizado um estudo cuidadoso das asas, mas observou-se uma tendência geral da presença de "micrasters" (Roonwal, 1983) e cerdas concentradas principalmente nas nervuras, mas também presentes em quantidade menor nas áreas membranosas. Parece haver alguma variação de cor das asas in vivo, que vai do cinza opaco até o iridescente, no entanto, não há registro de campo sobre essa característica, que não é visível no animal fixado. Também é importante considerar que boa parte dos alados está sem as asas nas amostras.

As espécies Gên. 1 sp. ES2, Gên. 1 sp. S5, Gên. 2 sp. MCH, Gên. 5 sp. V4, Gên. 7 sp. S7, Gên. 11 sp. V2, Gên. 9 sp. V3, Patawatermes turricola e Ruptitermes spp. apresentam órgãos deiscentes na região do tórax e porção anterior do abdômen. Na espécie Gên. 2 sp. MCH a característica não é visível no animal fixado em álcool, mas é extremamente 
visível no campo (Fig. 154, 155). As espécies de Aparatermes apresentam in vivo uma região toraco-abdominal bem dilatada e translúcida, característica que também é perdida no álcool (JPC, observação no campo). Assim, é preciso coletar amostras e conservá-las em fixadores específicos para histologia para compreender se estas estruturas são órgãos deiscentes ou glândulas salivares. Muitos operários de Patawatermes turricola e Gên. 9 sp. V3 aparecem com corpos globulosos evaginados ligados à região entre tórax e abdômen, mas conservando a estrutura dos escleritos e pleuritos intacta, diferente do processo de evisceração que ocorre em Ruptitermes spp., onde a região anterior do abdômen é destruída. Sob esteromicroscópio parece haver uma área mais esclerotizada na lateral da região onde ocorre a extroversão do órgão deiscente, mas de difícil visualização, ficando como indicativo para investigação futura.

De acordo com Noirot (2001), a moela dos operários em Apicotermitinae é caliciforme, muito reduzida, com nenhuma esclerotização e ornamentação empobrecida, no entanto, é preciso considerar que Noirot estudou poucos representantes neotropicais, e um estudo mais amplo dessa estrutura é necessário para saber se ela pode ser informativa ou não. 0 estudo da moela foi iniciado neste trabalho, mas não foi concluído, pois foi observada uma complexidade maior que a esperada, e há a necessidade de emprego de técnicas histológicas de coloração, e do estudo de um número maior de espécimes do que o previsto inicialmente. Nos operários de Anoplotermes banksi e Anoplotermes sp. 1 foram observados quatro pulvilli com escamas mais largas que compridas e espinhos nas margens. Quando observada in situ é possível ver as marcas da musculatura delimitando as pregas do cinturão colunar ("columnar belt”). No operário de Gênero 9 sp. V3, mesmo na estrutura in situ, não foi possível identificar pulvilli, e foram observadas apenas fileiras de espinhos, sem porção inflada.

O estudo da inserção dos túbulos de Malpighi foi especialmente difícil. Não houve avanço na identificação das estruturas, porque é preciso empregar técnicas histológicas, provavelmente com coloração especial.

A região interna do íleo foi estudada apenas preliminarmente nos operários das espécies Anoplotermes banski e Aparatermes abbreviatus. Foram observadas nas duas espécies padrão de escamas com forma e ornamentação diferente. A ornamentação interna do íleo é difícil de estudar nos Apicotermitinae pela forma alongada e tubular dessa estrutura, diferente do que ocorre nos operários de Syntermitinae (Rocha e Constantini, 2015). 
A válvula entérica é fundamental para a delimitação de espécies em alguns gêneros como, por exemplo, Anoplotermes, Patawatermes e Grigiotermes; mas não é fundamental para a delimitação de espécies em outros como, por exemplo, em Ruptitermes (Acioli e Constantino, 2015 apresentam uma chave de identificação que não usa a válvula entérica como caráter), Aparatermes e Tetimatermes. Ainda é necessário conhecer mais da diversidade de Apicotermitinae para entender se há um padrão na morfologia da válvula entérica para separação de grupos supraespecíficos.

Interessante notar que a região da válvula entérica extrovertida na pança (distal) não é necessariamente simétrica ou acompanha o padrão visto na região das pregas na face interna da válvula entérica. Considerando o proposto por Noirot (2001; Noirot e Noirot-Timothée, 1969) a parte extrovertida é uma continuidade da prega localizada internamente, e quando comparada com outros Termitidae, infere-se que a ornamentação quitinosa que aparecia naqueles grupos internamente na válvula entérica, foi exposta externamente na luz do assentamento da válvula entérica ao longo do processo evolutivo (Fig. 6). Seguindo esse raciocínio, em espécies em que apenas algumas das pregas apresentam a parte extrovertida (p. ex. Ruptitermes bandeirai e Anoplotermes parvus), teria ocorrido perda ou redução relacionada às das outras pregas.

\section{Considerações sobre a delimitação das espécies}

A delimitação de espécies no "Grupo Anoplotermes" é mais difícil que em outros grupos de cupim, pois a ausência da casta do soldado demanda que as outras duas castas, do alado e do operário, sejam estudadas para um bom diagnóstico. 0 observado no estudo de todo material reunido neste trabalho indica que existem poucas características exclusivas de uma espécie, e o que ocorre são combinações exclusivas de características. As características consideradas exclusivas foram alguns dos padrões de válvula entérica, e a forma da fontanela em alguns alados.

Foi possível para a maior parte do material estudado, definir espécies bem caracterizadas. No entanto, houve grande dificuldade em delimitar um grupo de amostras denominadas neste trabalho como Hydrecotermes sp. 1. Nestas amostras foi observada muita variação na pilosidade da cápsula cefálica, tamanho geral, e intumescência da tíbia anterior. Essas amostras foram comparadas com os tipos de Hydrecotermes arienesho e Hydrecotermes kawaii e concluiu-se que se tratava de outra espécie, ou grupo de espécies, do mesmo gênero. Fica o indicativo para que essas 
amostras sejam novamente analisadas usando morfometria e uma abordagem molecular.

\section{Considerações sobre o agrupamento em gêneros}

Para entender a melhor forma de agrupar as espécies de Apicotermitinae em gêneros, é indiscutível que os estudos taxonômicos na região neotropical devem ser continuados, bem como a construção de uma hipótese de filogenia dos representantes neotropicais de Apicotermitinae, combinando características morfológicas e moleculares. Dito isto, sabe-se da fragilidade da proposta aqui apresentada, mas as decisões são discutidas abaixo.

Algumas tentativas de compreender as relações dentro do "Grupo Anoplotermes" neotropical com o uso de marcadores moleculares têm sido realizadas nas publicações mais recentes. Nos trabalhos de Carrijo et al. (2015), Scheffrahn et al. (2017) e Castro et al. (2018) foi usado o DNA barcode (COI) na tentativa de conseguir alguma informação sobre grupos de espécies, no entanto, não foram usados os mesmos táxons nestas análises, o que resultou em agrupamentos diferentes em cada uma delas. Nos trabalhos de Bourguignon et al. $(2010,2016)$ foram usados como marcadores $12 \mathrm{~S}$ r RNA, 28S rRNA, COI e COII, porém no trabalho de 2010 não foi apresentada uma árvore, mas uma análise de distância genética para as espécies. A árvore apresentada no trabalho de 2016, apesar de ter poucos táxons terminais, tem suportes mais altos que as árvores usando apenas o COI (dos trabalhos citados acima). Alguns problemas comuns a todas as análises discutidas aqui, é o uso de poucos táxons, poucos marcadores moleculares, a falta de integração de caracteres morfológicos e a apresentação de táxons não descritos, sendo, portanto, difícil compreender como ocorre a evolução dos caracteres morfológicos nestas hipóteses.

$\mathrm{Na}$ descrição do gênero Humutermes os autores (Bourguignon et al. 2016) apontaram a dificuldade de separar as espécies alocadas neste novo gênero daquelas que chamaram de Anoplotermes sensu stricto (=Anoplotermes banksi, Anoplotermes pacificus, Anoplotermes janus e Anoplotermes parvus). A acomodação das espécies Humutermes krishnai e Humutermes noiroti em um novo gênero foi justificada pela diferença na válvula entérica, que nessas duas espécies é composta por uma armação de seis placas esclerotizadas e pela forma da fontanela do alado (caráter que apresenta variação dentro de Anoplotermes). É importante ressaltar que Anoplotermes abriga duas 
espécies, Anoplotermes janus e Anoplotermes parvus (tratadas por parte dos mesmos autores citados acima em Bourguignon et al. 2010), que também possuem uma porção armada da válvula entérica. A partir da comparação da morfologia externa, mandíbula e enrolamento do tubo digestório das espécies encontradas na Mata Atlântica e dos tipos, conclui-se que não há justificativa para a separação dos dois gêneros.

No trabalho de Bourguignon et al. (2016a) um grupo com Grigiotermes hageni, Amplucrutermes inflatus e Patawatermes nigripuntatus é recuperado com alto suporte. Essas três espécies são parecidas quanto à pilosidade da cápsula cefálica e ao enrolamento do tubo digestório e ainda assim os autores fizeram a opção por descrever novos gêneros. Ressalte-se que o tamanho dos ramos (número de mutações por sítio) neste agrupamento (com três gêneros) e no agrupamento com as espécies de Anoplotermes são similares.

No presente trabalho optou-se por uma abordagem na separação dos gêneros que reunisse espécies que compartilham algumas características que foram consideradas mais complexas (assentamento trilobado, lingueta mesentérica longa e inflada, presença de órgãos deiscentes, fileiras de cerdas grossas na tíbia anterior, no operário; forma e dimorfismo da fontanela no alado). Nesse sentido, optou-se por manter as espécies de Gênero 7, Gênero 8, Gênero 13 e Hydrecotermes (ver o item "comparações" na descrição de Hydrecotermes) separadas em diferentes gêneros.

A espécie Gên. 12 sp. P1C foi inicialmente alocada em Grigiotermes considerando as características da válvula entérica, sendo, no entanto separada pelo estado trilobado do assentamento da válvula entérica. Porém, optou-se por manter Grigiotermes sp. 1 junto com Grigiotermes hageni, apesar do padrão de pilosidade da cápsula cefálica ser diferente entre os operários dessas duas espécies. Não está claro ainda o quanto o caráter pilosidade é variável.

Um problema talvez mais espinhoso seja o das espécies próximas à Aparatermes (Anoplotermes brucei, Aparatermes abbreviatus, Aparatermes cingulatus, Aparatermes silvestrii, Gên. 1 sp. ES2, Gên. 11 sp. ES3) pois o padrão da válvula entérica é parecido e não se sabe o quanto existe de variação neste padrão. A morfologia externa dessas espécies é parecida diferindo em características, nem sempre fáceis de delimitar (ver comparações sob Gên. 11). 


\section{Decisões taxonômicas futuras}

A partir dos tipos estudados (Tab. 1), foi possível determinar a identidade de algumas das espécies e assim, estabelecer as decisões taxonômicas que deverão ser tomadas através de publicações. A seguir, estão arroladas as futuras mudanças com os principais caracteres diagnósticos que as embasaram.

Anoplotermes distans deve tornar-se sinônimo júnior de Anoplotermes meridianus com base na presença de lingueta mesentérica curta, inflada, assentamento da válvula entérica trilobado e padrão de escamas da válvula entérica.

Anoplotermes meridianus deve ser transferido futuramente para o gênero Longustitermes pela similaridade no padrão do tubo digestório, corpo alongado e pilosidade da cápsula cefálica.

Anoplotermes pyriformis deve tornar-se sinônimo júnior de Anoplotermes subterraneus com base na forma da fontanela das fêmeas aladas, e características externas do alado.

Anoplotermes subterraneus deve ser tranferida para Amplucrutermes com base no enrolamento do tubo digestório, dentição, pilosidade da cápsula cefálica e intumescência da tíbia anterior.

Aparatermes silvestrii deve ser transferida para um novo gênero com base em diferenças na fontanela do alado, no comprimento do íleo e do assentamento da válvula entérica no operário.

A espécie Ruptitermes bandeirai deve ser transferida para um novo gênero, pois, apesar da presença de glândulas deiscentes, característica dada como diagnóstica do gênero Ruptitermes até o presente (Acioli e Constantino, 2015), a espécie não compartilha com as demais os tergitos esclerotizados escurecidos, cerdas grossas na coxa anterior, o padrão de válvula entérica e assentamento da válvula entérica trilobado. Além disso, uma série de outras espécies estudadas no material da Mata Atlântica também apresentam órgãos deiscentes, e o uso dessa característica como diagnóstico de Ruptitermes não se sustenta e uma nova diagnose deve ser proposta.

As vinte novas espécies serão publicadas.

\section{Distribuição das Amostras Estudadas ao longo da Mata Atlântica}

Não faz parte do escopo deste trabalho propor hipóteses de biogeografia para as espécies de Apicotermitinae que ocorrem na Mata Atlântica. Os mapas fornecidos se 
limitam a mostrar as localidades na Mata Atlântica onde as espécies foram encontradas. Para todas as espécies descritas houve ampliação da área de ocorrência conhecida, apesar de que não terem sido incluídas as localidades anteriormente conhecidas.

As espécies Anoplotermes meridianus e Hydrecotermes sp. 1 foram as únicas encontradas ao longo de toda a área de Mata Atlântica amostrada.

A maior parte das espécies se concentra ou ao norte ou ao sul (Figs. 316-334), com algumas poucas espécies ocorrendo apenas na região central da Mata Atlântica. Um padrão de ocorrência ao norte ou ao sul do Rio Doce, em espécies correlatas foi observado entre Anoplotermes banksi e Anoplotermes pacificus; Disjunctitermes sp. 1 e Disjunctitermes sp. 2; Grigiotermes hageni e Grigiotermes sp. 1; Patawatermes nigripuntatus e Patawatermes turricola; e Gên. 5 sp. V4 e Ruptitermes bandeirai. Este padrão norte-sul pode ser um interessante objeto de estudo biogeográfico, visto que existem evidências, de que este seja um padrão paleoclimático, e é consistente com a distribuição de outros grupos zoológicos (Carnaval e Moritz, 2008; De Mello Martins, 2011).

\section{Morfometria}

Uma correlação negativa entre o índice da tíbia e a largura da cabeça foi encontrada ( $\mathrm{r}$ de Pearson= -0,86; Tab. 5, Fig. 8) estando possivelmente relacionada ao hábito de forrageamento dos indivíduos, já que especula-se que espécies cujos indivíduos são grandes (largura da cabeça maior) como as de Ruptitermes e Aparatermes forrageiem na serapilheira (índice da tíbia baixo), enquanto espécies como Longustitermes e Anoplotermes (largura da cabeça menor) forrageiem no solo construindo túneis (alto índice da tíbia).

Observou-se ainda, embora não tenham sido gerados dados suficientes para uma afirmação concreta, que existe uma tendência ao aumento no tamanho dos espécimes à medida que se aproximam da linha do equador. Isso explicaria, por exemplo, porque os espécimes tipo, em muitos casos, descritos para localidades mais ao norte em relação ao Brasil, como a região da Guiana, por exemplo, são maiores do que os espécimes encontrados no Brasil. Essa observação deve ser testada com estudos morfométricos amplos intra- e intercoloniais e entre localidades. 


\section{CONCLUSÃO}

A partir dos dados levantados, este trabalho buscou traçar um panorama do que se conhece das espécies dos Apicotermitinae descritas, levantando os problemas, em especial os relacionados ao estado dos tipos de algumas espécies. Os objetivos propostos foram alcançados.

Ao fim, puderam ser identificadas, dentro do recorte do projeto, 35 espécies, 20 delas não descritas. 0 estudo dos tipos possibilitou a redescrição de espécies com identidade dúbia, e determinação das espécies de Anoplotermes que, pelas más condições de conservação dos tipos, continuarão com o status duvidoso.

Somando o estudo dos tipos e das amostras da Mata Atlântica, conclui-se que 62 espécies de Apicotermitinae podem ser identificadas hoje na Região Neotropical. Este número pode ser maior caso os tipos depositadas no USNM possam ser estudados e estejam em condições de identificação.

O esforço do estudo comparado ofereceu uma perspectiva de quais caracteres morfológicos são fundamendais para a delimitação das espécies, destacando o uso das mandíbulas, em especial a esquerda, de alados e operários para agrupamentos. Nesse sentido é importante o esforço de coleta na época das revoadas, para que estas informações sejam incluídas para as espécies em que a casta do alado não é conhecida. A presença e estado do segmento misto e a forma do assentamento da válvula entérica foram importantes para a separação de grupos de espécies parecidas.

Deste trabalho surgiram algumas possibilidades de futuras linhas para a pesquisa com os Apicotermitinae, como o estudo morfométrico da população de Anoplotermes pacificus da Estação Biológica de Boraceia, Salesópolis, (SP), para investigação da variação intra- e intercolonial, estudo que poderia se estender também ao longo da área de ocorrência de Anoplotermes pacificus para investigação da variação entre populações; estudo da variação da válvula entérica intra- e intercolonial em várias espécies; filogeografia de Anoplotermes meridianus, já que a espécie parece ter uma ampla área de ocorrência (considerando que Anoplotermes distans, cuja localidade tipo é na Bolívia, deve tornar-se sinônimo júnior) e estudos biogegráficos para compreensão da distribuição norte-sul das espécies na Mata Atlântica.

De todo o exposto aqui, entende-se que para uma filogenia dos Apicotermitinae neotropicais, ainda é necessário um esforço taxonômico que abarque as regiões do 
cerrado e caatinga, praticamente não explorados taxonomicamente para os Apicotermitinae, e também a Amazônia, onde existem esforços de outros laboratórios, e onde pelas coletas realizadas nos últimos anos existe grande riqueza e abundância de morfoespécies da subfamília (Carrijo, 2013- tese).

O material estudado aqui representa 9\% das amostras depositadas hoje no Museu de Zoologia da USP (Eliana Cancello, com. pessoal). 0 que significa que ainda restam outros 91\% das amostras a serem estudadas, e delas 3181 estão identificadas apenas até subfamília. Que o esforço realizado neste trabalho seja um incentivo para que outros taxonomistas se interessem em abraçar o desafio do estudo dos Apicotermitinae neotropicais. 


\section{REFERÊNCIAS}

Acioli, A. N., e Constantino, R. 2014. A taxonomic revision of the neotropical termite genus Ruptitermes (Isoptera, Termitidae, Apicotermitinae). Zootaxa, 4032(5): 451-492.

Acioli, A. N. 2007. Revisão Taxonômica e Relações Filogenéticas do Gênero Neotropical Ruptitermes Mathews, 1977 (Isoptera: Termitidae: Apicotermitinae). Programa Interinstitucional de Pós-Graduação em Biologia Tropical e Recursos Naturais da Amazônia. Manaus: INPA/UFAM.136 + viii p., ilust.

Ackerman, I. L., Constantino, R., Gauch, Jr, H. G., Lehmann, J., Riha, S. J. e Fernandes, E. C. M. 2009. Termite (Insecta: Isoptera) species composition in a primary rain forest and agroforests in Central Amazonia. Biotropica, 41:226-233.

Ahmad, M. 1976. The soldierless termite genera of the Oriental Region, with a note on their phylogeny (Isoptera : Termitidae). Pakistan Journal of Zoology, 8:105-123.

Banks, N. 1919. Antillean Isoptera. Bulletin of the Museum of Comparative Zoology 62 (10): 475-489+ 2 pls.

Banks, N. 1920. Part 1. Taxonomy. In N. Banks and T.E. Snyder, A revision of the Nearctic termites [Banks], with notes on the biology and distribution of termites [Snyder]: 1-85. United States National Museum Bulletin, 108: [i]-viii + 1-228 + 35 pls.

Beccaloni, G., e Eggleton, P. 2013. Order Blattodea. In: Zhang, Z.-Q.(Ed.) Animal Biodiversity: An Outline of Higher-level Classification and Survey of Taxonomic Richness (Addenda 2013). Zootaxa, 3703(1): 46-48.

Bitsch, C., e Noirot, C. 2002. Gut characters and phylogeny of the higher termites (Isoptera: Termitidae). A cladistic analysis. Annales de la Société entomologique de France, 38 (3): 201-210.

Bourguignon, T., Lo, N., Šobotník, J., Ho, S. Y., Iqbal, N., Coissac, E., Lee, M., Jendryka, M. M., Sillam-Dussès, D., Kř́žzová, B., Roisin, Y. e Evans, T. A. 2017. Mitochondrial phylogenomics resolves the global spread of higher termites, ecosystem engineers of the tropics. Molecular Biology and Evolution, 34(3): 589-597.

Bourguignon, T., Scheffrahn, R. H., Nagy, Z. T., Sonet, G., Host, B., e Roisin, Y. 2016a. Towards a revision of the Neotropical soldierless termites (Isoptera: Termitidae): 
redescription of the genus Grigiotermes Mathews and description of five new genera. Zoological Journal of the Linnean Society, 176(1):15-35.

Bourguignon, T., Lo, N., Cameron, S. L., Šobotník, J., Hayashi, Y., Shigenobu, S.Watanabe, D., Roisin, Y., Miura, T. e Evans, T. A. 2015. The evolutionary history of termites as inferred from 66 mitochondrial genomes. Molecular Biology and Evolution, 32(2):406-421.

Bourguignon, T., Scheffrahn, R. H., Křeček, J., Nagy, Z. T., Sonet, G., e Roisin, Y. 2010. Towards a revision of the Neotropical soldierless termites (Isoptera: Termitidae): redescription of the genus Anoplotermes and description of Longustitermes, gen. nov. Invertebrate systematics, 24(4):357-370.

Bourguignon, T., Leponce, M. e Roisin, Y. 2011. Beta-Diversity of termite assemblages among primary French Guiana rain forests. Biotropica, 43:473-479.

Brussaard, L. 1998. Soil fauna, guilds, functional groups and ecosystem processes. Applied Soil Ecology, 9: 123-135.

Burmeister, H. 1839. Termiten, weisse Ameisen. Termitina. In: H. Burmeister, Handbuch der Entomologie. Vol. 2:758-768. Berlin: Theod. Chr. Friedr. Enslin, xii + $1050+8$ pp.

Cancello, E. M. 1994. Termites from the Northeastern Brazilian formations. In: Lenoir, A., Arnold, G. e Lepage, M. (eds.). Les Insectes Sociaux. International Congress of IUSSI (International Union for the Study of Social Insects), XII. Paris. Villetaneuse, Université Paris Nord. p. 277.

Cancello, E. M., Silva, R. R., Vasconcellos, A., Reis, Y. T., e Oliveira, L. M. 2014. Latitudinal variation in termite species richness and abundance along the Brazilian Atlantic Forest hotspot. Biotropica, 46(4):441-450.

Carnaval, A. C., e Moritz, C. 2008. Historical climate modelling predicts patterns of current biodiversity in the Brazilian Atlantic forest. Journal of Biogeography, 35(7), 1187-1201.

Carrijo, T. F. 2013. Estudo da termitofauna (Insecta, Isoptera) da região do alto Rio Madeira, Rondônia. 143 p. Tese (Doutorado em Ciências) - Faculdade de Filosofia, Ciências e Letras de Ribeirão Preto, Universidade de São Paulo, São Paulo. 
Carrijo, T. F., Scheffrahn, R. H., e Křeček, J. 2015. Compositermes bani sp. n. (Isoptera, Termitidae, Apicotermitinae), a new species of soldierless termite from Bolivia. Zootaxa, 3941(2), 294-298.

Castro, D., Scheffrahn, R. H., e Carrijo, T. F. 2018. Echinotermes biriba, a new genus and species of soldierless termite from the Colombian and Peruvian Amazon (Termitidae, Apicotermitinae). ZooKeys, (748), 21.

Coaton, W.G.H. 1971. Five new termite genera from south west Africa (Isoptera: Termitidae). Cimbebasia (Series A) 2 (1): 1-34.

Constantino, R. 2018a. Reexamination of the identity and status of the termite taxa described by Czerwinski (1901) from southern Brazil (Isoptera: Termitidae). Zootaxa, 4370(3), 275-278.

Constantino, 2018b. Catalógo Online. Disponível em: http://164.41.140.9/catal/

Constantino, R. 2005. Padrões de diversidade e endemismo de térmitas no bioma Cerrado. In: Scariot, A.; Silva, J.C.S.; Felfili, J.M. (Ed.). Cerrado: ecologia, biodiversidade e conservação. Brasília: Ministério do Meio Ambiente, p. 319333.

Constantino, R.1999. Chave ilustrada para identificação dos gêneros de cupins (Insecta: Isoptera) que ocorrem no Brasil. Papéis Avulsos de Zoologia, 40(25):387-448.

Constantino, R. 1992. Abundance and diversity of termites (Insecta: Isoptera) in two sites of primary rain forest in Brazilian Amazonia. Biotropica, 24(3):420-430.

Couto, A. A., Albuquerque, A. C., Vasconcellos, A., e Castro, C. C. 2015. Termite assemblages (Blattodea: Isoptera) in a habitat humidity gradient in the semiarid region of northeastern Brazil. Zoologia (Curitiba), 32(4):281-288.

Cunha, H.F., Costa, D. A., e Brandão, D. 2006. Termite (Isoptera) assemblages in some regions of the Goiás State, Brazil. Sociobiology, 47 (2): 505-518.

Czerwinski, K.K. 1901. List and descriptions of the collections of termites (fam. Termitidae). Collections of the Zoological Cabinet of the Imperial Warsaw University, 7: i-v + 1-10. [em Russo]

Davies, R. G., Hernández, L. M., Eggleton, P., Didham, R. K., Fagan, L. L., e Winchester, N. N. 2003. Environmental and spatial influences upon species composition of a termite assemblage across Neotropical forest islands. Journal of Tropical Ecology, 19(5), 509-524. 
Deitz, L. L., Nalepa, C. e Klass. 2003. Phylogeny of the Dictyoptera re-examined (Insecta). Entomologische Abhandlungen, 61(1): 69-91.

Deligne, J. 1999. Functional morphology and evolution of a carpenter's plane-like tool in the mandibles of termite workers (Insecta Isoptera). Belgian Journal of Zoology, 129 (1): 201-218.

Desneux, J. 1956. Structures《 atypiques》 dans les nidifications souterraines d'Apicotermes lamani Sj.(Isoptera, Termitidae) misses en évidence par la radiographie. Insectes Sociaux, 3(2):277-281.

De Mello Martins, F. 2011. Historical biogeography of the Brazilian Atlantic forest and the Carnaval-Moritz model of Pleistocene refugia: what do phylogeographical studies tell us? Biological Journal of the Linnean Society, 104(3), 499-509.

DeSouza, O. F. F., Cancello, E. M. 2010 . Termites and ecosystem function. In: Kleber del Claro et al. (Org.). Encyclopedia of Life Support Systems. 1a. ed. Oxford: EOLSS Publishers, 6:142-159.

Djernæs, M., Klass, K. D., e Eggleton, P. 2015. Identifying possible sister groups of Cryptocercidae+ Isoptera: A combined molecular and morphological phylogeny of Dictyoptera. Molecular phylogenetics and evolution, 84:284-303.

Eggleton, P. 1994. Termites live in a pear-shaped world: a response to Platnick. Journal of Natural History, 28:1209-1212.

Eggleton, P., Bignell, D. E., Sands, W. A., Mawdsley, N. A., Lawton, J. H., Wood, T. G., e Bignell, N. C. 1996. The diversity, abundance and biomass of termites under differing levels of disturbance in the Mbalmayo Forest Reserve, southern Cameroon. Philosophical Transactions of the Royal Society of London, Series B: Biological Sciences, 351(1335): 51-68.

Eggleton, P. 1999. Termite species description rates and the state of termite taxonomy. Insectes Sociaux, 46: 1-5.

Eggleton, P. 2000. Global patterns of termite diversity. In T. Abe, D.E. Bignell, and M. Higashi (editors), Termites: evolution, sociality, symbioses, ecology. Dordrecht: Kluwer Academic Publishers, p. 25-51.

Emerson, A.E. 1925. The termites of Kartabo, Bartica District, British Guiana. Zoologica (New York), 6 (4): 291-459. 
Emerson, A.E. 1928b. Termites of the Belgian Congo and the Cameroon. Bulletin of the American Museum of Natural History, 57 (7): 401-574 + 19 pls, 24 mapas, e 79 figuras no texto.

Emerson, A.E. 1959. The African termite genera Firmitermes, Hoplognathotermes, Acutidentitermes, Duplidentitermes, and Heimitermes (Termitidae, Termitinae). American Museum Novitates, 1947: 1-42.

Engel, M..S., Grimaldi D.A., Nascimbene, P.C., Singh, H. 2011. The termites of Early Eocene Cambay amber, with the earliest record of the Termitidae (Isoptera). ZooKeys,148:105-123.

Engel, M. S., Grimaldi, D. A. e Krishna, K. 2009. Termites (Isoptera): Their phylogeny, classification, and rise to ecological dominance. American Museum Novitates, (3650): 1-27.

Evans, T. A., Dawes, T. Z., Ward, P. R., e Lo, N. 2011. Ants and termites increase crop yield in a dry climate. Nature Communications, 2:262.

Fontes, L.R. 1998. Novos aditamentos ao “Catálogo dos Isoptera do Novo Mundo," e uma filogenia para os gêneros neotropicais de Nasutitermitinae. In: Fontes, L.R e Filho E.B. (editors), Cupins: o desafio do conhecimento, 309-412. São Paulo: Fundação de Estudos Agrários Luiz de Queiroz, 512 pp.

Fontes, L. R. 1986. Two new genera of soldierless Apicotermitinae from the Neotropical region (Isoptera, Termitidae). Sociobiology, 12(2):285-297.

Fox-Dobbs, K., Doak, D. F., Brody, A. K., e Palmer, T. M. 2010. Termites create spatial structure and govern ecosystem function by affecting $\mathrm{N}_{2}$ fixation in an East African savanna. Ecology, 91(5): 1296-1307.

Galindo-Leal, C., e De Gusmão Câmara, I. (Eds.).2005. Mata Atlântica: biodiversidade, ameaças e perspectivas. Belo Horizonte: Conservation Intenational. $472 \mathrm{p}$.

Grassé, P.-P. 1982. Termitologia. Anatomie-physiologie-biologie-systématique des termites. Vol. 1, anatomie, physiologie, reproduction. Paris: Masson, xiv + 676 pp.

Grassé, P.-P. 1986. Termitologia. Anatomie-physiologie-biologie-systematique des termites. Vol. 3, comportement,socialite, ecologie, evolution, systematique. Paris: Masson, $x i+715$ pp.

Grassé, P.-P. 1943. Description et éthologie de Rostrotermes cornutus, n. g., n. sp., termite à soldat hypertélique. Archives de Zoologie Expérimentale et Générale, 83 (2): 71-82. 
Grassé, P.-P. e Noirot, C. 1955. Apicotermes arquieri (Isoptère): ses constructions, sa biologie. Considérations générales sur la sous famille des Apicotermitinae. Annales des Sciences Naturelles, 16:345-388.

Giesbrecht, R.M. 2018. Estações ferroviárias do Brasil. Disponível em: http://www.estacoesferroviarias.com.br/index.html. Acesso em: 07/09/2018.

Gontijo, T. A., e Domingos, D. J. 1991. Guild distribution of some termites from cerrado vegetation in south-east Brazil. Journal of Tropical Ecology, 7(4):523-529.

Hagen, H.A. 1855. Monographie der Termiten. Linnaea Entomologica, 10: 1-144, 270 325.

Hagen, H.A. 1858. Monographie der Termiten. Linnaea Entomologica, 12: i-iii + 4-342 $+459+3$ pls.

Hagen, H.A. 1860. Nachtrag zur Monographie der Termiten. Linnaea Entomologica, 14: $100-128$.

Higashi, M., N. Yamamura, and T. Abe. 2000. Theories on the sociality of termites. In: Abe, T., Bignell, D.E and Higashi, M. (editors), Termites: evolution, sociality, symbioses, ecology: 169-187. Dordrecht: Kluwer Academic Publishers, xxii + 466 pp.

Holmgren, N. 1912. Termitenstudien 3. Systematik der Termiten. Die Familien Metatermitidae. Konglia Svenska Vetenskapsakademiens Handlingar, 48 (4): $1-166$.

Holt, J. A., e Lepage, M. 2000. Termites and soil properties. In: Abe, T., Bignell, D.E and Higashi, M. (editors), Termites: evolution, sociality, symbioses, ecology: 389-407. Dordrecht: Kluwer Academic Publishers, xxii + 466 pp.

Inward, D., Beccaloni, G. e Eggleton, P. 2007a. Death of an order: a comprehensive molecular phylogenetic study confirms that termites are eusocial cockroaches. Biology Letters, 3: 331-335.

Inward, D.J., Vogler, A.P. e Eggleton, P. 2007b. A comprehensive phylogenetic analysis of termites (Isoptera) illuminates key aspects of their evolutionary biology. Molecular phylogenetics and evolution, 44(3): 953-967.

Jones, C.G., Lawton, J. H. e Shachak, M. 1994. Organisms as ecosystem engineers. Oikos, 69: 373-386. 
Jouquet, P., Bottinelli, N., Shanbhag, R. R., Bourguignon, T., Traoré, S., e Abbasi, S. A. 2016. Termites: the neglected soil engineers of tropical soils. Soil Science, 181(3/4), 157-165.

Kaiser, P. 1953. Anoplotermes pacificus, eine mit Pflanzenwurzeln vergesellschaftet lebende Termite. Mitteilungenaus dem Hamburgischen Zoologischen Museum und Institut, 52: 77-92.

Kambhampati, S., e Eggleton, P. 2000. Taxonomy and phylogeny of termites. . In: Abe, T., Bignell, D.E and Higashi, M. (editors), Termites: evolution, sociality, symbioses, ecology: 1-23. Dordrecht: Kluwer Academic Publishers, xxii + 466 pp.

Kirton, L. G., e Azmi, M. 2005. Patterns in the relative incidence of subterranean termite species infesting buildings in peninsular Malaysia. Sociobiology, 46(1):1-15.

Klass, K. e Meier, R. 2006. A phylogenetic analysis of Dictyoptera (Insecta) based on morphological characters. Entomologische Abhandlungen, 63 (1-2): 3-50.

Klass, K., Nalepa, C. e Lo, N. 2008. Wood-feeding cockroaches as models for termite evolution (Insecta: Dictyoptera): Cryptocercus vs. Parasphaeria boleiriana. Molecular Phylogenetics and Evolution, 46 (3): 809-817.

Krishna, K. 1968. Phylogeny and generic reclassification of the Capritermes complex (Isoptera, Termitidae, Termitinae). Bulletin of the American Museum of Natural History, 138 (5): 261-323.

Krishna, K. 1970. Taxonomy, phylogeny, and distribution of termites. In: Krishna, K e Weesner, F.M. (editors). Biology of termites. New York: Academic Press. Vol. 2, p. 127-152.

Krishna, K., e Grimaldi, D. 2009. Diverse rhinotermitidae and termitidae (Isoptera) in dominican amber. American Museum Novitates, 3640:1-48.

Krishna, K., Grimaldi, D. A., Krishna, V. e Engel, M. S. 2013. Treatise on the Isoptera of the world. Bulletin of the American Museum of Natural History. (377):1-2704.

Kristensen, N. P. 1981. Phylogeny of insect orders. Annual Review of Entomology, 26 (1): 135-157.

Lax, A. R., e Osbrink, W. L. 2003. United States Department of Agriculture-agriculture research service research on targeted management of the Formosan subterranean termite Coptotermes formosanus Shiraki (Isoptera: Rhinotermitidae). Pest management science, 59(6-7):788-800. 
Legendre, F., Nel, A., Svenson, G. J., Robillard, T., Pellens, R., e Grandcolas, P. 2015. Phylogeny of Dictyoptera: dating the origin of cockroaches, praying mantises and termites with molecular data and controlled fossil evidence. PloS one, 10(7), e0130127.

Legendre, F., Whiting, M. F., Bordereau, C., Cancello, E. M., Evans, T. A. e Grandcolas, P. 2008. The phylogeny of termites (Dictyoptera: Isoptera) based on mitochondrial and nuclear genes: implications for the evolution of the worker and pseudergate castes, and foraging behaviors. Molecular Phylogenetics and Evolution, 48: 615- 627.

Lo, N., e Eggleton, P. 2011. Termite phylogenetics and co-cladogenesis with symbionts. In: Bignell, D. E., Roisin, Y., e Lo, N. (Eds.). Biology of Termites: A Modern Synthesis. Springer Netherlands. p. 27-50.

Lo, N., Bandi, C., Watanabe, H., Nalepa, C. e Beninati, T. 2003. Evidence for cocladogenesis between diverse dictyopteran lineages and their intracellular endosymbionts. Molecular Biology and Evolution, 20(6): 907-913.

Malik, M. U., Javed, H., e Ayyaz, M. 2015. Evaluation of different groundnut Arachis hypogea L. cultivars against termites, Odontotermes obesus (Rambur) in Rawalpindi, PakistAnoplotermes Turkish Journal of Agriculture-Food Science and Technology, 3(6): 448-452.

Mathews, A.G.A. 1977. Studies on Termites from the Mato Grosso State, Brazil. Rio de Janeiro: Academia Brasileirade Ciências, 267 pp.

Milano, S., and L.R. Fontes. 2002. Cupim e cidade: implicações ecológicas e controle. São Paulo: Conquista Artes Gráficas, 141 pp.

Miller, L. R. 1984. Invasitermes, a new genus of soldierless termites from northern Australia (Isoptera: Termitidae). Journal of the Australian Entomological Society, 23:33-37.

Morellato, L. P. C. e Haddad, C.F.B. 2000. Introduction: the Brazilian Atlantic Forest. Biotropica, 32: 786-792.

Myers, N., Mittermeyer, R.A, Mittermeyer,C.G., Fonseca, G.A.B. e Kent, J. 2000. Biodiversity hotspots for conservation priorities. Nature, 403: 853-858.

Müller, F. 1873. Beiträge zur Kenntniss der Termiten. Jenaische Zeitschrift für Medizin und Naturwissenschaft, 7 (3):333-358, 451-463. 
Nation, J. L. 1983. A new method using hexamethyldisilazane for preparation of soft insect tissues for scanning electron microscopy. Stain technology, 58(6):347-351. Neves, D. M., Dexter, K. G., Pennington, R.T., Valente, A. S. M., Bueno, M. L., Eisenlohr, P. V., Fontes, M.A.L., Miranda, P. L. S., Moreira, S. N., Rezende, V. L., Saiter, F.Z., Oliveira-Filho, A. T. 2017. Dissecting a biodiversity hotspot: The importance of environmentally marginal habitats in the Atlantic Forest Domain of South America. Diversity and Distributions, 23(8), 898-909.

Noirot, C., and C. Noirot-Timothée. 1969. The digestive system. In: K. Krishna and F.M. Weesner (editors), Biology of termites. Vol. 1: 49-88. New York: Academic Press, xiii +598 pp.

Noirot, C. 1970. The nests of termites. In: Krishna, K. e Weesner, F.M. (editors). Biology of termites. New York: Academic Press. Vol. 2, 73-125.

Noirot, C. 2001. The gut of Termites (Isoptera) comparative anatomy, systematics, phylogeny. II. Higher Termites (Termitidae). Annales de la Société Éntomologique de France, 37(4):431-471.

Oliveira, D. E., Carrijo, T. F., e Brandão, D. 2013. Species Composition of Termites (Isoptera) in Different Cerrado Vegetation Physiognomies. Sociobiology, 60(2):190-197.

Oliveira-Filho, A. T. e Fontes, M. A. L. 2000. Patterns of floristic differentiation among Atlantic forests in southeastern Brazil, and the influence of climate. Biotropica, 32: 903-913.

Palin, O. F., Eggleton, P., Malhi, Y., Girardin, C. A. J., Rozas-Dávila, A. e Parr, C. L. 2011. Termite diversity along an Amazon-Andes elevation gradient, Peru. Biotropica, 43:100-107.

Papavero, N. 1971. Essays on the history of neotropical dipterology: with special reference to collectors (1750-1905). Vol. 1. Museu de Zoologia, Universidade de São Paulo. 216 p.

Poiani, S. B., e Costa-Leonardo, A. M. 2016. Dehiscent organs used for defensive behavior of kamikaze termites of the genus Ruptitermes (Termitidae, Apicotermitinae) are not glands. Micron, 82:63-73.

QGIS Development Team. 2018. QGIS Geographic Information System. Open Source Geospatial Foundation Project. Disponível em: <http://qgis.osgeo.org $>$. 
Reis, Y.T. 2007. Comparação da riqueza de Isoptera entre as florestas ombrófilas densas, mesófilas de altitude e matas-de-cipó de altitude, no Domínio Atlântico do sul da Bahia. 97 p. Tese (Doutorado em Ciências) - Faculdade de Filosofia, Ciências e Letras de Ribeirão Preto, Universidade de São Paulo, São Paulo.

Ribeiro, M. C., Metzger, J.P., Martensen, A.C., Ponzoni, F.J. e Hirota, M.M. 2009. The Brazilian Atlantic Forest: how much if left, and how is the remaining forest distributed? Implications for conservation. Biological Conservation, 142: 11411153.

Roonwal, M.L. 1970a. Termites of the Oriental region. In: Krishna, K. e Weesner, F.M. (editors). Biology of termites. New York: Academic Press. Vol. 2, 315-391.

Roonwal, M.L. 1970b. Measurements of termites (Isoptera) for taxonomic purposes. Journal of the Zoological Societyof India, 21 (1): 9-66.

Roonwal, M.L. 1958. Recent work on termite research in India (1947-57). Transactions of the Bose Research Institute, 22: 77-100.

Roonwal, M.L., and O.B. Chhotani. 1966. Soldier and other castes in the termite genus Speculitermes and the phylogeny of the Anoplotermes-Speculitermes complex. Biologisches Centralblatt, 85 (2): 183-210.

Roonwal, M.L., and O.B. Chhotani. 1960. Soldier caste found in the termite genus Speculitermes. Science and Culture 26 (3): 143-144.

Roonwal, M.L., and P.K. Sen-Sarma. 1960. Contributions to the systematics of Oriental termites. Indian Council of Agricultural Research Monograph, 1: i-xiv + 1-407.

Rust, M. K., e Su, N. Y. (2012). Managing social insects of urban importance. Annual review of entomology, 57, 355-375.

Salmon, J. T. 1951. Polyvinyl alcohol as a mounting medium in microscopy.The Microscope, 8(6): 139-142.

Sands, W.A. 1972. The soldierless termites of Africa (Isoptera, Termitidae). Bulletin of the British Museum (Natural History), Supplement, 18:1-244.

Scheffrahn, R.H., J. Křeček, J.A. Chase, B. Maharajh, and J.R. Mangold. 2006. Taxonomy, biogeography, and notes on termites (Isoptera: Kalotermitidae, Rhinotermitidae, Termitidae) of the Bahamas and Turks and Caicos Islands. Annals of the Entomological Society of America, 99 (3): 463-486. 
Scheffrahn, R. H. 2013. Compositermes vindai (Isoptera: Termitidae: Apicotermitinae), a new genus and species of soldierless termite from the Neotropics. Zootaxa, 3652(3):381-391.

Scheffrahn, R. H., Carrijo, T. F., Postle, A. C., e Tonini, F. 2017. Disjunctitermes insularis, a new soldierless termite genus and species (Isoptera, Termitidae, Apicotermitinae) from Guadeloupe and Peru. ZooKeys, (665), 71.

Schelemmermeyer, T. 2000. Levantamento da termitofauna da Estação Biológica de Boracéia, Salesópolis, SP. 60 p. Tese (Doutorado em Ciências) - Faculdade de Filosofia, Ciências e Letras de Ribeirão Preto, Universidade de São Paulo, São Paulo.

Scudder, S.H. 1862. Materials for a monograph of North American Orthoptera. Boston Journal of Natural History, 7: 409-480.

Silvestri, F. 1901. Nota preliminare sui Termitidi sud-americani. Bollettino dei Musei di Zoologia ed Anatomia Comparata della Reale Università di Torino, 16 (389): $1-8$.

Silvestri, F. 1914a. Contribuzione alla conoscenza dei Termitidi e Termitofili dell'Africa occidentale. I. Termitidi. Bollettino del Laboratorio di Zoologia Generale e Agraria della Reale Scoula Superiore d'Agricoltura, Portici 9: 1-146.

Sjöstedt, Y. 1926. Revision der Termiten Afrikas. 3. Monographie. Kungliga Svenska Vetenskaps-Akademiens Handlingar, (3) 3 (1): 1-419 + 16 pls.

Snyder, T.E. 1922. New termites from Hawaii, Central and South America, and the Antilles. Proceedings of the United States National Museum, 61 (20): 1-32 + 5 pls.

Snyder, T.E. 1923. Three new termites from the Canal Zone, Panama. Proceedings of the Entomological Society of Washington, 25 (5-6): 126-131.

Snyder, T.E. 1924. Descriptions of new species and hitherto unknown castes of termites from America and Hawaii. Proceedings of the United States National Museum, 64 (6): $1-40+5$ pls.

Snyder, T.E. 1926. Termites collected on the Mulford Biological Exploration to the Amazon Basin, 1921-1922. Proceedings of the United States National Museum, 68 (14): $1-76+3$ pls.

Snyder, T.E. 1934. Two new termites from Costa Rica. Proceedings of the Biological Society of Washington, 47:95-97. 
Snyder, T.E. 1949. Catalog of the termites (Isoptera) of the world. Smithsonian Miscellaneous Collections, 112: 1-490.

Snyder, T.E. 1955. Anoplotermes brucei, new species, from Bolivia (Isoptera, Termitidae). Proceedings of the Entomological Society of Washington, 57 (6): 300.

Snyder, T.E. 1959. New termites from Venezuela, with keys and a list of the described Venezuelan species. American Midland Naturalist, 61 (2): 313-321.

Sugimoto, A., Bignell, D. E., e MacDonald, J. A. (2000). Global impact of termites on the carbon cycle and atmospheric trace gases. In: Termites: evolution, sociality, symbioses, ecology (pp. 409-435). Springer Netherlands.

Šobotník, J., D. Sillam-Dussès, F. Weyda, A. Dejean, Y. Roisin, R. Hanus, and T. Bourguignon. 2010b. The frontal gland in workers of Neotropical soldierless termites. Naturwissenschaften, 97: 495-503.

Terry, M.D. e Whiting, M.F. 2005. Mantophasmatodea and phylogeny of the lower neopterous insects. Cladistics, 21(3):240-257.

Torre-Bueno, J.R., Tulloch, G.S. e Schuh, R.T. 1989. The Torre-Bueno glossary of entomology. New York Entomological Society, 840 p.

Vignes-Lebbe R, Chesselet P, Diep Thi M-H (2016) Xper3: new tools for collaborating, training and transmitting knowledge on botanical phenotypes. In: Botanists of the twenty-first century: roles, challenges and opportunities. Noëline R. Rakotoarisoa, Stephen Blackmore and Bernard Riera, Paris, 228-239.

Ware, J. L., Grimaldi, D. A., \& Engel, M. S. 2010. The effects of fossil placement and calibration on divergence times and rates: an example from the termites (Insecta: Isoptera). Arthropod structure \& development, 39(2-3): 204-219.

Wasmann, E. 1897. Termiten von Madagaskar und Ostafrika. (Voeltzkow, Wissenschaftliche Ergebnisse der Reisen in Madagaskar und Ost-Afrika, 18891895). Abhandlungen der Senckenbergischen Naturforschenden Gesellschaft, 21 (1): 137-182 + 2 pls.

Wasmann, E. 1902. Termiten, Termitophilen und Myrmekophilen gesammelt auf Ceylon von Dr. W. Horn 1899, mit anderm ostindischen Material bearbeitet. Zoologische Jahrbücher, Abteilung für Systematik, Ökologie und Geographie der Tiere, 17 (1): 99-164 + 2 pls.

Weesner, F.M. 1969. External anatomy. In: K. Krishna and F.M. Weesner (editors), Biology of termites. Vol. 1:19-47. New York: Academic Press, xiii + 598 pp. 
Weidner, H. 1974. Beiträge zur Kenntnis der Termiten Angolas, hauptsächlich auf Grund der Sammlungen und Beobachtungen von A. de Barros Machado (3. Beitrag). Publicações Culturais da Companhia de Diamantes de Angola, 88: 13-78.

Wheeler, W.C., Whiting, M., Wheeler, Q.D. e Carpenter, J. M. 2001. The phylogeny of the extant hexapod orders. Cladistics, 17(2):113-169.

Wood, T.G. e Sands, W.A. 1978. The role of termites in ecosystems. In: Brian, M.V. (Ed.). Production ecology of ants and termites. Cambridge, Cambridge University Press. p. 245-292. 
UNIVERSIDADE DE SÃO PAULO

MUSEU DE ZOOLOGIA

Joice Paulo Constantini

\section{Estudo taxonômico dos Apicotermitinae da Mata Atlântica}

Volume II

-São Paulo- 


\section{JOICE PAULO CONSTANTINI}

Estudo taxonômico dos Apicotermitinae da Mata Atlântica

Volume II

Versão corrigida

Tese apresentada ao Museu de Zoologia da Universidade de São Paulo para obtenção do título de Doutora em Ciências.

Área de Concentração: Sistemática, Taxonomia Animal e Biodiversidade

Orientadora: Eliana Marques Cancello

-São Paulo- 
Autorizo a reprodução e divulgação total ou parcial deste trabalho, por qualquer meio convencional ou eletrônico, para fins de estudo e pesquisa, desde que citada a fonte.

\author{
Catalogação na Publicação \\ Serviço de Biblioteca e Documentação \\ Museu de Zoologia da Universidade de São Paulo \\ Ficha catalográfica: Dione Seripierri - CRB8/3805
}

Constantini, Joice Paulo

Estudo taxonômico dos Apicotermitinae da Mata Atlântica./ Joice Paulo Constantini; orientadora Eliana Marques Cancello. São Paulo, 2018.

$2 \mathrm{v}$.

Versão corrigida

Tese Doutorado - Programa de Pós-Graduação em Sistemática, Taxonomia e Biodiversidade, Museu de Zoologia, Universidade de São Paulo, 2018. 
Nome: Constantini, Joice Paulo

Título: Estudo taxonômico dos Apicotermitinae da Mata Atlântica

Tese apresentada ao Museu de Zoologia da Universidade de São Paulo para obtenção do título de Doutora em Ciências

Aprovada em: 11/10/2018

Banca Examinadora

Banca Examinadora

Profa Dra Eliana Marques Cancello - presidente da banca

Instituição: Museu de Zoologia da USP

Profa Dra Fabiana E. Casarin dos Santos

Instituição: Universidade Federal de São Paulo

Prof. Dr. Ives Haifig

Instituição: Universidade Federal do ABC

Prof. Dr. Agno Nonato Serrão Acioli

Instituição: Universidade Federal do Amazonas

Dr. Maurício Moura Rocha

Instituição: Museu de Zoologia da USP 


\section{Resumo}

Constantini, JP. 2018. Estudo taxonômico dos Apicotermitinae da Mata Atlântica

Palavras-chave: cupins, térmitas, morfologia comparada, operários, tubo digestório

Apesar de sua relevância ecológica, os Apicotermitinae neotropicais foram taxonomicamente pouco estudados, e nenhum trabalho abrangente de morfologia comparada foi feito sobre eles. Portanto, há uma lacuna na compreensão da variação apresentada por alguns caracteres (especialmente do tubo digestório) em todo o grupo. A morfologia interna e externa de 600 amostras de Apicotermitinae da Mata Atlântica depositadas no MZUSP, juntamente com os tipos do American Museum of Natural History (Nova Iorque) e do Smithsonian Institution National Museum (Washington, DC), foi estudada. 0 tubo digestório, incluindo a válvula entérica, foi analisado para cada espécie tratada aqui. Foram identificadas 35 espécies, sendo 20 delas ainda não descritas, e outras 15 espécies já conhecidas, cujas áreas de distribuição foram ampliadas. 0 estudo do material tipo possibilitou a melhoria das descrições de espécies, cujos diagnósticos eram problemáticos. As descrições e redescrições de todas as espécies foram incluídas, bem como ilustrações das principais características, estudo morfométrico e mapas de amostragem. Também foram incluídos comentários sobre o status do material tipo, um breve estudo comparativo de todas as espécies neotropicais e uma chave de identificação baseada nos operários para essas espécies. O estudo comparado deu suporte para novas hipóteses de agrupamento das espécies no nível de gênero, e permitiu avaliar caracteres informativos que têm sido negligenciados em artigos publicados recentemente, como: diferenças nas mandíbulas de operários e alados da mesma espécie, especialmente na região molar, dimorfismo sexual nos alados, presença de órgãos deiscentes no tórax e nos primeiros segmentos abdominais do operário. Conclui-se que é fundamental o estudo da morfologia externa e interna do operário e morfologia externa do alado de forma combinada para um bom diagnóstico em nível específico e genérico, não considerando apenas uma característica (como a válvula entérica) para a separação de táxons. As descrições desses novos táxons permitirão estudos faunísticos comparáveis, levando a um melhor entendimento desse grupo nos ecossistemas neotropicais. 


\begin{abstract}
Constantini, JP. 2018. Taxonomic study of Atlantic Forest Apicotermitinae
\end{abstract}

Keywords: termites, comparative morphology, workers, digestive tube

Despite their ecological relevance, the Neotropical soldierless termites were not taxonomically studied enough, and no comprehensive comparative morphology study has been done. Therefore, there is a gap in the understanding of the character variation (mainly those of the gut) in the whole group. External and internal morphology of 600 samples of Apicotermitinae from the Atlantic Forest housed in the MZUSP were studied, along with the types from the American Museum of Natural History (New York) and the Smithsonian Institution National Museum (Washington, DC). The digestive tube, including the enteric valve, of each species herein treated were studied. Thirty five species were identified in total, out of which 20 are undescribed, and the other 15 already described have had an extension of their known distribution. The study of the type material have improved the descriptions of species, whose diagnosis were problematic. Descriptions and re-descriptions of all species were provided, as well as illustrations of the main characteristics, morphometric study and sampling maps. There were also comments on the status of the type material, and a brief comparative study of all Neotropical species plus an identification key for these, based on workers. The comparative study supports the new hypotheses of grouping species at the genus level, and allowed an evaluation of the informative characters often neglected in recent published articles, such as: differences in the mandibles of workers and imagoes of the same species, mainly in the molar region; alate sexual dimorphism; presence of dehiscent organs in the thorax and first abdominal segments in workers. In conclusion, a combined study of both the external and internal morphology of the worker and the external morphology of the alate is fundamental to diagnose both the specific and generic level well, not just taking into consideration one characteristic (such as the enteric valve) to split taxons. Descriptions of the new taxa will enable comparisons among faunistic studies already published, leading to a better understanding of this group in Neotropical ecosystems. 
Sumário

\section{VOLUME I}

1. Introdução

1.1. Histórico Taxonômico dos Apicotermitinae da Região Neotropical ........................................................17

1.2. Justificativa para o recorte adotado neste trabalho ………………………………………………………..20

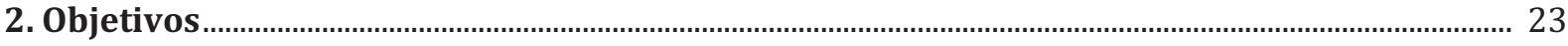

3. Material e Métodos …………………....................................................................................................... 24

3.1. Lista de Acrônimos das instituições citadas .....................................................................................................24

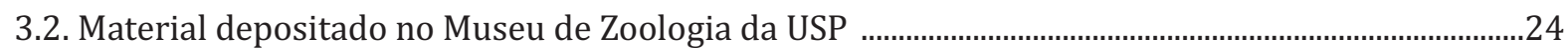

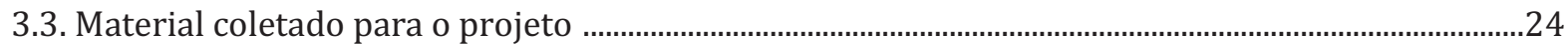

3.4. Visita à coleção de Isoptera do Americam Museum of Natural History ………………………………...25

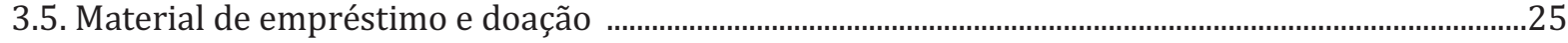

3.6. Estudo da morfologia externa e interna …………..................................................................................25

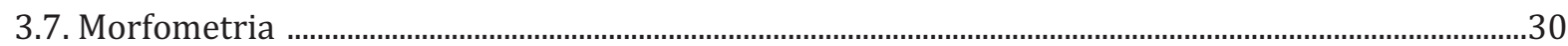

3.8. Ilustração, mapa e material examinado ........................................................................................................31

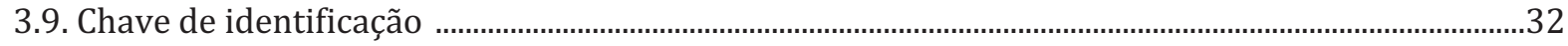

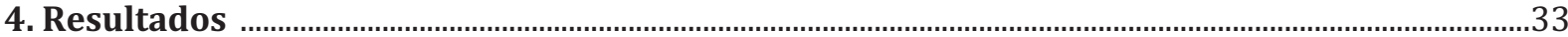

4.1. Apicotermitinae da Região Neotropical ("Grupo Anoplotermes") ..........................................................34

4.2. Chave para os operários das espécies e grupos de Apicotermitinae neotropicais ............................37

4.3. Redescrições e considerações sobre o status de parte dos tipos de Apicotermitinae ......................40

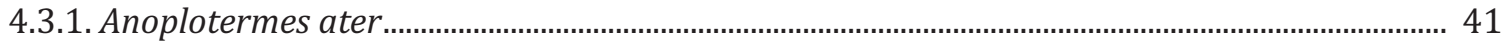

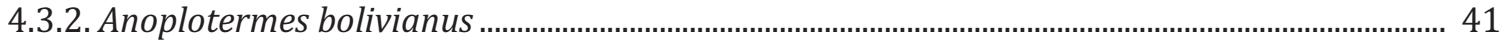

4.3.3. Anoplotermes brucei …………………………………................................................................... 42

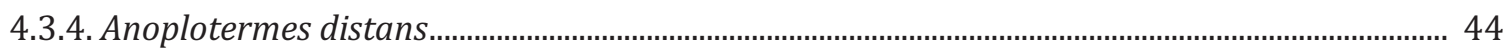

4.3.5. Anoplotermes gracilis ................................................................................................................ 44

4.3.6. Anoplotermes grandifons .................................................................................................................. 45

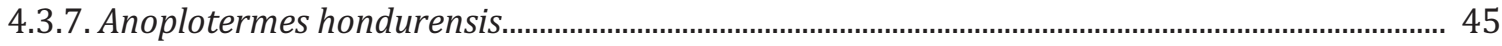

4.3.8. Anoplotermes howardi ................................................................................................................... 45

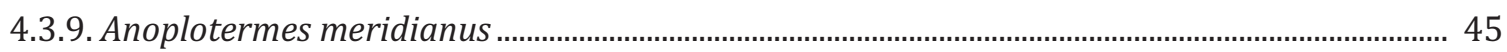

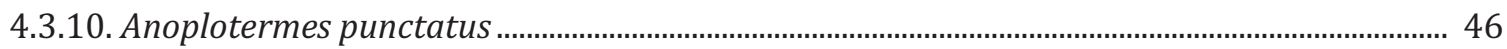

4.3.11. Anoplotermes pyriformis ............................................................................................................... 47

4.3.12. Anoplotermes rotundus .............................................................................................................. 48

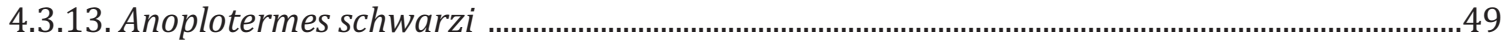

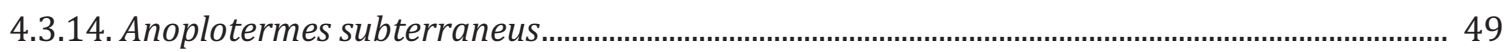

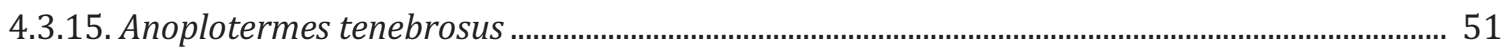

4.3.16. Aparatermes abbreviatus ................................................................................................. 51

4.3.17. Anoplotermes cingulatus ................................................................................................................ 52 
4.3.18. Anoplotermes silvestrii

4.4. Descrições e redescrições das espécies de Apicotermitinae da Mata Atlântica ..................................54

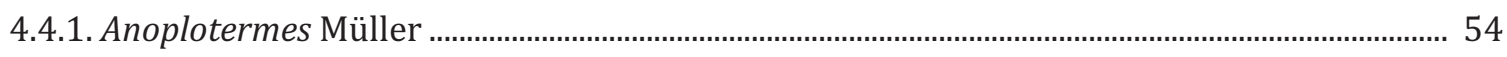

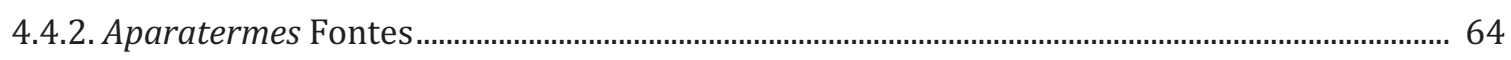

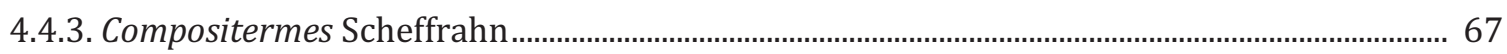

4.4.4. Disjunctitermes Scheffrahn ................................................................................................................ 69

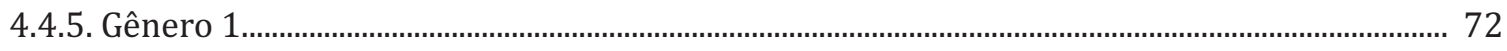

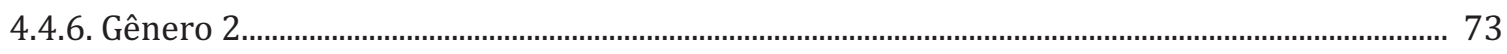

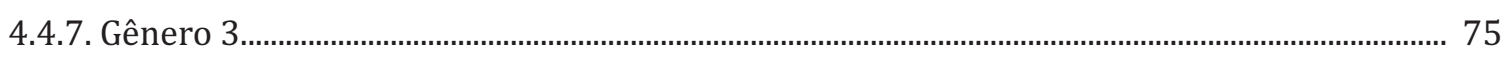

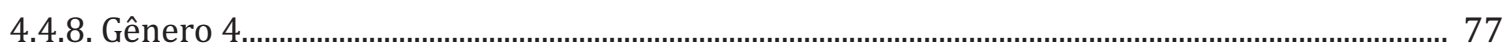

4.4.9. Gênero 5

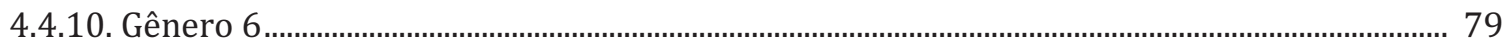

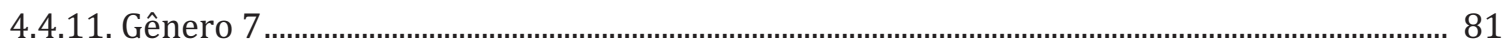

4.4.12. Gênero 8

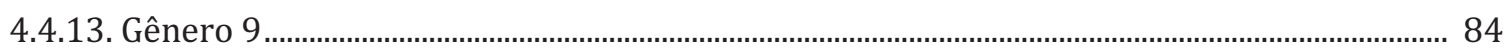

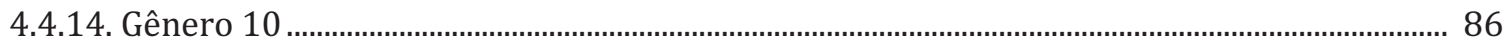

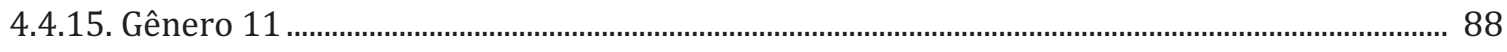

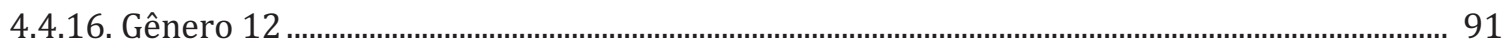

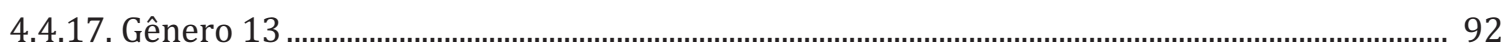

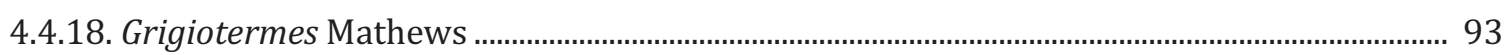

4.4.19. Humutermes Bourguignon e Roisin............................................................................................... 95

4.4.20. Hydrecotermes Bourguignon e Roisin ..............................................................................................97

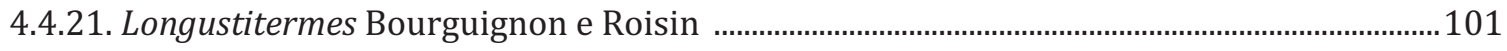

4.4.22. Patawatermes Bourguignon e Roisin .......................................................................................... 102

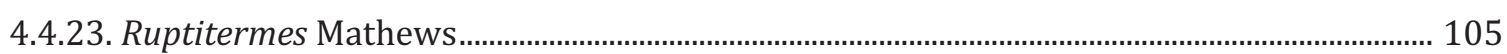

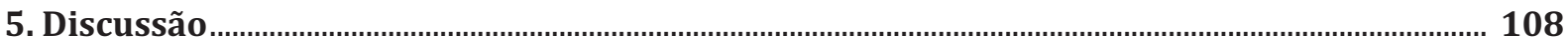

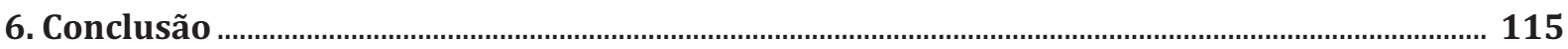

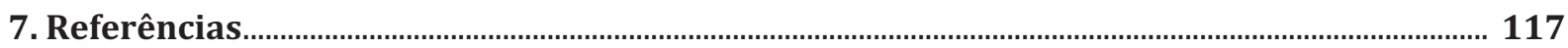

VOLUME II

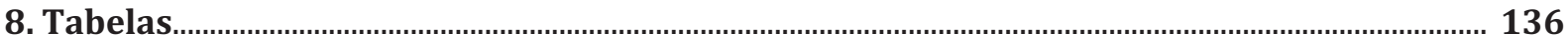

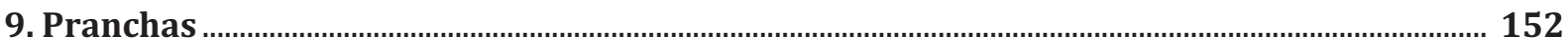



8. Tabelas 
Tabela 1. Total de amostras estudadas para o desenvolvimento deste trabalho. Ver acrônimos no texto.

\begin{tabular}{|c|c|}
\hline $\begin{array}{c}\text { AMNH } \\
\text { (visita à coleção) }\end{array}$ & $\begin{array}{l}\text { Anoplotermes bahamensis Scheffrahn \& Krecek em Scheffrahn et al., 2006: 477-479 (uma amostra não tipo identificada por Scheffrahn) } \\
\text { Anoplotermes bolivianus Snyder, 1926: } 46-47 \text { (uma amostra) } \\
\text { Anoplotermes brucei Snyder, 1955: } 300 \text { (duas amostras, parátipos) } \\
\text { Anoplotermes cingulatus abbreviatus Silvestri, 1901: } 8 \text { (uma amostra, síntipo) } \\
\text { Anoplotermes distans Snyder, 1926: 48-49 (uma amostra, síntipo) } \\
\text { Anoplotermes gracilis Snyder, 1922: 28-29 (duas amostras, uma delas síntipo) } \\
\text { Anoplotermes hondurensis Snyder, 1924: } 37-38 \text { (uma amostra, síntipo) } \\
\text { Anoplotermes inopinatus Scheffrahn \& Krecek em Scheffrahn et al., 2006: 479-480 (uma amostra não tipo identificada pelo Scheffrahn) } \\
\text { Anoplotermes meridianus Emerson, 1925: } 421 \text { (uma amostra, parátipo) } \\
\text { Anoplotermes punctatus Snyder, 1926: } 56 \text { (uma amostra, síntipo) } \\
\text { Anoplotermes pyriformis Snyder, 1934: } 96 \text { (uma amostra, síntipo) } \\
\text { Anoplotermes rotundus Snyder, 1926: 56-57 (uma amostra, síntipo) } \\
\text { Anoplotermes subterraneus Emerson, 1925: } 425-426 \text { (quatro amostras, holótipo e parátipos) } \\
\text { Anoplotermes tenebrosus (Hagen, 1858): 193-195, 243, 284 (uma amostra, alado seco reidratado) } \\
\text { Aparatermes cingulatus (Burmeister, 1839): 767-768 (uma amostra da localidade tipo identificada por Emerson) }\end{array}$ \\
\hline $\begin{array}{c}\text { CMNH } \\
\text { (empréstimo) }\end{array}$ & $\begin{array}{l}\text { Anoplotermes banksi Emerson, 1925: 423-424 (uma amostra, identificada por Emerson) } \\
\text { Aparatermes silvestrii Emerson, 1925: 421-423 (uma amostra, parátipo) }\end{array}$ \\
\hline $\begin{array}{c}\text { FTDL } \\
\text { (doação) }\end{array}$ & Disjunctitermes insularis Scheffrahn em Scheffrahn et al., 2017: 77 (oito amostras, parátipos) \\
\hline MZUSP (depositadas previamente + coletadas + tipos) & $\begin{array}{l}600 \text { amostras } \\
\text { Grigiotermes meteocus Mathews } 1977 \text { (holótipo) } \\
\text { Ruptitermes bandeirai Acioli e Constantino } 2015 \text { (holótipo) } \\
\text { Ruptitermes pitan Acioli \& Constantino 2015(parátipo) } \\
\text { Ruptitermes xantochiton Mathews } 1977 \text { (holótipo) } \\
\text { Tetimatermes oliveirae Fontes } 1986 \text { (holótipo) }\end{array}$ \\
\hline $\begin{array}{c}\text { RIB } \\
\text { (doação) }\end{array}$ & $\begin{array}{l}\text { Amplucrutermes inflatus Bourguignon \& Roisin em Bourguignon et al., 2016a:19 (parátipo) } \\
\text { Humutermes krishnai Bourguignon \& Roisin em Bourguignon et al., 2016a:22 (parátipo) } \\
\text { Humutermes noiroti Bourguignon \& Roisin em Bourguignon et al., 2016a:22 (parátipo) } \\
\text { Hydrecotermes arienesho Bourguignon \& Roisin em Bourguignon et al., 2016a:24 (parátipo) } \\
\text { Hydrecotermes kawaii Bourguignon \& Roisin em Bourguignon et al., 2016a:24 (parátipo) }\end{array}$ \\
\hline $\begin{array}{c}\text { USNM } \\
\text { (empréstimo ao AMNH) }\end{array}$ & $\begin{array}{l}\text { Anoplotermes bolivianus Snyder, 1926: 46-47 (uma amostra, parátipo em má condição) } \\
\text { Anoplotermes rotundus Snyder, 1926: 56-57 (uma amostra, parátipo) } \\
\text { Anoplotermes subterraneus Emerson, 1925: 425-426 (uma amostra, parátipo) }\end{array}$ \\
\hline Total & 643 amostras \\
\hline
\end{tabular}


Tabela 2. Lista dos caracteres morfológicos selecionados para este estudo. A: dente apical, M1+2: primeiro mais segundo dente marginal, M3: terceiro dente marginal, Prm: proeminência molar, M1: primeiro dente marginal, M2: segundo dente marginal, Plm: placa molar, MEV: Microscopia Eletrônica de Varredura.

\begin{tabular}{|c|c|c|}
\hline \multicolumn{3}{|c|}{ Morfologia Comparada } \\
\hline & Alado & Operário \\
\hline 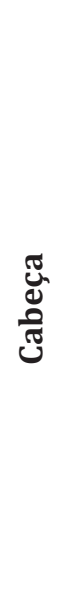 & $\begin{array}{l}\text {-Cabeça: forma/sutura/marcas/pilosidade } \\
\text {-Artículos da antena: número, pilosidade, } \\
\text { tamanho relativo. } \\
\text {-Fontanela: presença, ausência/ forma } \\
\text {-Olhos compostos: forma/ posição } \\
\text {-Ocelos: forma/posição } \\
\text {-Pós-clípeo: forma/margem/sutura mediana } \\
\text {-Labro: forma/margem/ pilosidade } \\
\text {-Mandíbula esquerda: forma e tamanho de A, } \\
\text { M1+2, M3, Prm, incisão } \\
\text {-Mandíbula direita: forma de A, M1, M2,Plm } \\
\text {-Maxila: forma e tamanho, gálea e lacínia } \\
\text {-Hipofaringe }\end{array}$ & $\begin{array}{l}\text {-Cabeça: forma/sutura/marcas/pilosidade } \\
\text {-Artículos da antena: número, pilosidade, } \\
\text { tamanho relativo } \\
\text {-Fontanela: presença, ausência/ forma } \\
\text {-Pós-clípeo: forma/margem/sutura mediana } \\
\text {-Labro: forma/margem/pilosidade } \\
\text {-Mandíbula esquerda: A, M1+2, M3, Prm, incisão } \\
\text {-Mandíbula direita: A, M1, M2, Plm } \\
\text {-Maxila: gálea e lacínia } \\
\text {-Hipofaringe }\end{array}$ \\
\hline 矛 & $\begin{array}{l}\text {-Pronoto: forma vista lateral, dorsal/ } \\
\text { margem/pilosidade } \\
\text {-Mesonoto e Metanoto: } \\
\text { forma/margem/pilosidade } \\
\text {-Escama alar } \\
\text {-Asa: venação/pilosidade/ornamentação } \\
\text {-Pernas: forma dos segmentos/ suturas/ } \\
\text { pilosidade/ esporões/ ornamentação (MEV) }\end{array}$ & $\begin{array}{l}\text {-Pronoto: forma vista lateral, dorsal/ } \\
\text { margem/pilosidade } \\
\text {-Mesonoto e Metanoto: } \\
\text { forma/margem/pilosidade } \\
\text {-Pernas: forma dos segmentos/ suturas/ } \\
\text { pilosidade/ esporões/ ornamentação (MEV) }\end{array}$ \\
\hline 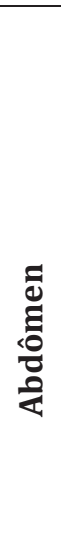 & $\begin{array}{l}\text {-Esternitos e tergitos: pilosidade } \\
\text {-Padrão de enrolamento dos segmentos do tubo } \\
\text { digestório } \\
\text {-Válvula entérica }\end{array}$ & $\begin{array}{l}\text {-Esternitos e tergitos: pilosidade } \\
\text {-Glândulas salivares: desenvolvimento } \\
\text {-Papo: desenvolvimento } \\
\text {-Moela: desenvolvimento/ ornamentação } \\
\text {-Mesêntero: forma/posição } \\
\text {-Segmento Misto: presença, ausência/ } \\
\text { ornamentação. } \\
\text {-Túbulos de Malpighi: inserção } \\
\text {-Íleo: forma/ orientação/ ornamentação interna } \\
\text {-Válvula entérica: ornamentação/simetria } \\
\text {-Pança: forma/enrolamento/posição } \\
\text {-Quarto e quinto segmento proctodeal: forma e } \\
\text { posição. }\end{array}$ \\
\hline
\end{tabular}


Tabela 3. Comparação entre os tipos de cerdas.

\begin{tabular}{|c|c|c|}
\hline \multirow{5}{*}{$\begin{array}{l}\text { Cerdas: são longas } \\
\text { e duras com bases } \\
\text { bem marcadas }\end{array}$} & $\begin{array}{l}\text { Espiniformes: tem uma base larga e é } \\
\text { bastante robusta e esclerotizada, a } \\
\text { articulação na cutícula é muito evidente, é } \\
\text { possível perceber as margens da região de } \\
\text { encaixe. }\end{array}$ & Fig. 223 - Gên. 10 sp. FonA \\
\hline & $\begin{array}{l}\text { Grossas: Em geral mais curtas que as } \\
\text { espiniformes e menos esclerotizadas. }\end{array}$ & Fig. 234 - Gên. 11sp. ES3 \\
\hline & $\begin{array}{l}\text { Longas: mais finas que as grossas e de igual } \\
\text { espessura das cerdas típicas e curtas, difere } \\
\text { no comprimento. }\end{array}$ & $\begin{array}{l}\text { Fig. } 156 \text { - Gên. } 3 \text { sp. ORQ } \\
\text { Fig. } 218 \text { - Gên. } 10 \text { sp. FonA } \\
\text { (cerdas longas e medianas) }\end{array}$ \\
\hline & $\begin{array}{l}\text { Medianas: comprimento médio; é a mais } \\
\text { comum. }\end{array}$ & $\begin{array}{l}\text { Fig. } 218 \text { - Gên. } 10 \text { sp. FonA } \\
\text { (cerdas longas e medianas) }\end{array}$ \\
\hline & Curtas: menores que as anteriores. & $\begin{array}{l}\text { Fig. } 83 \text { - Aparatermes } \\
\text { abbreviatus, (seta) }\end{array}$ \\
\hline \multirow{2}{*}{$\begin{array}{l}\text { Pelos: são mais } \\
\text { curtos e mais finos } \\
\text { do que as cerdas e } \\
\text { não possuem } \\
\text { bases conspícuas }\end{array}$} & Longos & \\
\hline & Curtos & $\begin{array}{l}\text { Fig. } 48 \text { - Anoplotermes } \\
\text { pacificus }\end{array}$ \\
\hline
\end{tabular}


Tabela 4. Lista dos caracteres morfométricos estudados. Os números entre parênteses indicam a correspondência com o sistema proposto por Roonwal (1970), as medidas referentes às mandíbulas seguem Sands (1972).

\begin{tabular}{|c|c|}
\hline \multicolumn{2}{|c|}{ Caracteres Morfométricos } \\
\hline Alados & Operários \\
\hline $\begin{array}{l}\text { Comprimento da cabeça até a base das } \\
\text { mandíbulas (5) }\end{array}$ & $\begin{array}{l}\text { Comprimento da cabeça até a base das } \\
\text { mandíbulas (5) }\end{array}$ \\
\hline Largura da cabeça com olhos (17) & Largura máx. da cabeça (17) \\
\hline $\begin{array}{l}\text { Diâmetro máximo do olho composto com } \\
\text { esclerito (48) }\end{array}$ & Largura do pronoto (68) \\
\hline Distância entre os olhos (52) & Comprimento da tíbia posterior (85) \\
\hline Diâmetro máximo do ocelo (55) & \\
\hline Diâmetro mínimo do ocelo (56) & \\
\hline Distância mínima entre olho e ocelo (57) & \\
\hline $\begin{array}{l}\text { Distância mínima entre olho e margem inferior } \\
\text { (novo) }\end{array}$ & \\
\hline Comprimento máximo do pronoto (65) & \\
\hline Largura do pronoto (68) & \\
\hline $\begin{array}{l}\text { Comprimento máximo da asa anterior sem } \\
\text { escama (74) }\end{array}$ & \\
\hline Comprimento máximo da escama alar (76) & \\
\hline Comprimento da tíbia anterior (85) & \\
\hline Largura da tíbia anterior (nova) & \\
\hline $\begin{array}{l}\text { Índice da tíbia anterior [largura/comprimento } \\
\text { (58)] }\end{array}$ & \\
\hline Comprimento da tíbia posterior (85) & \\
\hline $\begin{array}{l}\text { Ra: mandíbula direita, distância entre o dente } \\
\text { apical e o primeiro marginal. }\end{array}$ & $\begin{array}{l}\text { Ra: mandíbula direita, distância entre o dente } \\
\text { apical e o primeiro marginal. }\end{array}$ \\
\hline $\begin{array}{l}\text { R1: mandíbula direita, distância entre o } \\
\text { primeiro e o segundo dente marginal. }\end{array}$ & $\begin{array}{l}\text { R1: mandíbula direita, distância entre o } \\
\text { primeiro e o segundo dente marginal. }\end{array}$ \\
\hline $\begin{array}{l}\text { La: mandíbula esquerda, distância entre o } \\
\text { dente apical e o primeiro dente marginal }\end{array}$ & $\begin{array}{l}\text { La: mandíbula esquerda, distância entre o } \\
\text { dente apical e o primeiro dente marginal }\end{array}$ \\
\hline $\begin{array}{l}\text { L1: mandíbula esquerda, distância entre o } \\
\text { primeiro mais o segundo e o terceiro dente } \\
\text { marginal. }\end{array}$ & $\begin{array}{l}\text { L1: mandíbula esquerda, distância entre o } \\
\text { primeiro mais o segundo e o terceiro dente } \\
\text { marginal. }\end{array}$ \\
\hline
\end{tabular}


Tabela 5. Lista das espécies estudadas comparando o valor da largura da cabeça do operário (WH) e índice da tíbia anterior (largura/comprimento). As linhas em cinza indicam espécies novas.

\begin{tabular}{|c|c|c|}
\hline Espécies & WH do operário & Índice da tíbia \\
\hline Anoplotermes banksi & $0,56-0,68(0,62)$ & $0,22-0,29(0,24)$ \\
\hline Anoplotermes meridianus & $0,38-0,63(0,57)$ & $0,26-0,32(0,29)$ \\
\hline Anoplotermes pacificus & $0,54-0,68(0,62)$ & $0,23-0,33(0,29)$ \\
\hline Anoplotermes sp. 1 & $0,56-0,60(0,58)$ & $0,23-0,29(0,26)$ \\
\hline Anoplotermes sp. 2 & $0,54-0,58(0,56)$ & $0,24-0,30(0,28)$ \\
\hline Aparatermes abbreviatus & $0,96-1,16(1,06)$ & $0,16-0,25(0,20)$ \\
\hline Aparatermes cingulatus & $1,18-1,36(1,27)$ & $0,15-0,19(0,18)$ \\
\hline Compositermes vindai & $0,80-0,88(0,84)$ & $0,17-0,25(0,22)$ \\
\hline Disjunctitermes sp. 1 & $0,66-0,74(0,69)$ & $0,25-0,33(0,28)$ \\
\hline Disjunctitermes sp. 2 & $0,70-0,76(0,74)$ & $0,27-0,33(0,29)$ \\
\hline Gen. 1 sp. ES2 & $0,66-0,74(0,72)$ & $0,21-0,29(0,24)$ \\
\hline Gen. 1 sp. S5 & $0,80-0,88(0,83)$ & $0,18-0,23(0,21)$ \\
\hline Gen. 2 sp. MCH & $1,06-1,22(1,13)$ & $0,14-0,18(0,16)$ \\
\hline Gen. 3 sp. ORQ & $0,96-1,00(0,99)$ & $0,16-0,26(0,19)$ \\
\hline Gen. 4 sp. V1 & $0,88-0,94(0,91)$ & $0,15-0,24(0,19)$ \\
\hline Gen. 5 sp. V4 & $0,92-1,00(0,98)$ & $0,17-0,25(0,20)$ \\
\hline Gen. 6 sp. S8 & $0,80-1,12(0,99)$ & $0,17-0,26(0,22)$ \\
\hline Gen. 7 sp. S7 & $0,96-1,00(0,97)$ & $0,20-0,24(0,23)$ \\
\hline Gen. 8 sp. S3 & $0,98-1,12(1,04)$ & $0,19-0,26(0,22)$ \\
\hline Gen. 9 sp. V3 & $0,82-0,88(0,84)$ & $0,19-0,23(0,21)$ \\
\hline Gen. 10 sp. FonA & $0,96-1,24(1,13)$ & $0,18-0,25(0,22)$ \\
\hline Gen. 11 sp. ES3 & $0,88-0,98(0,93)$ & $0,16-0,19(0,17)$ \\
\hline Gen. 11 sp. V2 & $1,21-1,30(1,26)$ & $0,15-0,2(0,17)$ \\
\hline Gen. 12 sp. P1C & $0,85-1,02(0,94)$ & $0,20-0,28(0,23)$ \\
\hline Gen. 13 sp. S6 & $0,86-0,94(0,91)$ & $0,18-0,25(0,22)$ \\
\hline Grigiotermes hageni & $0,85-0,92(0,89)$ & $0,20-0,21(0,20)$ \\
\hline Grigiotermes sp. 1 & $0,93-1,08(1,04)$ & $0,14-0,21(0,18)$ \\
\hline Humutermes krishnai & $0,43-0,63(0,57)$ & $0,23-0,37(0,28)$ \\
\hline Hydrecotermes sp. 1 & $0,72-0,77(0,75)$ & $0,20-0,26(0,24)$ \\
\hline Longustitermes manni & $0,47-0,58(0,51)$ & $0,27-0,30(0,30)$ \\
\hline Patawatermes nigripunctatus & $0,70-0,77(0,72)$ & $0,27-0,32(0,30)$ \\
\hline Patawatermes turricola & $0,95-1,08(1,01)$ & $0,17-0,24(0,20)$ \\
\hline Ruptitermes bandeirai & $0,75-0,80(0,77)$ & $0,16-0,22(0,20)$ \\
\hline Ruptitermes pitan & $1,58-1,60(1,58)$ & $0,10-0,12(0,11)$ \\
\hline Ruptitermes reconditus & $0,95-1,18(1,08)$ & $0,13-0,21(0,16)$ \\
\hline
\end{tabular}


Tabela 6. Características-chave e sua distribuição entre os alados das espécies de Apicotermitinae neotropical.

\begin{tabular}{|l|l|}
\hline \multicolumn{1}{|c|}{ CARACTERÍSTICAS } & \multicolumn{1}{c|}{ ALADOS } \\
\hline $\begin{array}{l}\text { A. Fontanela com diferença na forma entre } \\
\text { machos e fêmeas }\end{array}$ & Anoplotermes subterraneus, Gên. 2 sp. MCH e Patawatermes turricola \\
\hline $\begin{array}{l}\text { B. Processo pré-molar visível (mandíbula } \\
\text { esquerda) }\end{array}$ & $\begin{array}{l}\text { Anoplotermes banksi, Anoplotermes meridianus, Anoplotermes pacificus, Anoplotermes sp. 1, } \\
\text { Disjunctitermes sp. 1, Disjunctitermes sp. 2, Gên. 4 sp. V1, Longustitermes manni, Patawatermes } \\
\text { turricola, Ruptitermes pitan }\end{array}$ \\
\hline $\begin{array}{l}\text { C. Processo molar visível (mandíbula esquerda) } \\
\text { D. Tíbia anterior com duas fileiras de cerdas } \\
\text { grossas }\end{array}$ & $\begin{array}{l}\text { Disjunctitermes sp. 1, Disjunctitermes sp. 2, Patawatermes turricola, Gên. 8 sp. S3, Gên. 9 sp. V3, Gên. } \\
\text { spen. 10 sp. FonB }\end{array}$ \\
\hline
\end{tabular}

Tabela 7. Características-chave e sua distribuição entre os operários das espécies de Apicotermitinae neotropical.

\begin{tabular}{|c|c|}
\hline CARACTERÍSTICAS & OPERÁRIOS \\
\hline A. Processo molar visível (mandíbula esquerda) & $\begin{array}{l}\text { Compositermes vindai, Anoplotermes bahamensis, Anoplotermes subterraneus, Patawatermes } \\
\text { turricola, Amplucrutermes inflatus, Gên. } 3 \text { sp. ORQ Gên. } 7 \text { sp. S7, Gên. } 11 \text { sp. ES3, Gên. } 12 \text { sp. P1C, } \\
\text { Patawatermes nigripunctatus, Gên. } 8 \text { sp. S3 }\end{array}$ \\
\hline B. Processo molar semioculto ou variável & $\begin{array}{l}\text { Hydrecotermes arienesho, Hydrecotermes kawaii, Disjunctitermes sp. 1, Disjunctitermes sp. 2, } \\
\text { Compositermes bani, Disjunctitermes insularis, Gên. } 10 \text { sp. FonA, Gên. } 10 \text { sp. FonB, Grigiotermes } \\
\text { hageni, Grigiotermes sp. } 1\end{array}$ \\
\hline C. Coxas anteriores com cerdas grossas & $\begin{array}{l}\text { Gên. } 8 \text { sp. S3, Gên. } 10 \text { sp. FonA, Gên. } 10 \text { sp. FonB, Rubeotermes jheringi, e Ruptitermes (exceto } \\
\text { Ruptitermes arboreus e Ruptitermes bandeirai) }\end{array}$ \\
\hline $\begin{array}{l}\text { D. Tíbia anterior com duas fileiras de cerdas } \\
\text { grossas }\end{array}$ & Aparatermes silvestrii, Gên. 8 sp. S3, Gên. 10, Gên. 11 sp. ES3, Gên. 11 sp. V2 \\
\hline $\begin{array}{l}\text { E. Órgãos deiscentes visíveis no animal fixado } \\
\text { em álcool }\end{array}$ & $\begin{array}{l}\text { Gên. } 1 \text { sp. ES2, Gên. } 1 \text { sp. S5, Gên. } 5 \text { sp. V4, Gên. } 7 \text { sp. S7, Gên. } 11 \text { sp. V2, Gên. } 9 \text { sp. V3, Patawatermes } \\
\text { turricola e Ruptitermes spp. }\end{array}$ \\
\hline $\begin{array}{l}\text { F. Órgãos deiscentes visíveis apenas no animal } \\
\text { vivo (ou fixação especial) }\end{array}$ & Gên. 2 sp. MCH, Aparatermes abbreviatus \\
\hline G. Lingueta mesentérica longa não inflada & Disjunctitermes insularis, Disjunctitermes sp. 1, Disjunctitermes sp. 2, Gên. 9 sp. V3 \\
\hline H. Lingueta mesentérica longa inflada & $\begin{array}{l}\text { Anoplotermes banksi, Anoplotermes bahamensis, Anoplotermes inopinatus, Anoplotermes janus, } \\
\text { Anoplotermes meridianus, Anoplotermes pacificus, Anoplotermes parvus; Anoplotermes sp. 1, } \\
\text { Anoplotermes sp. 2, Gên. } 6 \text { sp. S8, Humutermes krishnai, Humutermes noiroti }\end{array}$ \\
\hline I. Lingueta mesentérica curta inflada & $\begin{array}{l}\text { Anoplotermes meridianus, Longustitermes manni, Patawatermes nigripunctatus, Patawatermes } \\
\text { turricola }\end{array}$ \\
\hline J. Íleo longo (termina dorsalmente) & $\begin{array}{l}\text { Anoplotermes; Anoplotermes meridianus, Aparatermes abbreviatus e Aparatermes cingulatus, } \\
\text { Compositermes, Disjunctitermes sp. 2, Gênero } 1 \text { e Gênero 5, }\end{array}$ \\
\hline K. Íleo curto (termina ventralmente) & Gênero 4, Gênero 10, e Gênero 12 \\
\hline L. Assentamento da VE trilobado & $\begin{array}{l}\text { Anoplotermes meridianus, nas espécies de Aparatermes, Disjunctitermes; Longustitermes; Gênero } 11 \\
\text { e Gênero 13; Ruptitermes pitan e Ruptitermes reconditus }\end{array}$ \\
\hline M. Válvula entérica fracamente armada & $\begin{array}{l}\text { Amplucrutermes inflatus, Anoplotermes janus, Anoplotermes sp. 2, Gên. } 5 \text { sp. V4, Longustitermes } \\
\text { manni, Rubeotermes jheringi, Ruptitermes bandeirai e Tetimatermes oliveirae. }\end{array}$ \\
\hline N. Válvula entérica fortemente armada & $\begin{array}{l}\text { Anoplotermes parvus, Echinotermes biriba, Gên. } 2 \text { sp. MCH, Gên. } 3 \text { sp. ORQ, Gên. } 12 \text { sp. P1C, } \\
\text { Grigiotermes hageni, Grigiotermes sp. 1, Humutermes noiroti, Humutermes krishnai, Patawatermes } \\
\text { nigripunctatus e Patawatermes turricola }\end{array}$ \\
\hline O. Válvula entérica inerme & $\begin{array}{l}\text { Anoplotermes bahamensis, Anoplotermes banksi, Anoplotermes inopinatus } \\
\text { Anoplotermes meridianus, Anoplotermes pacificus, Anoplotermes punctatus, Anoplotermes sp. 1, } \\
\text { Anoplotermes subterraneus, Aparatermes abbreviatus, Aparatermes cingulatus, Aparatermes } \\
\text { silvestrii, Compositermes vindai, Disjunctitermes insularis } \\
\text { Disjunctitermes sp. 1, Disjunctitermes sp. } 2 \text {, Gên. nov. } 1 \text { sp. nov. S5, Gên. } 1 \text { sp. ES2, Gên. } 4 \text { sp. V1, Gên. } \\
6 \text { sp. S8, Gên. } 7 \text { sp. S7, Gên. } 8 \text { sp. S3, Gên. } 9 \text { sp. V3, Gên. } 10 \text { sp. FonA, Gên. } 10 \text { sp. FonB, Gên. } 11 \text { sp. } \\
\text { ES3, Gên. } 11 \text { sp. V2, Gên. } 13 \text { sp. S6, Hydrecotermes arienesho, Hydrecotermes kawaii, Hydrecotermes } \\
\text { sp. 1, Ruptitermes pitan, Ruptitermes reconditus }\end{array}$ \\
\hline
\end{tabular}


Tabela 8. Medidas dos alados de Anoplotermes e Humutermes; mínimo-máximo (média), em milímetros.

\begin{tabular}{|c|c|c|c|c|c|c|c|c|c|c|}
\hline \multirow[t]{2}{*}{ Medidas } & \multirow{2}{*}{$\begin{array}{c}\text { A. bahamensis } \\
\text { Scheffrahn et al. } 2006 \\
-\end{array}$} & \multicolumn{2}{|c|}{ A. banksi } & \multirow{2}{*}{\begin{tabular}{|c|} 
A. inopinatus \\
Scheffrahn et al. 2006 \\
-
\end{tabular}} & \multicolumn{2}{|c|}{ A. pacificus } & \multicolumn{2}{|c|}{ Anoplotermes. sp. 1} & \multicolumn{2}{|c|}{$\begin{array}{c}\text { H. krishnai } \\
\text { Bourguignon et al. 2016a }\end{array}$} \\
\hline & & $q \mathrm{n}=1$ & $n=2$ & & o $\mathrm{n}=5$ & $\delta n=5$ & q $\mathrm{n}=6$ & $n=4$ & 우 & $\hat{0}$ \\
\hline Comprimento da cabeça até a base da mandíbula & 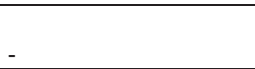 & 0,60 & \begin{tabular}{|l|}
$0,54-0,58$ \\
$(0,56)$
\end{tabular} & - & $\begin{array}{l}0,46-0,54 \\
(0,50)\end{array}$ & $\begin{array}{l}0,40-0,50 \\
(0,46)\end{array}$ & $\begin{array}{l}0,46-0,58 \\
(0,52)\end{array}$ & \begin{tabular}{|l|}
$0,44-0,48$ \\
$(0,46)$
\end{tabular} & & \\
\hline Largura da cabeça com olhos & $\begin{array}{l}1,16-1,21 \\
(1,19) \\
\end{array}$ & 0,78 & 0,76 & \begin{tabular}{|l|}
$0,98-1,03$ \\
$(1,01)$
\end{tabular} & $\begin{array}{l}0,60-0,78 \\
(0,70)\end{array}$ & $\begin{array}{l}0,42-0,56 \\
(0,67)\end{array}$ & $\begin{array}{l}0,64-0,68 \\
(0,67)\end{array}$ & $\begin{array}{l}0,64-0,66 \\
(0,65)\end{array}$ & $0,694-0,748$ & $0,682-0,746$ \\
\hline Distância entre os olhos & - & 0,60 & 0,60 & - & $\begin{array}{l}0,44-0,58 \\
(0,52)\end{array}$ & $\begin{array}{l}0,42-0,56 \\
(0,50)\end{array}$ & $\begin{array}{l}0,50-0,52 \\
(0,51)\end{array}$ & 0,50 & - & - \\
\hline $\begin{array}{l}\text { Diâmetro máximo do olho composto com } \\
\text { esclerito }\end{array}$ & $\begin{array}{l}0,28-0,30 \\
(0,29)\end{array}$ & 0,24 & 0,22 & \begin{tabular}{|l|}
$0,24-028$ \\
$(0,26)$
\end{tabular} & $\begin{array}{l}0,20-0,22 \\
(0,21)\end{array}$ & $\begin{array}{l}0,18-0,20 \\
(0,19)\end{array}$ & $\begin{array}{l}0,20-0,22 \\
(0,22)\end{array}$ & 0,22 & $0,186-0,216$ & $0,176-0,211$ \\
\hline Diâmetro máximo do ocelo & $\begin{array}{l}0,11-0,14 \\
(0,12)\end{array}$ & 0,10 & 0,10 & $\begin{array}{l}0,10-0,11 \\
(0,11)\end{array}$ & 0,08 & $\begin{array}{l}0,08-0,10 \\
(0,08)\end{array}$ & 0,08 & 0,08 & - & - \\
\hline Diâmetro mínimo do ocelo & 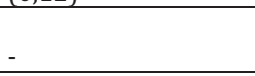 & 0,08 & 0,08 & - & $\begin{array}{l}0,06-0,07 \\
(0,06)\end{array}$ & $\begin{array}{l}0,06-0,08 \\
(0,06)\end{array}$ & $\begin{array}{l}0,06-0,07 \\
(0,06)\end{array}$ & 0,06 & - & - \\
\hline Distância mínima entre olho e ocelo & $\begin{array}{l}0,08-0,10 \\
(0,09)\end{array}$ & 0,03 & 0,03 & $\begin{array}{l}0,06-0,08 \\
(0,07)\end{array}$ & $\begin{array}{l}0,02-0,03 \\
(0,03)\end{array}$ & $\begin{array}{l}0,02-0,04 \\
(0,03)\end{array}$ & $\begin{array}{l}0,02-0,03 \\
(0,03)\end{array}$ & $\begin{array}{l}0,02-0,03 \\
(0,03)\end{array}$ & - & - \\
\hline Distância mínima entre olho e margem inferior & $\begin{array}{l}0,07-0,10 \\
(0,09)\end{array}$ & 0,05 & $\begin{array}{l}0,03-0,05 \\
(0,04)\end{array}$ & $\begin{array}{l}0,7-0,10 \\
(0,8)\end{array}$ & $\begin{array}{l}0,02-0,03 \\
(0,03)\end{array}$ & $\begin{array}{l}0,02-0,03 \\
(0,03)\end{array}$ & $\begin{array}{l}0,03-0,04 \\
(0,03)\end{array}$ & $\begin{array}{l}0,02-0,03 \\
(0,03)\end{array}$ & - & - \\
\hline Comprimento máximo do pronoto & $\begin{array}{l}0,62-0,69 \\
(0,66)\end{array}$ & 0,40 & $\begin{array}{l}0,36-0,40 \\
(0,38)\end{array}$ & $\begin{array}{l}0,51-0,56 \\
(0,53)\end{array}$ & $\begin{array}{l}0,32-0,38 \\
(0,35)\end{array}$ & $\begin{array}{l}0,30-0,38 \\
(0,35)\end{array}$ & $\begin{array}{l}0,28-0,34 \\
(0,32)\end{array}$ & $\begin{array}{l}0,26-0,32 \\
(0,30)\end{array}$ & $0,358-0,397$ & $0,343-0,387$ \\
\hline Largura do pronoto & $\begin{array}{l}0,98-1,10 \\
(1,04)\end{array}$ & 0,64 & $\begin{array}{l}0,62-0,66 \\
(0,64)\end{array}$ & $\begin{array}{l}0,83-0,92 \\
(0,87)\end{array}$ & $\begin{array}{l}0,48-0,64 \\
(0,56)\end{array}$ & $\begin{array}{l}0,46-0,62 \\
(0,55)\end{array}$ & $\begin{array}{l}0,50-0,56 \\
(0,53)\end{array}$ & $\begin{array}{l}0,46-0,52 \\
(0,50)\end{array}$ & $0,550-0,604$ & $0,520-0,577$ \\
\hline $\begin{array}{l}\text { Comprimento máximo da asa anterior sem } \\
\text { escama }\end{array}$ & $\begin{array}{l}10,51-12,37 \\
(11,37)\end{array}$ & - & 6,64 & $\begin{array}{l}8,65-10,51 \\
(9,60)\end{array}$ & $\begin{array}{l}5,19-7,84 \\
(7,04)\end{array}$ & $\begin{array}{l}6,40-6,96 \\
(6,59)\end{array}$ & $\begin{array}{l}5,76-5,84 \\
(5,81)\end{array}$ & $\begin{array}{l}4,96-5,52 \\
(5,20)\end{array}$ & - & - \\
\hline Comprimento máximo da escama alar & (12) & 0,46 & 0,41 & 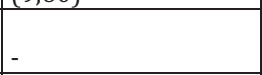 & $\begin{array}{l}0,32-0,47 \\
(0,38)\end{array}$ & $\begin{array}{l}0,30-0,46 \\
(0,39)\end{array}$ & $\begin{array}{l}0,25-0,33 \\
(0,31)\end{array}$ & $\begin{array}{l}0,28-0,32 \\
(0,30)\end{array}$ & - & - \\
\hline Comprimento da tíbia anterior & - & 0,66 & \begin{tabular}{|l|}
$0,61-0,66$ \\
$(0,64)$
\end{tabular} & - & $\begin{array}{l}0,43-0,60 \\
(0,49)\end{array}$ & $\begin{array}{l}0,42-0,64 \\
(0,51)\end{array}$ & $\begin{array}{l}0,45-0,48 \\
(0,46)\end{array}$ & $\begin{array}{l}0,45-0,48 \\
(0,47)\end{array}$ & - & - \\
\hline Largura da tíbia anterior & - & 0,10 & 0,10 & - & $\begin{array}{l}0,07-0,08 \\
(0,08)\end{array}$ & $\begin{array}{l}0,08-0,10 \\
(0,09)\end{array}$ & 0,08 & 0,08 & - & - \\
\hline Índice da tíbia anterior (largura/comprimento ) & - & 0,15 & $\begin{array}{l}0,15-0,16 \\
(0,16)\end{array}$ & - & $\begin{array}{l}0,11-0,19 \\
(0,17)\end{array}$ & $\begin{array}{l}0,16-0,20 \\
(0,17)\end{array}$ & $\begin{array}{l}0,17-0,19 \\
(0,18)\end{array}$ & $\begin{array}{l}0,16-0,19 \\
(0,17)\end{array}$ & - & - \\
\hline Comprimento da tíbia posterior & \begin{tabular}{|l|}
$1,19-1,24$ \\
$(1,21)$
\end{tabular} & 0,90 & 0,88 & \begin{tabular}{|l|}
$1,05-1,08$ \\
$(1,06)$
\end{tabular} & $\begin{array}{l}0,53-0,78 \\
(0,68)\end{array}$ & $\begin{array}{l}0,52-0,92 \\
(0,69)\end{array}$ & $\begin{array}{l}0,57-0,62 \\
(0,59)\end{array}$ & $\begin{array}{l}0,60-0,63 \\
(0,61)\end{array}$ & $0,591-0,697$ & $0,559-0,638$ \\
\hline 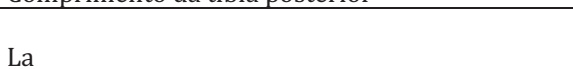 & 0,08 & 0,05 & - & $\begin{array}{l}0,08-0,09 \\
(0,08)\end{array}$ & 0,04 & (c) & 0,05 & (0) & ( & ( \\
\hline L1 & $\begin{array}{l}0,18-0,19 \\
(0,19)\end{array}$ & 0,11 & - & $\begin{array}{l}0,14-0,15 \\
(0,14)\end{array}$ & 0,15 & - & 0,12 & - & - & - \\
\hline $\mathrm{Ra}$ & $\begin{array}{l}0,09-0,10 \\
(0,10)\end{array}$ & 0,05 & - & $\begin{array}{l}0,08-0,09 \\
(0,08)\end{array}$ & 0,05 & - & 0,04 & - & - & - \\
\hline R1 & $\begin{array}{l}0,16-0,17 \\
(0,17)\end{array}$ & 0,10 & 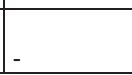 & $\begin{array}{l}0,10-0,11 \\
(0,10)\end{array}$ & 0,10 & - & 0,08 & - & - & - \\
\hline
\end{tabular}




\begin{tabular}{|c|c|c|c|c|c|c|c|}
\hline Medidas & \begin{tabular}{|c|} 
A. bahamensis \\
Scheffrahn et al. 2006 \\
\end{tabular} & A. banksi & \begin{tabular}{c|} 
A. inopinatus \\
Scheffrahn et al. 2006 \\
\end{tabular} & A. pacificus & Anoplotermes sp. 1 & Anoplotermes sp. 2 & H. krishnai \\
\hline & & $\mathrm{n}=10$ & & $\mathrm{n}=10$ & $\mathrm{n}=10$ & $n=10$ & $\mathrm{n}=10$ \\
\hline Comprimento da cabeça até a base da mandíbula & - & - & - & $0,44-0,56(0,51)$ & $0,42-0,54(0,49)$ & $0,44-0,54(0,47)$ & $0,43-0,55(0,50)$ \\
\hline Largura da cabeça & $0,85-0,90(0,87)$ & $0,56-0,68(0,62)$ & $0,78-0,85(0,81)$ & $0,54-0,68(0,62)$ & $0,56-0,60(0,58)$ & $0,54-0,58(0,56)$ & $0,43-0,63(0,57)$ \\
\hline Comprimento do lobo anterior do pronoto & - & $0,06-0,13(0,09)$ & & $0,08-0,12(0,10)$ & $0,08-0,12(0,10)$ & $0,07-0,10(0,09)$ & $0,08-0,12(0,11)$ \\
\hline Comprimento da tíbia anterior & $0,62-0,65(0,64)$ & $0,40-0,46(0,43)$ & $0,59-0,64(0,64)$ & $0,35-0,42(0,40)$ & $0,35-0,43(0,39)$ & $0,30-0,37(0,34)$ & $0,32-0,45(0,38)$ \\
\hline Largura da tíbia anterior & $0,14-0,15(0,14)$ & $0,10-0,12(0,10)$ & $0,13-0,15(0,14)$ & $0,10-0,12(0,11)$ & $0,08-0,12(0,10)$ & $0,08-0,10(0,09)$ & $0,08-0,12(0,11)$ \\
\hline Índice da tíbia (largura/comprimento) & - & $0,22-0,29(0,24)$ & - & $0,23-0,33(0,29)$ & $0,23-0,29(0,26)$ & $0,24-0,30(0,28)$ & $0,23-0,37(0,28)$ \\
\hline Comprimento da tíbia posterior & $0,77-0,80(0,79)$ & $0,47-0,58(0,53)$ & $0,72-0,75(0,74)$ & $0,38-0,55(0,47)$ & $0,42-0,50(0,45)$ & $0,37-0,42(0,39)$ & $0,37-0,53(0,47)$ \\
\hline La & $0,065-0,074(0,069)$ & 0,04 & $0,061-0,069(0,065)$ & 0,05 & 0,05 & 0,04 & 0,05 \\
\hline L1 & $0,15-0,16(0,16)$ & 0,12 & $0,11-0,12(0,12)$ & 0,12 & 0,12 & 0,08 & 0,1 \\
\hline $\mathrm{Ra}$ & $0,069-0,082(0,75)$ & 0,04 & $0,065-0,069(0,067)$ & 0,04 & 0,05 & 0,04 & 0,05 \\
\hline R1 & $0,11-0,12(0,11)$ & 0,08 & $0,078-0,090(0,083)$ & 0,08 & 0,08 & 0,07 & 0,08 \\
\hline
\end{tabular}

Tabela 10. Medidas dos alados de Anoplotermes brucei e Aparatermes; mínimo-máximo (média), em milímetros.

\begin{tabular}{|c|c|c|c|c|}
\hline Medidas & $\begin{array}{c}\text { Anoplotermes brucei } \\
\text { parátipo AMNH }\end{array}$ & $\begin{array}{c}\text { Aparatermes abbreviatus } \\
\text { síntipo AMNH }\end{array}$ & $\begin{array}{c}\text { Aparatermes cingulatus } \\
\text { amostra AMNH }\end{array}$ & $\begin{array}{c}\text { Aparatermes silvestrii } \\
\text { parátipo } \mathrm{CMNH}\end{array}$ \\
\hline & $\mathrm{n}=1$ & 을 & $q \mathrm{n}=1$ & $\mathrm{n}=1$ \\
\hline Comprimento da cabeça até a base da mandíbula & - & 1,04 & 1,22 & 1,14 \\
\hline Largura da cabeça com olhos & 1,39 & 1,38 & 1,75 & 1,50 \\
\hline Distância entre os olhos & 1,10 & 1,06 & 1,38 & 1,20 \\
\hline Diâmetro máximo do olho composto com esclerito & - & 0,30 & 0,36 & 0,34 \\
\hline Diâmetro máximo do ocelo & - & - & - & 0,12 \\
\hline Diâmetro mínimo do ocelo & - & - & - & 0,09 \\
\hline Distância mínima entre olho e ocelo & - & 0,07 & 0,14 & 0,15 \\
\hline Distância mínima entre olho e margem inferior & - & 0,10 & 0,12 & 0,10 \\
\hline Comprimento máximo do pronoto & - & - & - & 0,78 \\
\hline Largura do pronoto & - & 1,02 & 1,51 & 1,40 \\
\hline Comprimento máximo da asa anterior sem escama & - & - & - & - \\
\hline Comprimento máximo da escama alar & - & - & - & 0,73 \\
\hline Comprimento da tíbia anterior & - & - & - & 1,16 \\
\hline Largura da tíbia anterior & - & - & - & 0,16 \\
\hline Índice da tíbia anterior (largura/comprimento) & - & - & - & 0,14 \\
\hline Comprimento da tíbia posterior & - & 1,45 & 1,90 & 1,74 \\
\hline
\end{tabular}


Tabela 11. Medidas dos operários de Anoplotermes brucei, Aparatermes e Gênero 11; mínimo-máximo (média), em milímetros.

\begin{tabular}{|c|c|c|c|c|c|c|c|c|}
\hline Medidas & $\begin{array}{c}\text { An. brucei } \\
\text { parátipo AMNH }\end{array}$ & $\begin{array}{c}\text { Ap. abbreviatus } \\
\text { parátipo AMNH }\end{array}$ & Ap. abbreviatus & $\begin{array}{c}\text { Ap. cingulatus } \\
\text { topótipo AMNH }\end{array}$ & Ap. cingulatus & $\begin{array}{l}\text { Ap. silvestrii } \\
\text { parátipo CMNH }\end{array}$ & Gên. 11 sp. ES3 & Gên. 11 sp. V2 \\
\hline & & $\mathrm{n}=1$ & $\mathrm{n}=10$ & $\mathrm{n}=1$ & $\mathrm{n}=10$ & $\mathrm{n}=3$ & $\mathrm{n}=4$ & $\mathrm{n}=7$ \\
\hline Comprimento da cabeça até a base da mandíbula & 0,75 & 1,06 & $080-0,96(0,87)$ & 0,99 & $0,96-1,16(1,06)$ & $0,90-0,96(0,92)$ & $0,76-0,88(0,80)$ & $1,01-1,06(1,04)$ \\
\hline Largura da cabeça & 1,04 & 1,23 & $0,96-1,16(1,06)$ & 1,54 & $1,18-1,36(1,27)$ & $1,10-1,16(1,13)$ & $0,88-0,98(0,93)$ & $1,21-1,30(1,26)$ \\
\hline Comprimento do lobo anterior do pronoto & & - & $0,18-0,28(0,24)$ & - & $0,22-0,35(0,29$ & $0,25-0,28(026)$ & $0,15-0,22(0,19)$ & $0,20-0,30(0,25)$ \\
\hline Comprimento da tíbia anterior & & 0,76 & $0,67-0,78(0,73)$ & 0,99 & 0,83-1,08 $(0,94)$ & $0,88-0,92(0,90)$ & $0,70-0,75(0,72)$ & $0,83-0,90(0,85)$ \\
\hline Largura da tíbia anterior & & 0,18 & $0,12-0,18(0,15)$ & 0,19 & $0,15-0,18(0,17)$ & 0,13 & $0,120,13(0,13)$ & $0,13-0,16(0,14)$ \\
\hline Índice da tíbia (largura/comprimento) & & 0,24 & $0,16-0,25(0,20)$ & 0,19 & $0,15-0,19(0,18)$ & 0,15 & $0,16-0,19(0,17)$ & $0,15-0,20(0,17)$ \\
\hline Comprimento da tíbia posterior & & 1,10 & $0,85-1,00(0,92)$ & 1,31 & $1,03-1,37(1,20)$ & $1,17-1,25(1,19)$ & $0,88-0,92(0,90)$ & $1,05-1,11(1,07)$ \\
\hline $\mathrm{La}$ & & & 0,08 & & 0,10 & & 0,07 & 0,08 \\
\hline L1 & & & 0,16 & & 0,23 & & 0,17 & 0,22 \\
\hline $\mathrm{Ra}$ & & & 0,08 & & 0,08 & & 0,07 & 0,09 \\
\hline $\mathrm{R} 1$ & & & 0,12 & & 0,15 & & 0,15 & 0,17 \\
\hline
\end{tabular}

Tabela 12. Medidas dos alados de Anoplotermes subterraneus, Compositermes e Disjunctitermes; mínimo-máximo (média), em milímetros.

\begin{tabular}{|c|c|c|c|c|c|}
\hline \multirow[t]{2}{*}{ Medidas } & \multirow{2}{*}{\begin{tabular}{|c}
$\begin{array}{c}\text { Anoplotermes subterraneus } \\
\text { parátipo AMNH }\end{array}$ \\
$\ngtr \mathrm{n}=1$ \\
\end{tabular}} & \multirow{2}{*}{\begin{tabular}{|c|} 
Compositermes vindai \\
$\ngtr \mathrm{n}=1$ \\
\end{tabular}} & \multirow{2}{*}{\begin{tabular}{|c|} 
Disjunctitermes sp. 1 \\
$\bigcirc \mathrm{n}=1$ \\
\end{tabular}} & \multicolumn{2}{|c|}{ Disjunctitermes sp. 2} \\
\hline & & & & q $\mathrm{n}=5$ & $\mathrm{~s}=5$ \\
\hline Comprimento da cabeça até a base da mandíbula & 0,60 & 0,72 & 0,76 & $0,70-0,72(0,71)$ & $0,64-0,66(0,65)$ \\
\hline Largura da cabeça com olhos & 0,85 & 1,08 & 1,04 & $0,92-0,94(0,93)$ & $0,90-0,92(0,91)$ \\
\hline Distância entre os olhos & 0,64 & 0,82 & 0,78 & $0,70-0,72(0,71)$ & 0,70 \\
\hline Diâmetro máximo do olho composto com esclerito & 0,19 & 0,36 & 0,26 & $0,22-0,24(0,24)$ & 0,24 \\
\hline Diâmetro máximo do ocelo & 0,10 & 0,14 & 0,12 & $0,08-0,11(0,09)$ & $0,09-0,10(0,10)$ \\
\hline Diâmetro mínimo do ocelo & 0,07 & 0,10 & 0,09 & $0,08-0,10(0,08)$ & $0,07-0,08(0,08)$ \\
\hline Distância mínima entre olho e ocelo & 0,04 & 0,07 & 0,05 & 0,05 & $0,03-0,05(0,05)$ \\
\hline Distância mínima entre olho e margem inferior & 0,06 & 0,05 & 0,04 & $0,04-0,05(0,05)$ & $0,03-0,05(0,04)$ \\
\hline Comprimento máximo do pronoto & 0,45 & 0,54 & 0,66 & $0,46-0,48(0,47)$ & $0,44-0,46(0,46)$ \\
\hline Largura do pronoto & 0,70 & 0,90 & 1,08 & $0,64-0,72(0,69)$ & $0,46-0,68(0,59)$ \\
\hline Comprimento máximo da asa anterior sem escama & - & - & - & $10,53-10,13(10,29)$ & $9,33-9,87(9,60)$ \\
\hline Comprimento máximo da escama alar & - & - & 0,55 & $0,47-0,52(0,50)$ & $0,38-0,50(0,45)$ \\
\hline Comprimento da tíbia anterior & - & 0,77 & 0,48 & $0,67-0,68(0,67)$ & 0,67 \\
\hline Largura da tíbia anterior & - & 0,12 & 0,12 & 0,12 & $0,10-0,12(0,11)$ \\
\hline Índice da tíbia anterior (largura/comprimento) & - & 0,16 & 0,14 & $0,17-0,18(0,17)$ & $0,15-0,18(0,16)$ \\
\hline Comprimento da tíbia posterior & 0,81 & 1,05 & 1,00 & $0,83-0,95(0,91)$ & $0,88-0,92(0,90)$ \\
\hline $\mathrm{La}$ & - & - & 0,08 & 0,08 & \\
\hline L1 & - & - & 0,19 & 0,15 & \\
\hline $\mathrm{Ra}$ & - & - & 0,08 & 0,08 & \\
\hline R1 & - & - & 0,23 & 0,12 & \\
\hline
\end{tabular}


Tabela 13. Medidas dos operários de Anoplotermes subterraneus, Compositermes e Disjunctitermes; mínimo-máximo (média), em milímetros.

\begin{tabular}{|c|c|c|c|c|c|c|}
\hline Medidas & $\begin{array}{c}\text { Anoplotermes subterraneus } \\
\text { parátipo AMNH }\end{array}$ & $\begin{array}{c}\text { Compositermes bani } \\
\text { Carrijo et al. } 2015\end{array}$ & Compositermes vindai & $\begin{array}{c}\text { Disjunctitermes insularis } \\
\text { Scheffrahn et al. } 2017\end{array}$ & Disjunctitermes sp. 1 & Disjunctitermes sp. 2 \\
\hline & $\mathrm{n}=1$ & $n=5$ & $\mathrm{n}=10$ & $n=132$ & $\mathrm{n}=10$ & $\mathrm{n}=10$ \\
\hline Comprimento da cabeça até a base da mandíbula & 0,46 & $0,78-0,83$ & $0,68-0,78(0,71)$ & - & $0,52-0,66(0,58)$ & $0,60-0,64(0,62)$ \\
\hline Largura da cabeça & 0,58 & $0,88-0,93$ & $0,80-0,88(0,84)$ & $0,63-0,70$ & $0,66-0,74(0,69)$ & $0,70-0,76(0,74)$ \\
\hline Comprimento da tíbia anterior & 0,38 & - & $0,53-0,60(0,58)$ & - & $0,47-0,50(0,58)$ & $0,47-0,50(0,49)$ \\
\hline Largura da tíbia anterior & 0,11 & - & $0,10-0,15(0,13)$ & - & $0,47-0,50(0,49)$ & $0,13-0,17(0,14)$ \\
\hline Índice da tíbia (largura/comprimento) & 0,29 & - & $0,17-0,25(0,22)$ & $0,26-0,36$ & $0,25-0,33(0,28)$ & $0,27-0,33(0,29)$ \\
\hline Comprimento da tíbia posterior & 0,50 & $0,83-0,88$ & $0,60-0,75(0,69)$ & $0,46-0,56$ & $0,47-0,62(0,58)$ & $0,53-0,60(0,56)$ \\
\hline $\mathrm{La}$ & - & - & - & - & 0,05 & 0,07 \\
\hline L1 & - & - & - & - & 0,13 & 0,13 \\
\hline $\mathrm{Ra}$ & - & - & - & - & 0,05 & 0,05 \\
\hline R1 & - & - & - & - & 0,10 & 0,11 \\
\hline
\end{tabular}

Tabela 14. Medidas dos alados de Gênero 2 e Gênero 4; mínimo-máximo (média), em milímetros.

\begin{tabular}{|c|c|c|c|c|}
\hline \multirow[t]{2}{*}{ Medidas } & \multicolumn{2}{|c|}{ Gên. 2 sp. MCH } & \multicolumn{2}{|c|}{ Gên. 4 sp. V1 } \\
\hline & $9 \mathrm{n}=5$ & $n=4$ & $9 \mathrm{n}=2$ & $d n=3$ \\
\hline Comprimento da cabeça até a base da mandíbula & $0,92-0,96(0,94)$ & $0,90-1,00(0,94)$ & 0,82 & $0,72-0,78(0,75)$ \\
\hline Largura da cabeça com olhos & $1,34-1,38(1,36)$ & $1,26-1,28(1,28)$ & 1,14 & $1,04-1,07(1,06)$ \\
\hline Distância entre os olhos & $1,04-1,08(1,06)$ & $0,96-1,00(0,99)$ & $0,86-0,88(0,87)$ & $0,78-0,80(0,79)$ \\
\hline Diâmetro máximo do olho composto com esclerito & 0,30 & $0,28-0,30(0,29)$ & $0,28-0,30(0,29)$ & $0,26-0,29(0,27)$ \\
\hline Diâmetro máximo do ocelo & $0,12-0,16(0,14)$ & $0,12-0,14(0,13)$ & 0,14 & $0,12-0,14(0,13)$ \\
\hline Diâmetro mínimo do ocelo & $0,11-0,14(0,12)$ & 0,11 & 0,10 & $0,08-0,09(0,09)$ \\
\hline Distância mínima entre olho e ocelo & $0,10-0,15(0,12)$ & $0,08-0,12(0,10)$ & $0,07-0,08(0,08)$ & 0,07 \\
\hline Distância mínima entre olho e margem inferior & $0,08-0,12(0,10)$ & $0,07-0,10(0,08)$ & $0,05-0,06(0,05)$ & $0,03-0,05(0,04)$ \\
\hline Comprimento máximo do pronoto & $0,70-0,72(0,71)$ & $0,64-0,68(0,66)$ & 0,58 & $0,48-0,52(0,49)$ \\
\hline Largura do pronoto & $1,22-1,28(1,25)$ & $1,14-1,22(1,18)$ & $1,00-1,02(1,01)$ & $0,86-0,92(0,90)$ \\
\hline Comprimento máximo da asa anterior sem escama & $12,27-12,40(12,33)$ & $11,07-11,20(11,16)$ & 11,33 & $9,07-9,12(9,13)$ \\
\hline Comprimento máximo da escama alar & $0,58-0,73(0,69)$ & $0,67-0,70(0,68)$ & $0,60-0,65(0,63)$ & $0,42-0,55(0,51)$ \\
\hline Comprimento da tíbia anterior & $1,03-1,17(1,09)$ & $1,03-1,08(1,05)$ & $0,83-0,85(0,84)$ & $0,78-0,83(0,81)$ \\
\hline Largura da tíbia anterior & $0,12-0,15(0,14)$ & 0,13 & $0,10-0,12(0,11)$ & 0,1 \\
\hline Índice da tíbia anterior (largura/comprimento) & $0,10-0,14(0,13)$ & $0,12-0,13(0,12)$ & $0,12-0,14(0,13)$ & $0,12-0,13(0,12)$ \\
\hline Comprimento da tíbia posterior & $1,50-1,58(1,53)$ & $1,48-1,50(1,50)$ & $1,17-1,18(1,18)$ & $0,83-1,13(1,02)$ \\
\hline La & 0,10 & - & - & - \\
\hline L1 & 0,18 & - & - & - \\
\hline $\mathrm{Ra}$ & 0,08 & - & - & - \\
\hline R1 & 0,12 & - & - & - \\
\hline
\end{tabular}


Tabela 15. Medidas dos operários de Gênero 1, Gênero 2, Gênero 3 e Gênero 4; mínimo-máximo (média), em milímetros.

\begin{tabular}{|l|l|l|l|l|l|}
\hline \multicolumn{1}{|c|}{ Medidas } & Gên. 1 sp. ES2 & Gên. 1 sp. S5 & Gên. 2 sp. MCH & Gên. 3 sp. ORQ & Gên. 4 sp. V1 \\
\hline & \multicolumn{1}{|c|}{$\mathrm{n}=10$} & $\mathrm{n}=3$ & $\mathrm{n}=20$ & $\mathrm{n}=10$ & $\mathrm{n}=10$ \\
\hline Comprimento da cabeça até a base da mandíbula & $0,60-0,64(0,62)$ & $0,70-0,76(0,72)$ & $0,88-1,06(0,95)$ & $0,76-0,82(0,81)$ & $0,72-0,80(0,76)$ \\
\hline Largura da cabeça & $0,66-0,74(0,72)$ & $0,80-0,88(0,83)$ & $1,06-1,22(1,13)$ & $0,96-1,00(0,99)$ & $0,88-0,94(0,91)$ \\
\hline Comprimento da tíbia anterior & $0,47-0,60(0,53)$ & $0,50-0,57(0,54)$ & $0,92-1,05(0,98)$ & $0,78-0,85(0,82)$ & $0,58-0,68(0,64)$ \\
\hline Largura da tíbia anterior & $0,10-0,15(0,13)$ & $0,10-0,11(0,11)$ & $0,13-0,17(0,15)$ & $0,13-0,20(0,16)$ & $0,10-0,15(0,12)$ \\
\hline Índice da tíbia (largura/comprimento) & $0,21-0,29(0,24)$ & $0,18-0,23(0,21)$ & $0,14-0,18(0,16)$ & $0,16-0,26(0,19)$ & $0,15-0,24(0,19)$ \\
\hline Comprimento da tíbia posterior & $0,55-0,68(0,60)$ & $0,72-0,75(0,73)$ & $1,27-1,42(1,32)$ & $0,98-1,10(1,04)$ & $0,63-0,80(0,75)$ \\
\hline La & 0,05 & & 0,09 & 0,10 & 0,05 \\
\hline L1 & 0,13 & & 0,18 & 0,14 & 0,07 \\
\hline Ra & 0,05 & & 0,08 & 0,08 & 0,05 \\
\hline R1 & 0,10 & & 0,12 & 0,12 & 0,10 \\
\hline
\end{tabular}

Tabela 16. Medidas dos operários de Gênero 5, Gênero 6, Gênero 7 e Gênero 13; mínimo-máximo (média), em milímetros.

\begin{tabular}{|l|c|c|c|c|}
\hline \multicolumn{1}{|c|}{ Medidas } & & & & \\
& Gên. 5 sp. V4 & Gên. 6 sp. S8 & Gên. 7 sp. S7 & Gên. 13 sp. S6 \\
\hline Comprimento da cabeça até a base da mandíbula & $0,74-0,86(0,80)$ & $0,70-0,88(0,80)$ & $0,72-0,84(0,79)$ & $0,72-0,74(0,74)$ \\
\hline Largura da cabeça & $0,92-1,00(0,98)$ & $0,80-1,12(0,99)$ & $0,96-1,00(0,97)$ & $0,86-0,94(0,91)$ \\
\hline Comprimento da tíbia anterior & $0,67-0,73(0,68)$ & $0,58-0,83(0,71)$ & $0,62-0,70(0,66)$ & $0,65-0,73(0,69)$ \\
\hline Largura da tíbia anterior & $0,12-0,17(0,14)$ & $0,12-0,18(0,15)$ & $0,13-0,17(0,15)$ & $0,12-0,17(0,15)$ \\
\hline Índice da tíbia (largura/comprimento) & $0,17-0,25(0,20)$ & $0,17-0,26(0,22)$ & $0,20-0,24(0,23)$ & $0,18-0,25(0,22)$ \\
\hline Comprimento da tíbia posterior & $0,82-0,92(0,86)$ & $0,78-1,00(0,97)$ & $0,75-0,88(0,81)$ & $0,77-0,93(0,89)$ \\
\hline La & 0,09 & & 0,07 & 0,10 \\
\hline L1 & 0,16 & & 0,15 & 0,14 \\
\hline Ra & 0,08 & & 0,07 & 0,07 \\
\hline R1 & 0,11 & & 0,11 & 0,10 \\
\hline & & & & \\
\hline
\end{tabular}


Tabela 17. Medidas dos alados de Gênero 8, Gênero 9 e Gênero 10; mínimo-máximo (média), em milímetros.

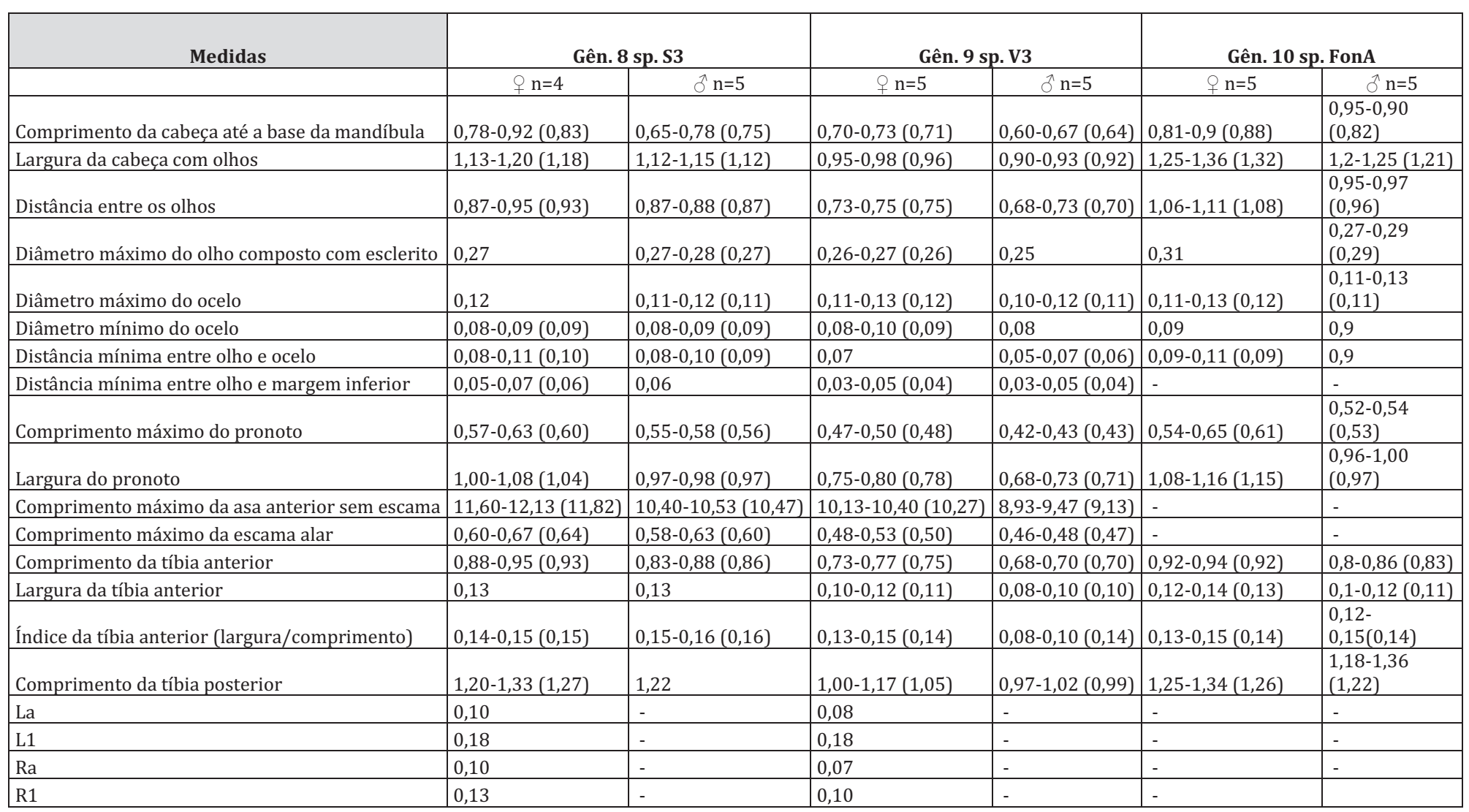




\begin{tabular}{|l|l|l|l|l|l|}
\hline \multicolumn{1}{|c|}{ Medidas } & Gên. 8 sp. S3 & Gên. 9 sp. V3 & Gên. 10 sp. FonA (op1) & Gên. 10 sp. FonA (op2) & Gên. 10 sp. FonB \\
\hline & \multicolumn{1}{|c|}{$\mathrm{n}=10$} & $\mathrm{n}=10$ & $\mathrm{n}=57$ & $\mathrm{n}=49$ & $\mathrm{n}=38$ \\
\hline Comprimento da cabeça até a base da mandíbula & $0,80-0,84(0,83)$ & $0,63-0,73(0,71)$ & $0,79-1,12(0,92)$ & $0,72-0,96(0,86)$ & $0,84-1,08(0,98)$ \\
\hline Largura da cabeça & $0,98-1,12(1,04)$ & $0,82-0,88(0,84)$ & $0,96-1,24(1,13)$ & $0,96-1,20(1,09)$ & $1,05-1,34(1,25)$ \\
\hline Comprimento da tíbia anterior & $0,63-0,72(0,67)$ & $0,58-0,67(0,61)$ & $0,66-0,84(0,73)$ & $0,64-0,78(0,70)$ & $0,8-0,9(0,85)$ \\
\hline Largura da tíbia anterior & $0,13-0,18(0,15)$ & $0,12-0,15(0,13)$ & $0,14-0,18(0,15)$ & $0,13-0,18(0,15)$ & $0,14-0,18(0,16)$ \\
\hline Índice da tíbia (largura/comprimento) & $0,19-0,26(0,22)$ & $0,19-0,23(0,21)$ & $0,18-0,25(0,22)$ & $0,17-0,25(0,22)$ & $0,18-0,23(0,19)$ \\
\hline Comprimento da tíbia posterior & $0,77-0,88(0,84)$ & $0,73-0,80(0,74)$ & $0,84-1,10(0,97)$ & $0,81-1,08(0,96)$ & $1,03-1,32(1,15)$ \\
\hline La & 0,08 & 0,08 & - & - & - \\
\hline L1 & 0,13 & 0,15 & - & - & - \\
\hline Ra & 0,07 & 0,07 & - & - & - \\
\hline R1 & 0,10 & 0,10 & - & - & - \\
\hline
\end{tabular}

Tabela 19. Medidas dos alados de Longustitermes, Anoplotermes meridianus e Hydrecotermes; mínimo-máximo (média), em milímetros.

\begin{tabular}{|c|c|c|c|c|c|c|c|c|c|c|}
\hline \multirow[t]{2}{*}{ Medidas } & \multicolumn{2}{|c|}{\begin{tabular}{|c} 
L. manni \\
Bourguignon et al. 2010
\end{tabular}} & \multirow{2}{*}{\begin{tabular}{|c|}
$\begin{array}{c}\text { A.meridianus } \\
\text { parátipo AMNH }\end{array}$ \\
$\bigcirc \mathrm{n}=1$ \\
\end{tabular}} & \multicolumn{2}{|c|}{ A. meridianus } & \multirow{2}{*}{\begin{tabular}{|c}
$\begin{array}{c}\text { Hydrecotermes arienesho } \\
\text { Bourguignon et al. 2016a }\end{array}$ \\
i $\mathrm{n}=1$
\end{tabular}} & \multicolumn{2}{|c|}{$\begin{array}{l}\text { Hydrecotermes kawaii } \\
\text { Bourguignon et al. 2016a }\end{array}$} & \multicolumn{2}{|c|}{ Hydrecotermes sp. 1} \\
\hline & $q \mathrm{n}=6$ & $3 n=6$ & & 和 $=5$ & $\mathrm{O}^{n} \mathrm{n}=5$ & & $q \mathrm{n}=3$ & $\hat{n}=1$ & $\bigcirc \mathrm{n}=6$ & $\mathrm{o}^{n} \mathrm{n}=6$ \\
\hline Comprimento da cabeça até a base da mandíbula & - & - & 0,82 & 0,58 & $0,55-0,58(0,56)$ & - & - & - & $0,57-0,67(0,62)$ & $0,52-0,67(0,57)$ \\
\hline Largura da cabeça com olhos & $0,56-0,57$ & $0,54-0,58$ & 1,09 & $0,73-0,75(0,74)$ & $0,72-0,75(0,73)$ & 1,006 & $0,861-0,874$ & 0,839 & $0,83-0,98(0,90)$ & $0,82-0,92(0,84)$ \\
\hline Distância entre os olhos & - & - & 0,83 & 0,55 & $0,52-0,55(0,53)$ & - & - & - & $0,62-0,75(0,69)$ & $0,60-0,68(0,63)$ \\
\hline Diâmetro máximo do olho composto com esclerito & $0,15-0,19$ & $0,15-0,18$ & 0,25 & $0,22-0,23(0,22)$ & 0,22 & 0,218 & $0,211-0,221$ & 0,235 & $0,23-0,28(0,26)$ & $0,23-0,25(0,24)$ \\
\hline Diâmetro máximo do ocelo & - & - & 0,10 & 0,08 & $0,08-0,09(0,09)$ & - & - & - & $0,11-0,13(0,12)$ & $0,09-0,13(0,11)$ \\
\hline Diâmetro mínimo do ocelo & - & - & 0,07 & $0,05-0,07(0,06)$ & $0,05-0,07(0,06)$ & - & - & - & 0,08 & $0,07-0,08(0,07)$ \\
\hline Distância mínima entre olho e ocelo & - & - & 0,08 & 0,03 & 0,03 & - & - & & $0,02-0,06(0,04)$ & $0,03-0,07(0,04)$ \\
\hline Distância mínima entre olho e margem inferior & - & - & 0,05 & $0,03-0,04(0,03)$ & 0,03 & - & - & & $0,03-0,05(0,04)$ & $0,03-0,05(0,04)$ \\
\hline Comprimento máximo do pronoto & $0,31-0,34$ & $0,32-0,34$ & 0,59 & $0,42-0,47$ & $0,40-0,43(0,42)$ & 0,550 & $0,386-0,437$ & 0,41 & $0,39-0,53(0,47)$ & $0,40-0,48(0,42)$ \\
\hline Largura do pronoto & $0,45-0,48$ & $0,44-0,47$ & 0,93 & $0,63-0,67(0,65)$ & $0,62-0,63(0,63)$ & 0,800 & $0,621-0,694$ & 0,64 & $0,63-0,88(0,76)$ & $0,62-0,72(0,66)$ \\
\hline Comprimento máximo da asa anterior sem escama & - & - & - & $9,47-9,73(9,63)$ & $8,40-8,67(8,55)$ & - & - & - & $7,07-11,20(9,13)$ & $6,47-7,07(6,69)$ \\
\hline Comprimento máximo da escama alar & - & - & - & $0,45-0,48(0,47)$ & $0,45-0,47(0,45)$ & - & - & - & $0,42-0,55(0,48)$ & $0,40-0,45(0,42)$ \\
\hline Comprimento da tíbia anterior & - & - & - & $0,52-0,55(0,53)$ & $0,52-0,53(0,52)$ & - & - & - & $0,68-1,00(0,87)$ & $0,78-0,92(0,85)$ \\
\hline Largura da tíbia anterior & - & - & - & 0,08 & $0,07-0,08(0,08)$ & & - & - & $0,57-0,70(0,66)$ & $0,57-0,67(0,60)$ \\
\hline Índice da tíbia anterior (largura/comprimento) & - & - & - & $0,15-0,16(0,16)$ & $0,13-0,16(0,14)$ & - & - & - & $0,10-0,12(0,10)$ & $0,08-0,10(0,09)$ \\
\hline Comprimento da tíbia posterior & $0,49-0,53$ & $0,47-0,54$ & 0,99 & $0,68-0,73(0,71)$ & $0,70-0,73(0,72)$ & 0,972 & $0,584-0,780$ & 0,783 & $0,14-0,18(0,16)$ & $0,14-0,17(0,15)$ \\
\hline Laa & - & - & - & 0,07 & - & - & - & - & - & - \\
\hline L1a & - & - & - & 0,12 & - & - & - & - & - & - \\
\hline Raa & - & - & - & 0,07 & - & - & - & - & - & - \\
\hline R1a & - & - & - & 0,08 & - & & - & - & - & - \\
\hline
\end{tabular}


Tabela 20. Medidas dos operários de Longustitermes, Anoplotermes distans, Anoplotermes meridianus e Hydrecotermes; mínimo-máximo (média), em milímetros.

\begin{tabular}{|c|c|c|c|c|c|c|c|}
\hline Medidas & L. manni & $\begin{array}{c}\text { Anoplotermes distans } \\
\text { síntipo AMNH }\end{array}$ & $\begin{array}{l}\text { A. meridianus } \\
\text { parátipo AMNH }\end{array}$ & A. meridianus & $\begin{array}{c}\text { Hydrecotermes arienesho } \\
\text { Bourguignon et al. 2016a }\end{array}$ & \begin{tabular}{|} 
Hydrecotermes kawaii \\
Bourguignon et al. 2016a
\end{tabular} & Hydrecotermes sp. 1 \\
\hline & $\mathrm{n}=10$ & $\mathrm{n}=1$ & $\mathrm{n}=1$ & $\mathrm{n}=10$ & $\mathrm{n}=12$ & $\mathrm{n}=12$ & $\mathrm{n}=10$ \\
\hline Comprimento da cabeça até a base da mandíbula & $0,45-0,50(0,46)$ & 0,47 & 0,67 & $0,43-0,52(0,50)$ & - & - & $0,55-0,65(0,59)$ \\
\hline Largura da cabeça & $0,47-0,58(0,51)$ & 0,65 & 0,77 & $0,38-0,63(0,57)$ & $0,685-0,778$ & $0,626-0,736$ & $0,72-0,77(0,75)$ \\
\hline Comprimento da tíbia anterior & $0,32-0,37(0,35)$ & 0,42 & 0,47 & $0,33-0,45(0,38)$ & - & - & $0,42-0,60(0,51)$ \\
\hline Largura da tíbia anterior (nova) & $0,10-0,12(0,10)$ & 0,11 & 0,13 & $0,10-0,13(0,11)$ & - & - & $0,08-0,13(0,13)$ \\
\hline Índice da tíbia (largura/comprimento) & $0,27-0,30(0,30)$ & 0,26 & 0,27 & $0,26-0,32(0,29)$ & $0,253-0,364$ & $0,270-0,386$ & $0,20-0,26(0,24)$ \\
\hline Comprimento da tíbia posterior & $0,37-0,42(0,39)$ & 0,51 & 0,57 & $0,38-0,50(0,44)$ & $0,415-0,550$ & $0,270-0,386$ & $0,57-0,68(0,64)$ \\
\hline $\mathrm{La}$ & 0,05 & - & - & 0,05 & - & - & - \\
\hline L1 & 0,08 & - & - & 0,10 & - & - & - \\
\hline Ra & 0,05 & - & - & 0,05 & - & - & - \\
\hline R1 & 0,07 & - & - & 0,08 & - & - & - \\
\hline
\end{tabular}

Tabela 21. Medidas dos operários de Gênero 12, Grigiotermes e Patawatermes; mínimo-máximo (média), em milímetros.

\begin{tabular}{|l|l|l|l|l|l|}
\hline \multicolumn{1}{|c|}{ Medidas } & Gênero 12 sp. P1C & Grigiotermes hageni & Grigiotermes sp. 1 & Patawatermes nigripunctatus & Patawatermes turricola \\
\hline & \multicolumn{1}{|c|}{$\mathrm{n}=10$} & \multicolumn{1}{|c|}{$\mathrm{n}=3$} & $\mathrm{n}=10$ & \multicolumn{1}{c|}{$\mathrm{n}=10$} & $\mathrm{n}=10$ \\
\hline Comprimento da cabeça até a base da mandíbula & $0,67-0,85(0,76)$ & $0,72-0,73(0,73)$ & $0,72-0,90(0,82)$ & $0,53-0,65(0,59)$ & $0,678-0,87(0,77)$ \\
\hline Largura da cabeça & $0,85-1,02(0,94)$ & $0,85-0,92(0,89)$ & $0,93-1,08(1,04)$ & $0,70-0,77(0,72)$ & $0,95-1,08(1,01)$ \\
\hline Comprimento da tíbia anterior & $0,53-0,83(0,73)$ & $0,65-0,68(0,67)$ & $0,73-0,87(0,80)$ & $0,53-0,60(0,57)$ & $0,60-0,72(0,65)$ \\
\hline Largura da tíbia anterior & $0,13-0,18(0,17)$ & 0,13 & $0,12-0,18(0,15)$ & $0,15-0,20(0,17)$ & $0,10-0,15(0,13)$ \\
\hline Índice da tíbia (largura/comprimento) & $0,20-0,28(0,23)$ & $0,20-0,21(0,20)$ & $0,14-0,21(0,18)$ & $0,27-0,32(0,30)$ & $0,17-0,24(0,20)$ \\
\hline Comprimento da tíbia posterior & $0,80-1,08(0,95)$ & $0,87-0,92(0,89)$ & $0,92-1,18(1,06)$ & $0,63-0,72(0,66)$ & $0,87-0,97(0,90)$ \\
\hline La & 0,1 & 0,09 & 0,10 & 0,06 & 0,10 \\
\hline L1 & 0,15 & 0,13 & 0,16 & 0,17 \\
\hline Ra & 0,09 & 0,07 & 0,08 & 0,08 \\
\hline R1 & 0,12 & 0,11 & 0,13 & 0,05 \\
\hline
\end{tabular}


Tabela 22. Medidas dos operários de Ruptitermes; mínimo-máximo (média), em milímetros.

\begin{tabular}{|l|l|l|l|}
\hline \multicolumn{1}{|c|}{ Medidas } & Ruptitermes bandeirai & Ruptitermes pitan & Ruptitermes reconditus \\
\hline & \multicolumn{1}{|c|}{$\mathrm{n}=10$} & $\mathrm{n}=4$ & $\mathrm{n}=10$ \\
\hline Comprimento da cabeça até a base da mandíbula & $0,58-0,63(0,62)$ & $1,20-1,28(1,24)$ & $0,80-0,93(0,87)$ \\
\hline Largura da cabeça & $0,75-0,80(0,77)$ & $1,58-1,60(1,58)$ & $0,95-1,18(1,08)$ \\
\hline Comprimento da tíbia anterior & $0,52-0,57(0,54)$ & $1,03-1,08(1,06)$ & $0,68-0,85(0,76)$ \\
\hline Largura da tíbia anterior & $0,08-0,12(0,11)$ & $0,10-0,13(0,11)$ & $0,10-0,15(0,12)$ \\
\hline Índice da tíbia (largura/comprimento) & $0,16-0,22(0,20)$ & $0,10-0,12(0,11)$ & $0,13-0,21(0,16)$ \\
\hline Comprimento da tíbia posterior & $0,72-0,77(0,74)$ & $1,43-1,55(1,49)$ & $0,90-1,10(0,98)$ \\
\hline La & 0,05 & 0,06 & - \\
\hline L1 & 0,13 & 0,22 & - \\
\hline Ra & 0,06 & 0,10 & - \\
\hline R1 & 0,13 & 0,20 & - \\
\hline
\end{tabular}

Tabela 23. Medidas dos alados de Patawatermes turricola e Ruptitermes pitan; mínimo-máximo (média), em milímetros.

\begin{tabular}{|c|c|c|c|c|}
\hline \multirow[t]{2}{*}{ Medidas } & \multicolumn{2}{|c|}{ Patawatermes turricola } & \multicolumn{2}{|c|}{ Ruptitermes pitan } \\
\hline & $q \mathrm{n}=5$ & $\delta \mathrm{n}=5$ & q $\mathrm{n}=3$ & $\delta^{1} n=3$ \\
\hline Comprimento da cabeça até a base da mandíbula & $0,92-1,00(0,97)$ & $0,90-1,05(0,98)$ & $1,53-1,58(1,56)$ & $1,38-1,55(1,45)$ \\
\hline Largura da cabeça com olhos & $1,45-1,52(1,48)$ & $1,43-1,48(1,46)$ & $2,15-2,23(2,18)$ & $2,03-2,08(2,05)$ \\
\hline Distância entre os olhos & $1,12-1,20(1,15)$ & $1,10-1,13(1,11)$ & $1,70-1,75(1,73)$ & $1,60-1,68(1,63)$ \\
\hline Diâmetro máximo do olho composto com esclerito & $0,35-0,40(0,37)$ & $0,35-0,37(0,36)$ & $0,45-0,46(0,45)$ & 0,43 \\
\hline Diâmetro máximo do ocelo & $0,12-0,13(0,13)$ & $0,12-0,13(0,12)$ & $0,18-0,20(0,19)$ & $0,18-0,23(0,20)$ \\
\hline Diâmetro mínimo do ocelo & $0,10-0,11(0,10)$ & $0,10-0,15(0,11)$ & $0,13-0,14(0,13)$ & $0,11-0,13(0,11)$ \\
\hline Distância mínima entre olho e ocelo & $0,12-0,17(0,14)$ & 0,13 & $0,23-0,25(0,23)$ & $0,20-0,23(0,22)$ \\
\hline Distância mínima entre olho e margem inferior & 0,05 & $0,04-0,05(0,05)$ & $0,13-0,18(0,15)$ & $0,10-0,13(0,12)$ \\
\hline Comprimento máximo do pronoto & $0,68-0,72(0,70)$ & 0,67 & 1,00 & $0,88-0,90(0,88)$ \\
\hline Largura do pronoto & $1,20-1,28(1,25)$ & $1,20-1,25(1,22)$ & $2,03-2,08(2,05)$ & $1,73-1,83(1,77)$ \\
\hline Comprimento máximo da asa anterior sem escama & - & - & - & - \\
\hline Comprimento máximo da escama alar & $0,62-0,70(0,67)$ & $0,57-0,71(0,65)$ & $1,13-1,18(1,14)$ & $0,95-1,00(0,98)$ \\
\hline Comprimento da tíbia anterior & $0,97-1,05(0,99)$ & $0,92-1,05(0,99)$ & $1,28-1,60(1,46)$ & $1,55-1,65(1,60)$ \\
\hline Largura da tíbia anterior & $0,13-0,15(0,14)$ & $0,13-0,15(0,14)$ & $0,20-0,223(0,22)$ & 0,2 \\
\hline Índice da tíbia anterior (largura/comprimento) & $0,13-0,16(0,15)$ & $0,13-0,16(0,14)$ & $0,14-0,16(0,15)$ & $0,12-0,13(0,13)$ \\
\hline Comprimento da tíbia posterior & $1,42-1,45(1,43)$ & $1,45-1,47(1,47)$ & $2,28-2,35(2,32)$ & $2,28-2,30(2,29)$ \\
\hline $\mathrm{La}$ & 0,13 & - & 0,15 & - \\
\hline L1 & 0,2 & - & 0,42 & - \\
\hline $\mathrm{Ra}$ & 0,12 & - & 0,11 & - \\
\hline R1 & 0,14 & - & 0,20 & - \\
\hline
\end{tabular}




\section{Figuras}




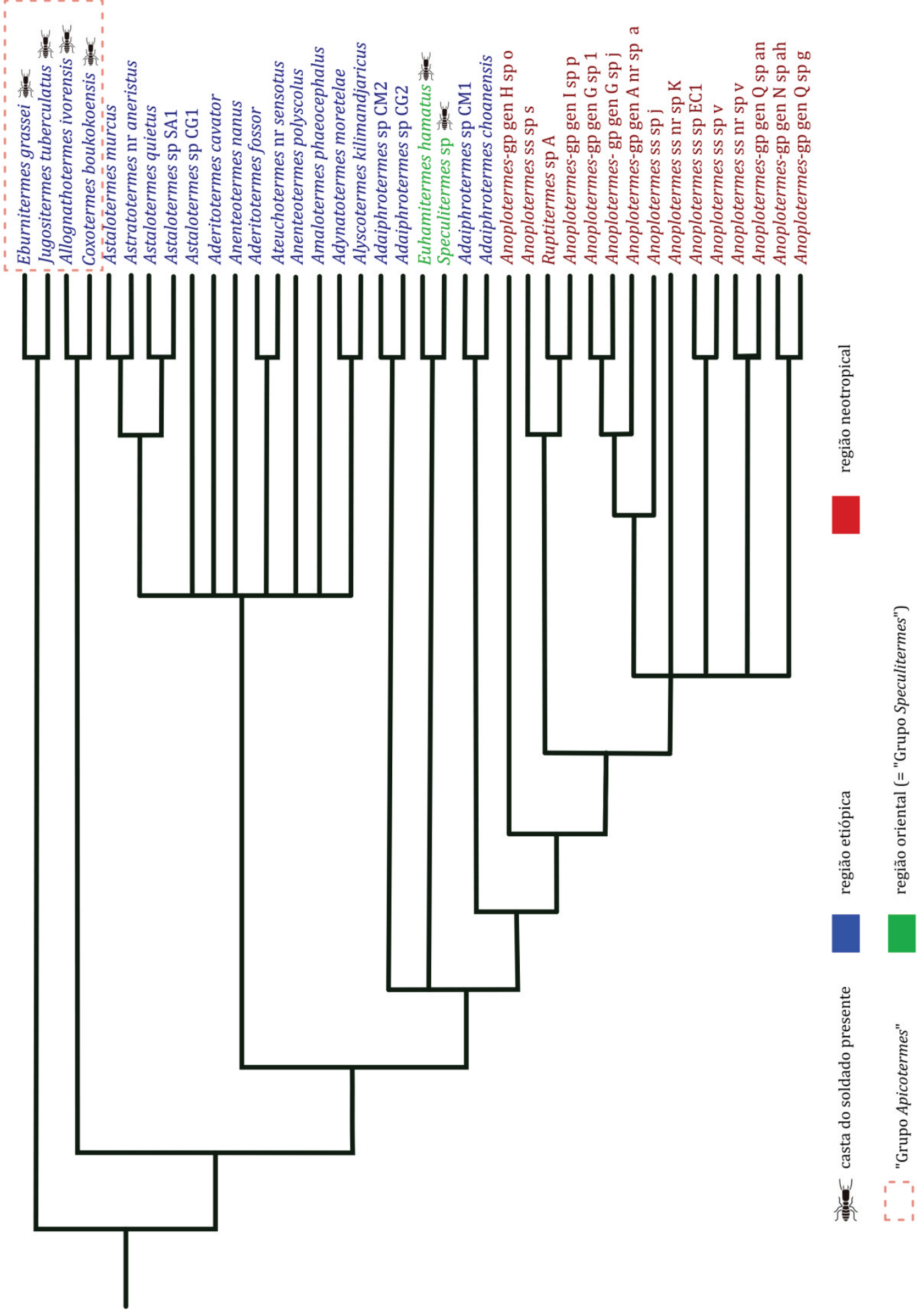

Fig. 1. Filogenia de Inward et al. (2007b), modificada. 
2
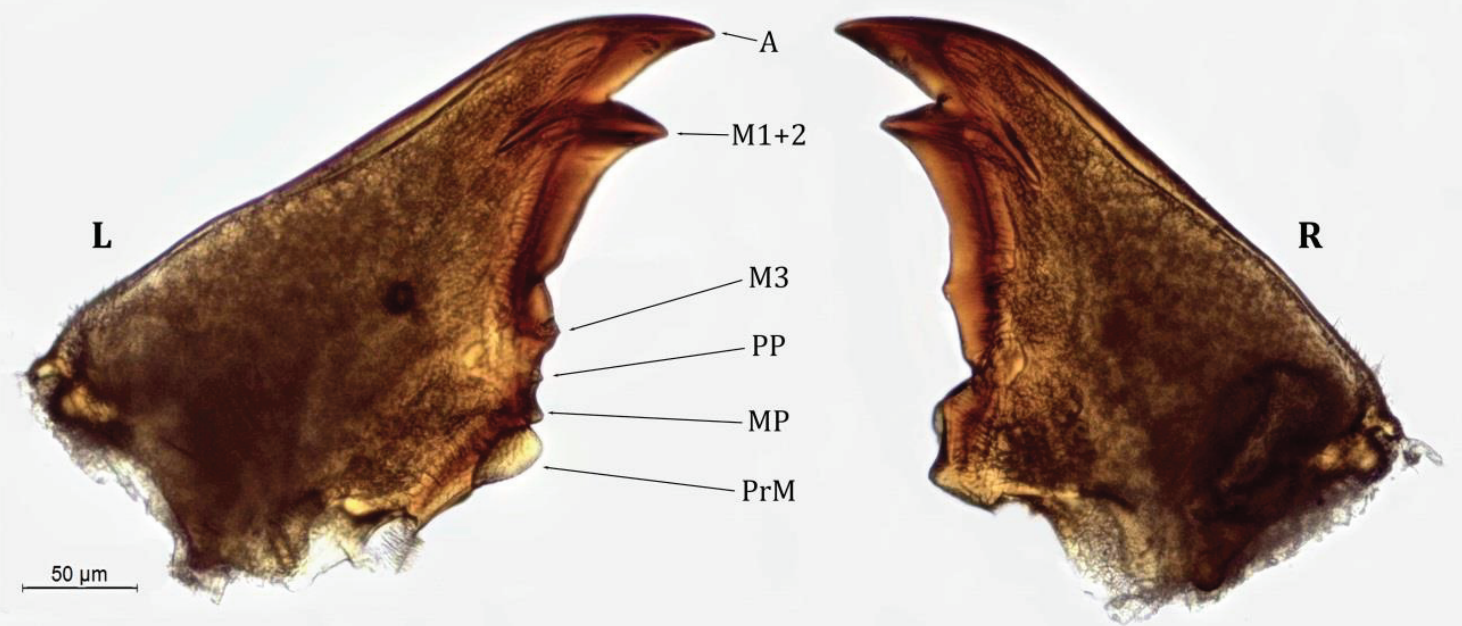

3
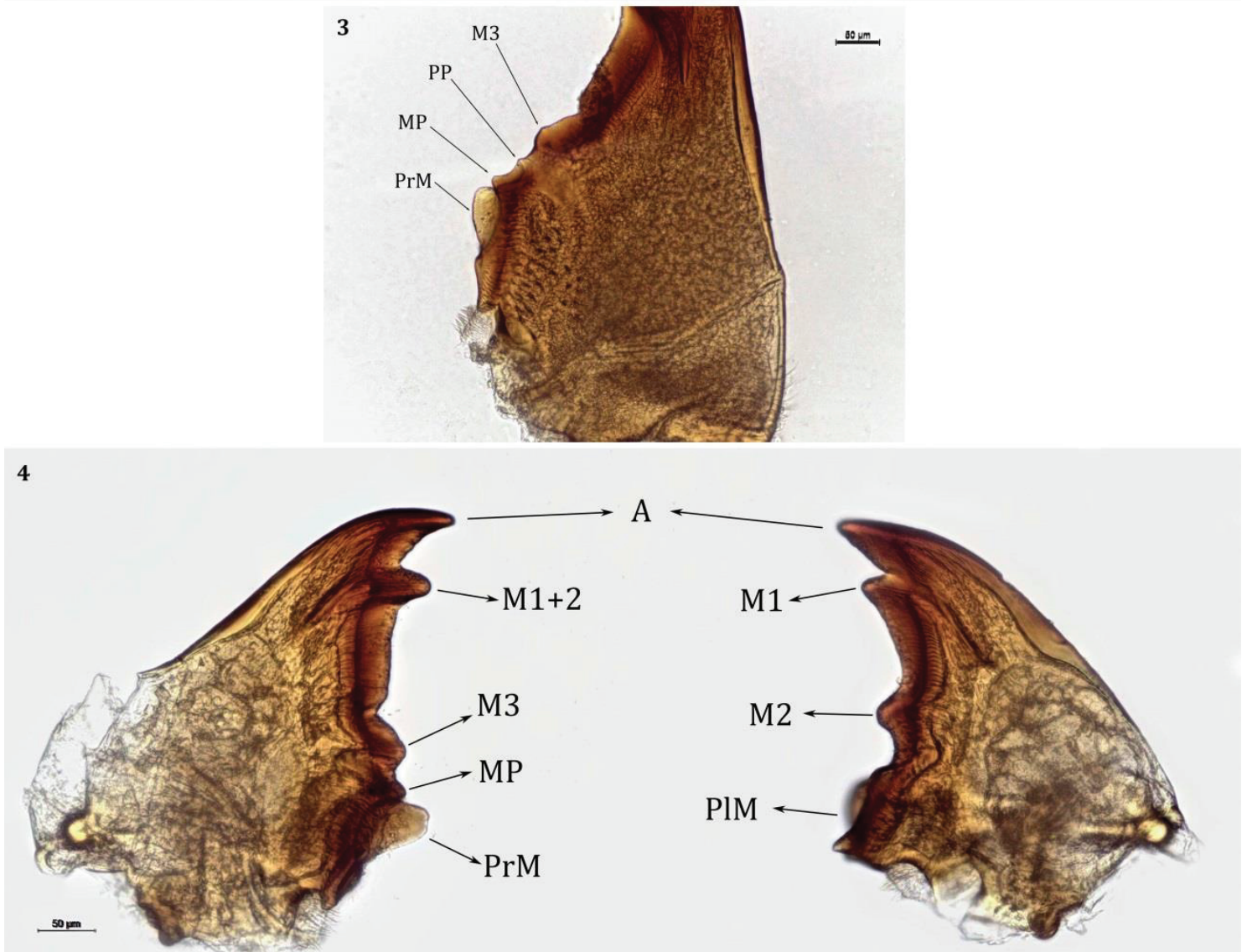

Fig. 2-4. Imagem de referência para mandíbulas. 2- mandíbulas do alado em vista dorsal; 3detalhe da mandíbula esquerda do alado em vista ventral; 4- mandíbulas do operário em vista dorsal. L: esquerda, R: direita, A: dente apical, M1+2: primeiro mais segundo dente marginal; M3: terceiro dente marginal; PP: processo pré-molar; MP: processo molar; PrM: proeminência molar; M1: primeiro dente molar; M2: segundo dente molar; Plm: placa molar. 


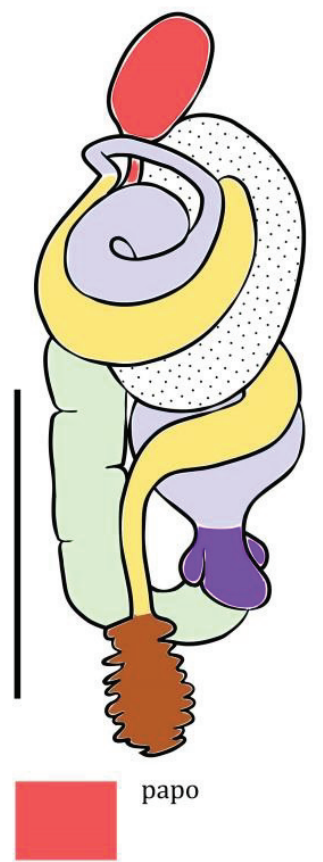

• $\cdot$ mesêntero

$\therefore \therefore$

primeiro segmento proctodeal (P1) ou íleo
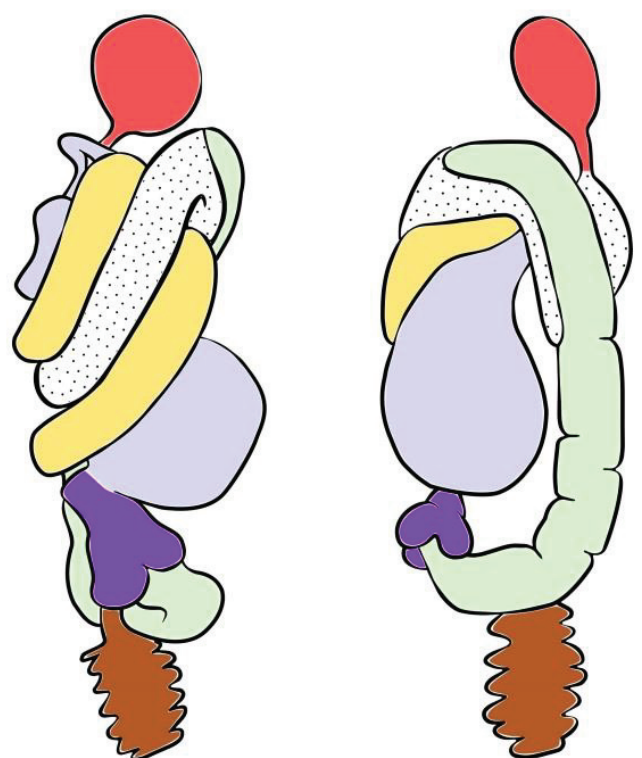

assentamento da válvula entérica (EVS)

terceiro segmento

proctodeal (P3) ou pança

quarto segmento proctodeal (P4) ou colo

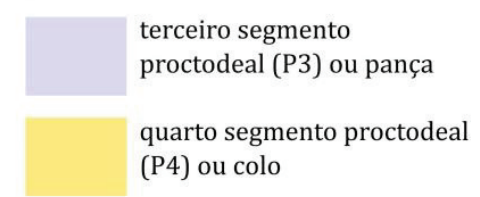

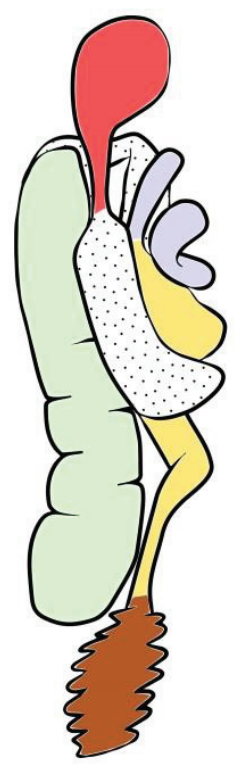

quinto segmento proctodeal (P5) ou reto

Fig. 5. Imagem de referência para o enrolamento do tubo digestório. Da esquerda para a direita vista dorsal, lateral direita, ventral e lateral esquerda, escala: $1 \mathrm{~mm}$. 
6

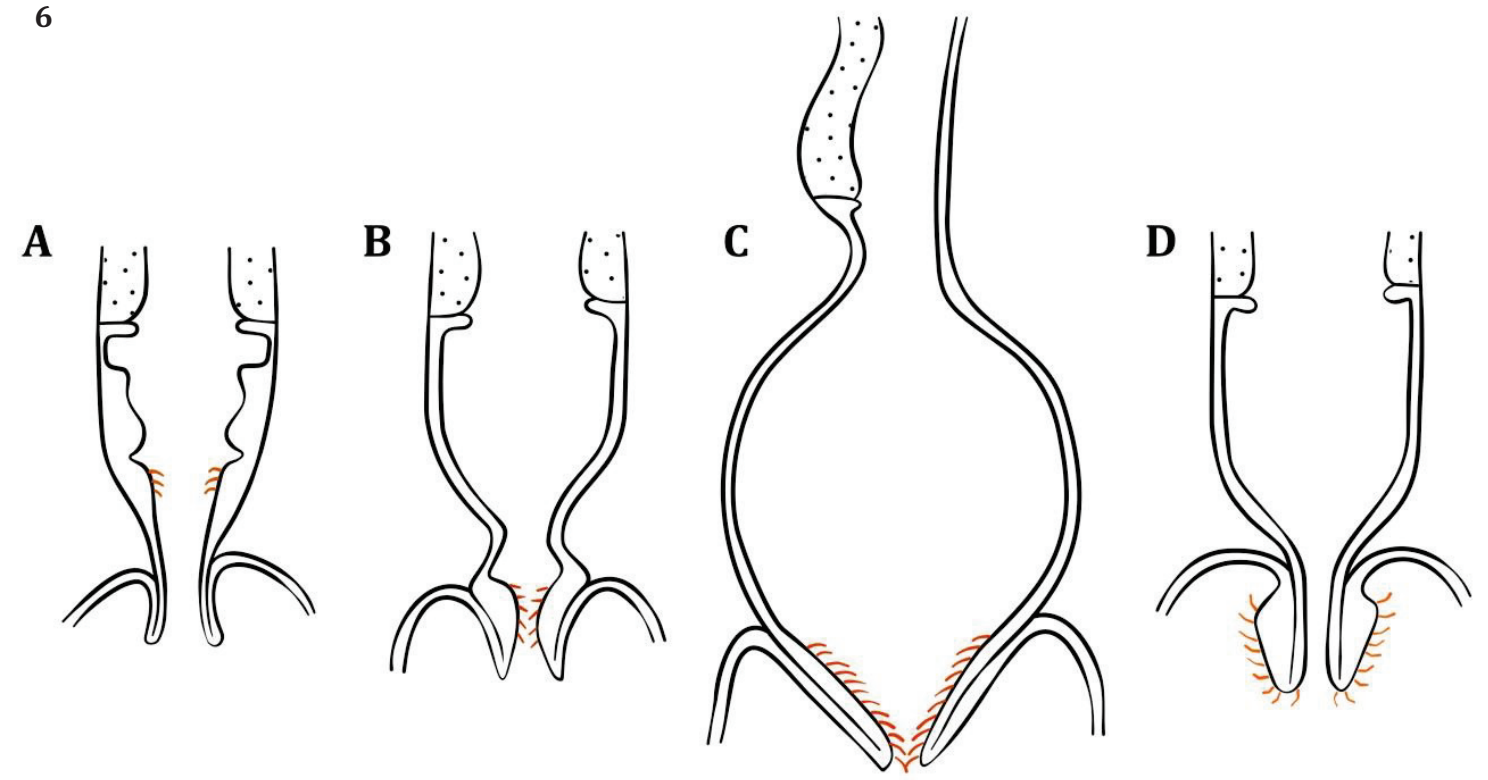

7
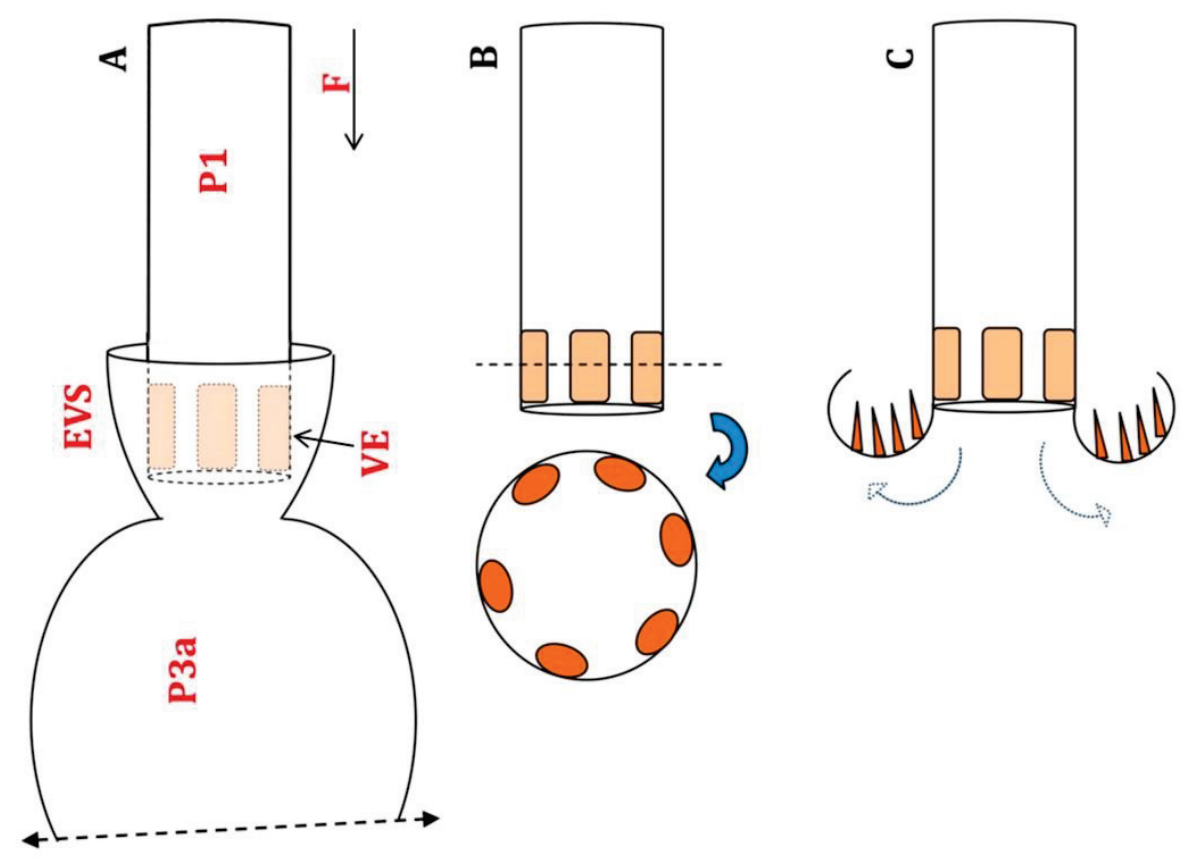

Fig. 6. Esquema de Noirot e Noirot-Thimotée (1969), ilustrando uma hipótese de evolução da válvula entérica. A- cupins não Termitidae; B- Macrotermitinae (Pseudacanthotermes); CCubitermitinae (Thoracotermes); D- Apicotermitinae; áreas pontilhadas indicam o mesêntero. Sem escala. Fig. 7. Esquemas de forma e posicionamento da válvula entérica. A- válvula entérica inerme acomodada no assentamento; B- secção da válvula entérica inerme mostrando as seis pregas simétricas; C- válvula entérica armada indicando a porção esclerotizada extrovertida. Fsentido do fluxo alimentar; P1- íleo; VE-válvula entérica; EVS- assentamento da válvula entérica; P3a- primeira porção da pança. Sem escala. 

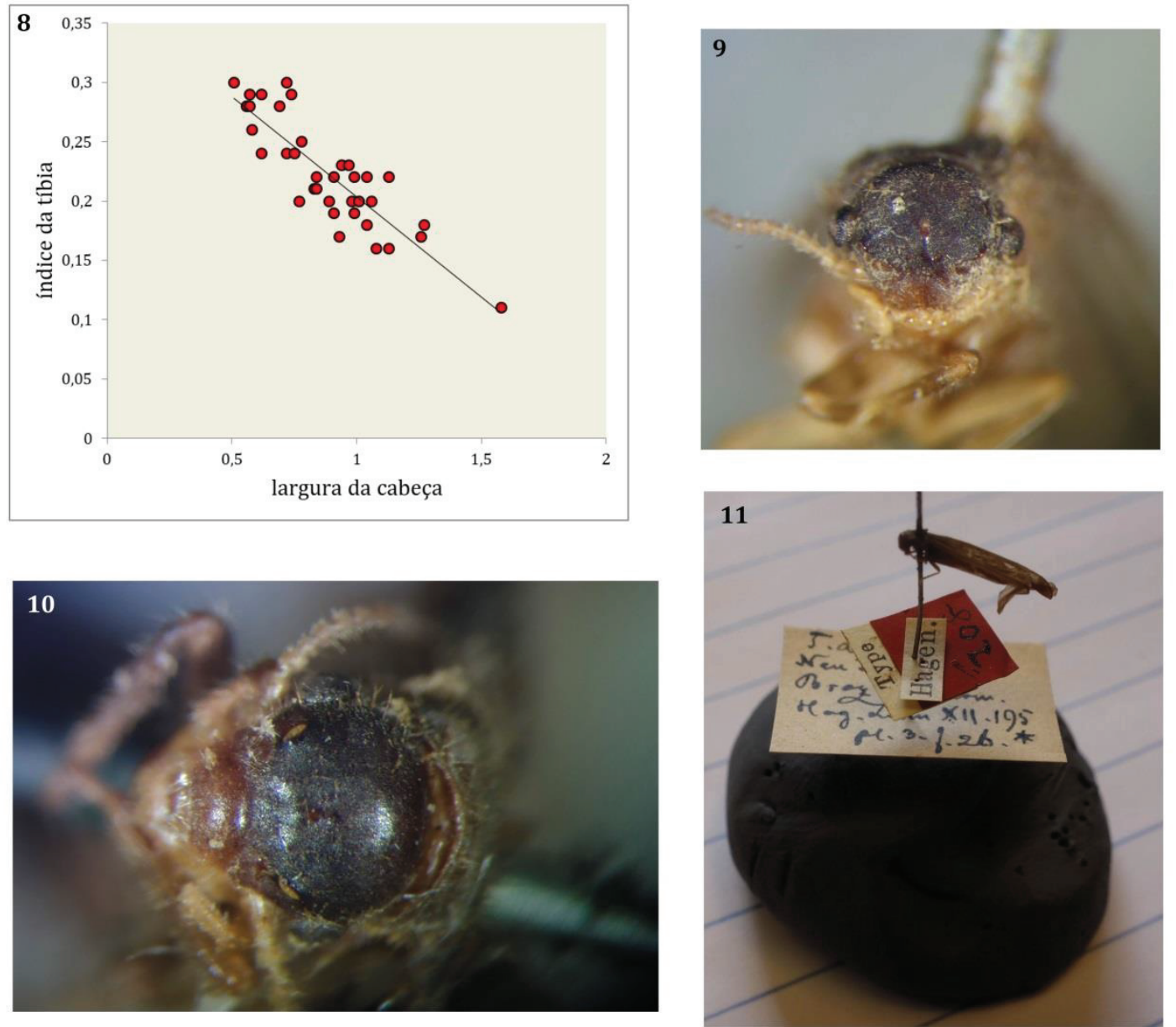

Fig. 8. Correlação entre o índice da tíbia e a largura da cabeça das espécies de Apicotermitinae da Mata Atlântica (ver dados na Tab. 5). Fig. 9-11. Situação do material tipo em montagem seca, crédito das imagens: Reginaldo Constantino. 9- Anoplotermes ater (MCZ); 10- Anoplotermes tenebrosus (MCZ); 11- Aparatermes cingulatus (MCZ). 


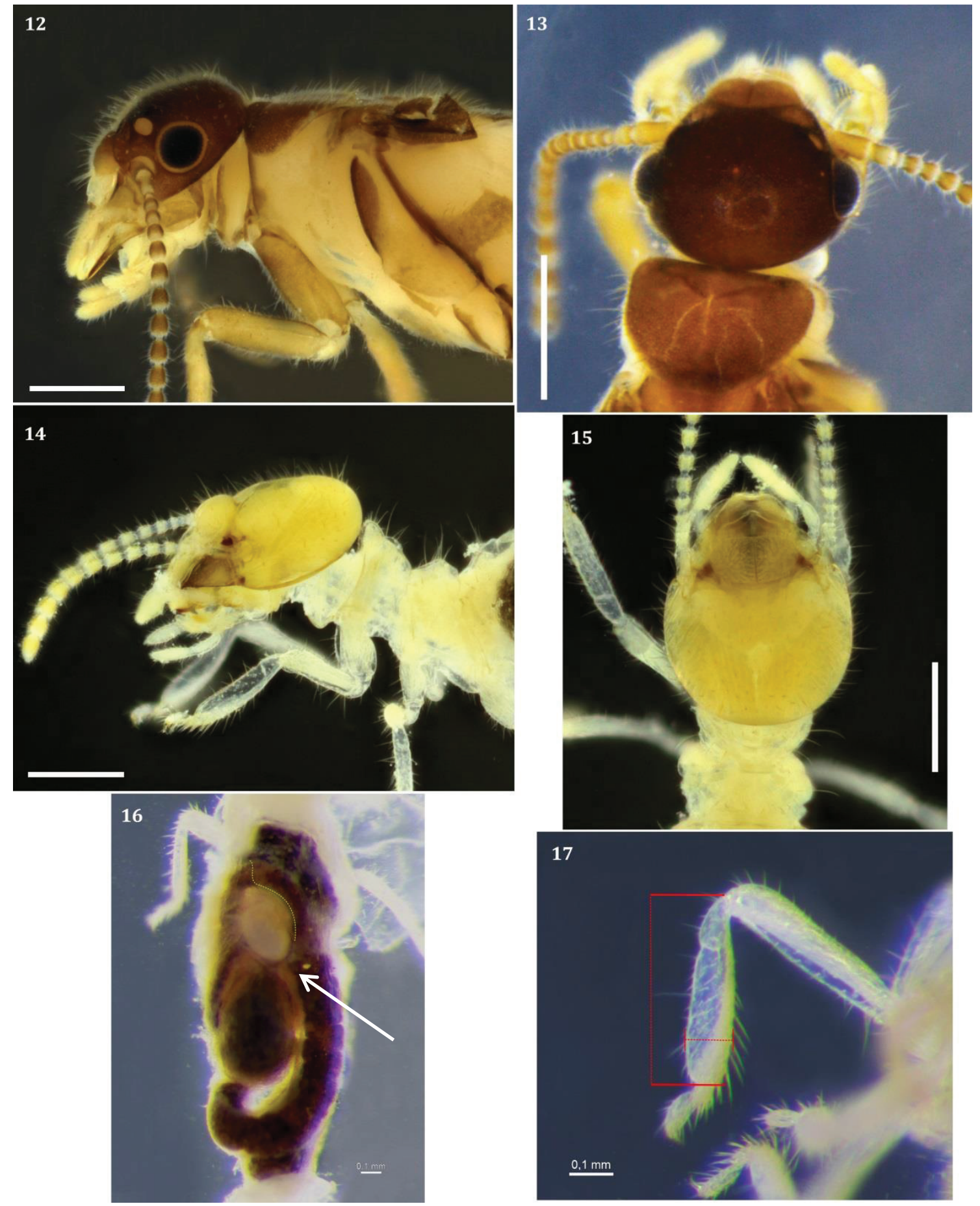

Fig. 12-17. Anoplotermes banksi (MZUSP 22693). 12- alado vista lateral; 13- alado vista dorsal; 14- operário vista lateral; 15- operário vista dorsal; 16- vista ventral do tubo digestório, a seta indica a lingueta mesentérica dilatada; 17- tíbia anterior, as linhas tracejadas em vermelho indicam a forma como a medida da largura e do comprimento foram tomadas. Escalas: 0,5 mm. 

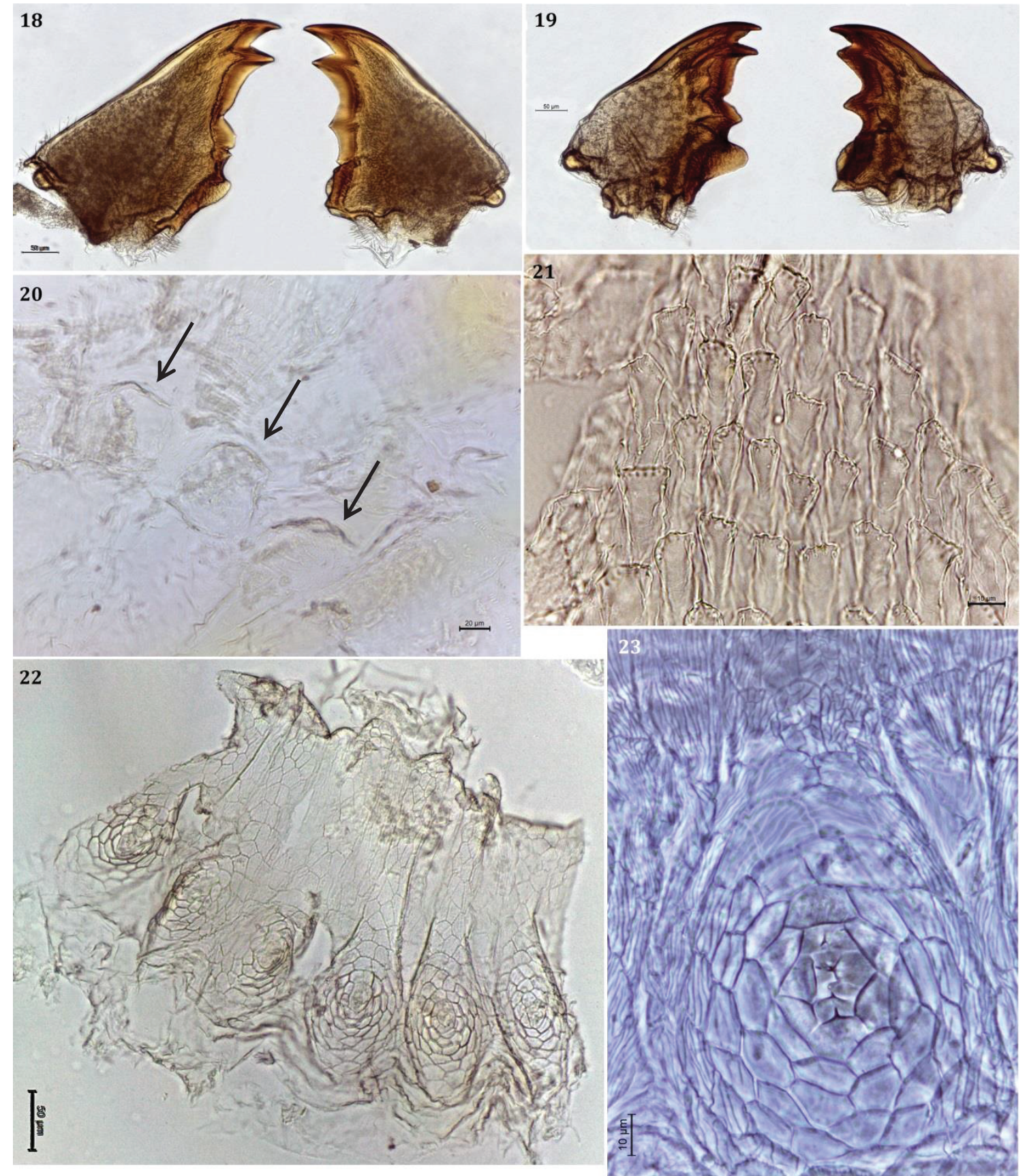

Fig. 18-23. Anoplotermes banksi(MZUSP 22693). 18-mandíbulas do alado; 19-mandíbulas do operário; 20- moela, as setas indicam três dos quatro pulvilli presentes; 21- ornamentação do interior do íleo na região do segmento misto; 22- válvula entérica; 23- detalhe da região central de uma das pregas. 
24
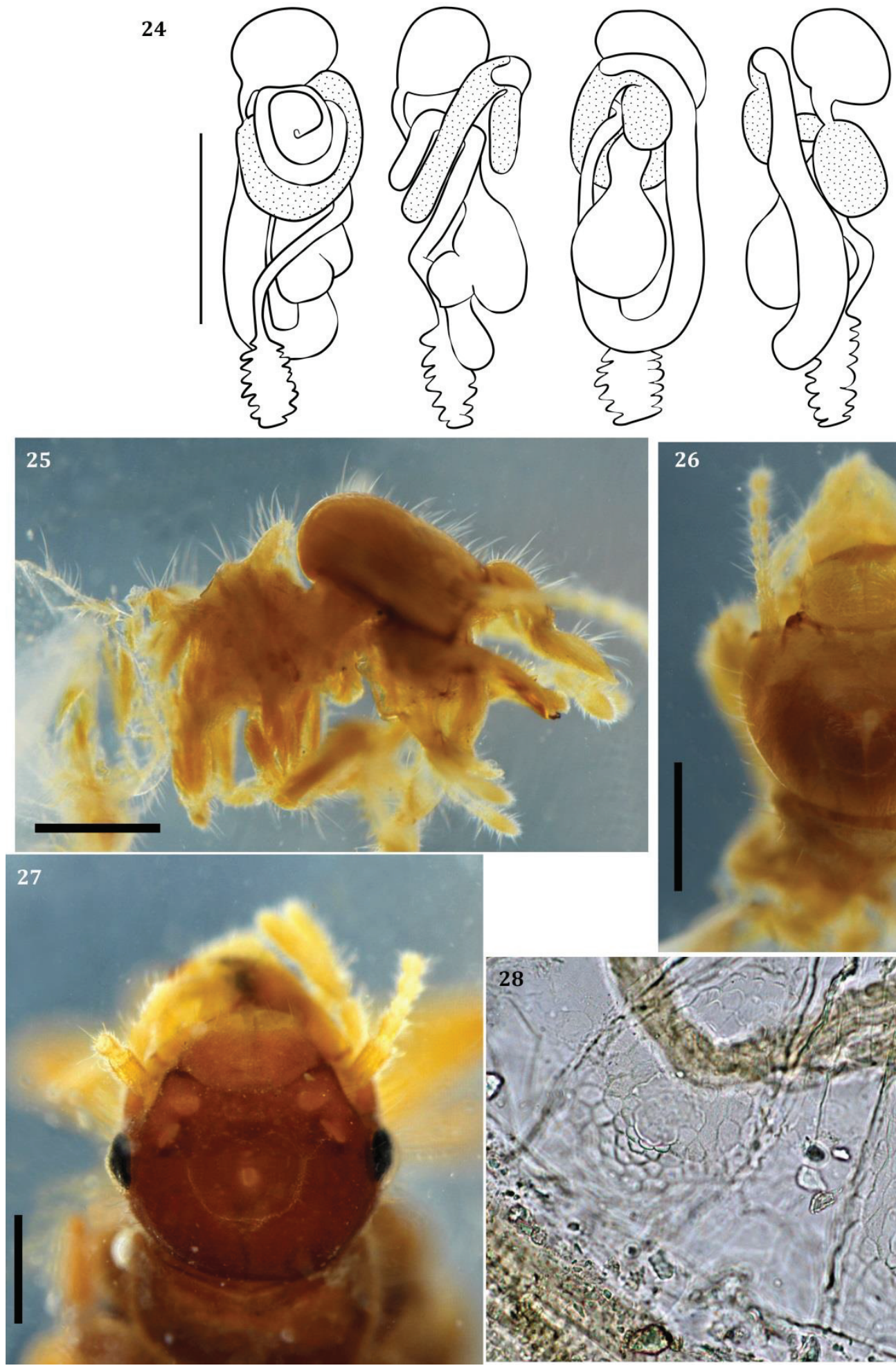

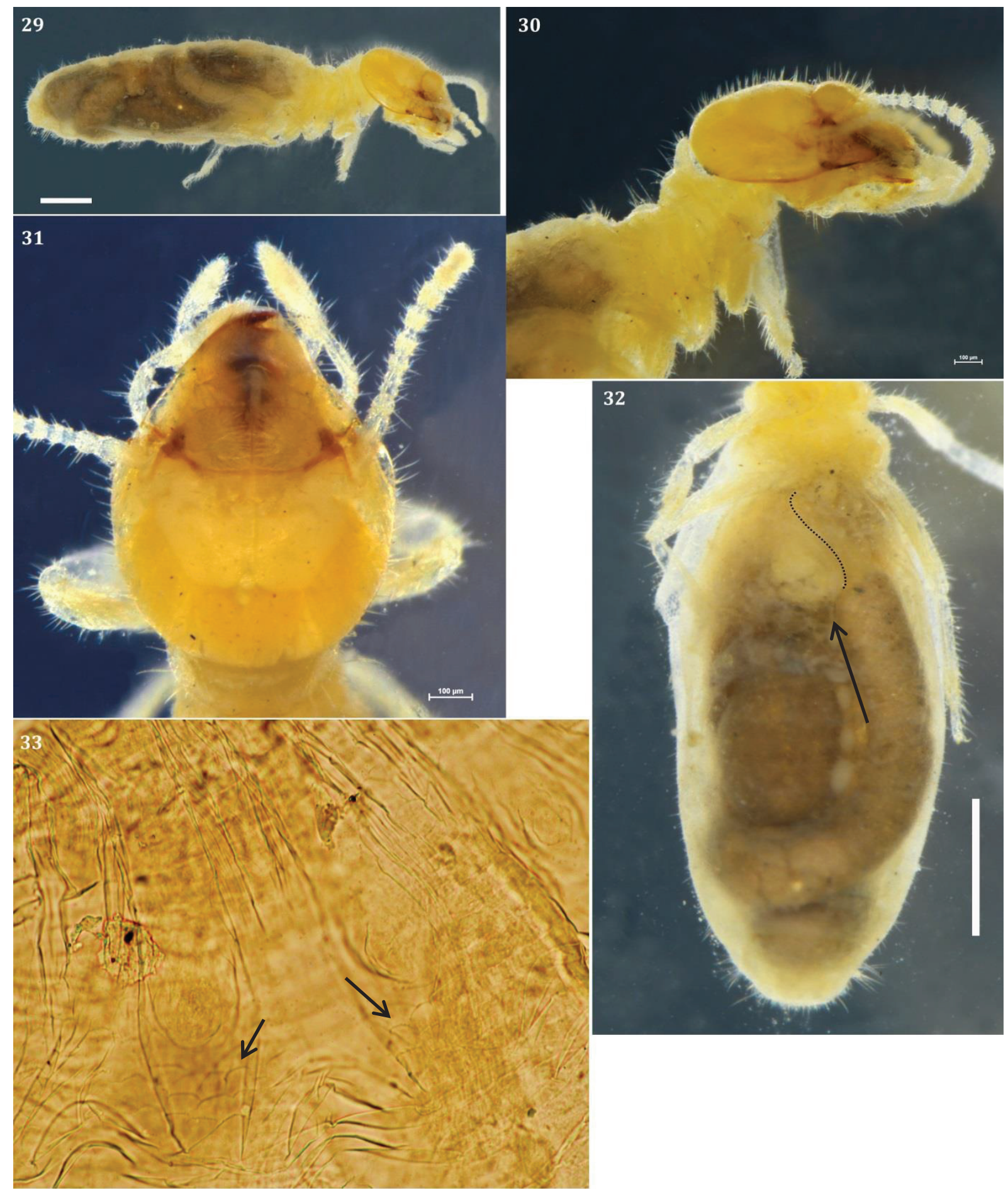

Fig. 29-33. Anoplotermes distans (parátipo AMNH). 29- hábito do operário; 30- operário em vista lateral; 31- operário em vista dorsal; 32- vista ventral do operário a seta indica a região do segmento misto; 33- válvula entérica, as setas indicam a região proximal das prega com escamas visíveis, sem escala. Escalas: $0,5 \mathrm{~mm}$. 


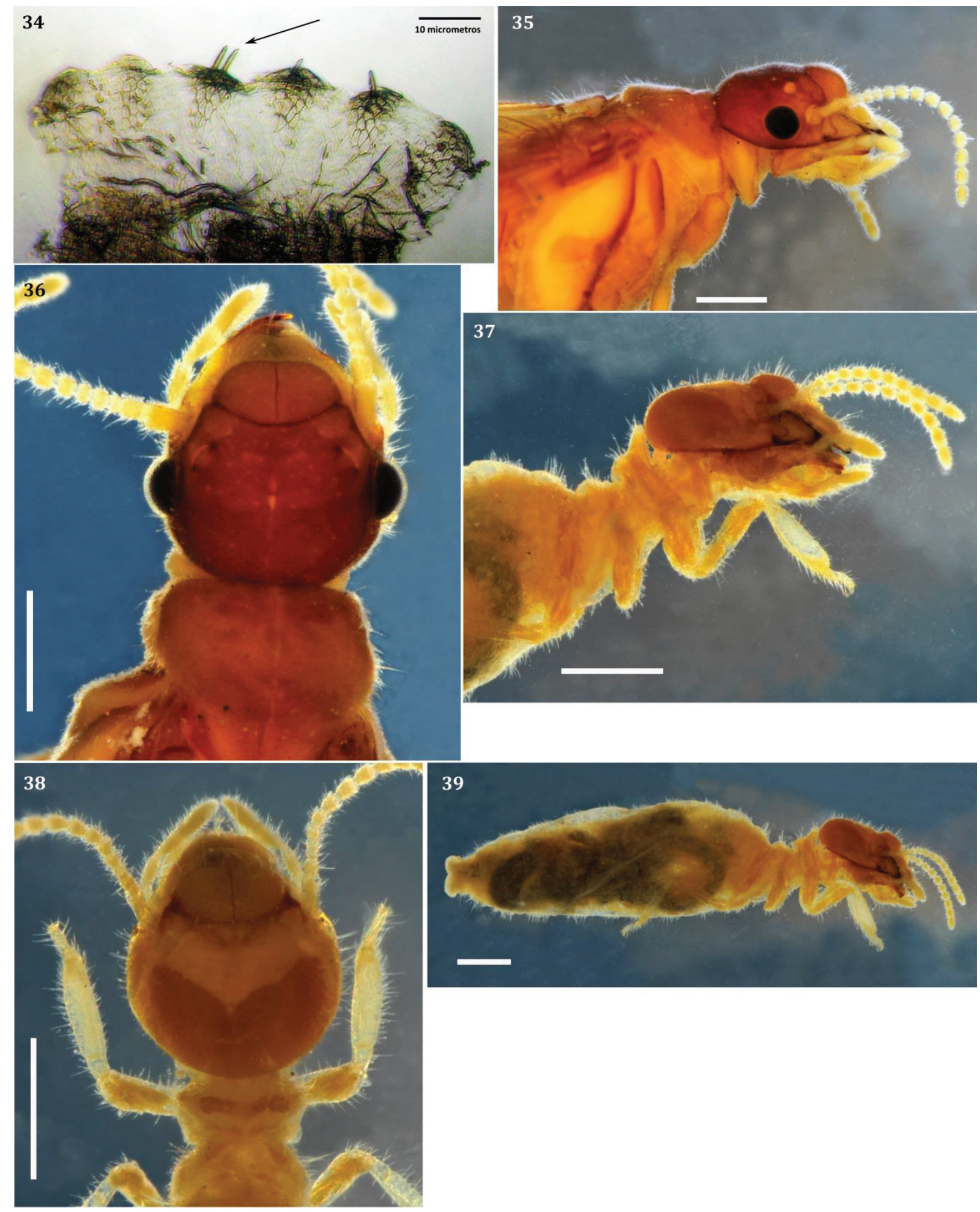

Fig. 34. Válvula entérica de Anoplotermes janus (MZUSP 17762), a seta indica a prega que apresenta dois espinhos, crédito da imagem: Tiago Carrijo. Fig. 35-39. Anoplotermes meridianus (parátipo AMNH). 35- alado em vista lateral; 36- alado em vista dorsal; 37- operário em vista lateral; 38-operário em vista dorsal; 39- hábito do operário. Escalas: 0,5mm. 

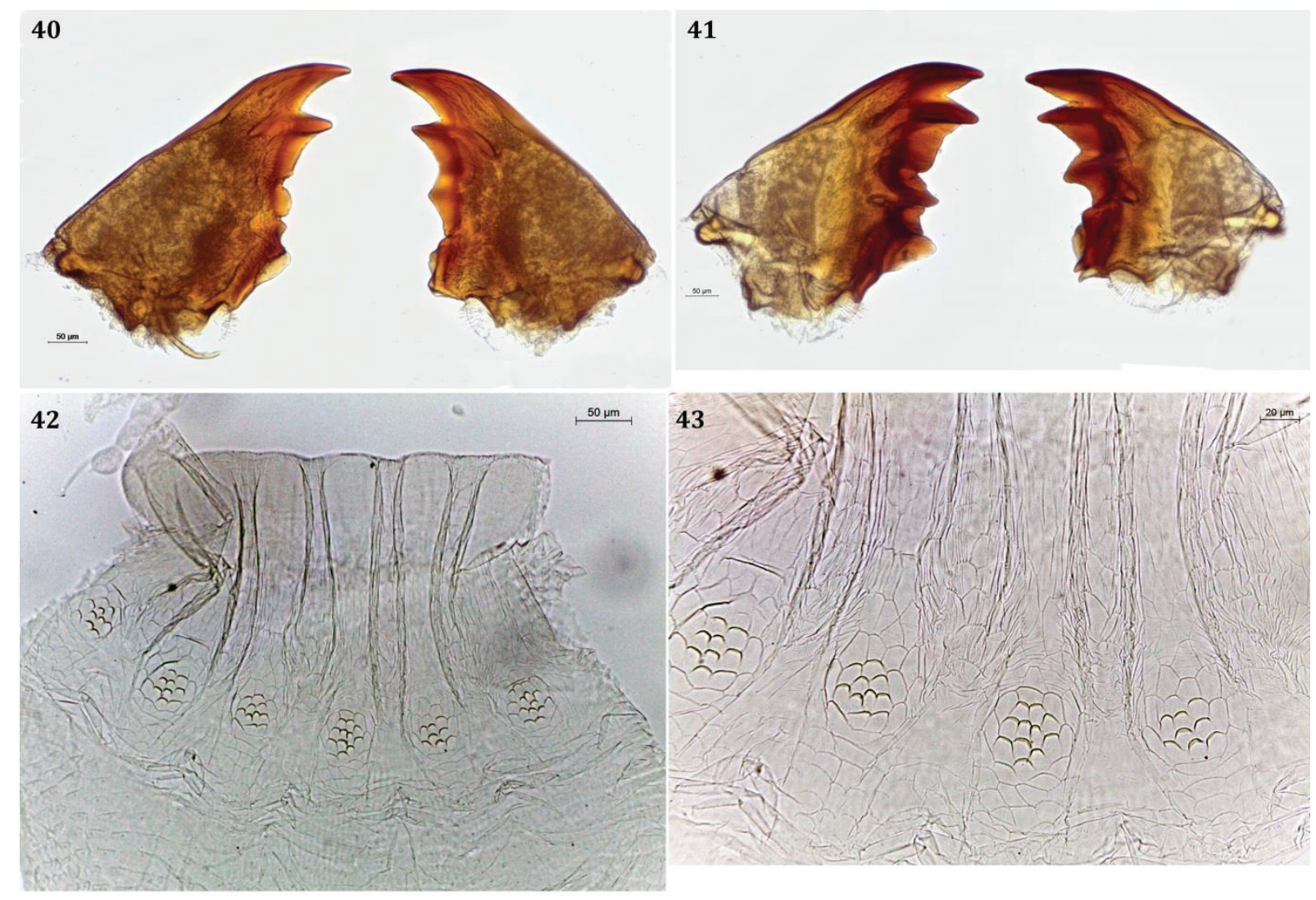

44
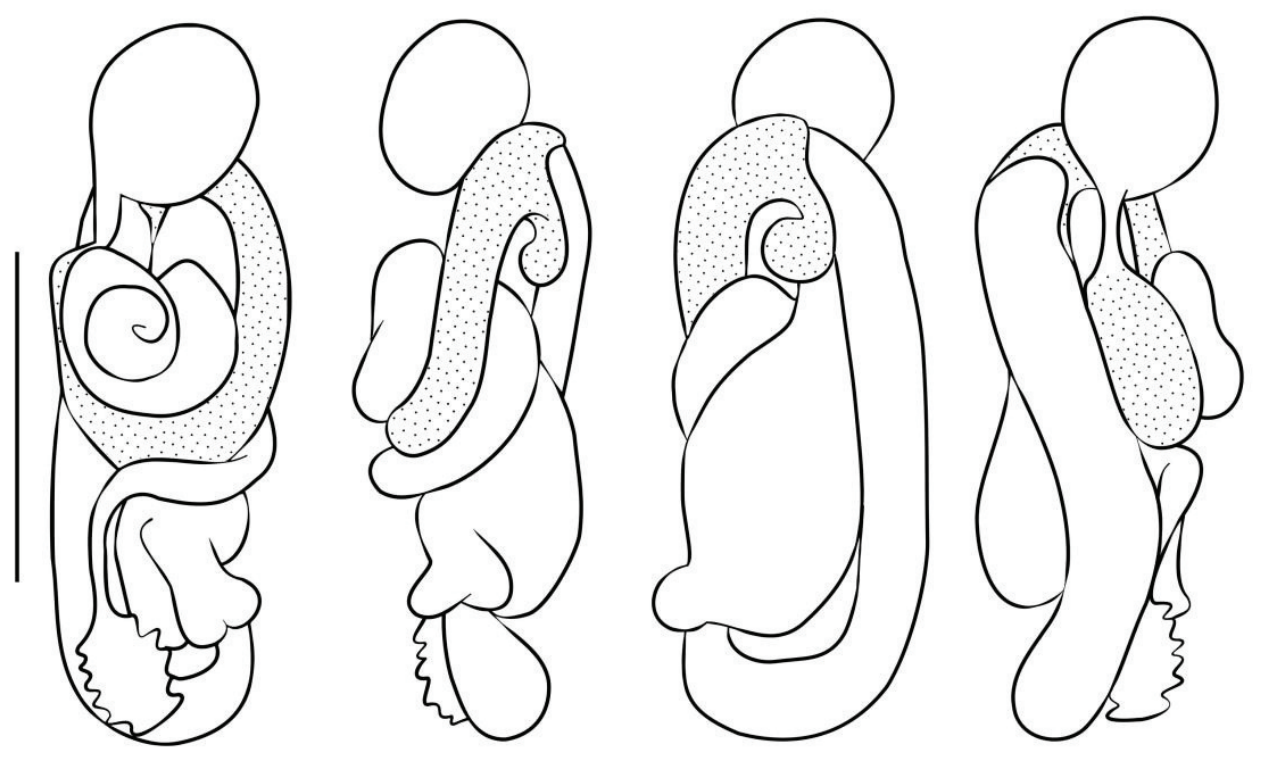

Fig. 40-44. Anoplotermes meridianus (MZUSP 4740). 40- mandíbulas do alado; 41- mandíbulas do operário; 42- válvula entérica; 43- detalhe da válvula entérica; 44- esquema de tubo digestório, escala: $1 \mathrm{~mm}$. 

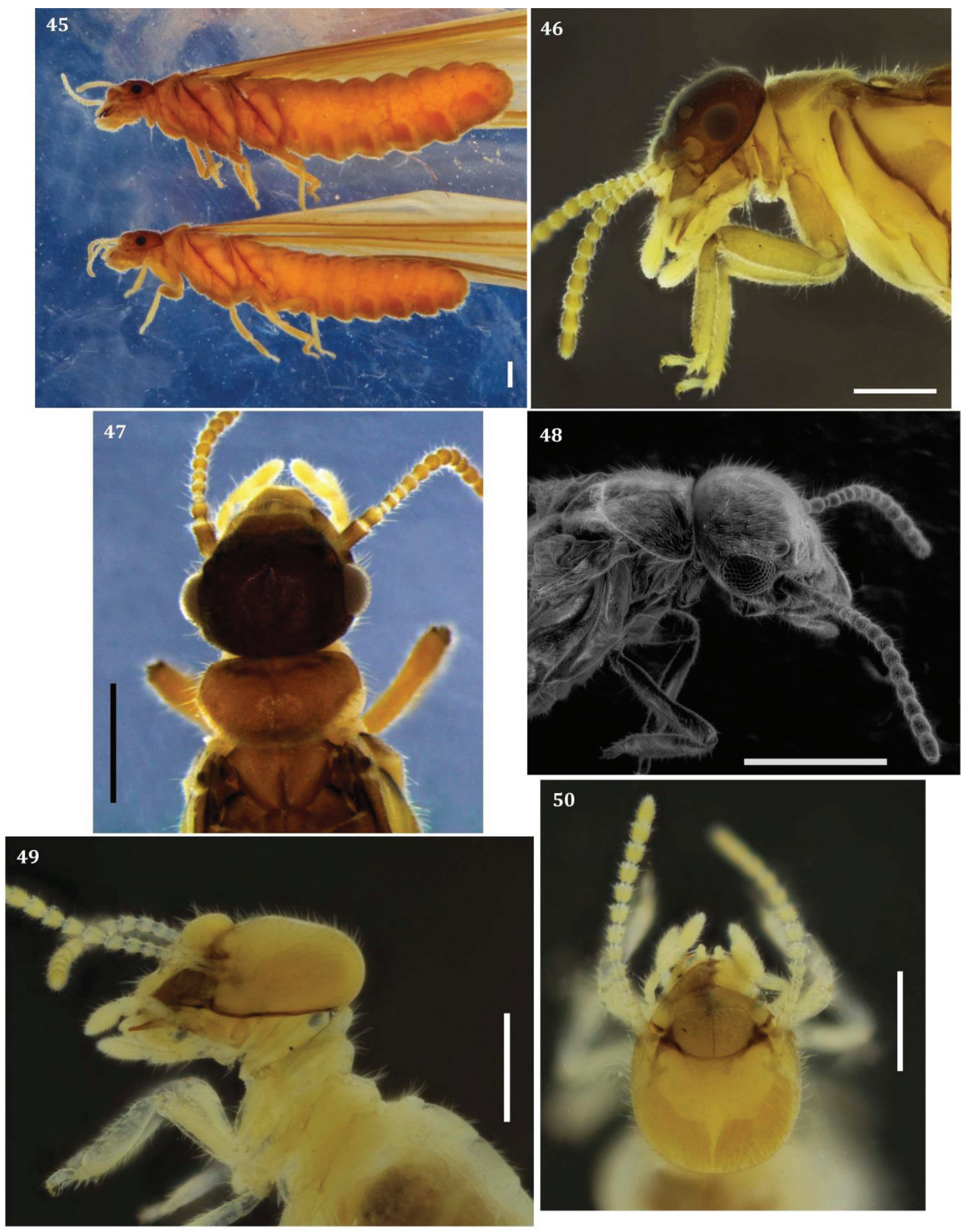

Fig. 45. Anoplotermes meridianus (parátipo AMNH), fêmea alada acima e macho abaixo, para comparação do tamanho. Fig. 46-50. Anoplotermes pacificus (MZUSP 3202). 46- alado em vista lateral; 47- alado em vista dorsal; 48- alado em vista lateral (MEV), evidenciando cerdas (base larga, maiores e mais claros) e pelos (bases menos evidentes); 49- operário em vista lateral; 50operário em vista dorsal. Escalas: 0,5mm. 

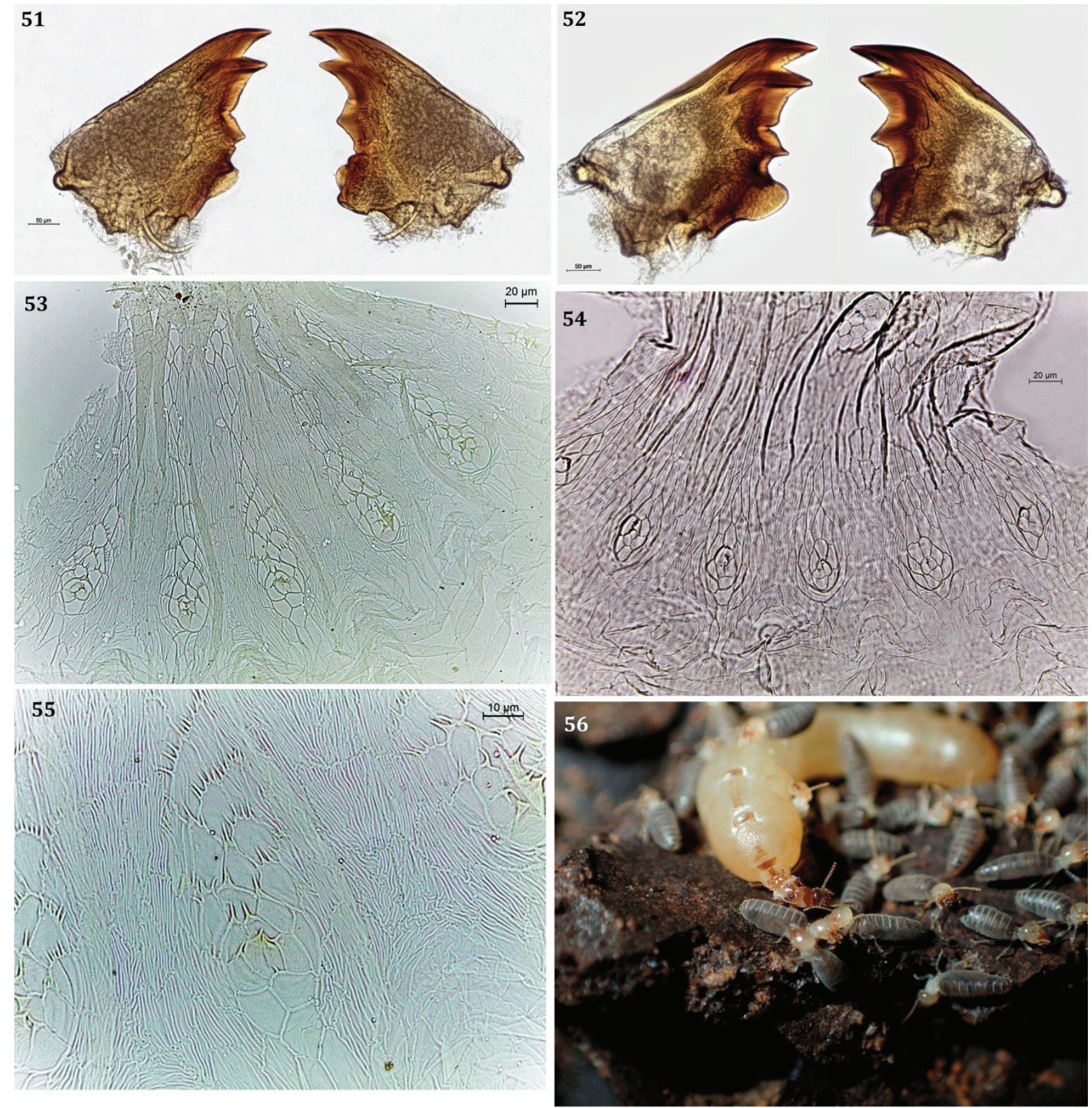

Fig. 51-56. Anoplotermes pacificus. 51- mandíbulas do alado (MZUSP 3202); 52- mandíbulas do operário (MZUSP 3202); 53- válvula entérica (MZUSP 12178, Ilha do Cardoso, SP), note que a margem das escamas apresentam espinhos; 54-válvula entérica (MZUSP 26672, Santa Teresa, ES), note que a margem das escamas são lisas; 55- detalhe da região bojuda da válvula entérica. 56-Anoplotermes pacificus, rainha primária e operários (MZUSP 25554), créditos da imagem: Tiago Carrijo. 




Fig. 57-60. Anoplotermes punctatus (parátipo AMNH). 57- operário em vista lateral; 58- operário em vista dorsal; 59- válvula entérica com três das seis pregas visíveis; 60- detalhe da região central da válvula entérica. Fig. 61-62. Anoplotermes pyriformis (parátipo AMNH). 61- fêmea alada em vista lateral; 62- fêmea alada em vista dorsal. Escalas: 0,5 mm. 

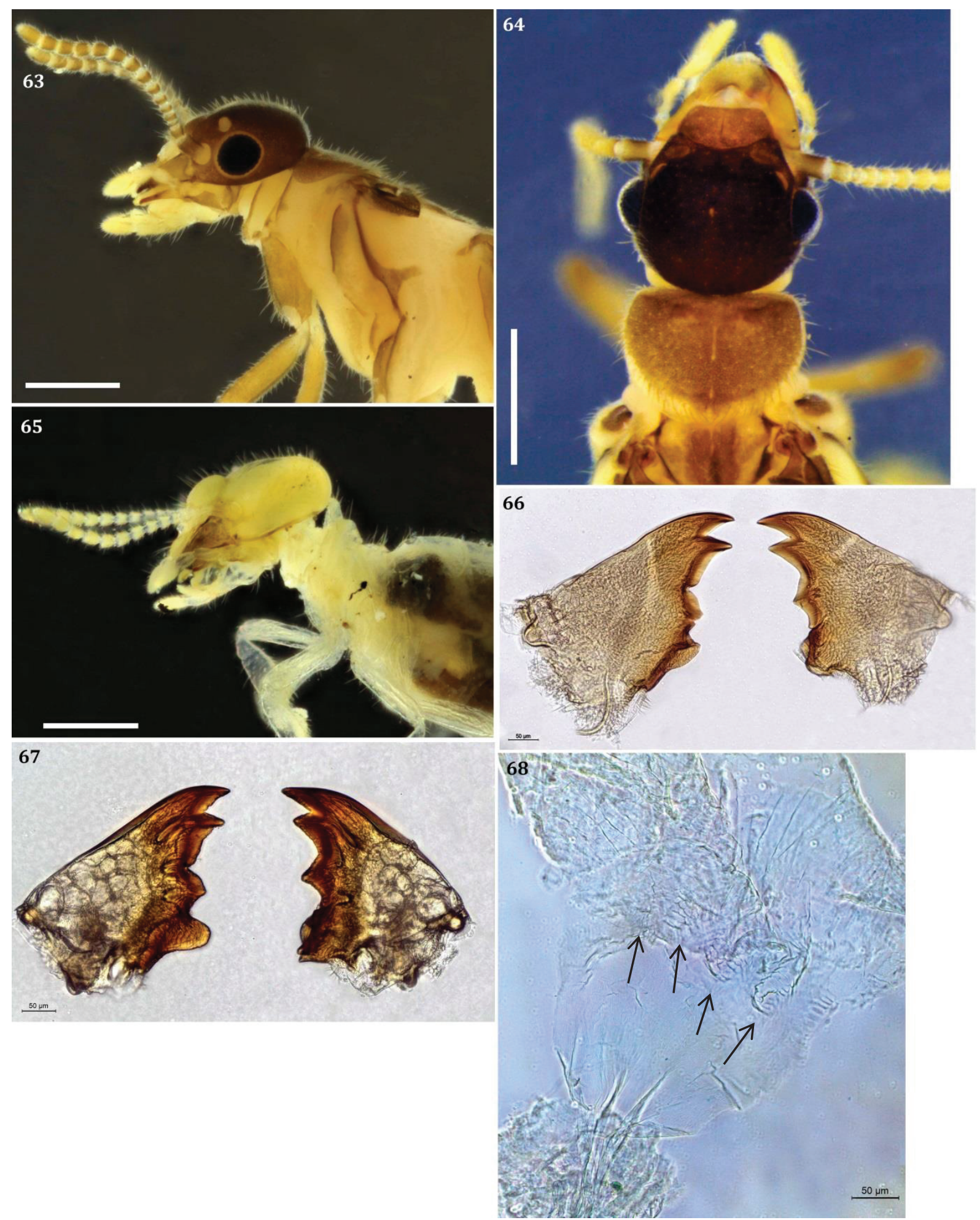

Fig. 63-68. Anoplotermes sp. 1 (MZUSP 25514). 63- alado em vista lateral; 64- alado em vista dorsal; 65- operário em vista dorsal; 66- mandíbulas do alado; 67- mandíbulas do operário; 68moela, as setas indicam os quatro pulvilli. Escalas: $0,5 \mathrm{~mm}$. 

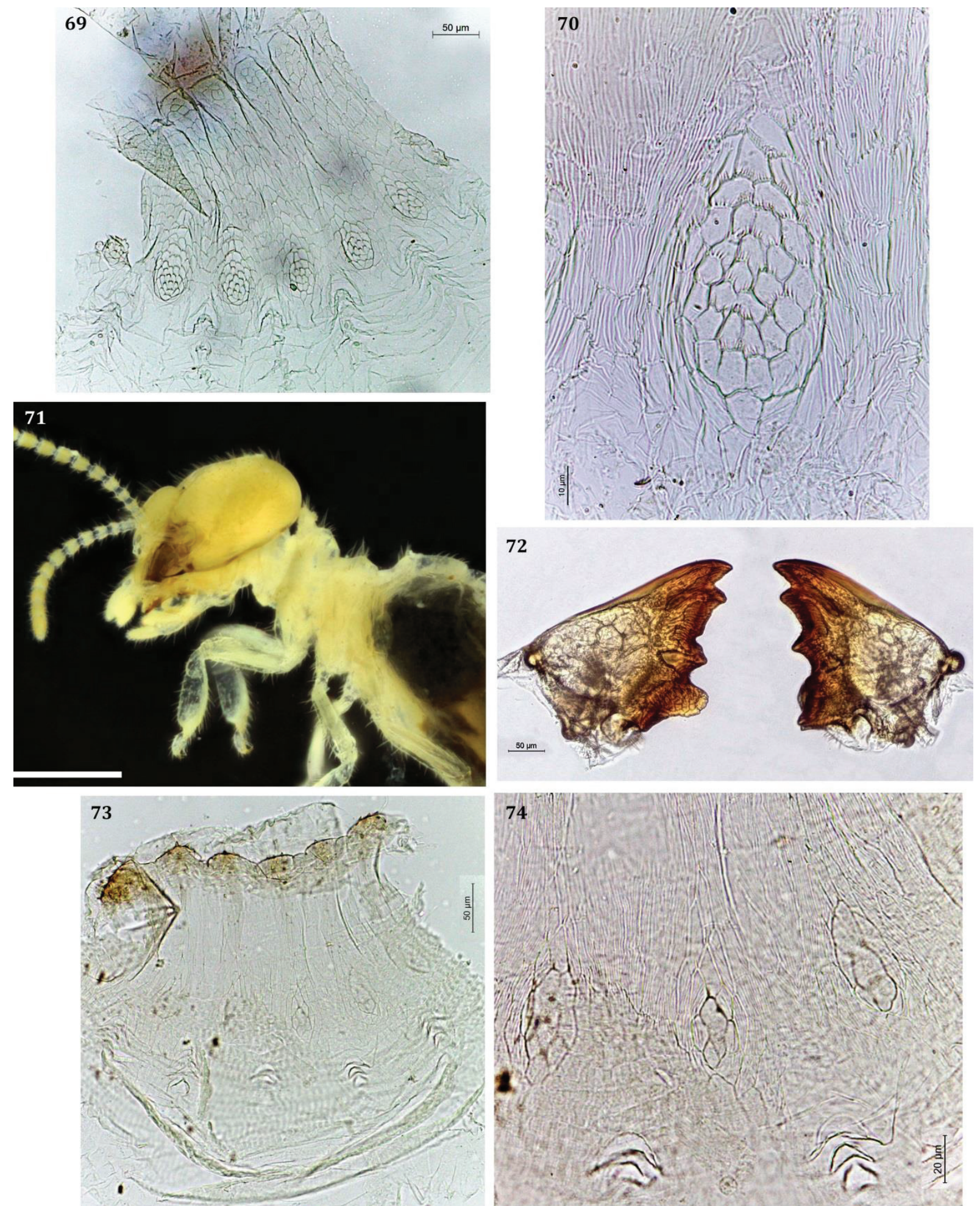

Fig. 69-70. Anoplotermes sp. 1 (MZUSP 25514). 69- válvula entérica; 70- detalhe da região proximal da válvula entérica. Fig. 71-74. Anoplotermes sp. 2 (MZUSP 25467). 71- operário em vista lateral, escala: 0,5 mm; 72- mandíbulas do operário; 73- válvula entérica; 74- detalhe da válvula entérica. 

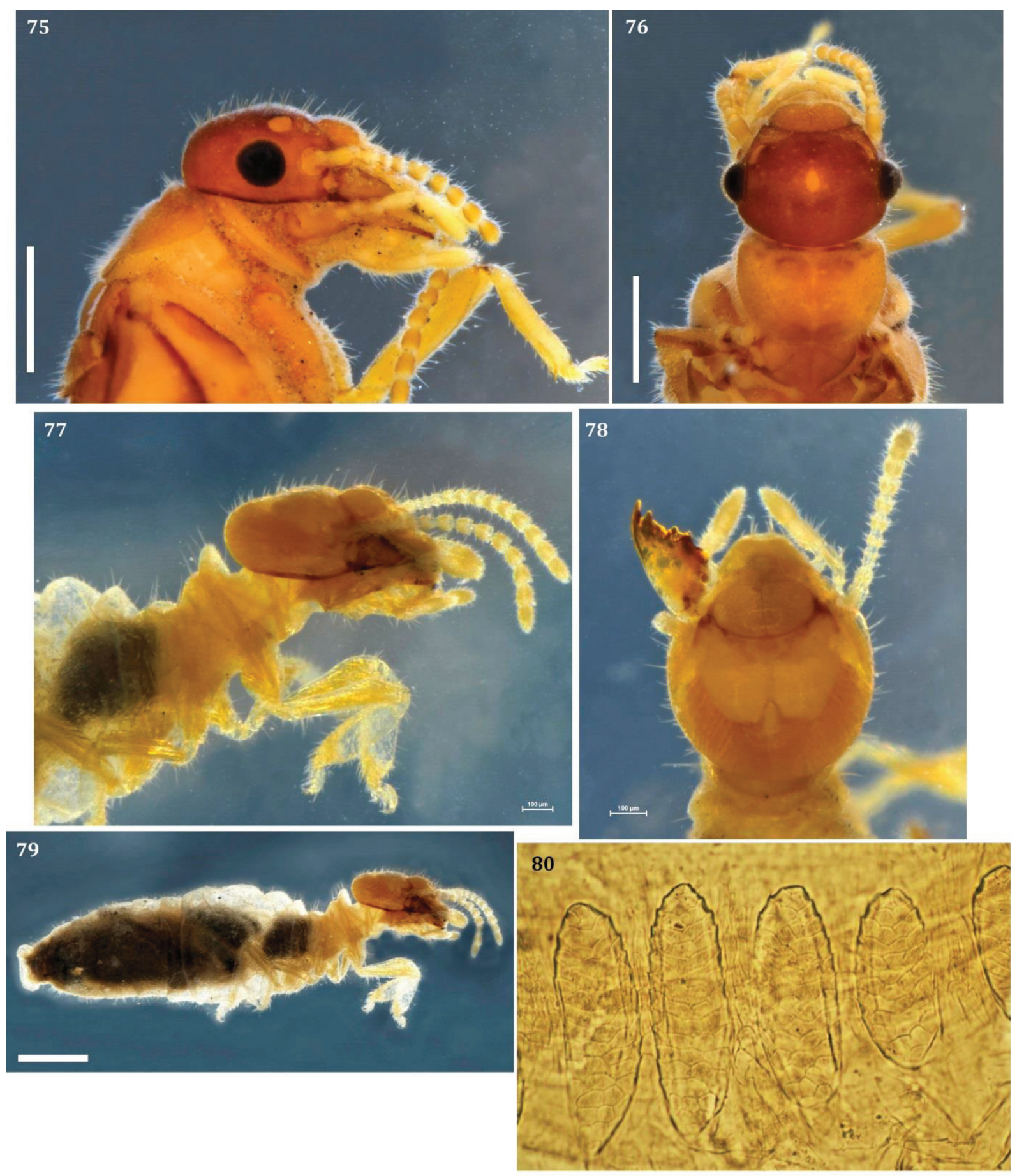

Fig. 75-80. Anoplotermes subterraneus (parátipo AMNH). 75- alado em vista lateral; 76-alado em vista dorsal; 77- operário em vista lateral; 78- operário em vista dorsal. 79- hábito do operário; 80- detalhe da válvula entérica com quatro das seis pregas visíveis. Escalas: 0,5 mm. 

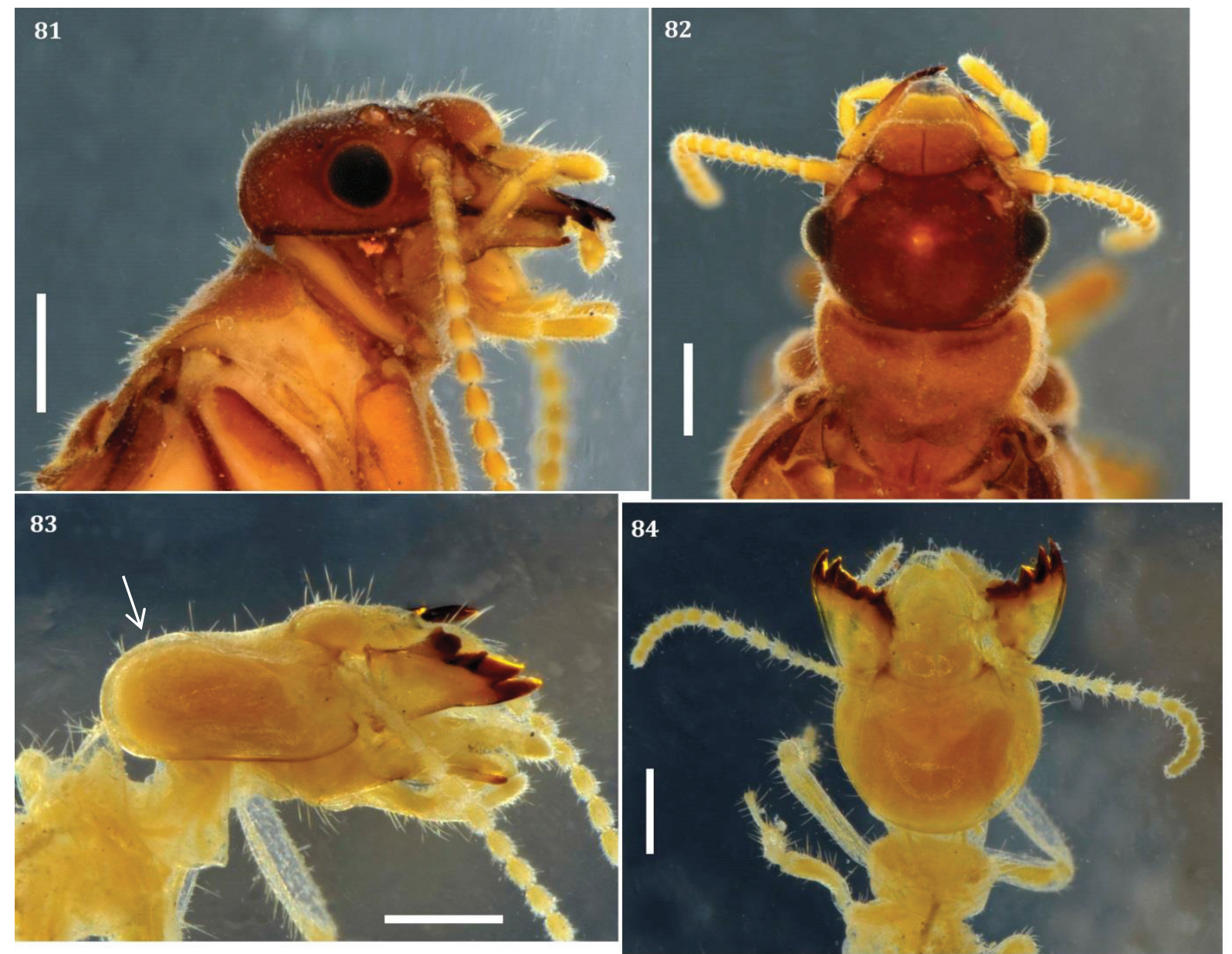

85
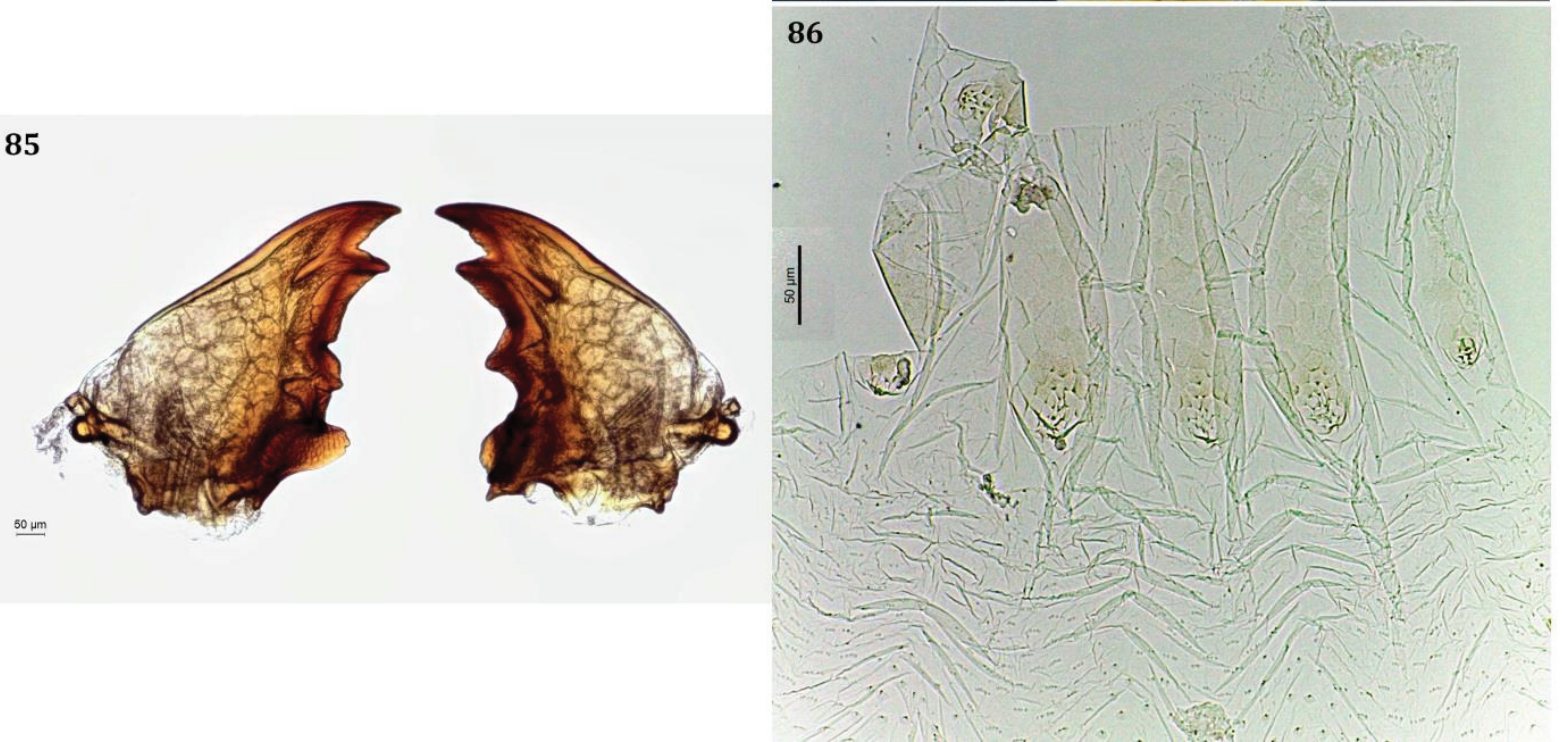

Fig. 81-86. Aparatermes abbreviatus. 81- alado em vista lateral (síntipo AMNH); 82- alado em vista dorsal (síntipo AMNH); 83- operário em vista lateral (síntipo AMNH); 84- operário em vista dorsal (síntipo AMNH); 85- mandíbulas do operário (MZUSP 26920); 86- válvula entérica com quatro das seis pregas íntegras (MZUSP 26920). Escalas: 0,5mm. 


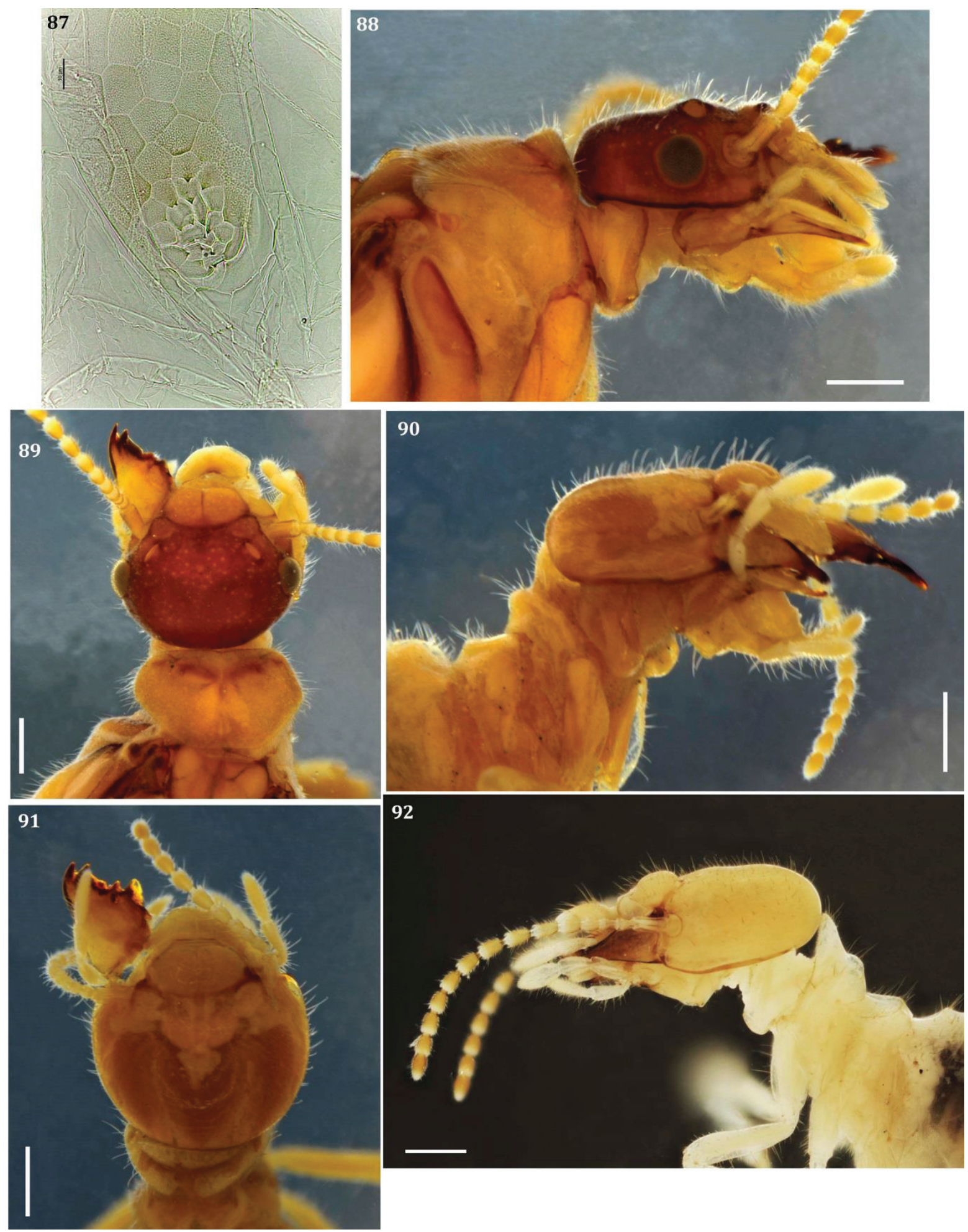

Fig. 87. Aparatermes abbreviatus (MZUSP 26920), detalhe da região proximal da válvula entérica. Fig. 88-92. Aparatermes cingulatus. 88- alado em vista lateral (amostra AMNH); 89alado em vista dorsal (amostra $\mathrm{AMNH}$ ); 90- operário em vista lateral (amostra AMNH); 91operário dorsal (amostra AMNH); 92- operário em vista lateral (MZUSP 25542). Escala: 0,5mm. 

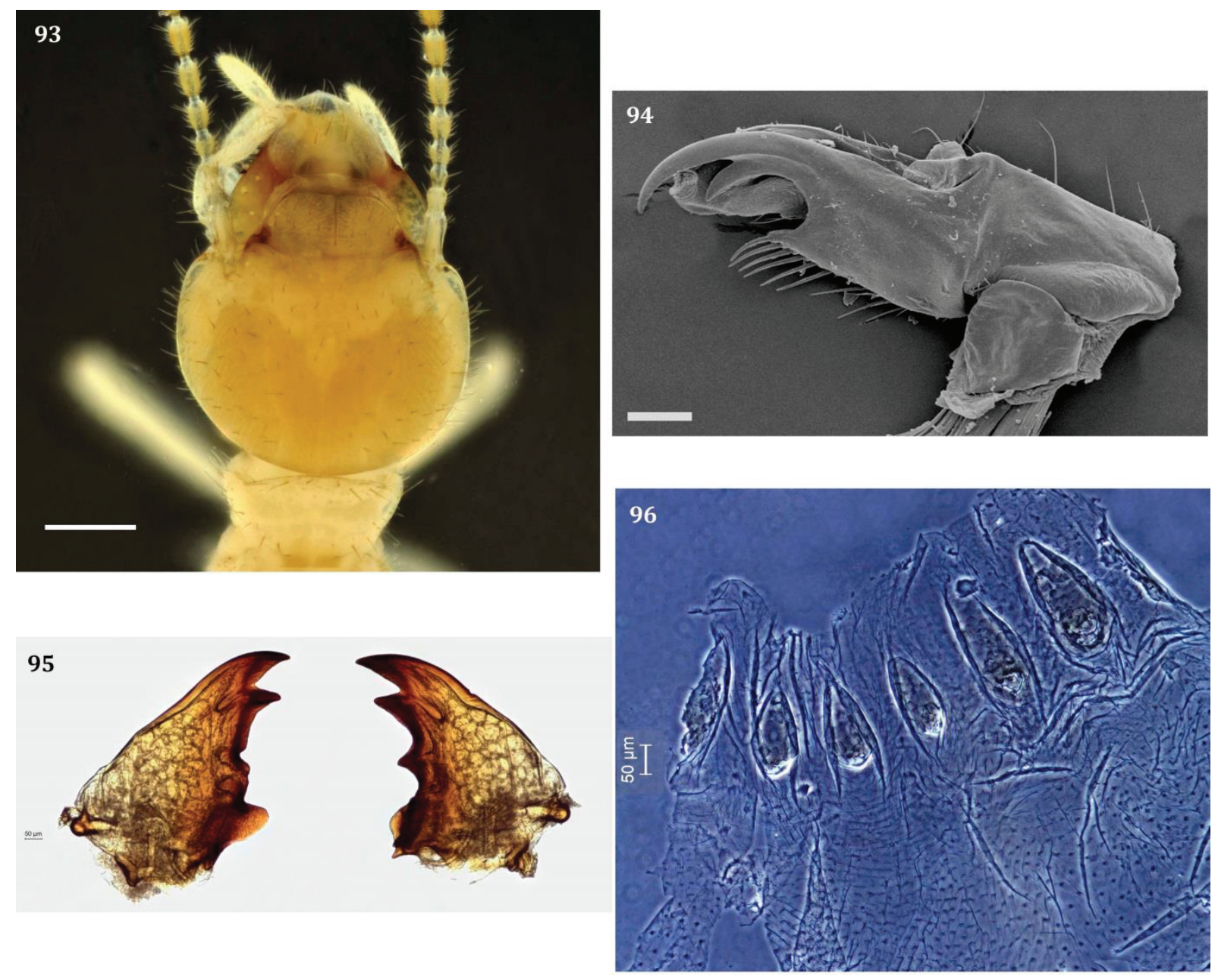

97
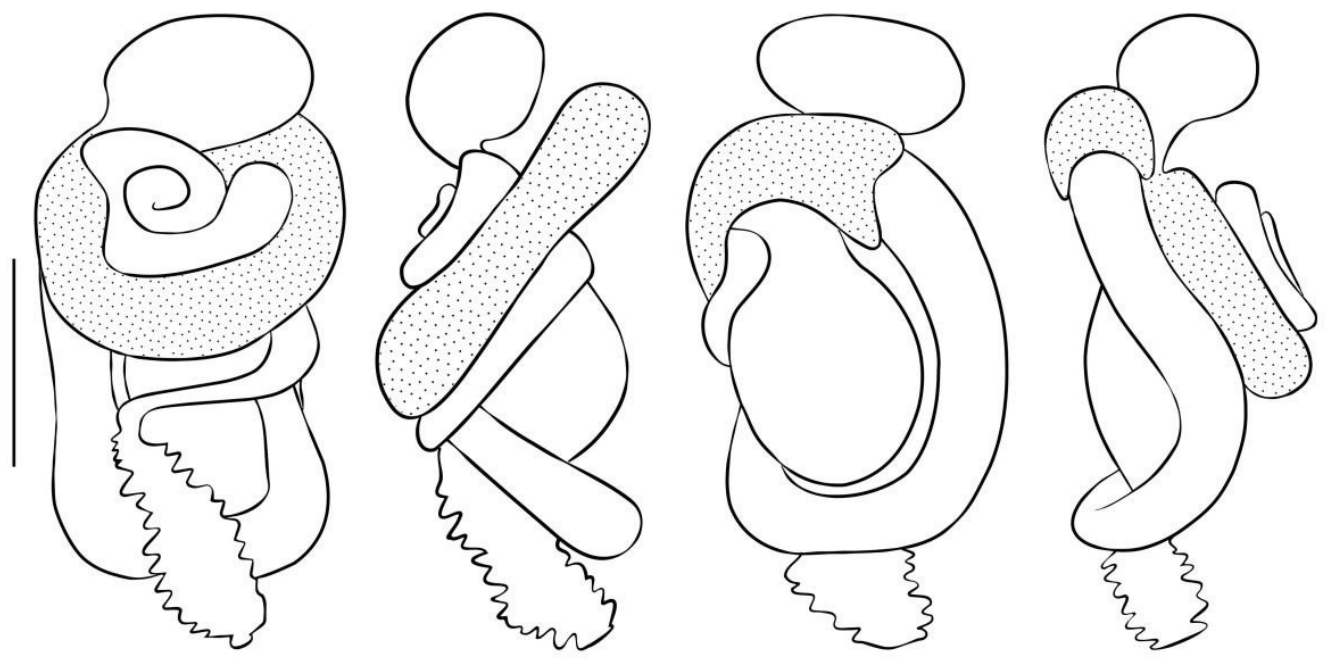

Fig. 93-97. Aparatermes cingulatus. 93- operário em vista dorsal (MZUSP 25542); 94- maxila direita, MEV, escala: 0,1 mm; 95- mandíbula do operário (MZUSP 25542); 96- válvula entérica; 97- esquema de tubo digestório, escala: $1 \mathrm{~mm}$. Escalas: 0,5 mm. 

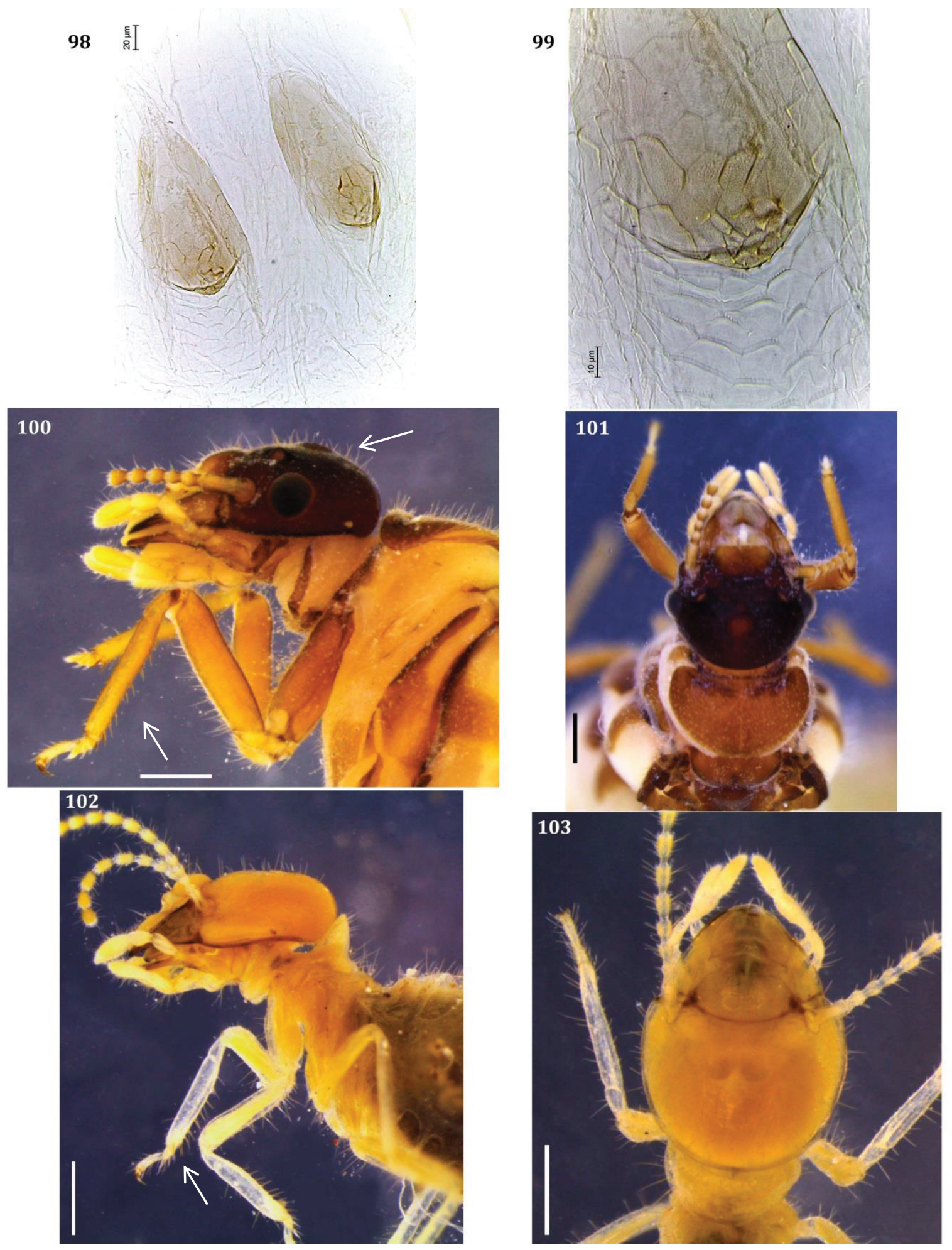

Fig. 98-99. Aparatermes cingulatus (MZUSP 25542). 98- detalhe de duas das pregas da válvula entérica; 99- detalhe da região central de uma prega da válvula entérica. Fig. 100-103. Aparatermes silvestrii (parátipo $\mathrm{CMNH}$ ). 100- rainha primária em vista lateral, a seta indica a fontanela proeminente e a fileira de cerdas grossas na tíbia anterior; 101- rainha primária em vista dorsal; 102- operário em vista lateral, a seta indica a fileira de cerdas grossas na tíbia anterior; 103- operário em vista dorsal. Escalas: 0,5 mm. 

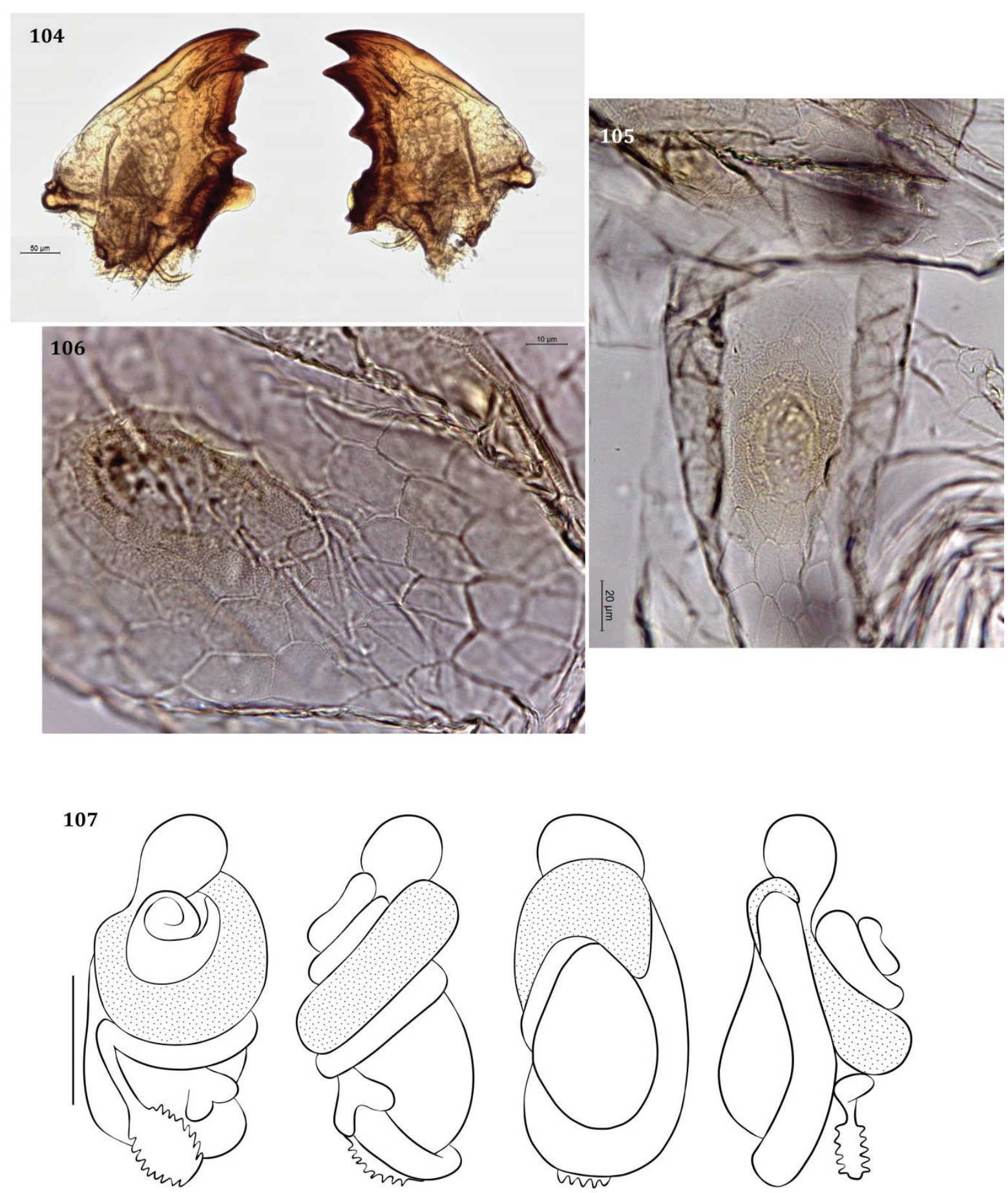

Fig. 104-107. Aparatermes silvestrii (parátipo CMNH).104- mandíbulas do operário; 105- uma das seis pregas da válvula entérica; 106- detalhe da região central da prega; 107- esquema de tubo digestório, escala: $1 \mathrm{~mm}$. 

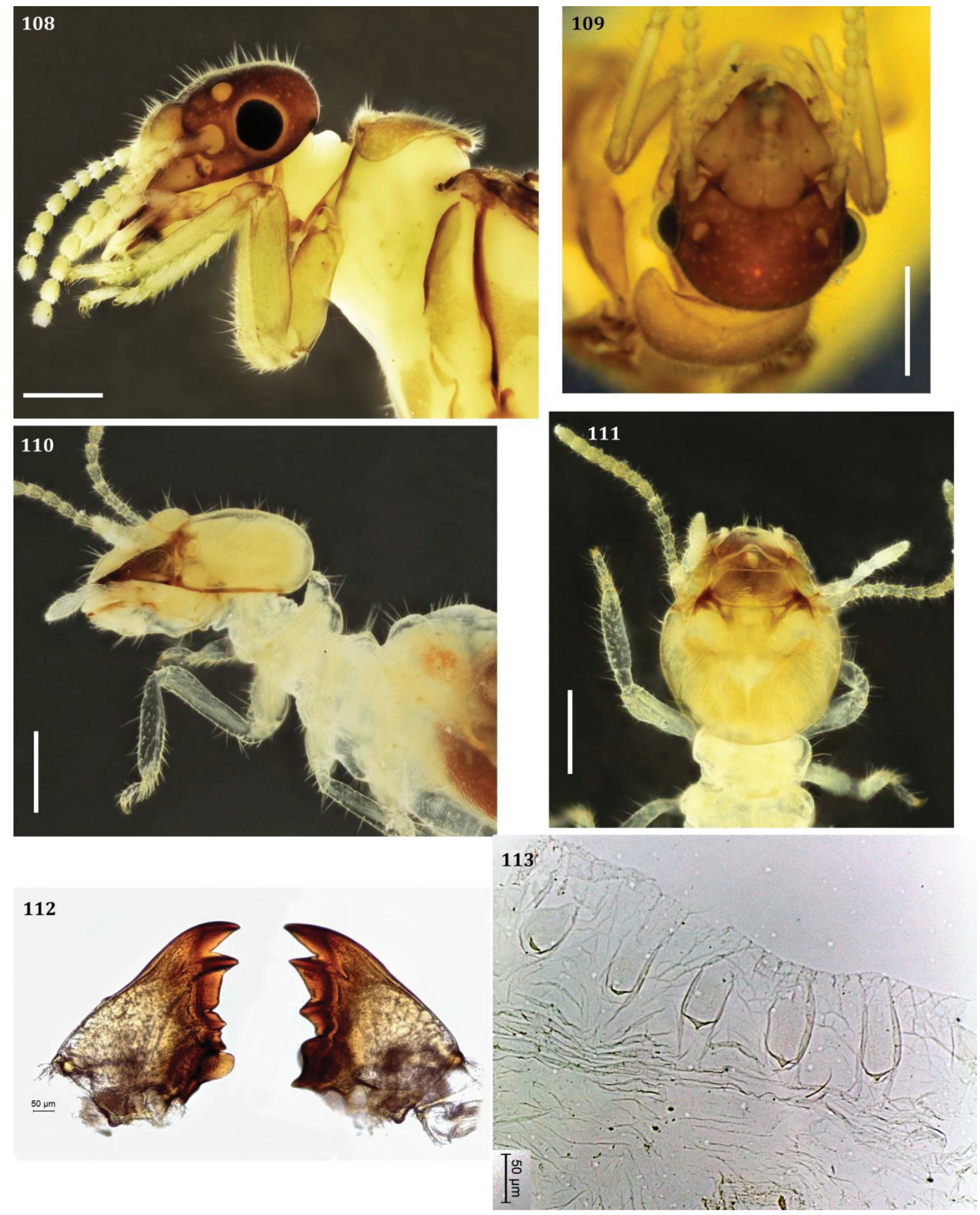

Fig. 108-113. Compositermes vindai (MZUSP 1191). 108- rainha primária em vista lateral; 109rainha primária em vista dorsal; 110- operário em vista lateral; 111- operário em vista dorsal; 112- mandíbulas do operário; 113- válvula entérica. Escalas: 0,5 mm. 

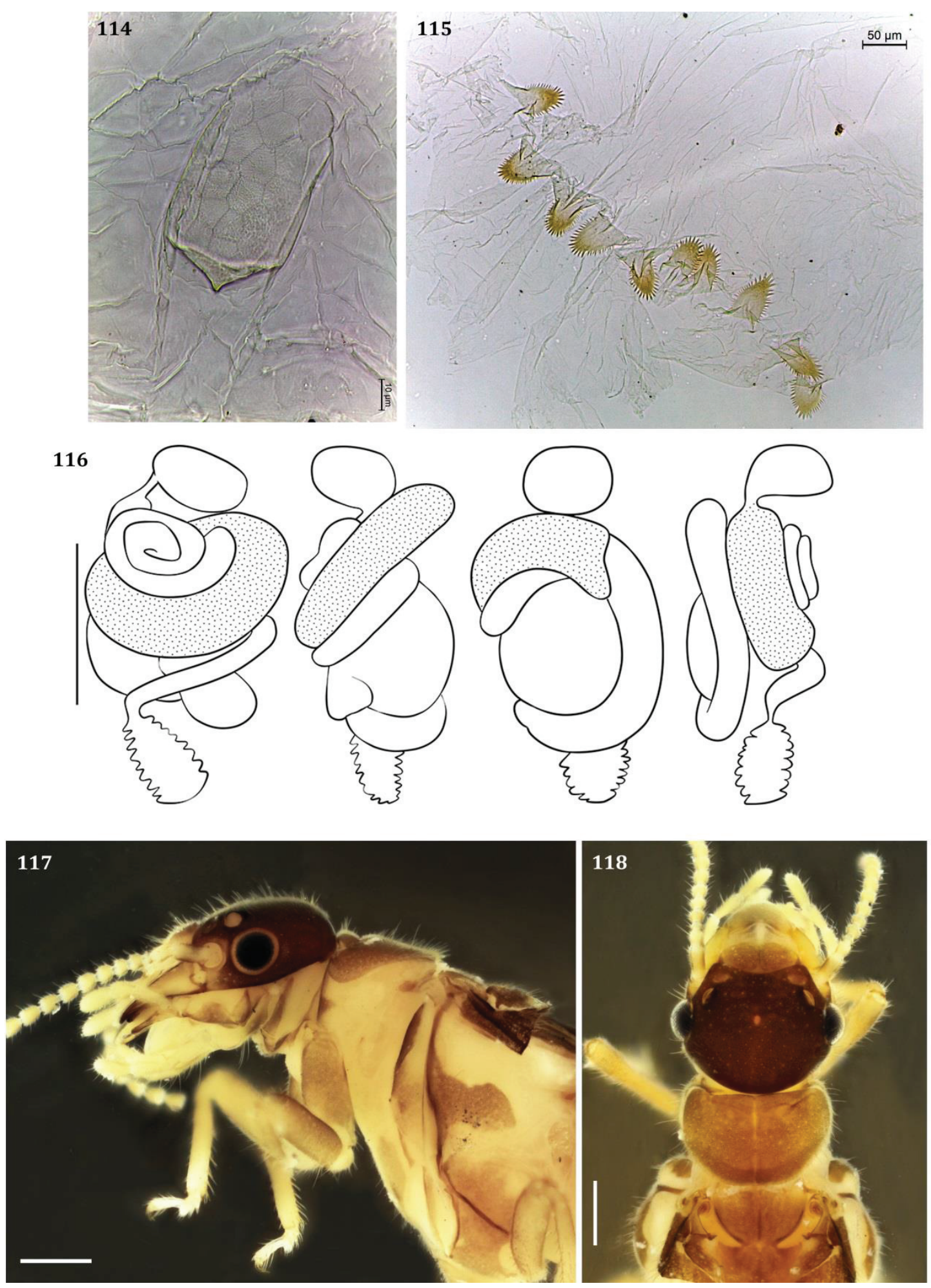

Fig. 114-116. Compositermes vindai (MZUSP 1191). 114- detalhe de uma das pregas da válvula entérica; 115- anel de placas pectinadas localizadas na região final do assentamento da válvula entérica; 116- esquema de tubo digestório, escala: $1 \mathrm{~mm}$. Fig. 117-118. Disjunctitermes sp. 1 (MZUSP 22694). 117- alado em vista lateral; 118-alado em vista dorsal. Escalas: 0,5 mm. 

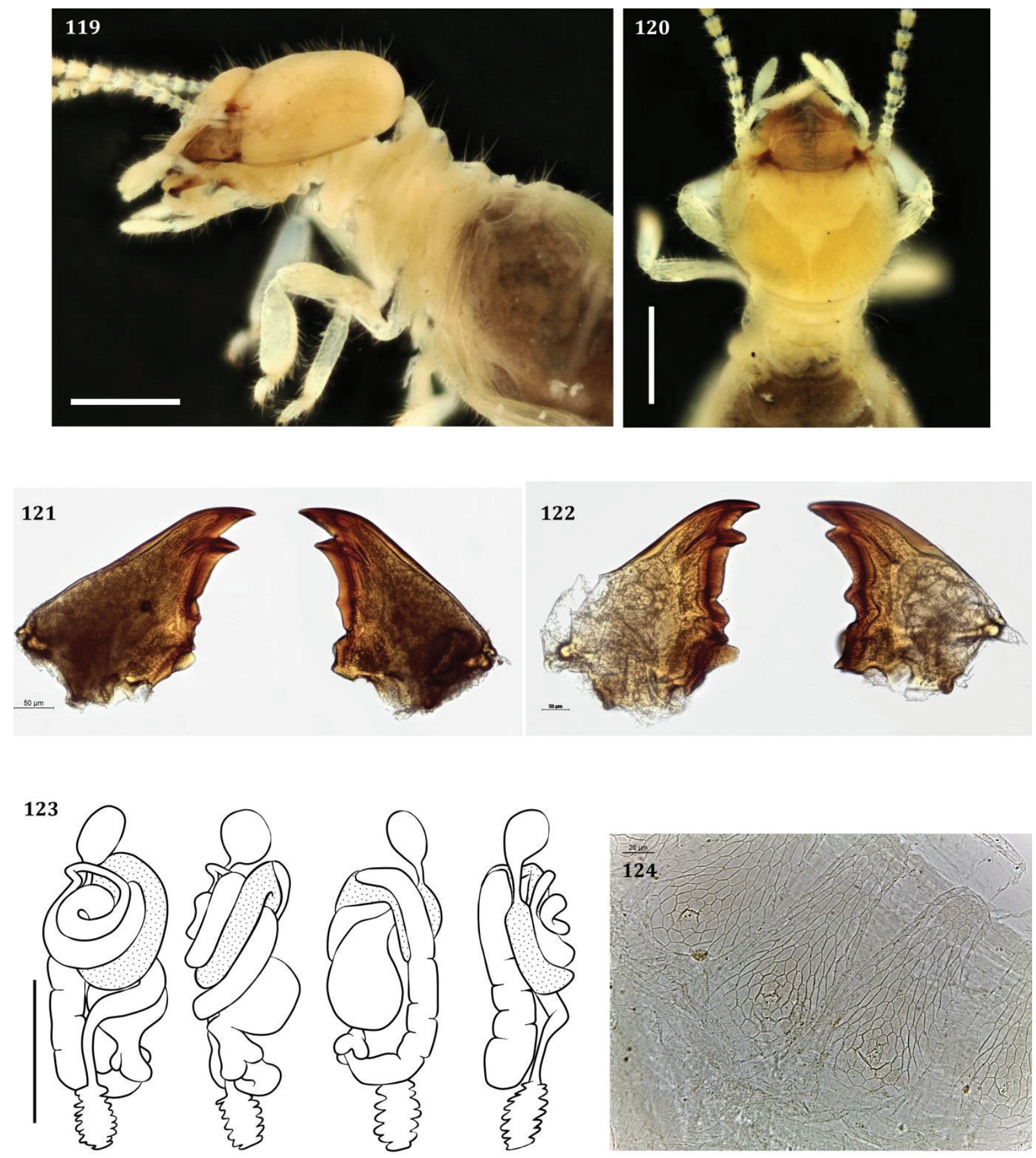

Fig. 119-124. Disjunctitermes sp. 1 (MZUSP 22694). 119- operário em vista lateral; 120-operário em vista dorsal; 121- mandíbulas do alado; 122- mandíbulas do operário; 123- esquema de tubo digestório, escala: $1 \mathrm{~mm}$; 124- detalhe da válvula entérica mostrando duas das seis pregas. Escalas: $0,5 \mathrm{~mm}$. 

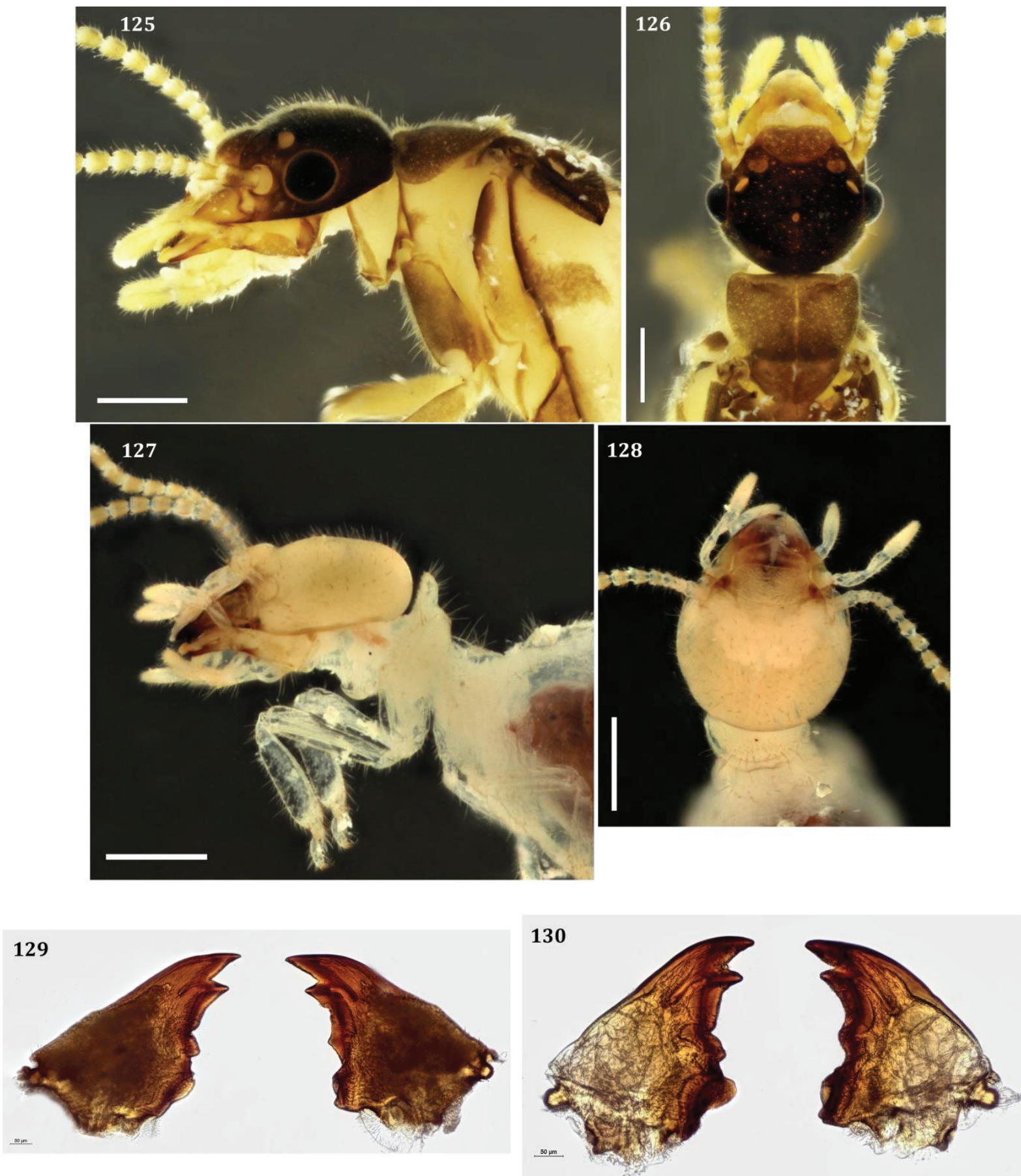

Fig. 125-130. Disjunctitermes sp. 2 (MZUSP 26702). 125- alado em vista lateral; 126- alado em vista dorsal; 127 - operário em vista lateral; 128- operário em vista dorsal; 129 - mandíbulas do alado; 130- mandíbulas do operário. Escalas: 0,5mm. 

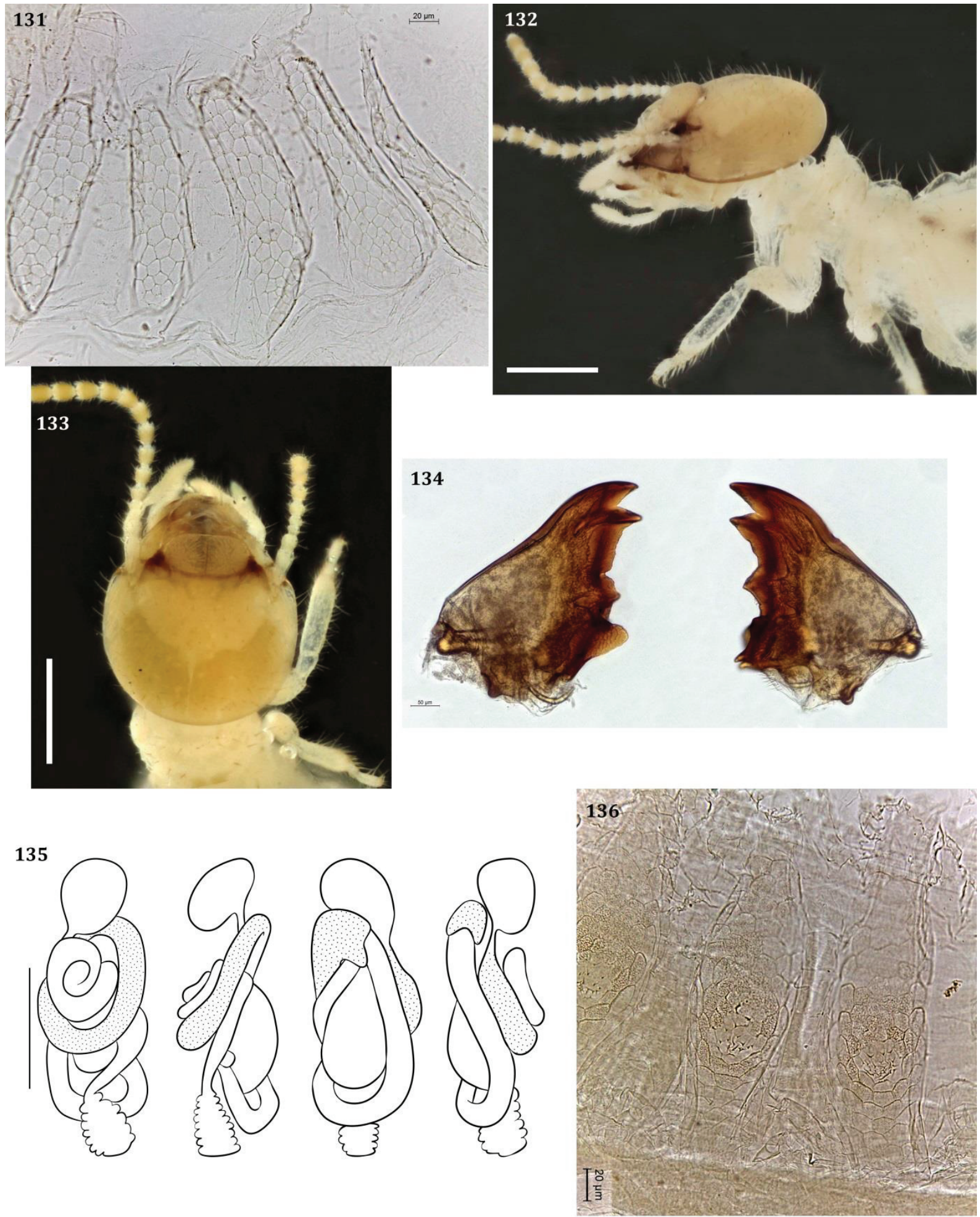

Fig. 131. Disjunctitermes sp. 2 (MZUSP 26702), válvula entérica. Fig. 132-136. Gênero 1 sp. ES2 (MZUSP 13704). 132- operário em vista lateral; 133- operário em vista dorsal; 134- mandíbulas do operário; 135- esquema de tubo digestório, escala: $1 \mathrm{~mm}$; 136- detalhe de duas das seis pregas da válvula entérica. Escalas: 0,5mm. 

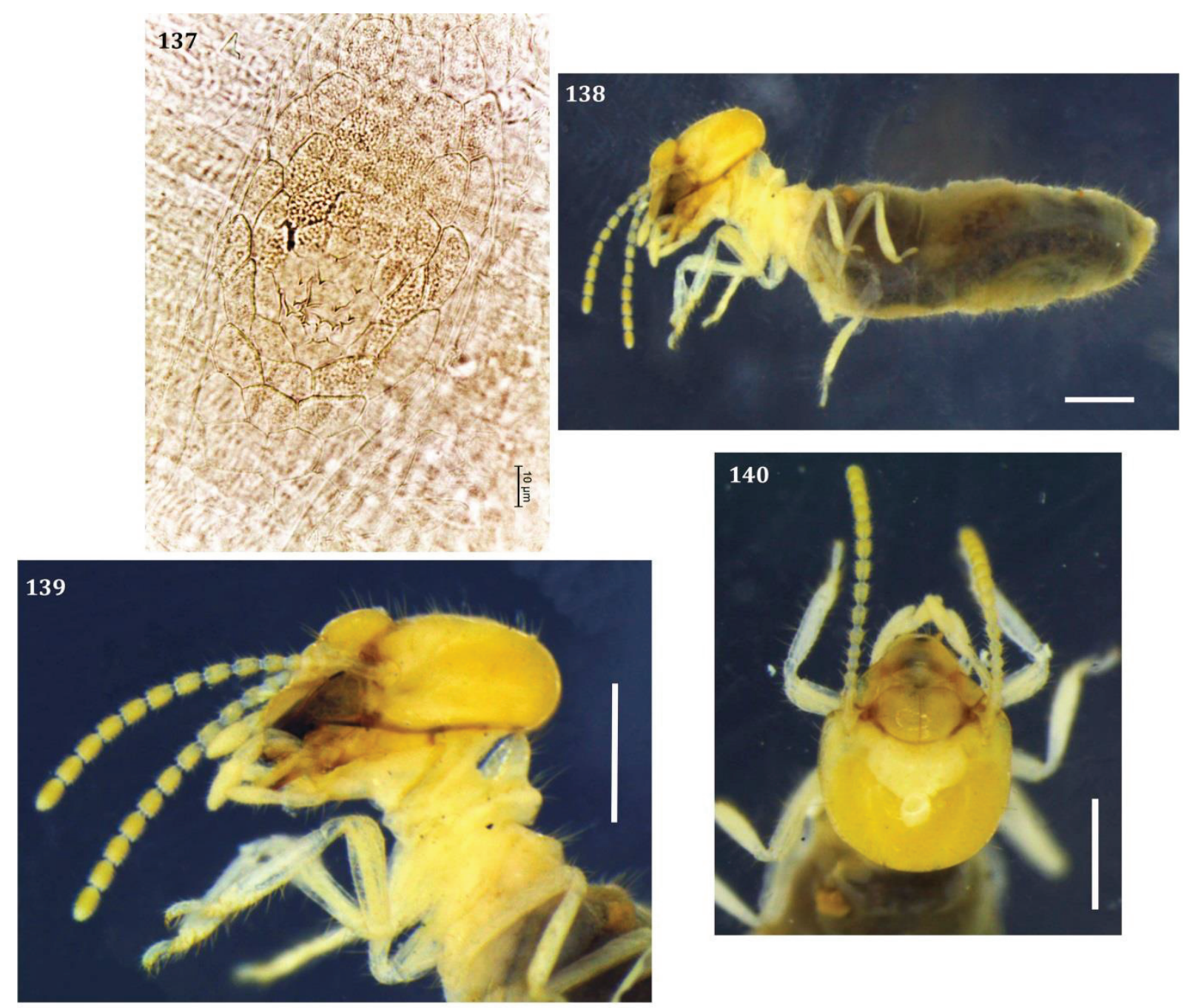

141
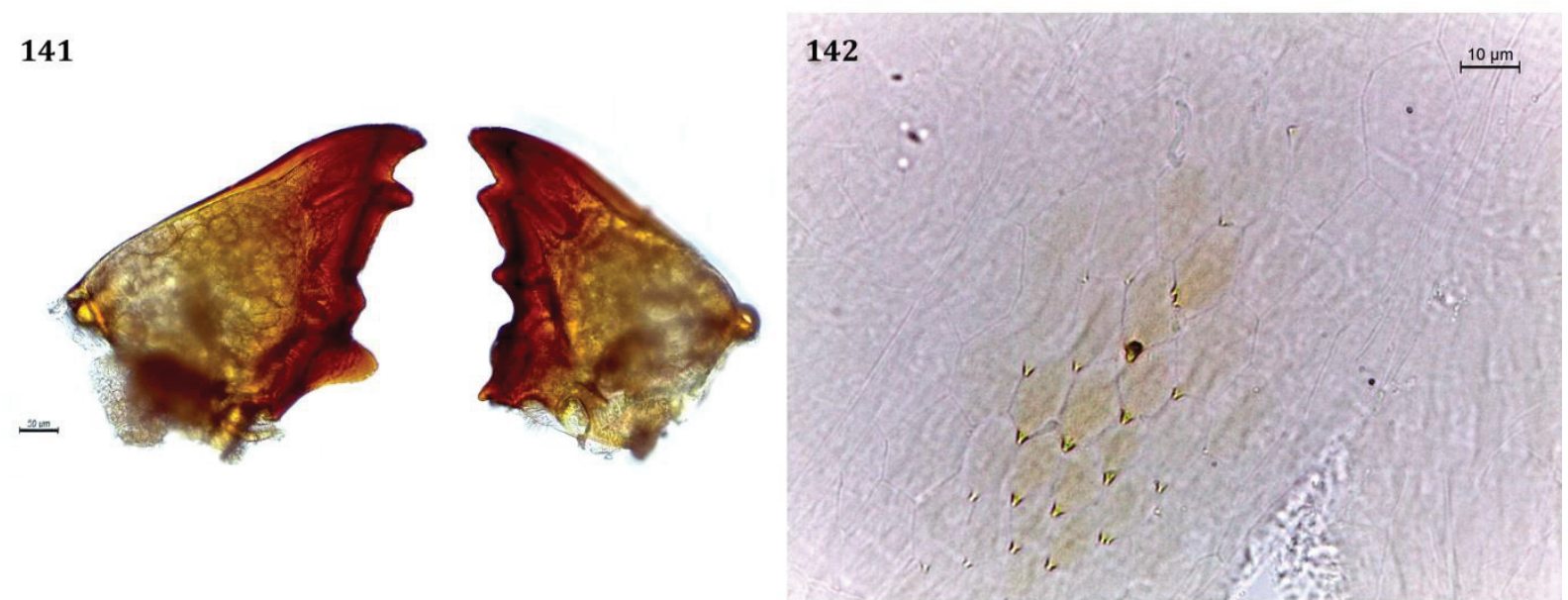

Fig. 137. Gênero 1 sp. ES2 (MZUSP 13704), detalhe da porção proximal da válvula entérica. Fig. 138-142. Gênero 1 sp. S5(MZUSP 26910). 138- hábito do operário; 139-operário em vista lateral; 140- operário em vista dorsal; 141- mandíbulas do operário; 142- detalhe de uma das pregas da válvula entérica. Escalas: 0,5mm. 

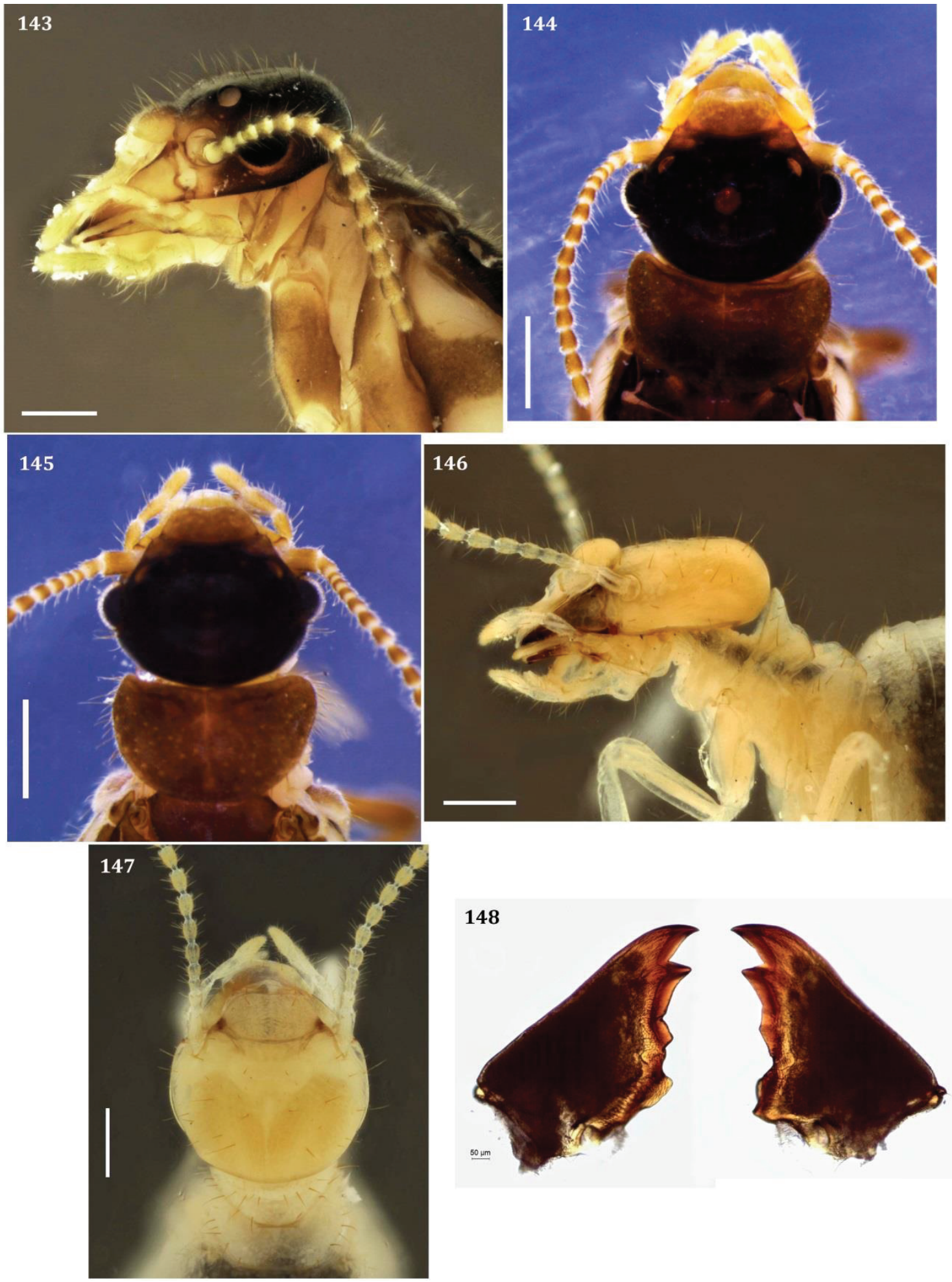

Fig. 143-148. Gênero 2 sp. MCH (MZUSP 25872). 143- alado em vista lateral; 144-fêmea alada em vista dorsal; 145- macho alado em vista dorsal; 146- operário em vista lateral; 147- operário em vista dorsal; 148- mandíbulas do alado. Escalas: 0,5mm. 

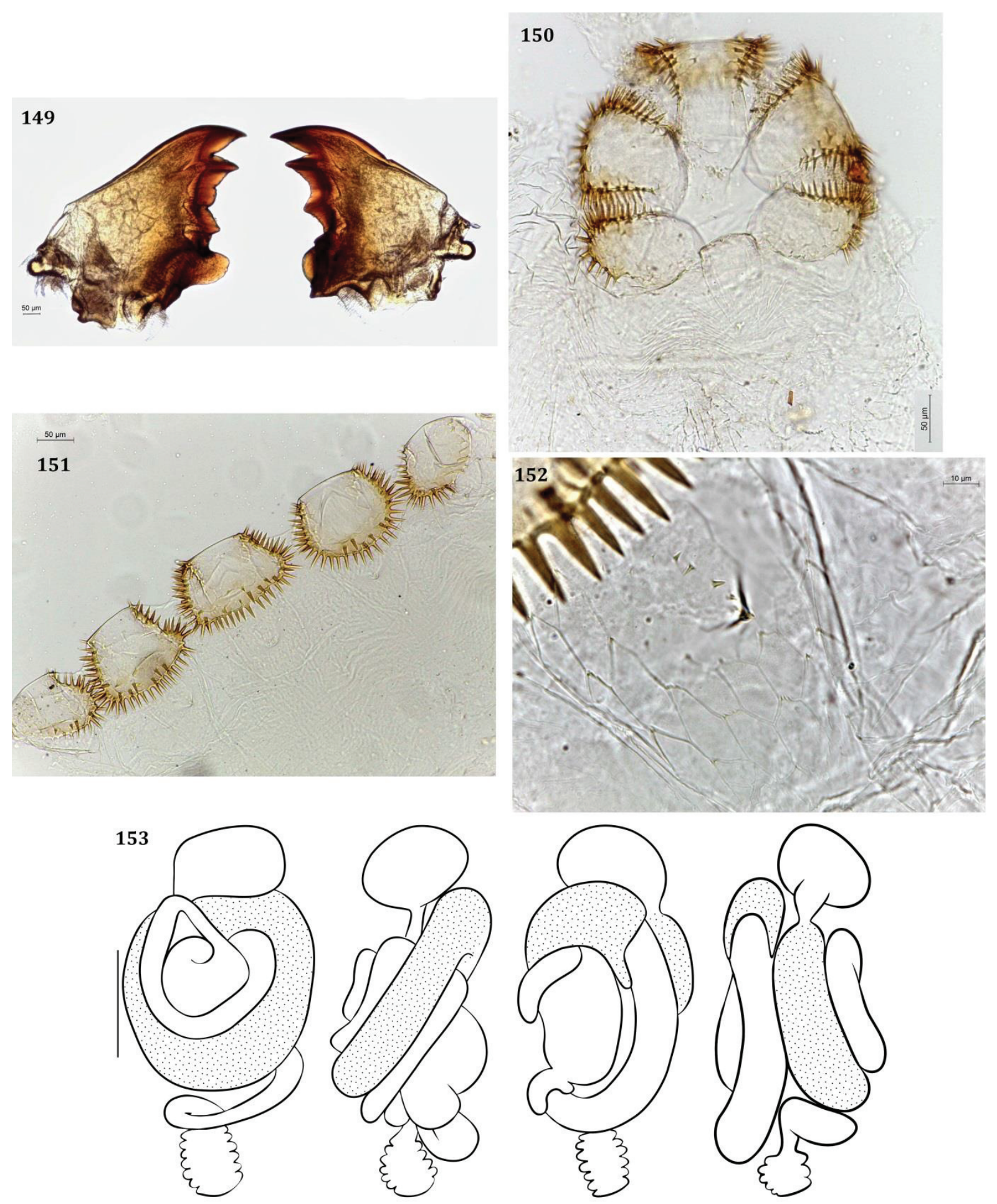

Fig. 149-153. Gênero 2 sp. MCH (MZUSP 25872). 149- mandíbulas do operário; 150- porção armada da válvula entérica in situ; 151- válvula entérica montada, a sexta placa é reduzida; 152detalhe de uma das seis pregas da válvula entérica; 153- esquema de tubo digestório, escala: 1 $\mathrm{mm}$. 


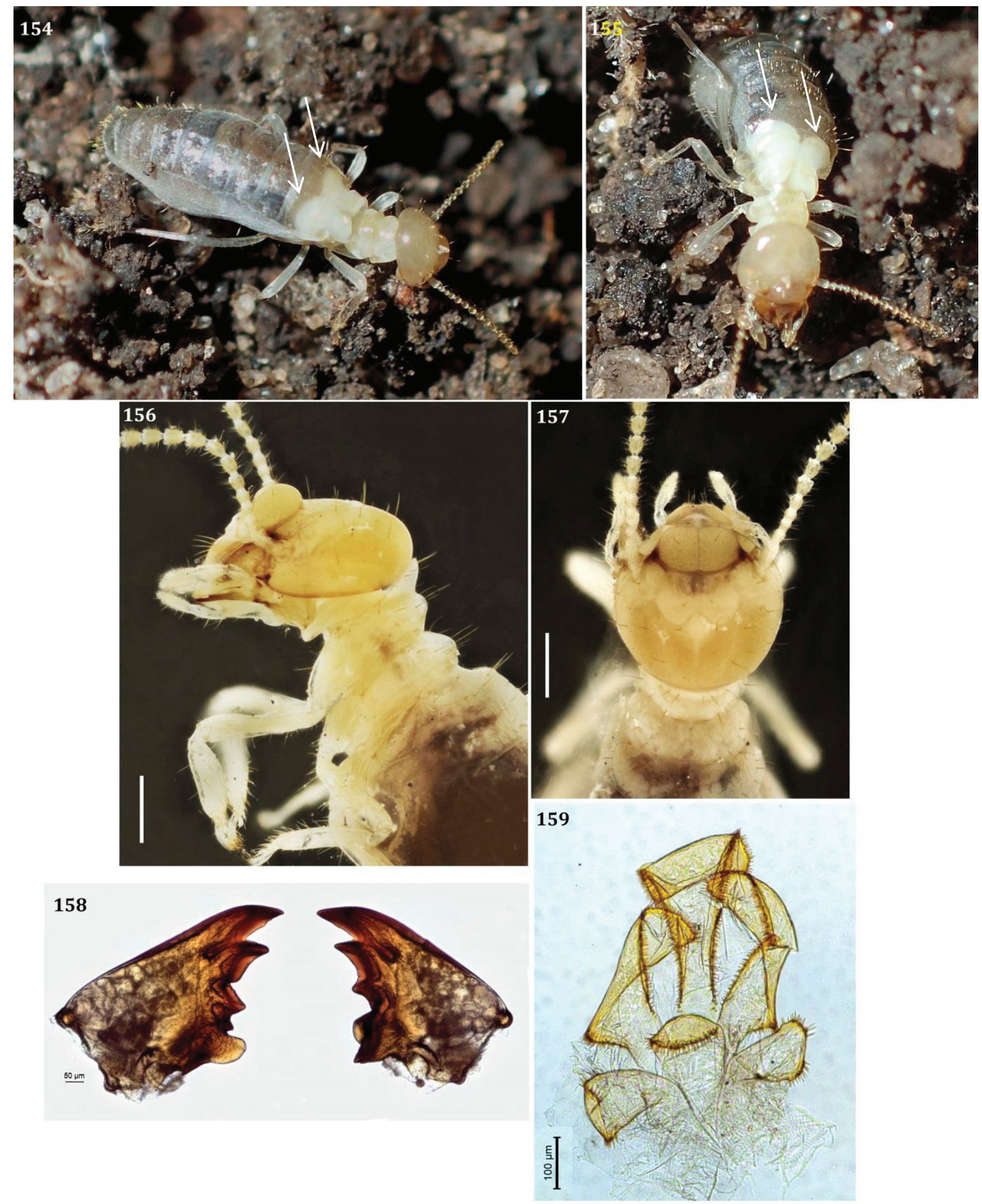

Fig. 154-155. Gênero 2 sp. MCH (MZUSP 25872) imagens no campo, as setas indicam os órgãos deiscentes. Fig. 156-159. Gênero 3 sp. ORQ (MZUSP 25141). 156- operário em vista lateral; 157 operário em vista dorsal; 158- mandíbulas do operário; 159- porção armada da válvula entérica in situ. Escalas: 0,5 mm. 

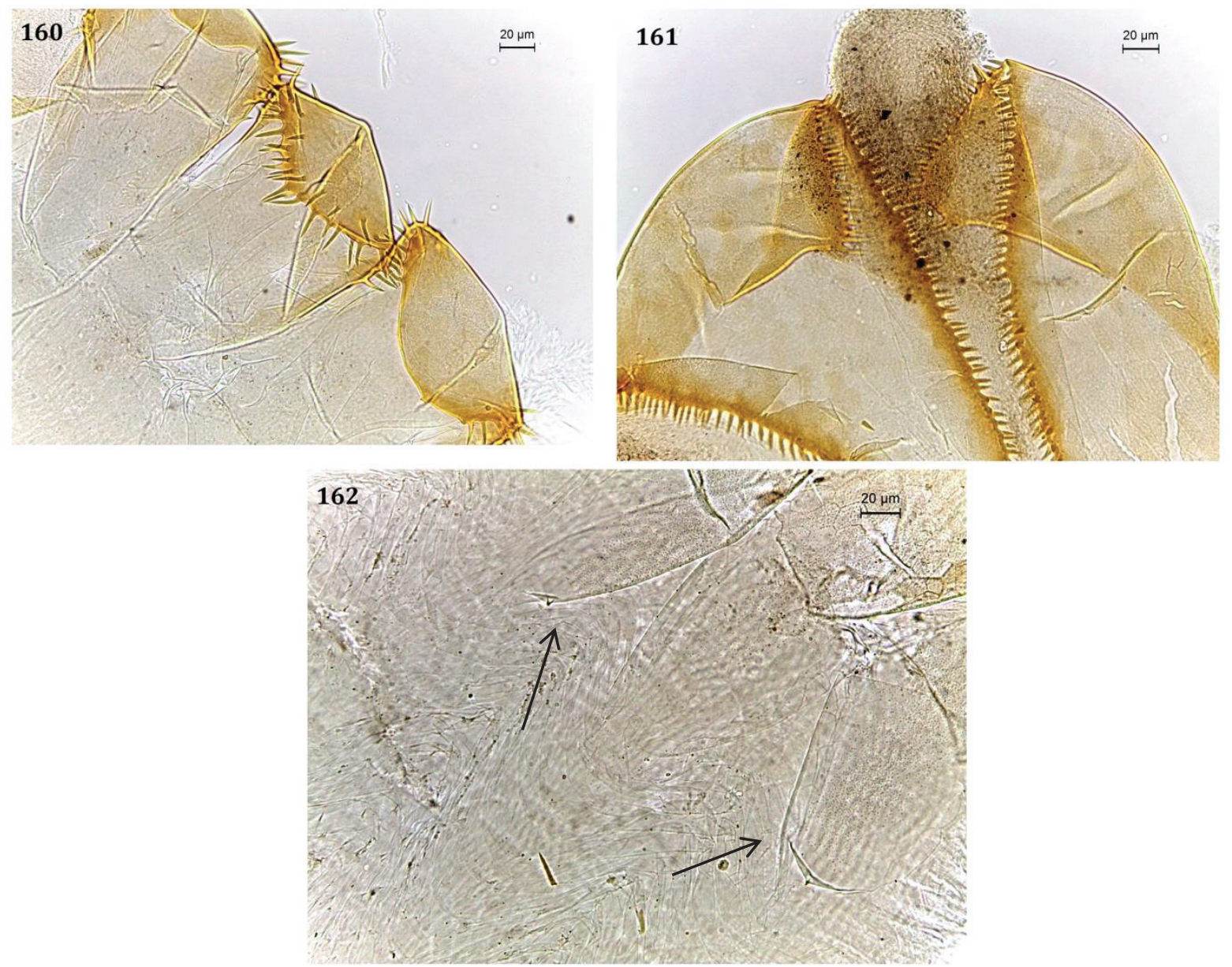

163
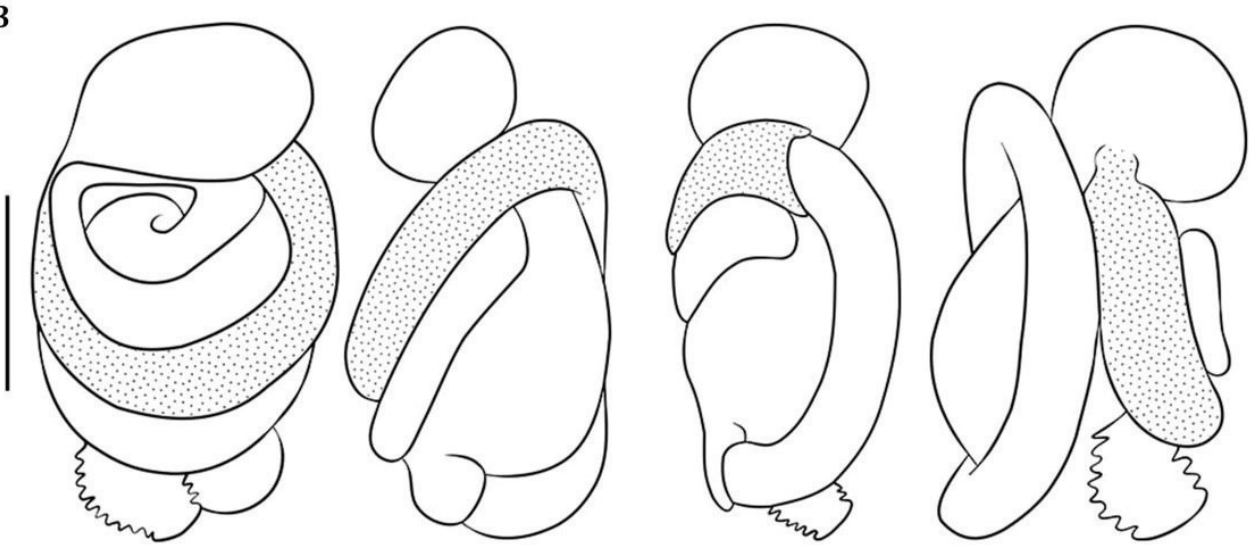

Fig. 160-163. Gênero 3 sp. ORQ (MZUSP 25141). 160- detalhe das placas menores da válvula entérica; 161- detalhe das placas maiores da válvula entérica; 162- detalhe de três das seis pregas da válvula entérica; 163- esquema de tubo digestório, escala: $1 \mathrm{~mm}$. 

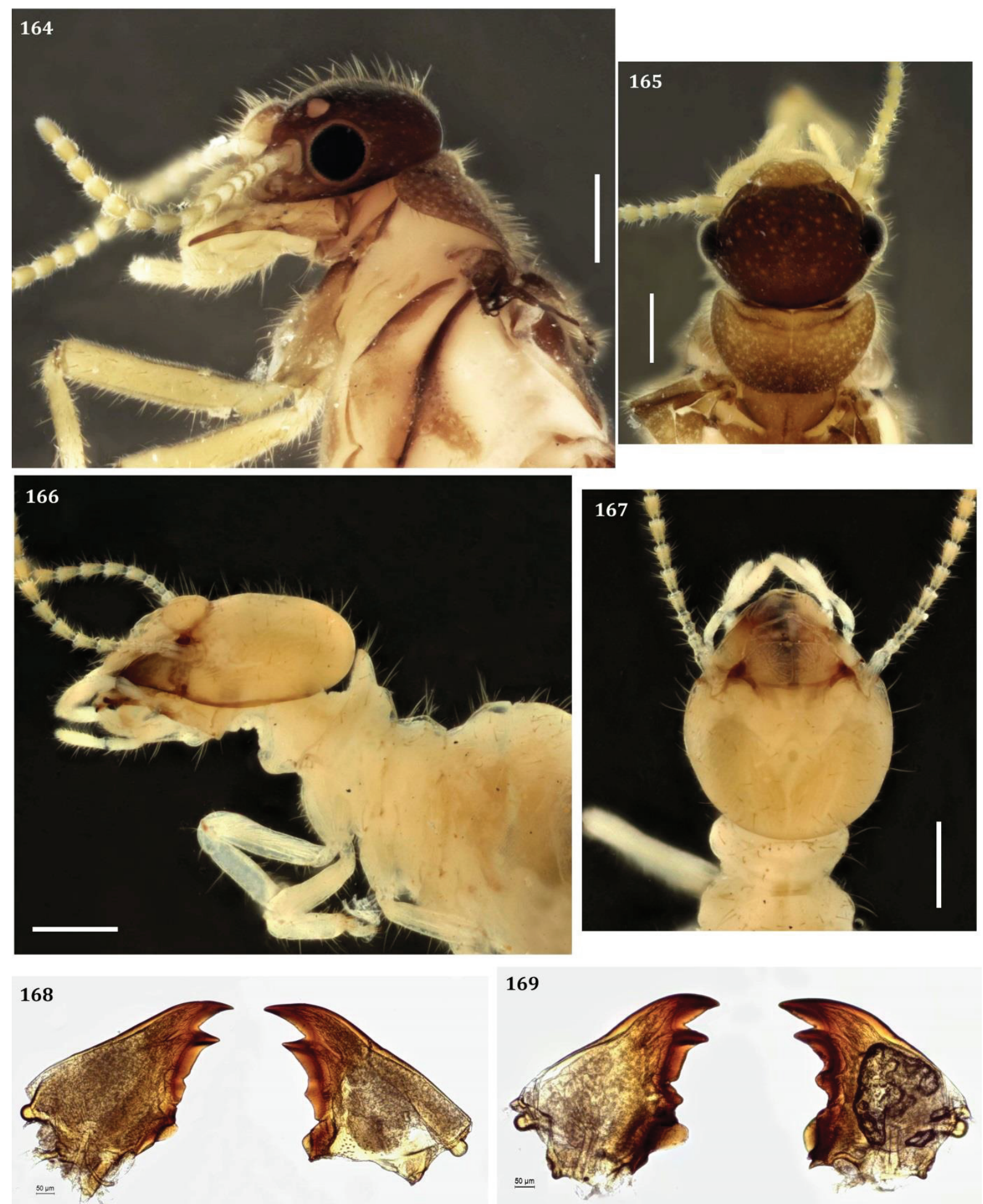

Fig. 164-169. Gênero 4 sp. V1 (MZUSP 22689). 164- alado em vista lateral; 165- alado em vista dorsal; 166- operário em vista lateral; 167- operário em vista dorsal; 168- mandíbulas do alado; 169- mandíbulas do operário. Escalas: 0,5 mm. 

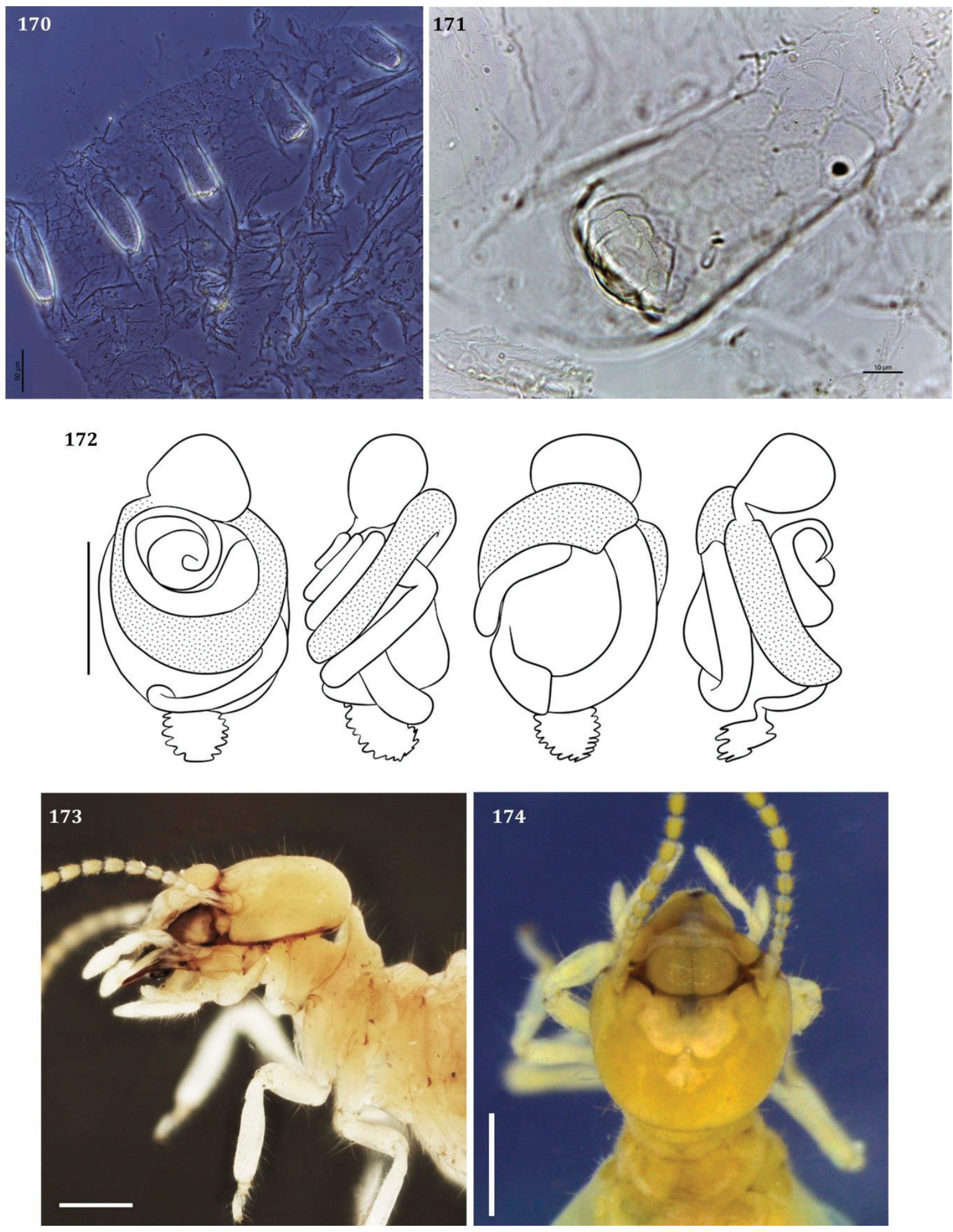

Fig. 170-172. Gênero 4 sp. V1 (MZUSP 22689). 170- válvula entérica com cinco das seis pregas visíveis; 171 - detalhe de uma das pregas da válvula entérica; 172- esquema de tubo digestório, escala: $1 \mathrm{~mm}$. Fig. 173-174. Gênero $5 \mathrm{sp}$. V4 (MZUSP 11038). 173- operário em vista lateral; 174- operário em vista dorsal. Escalas: 0,5mm. 

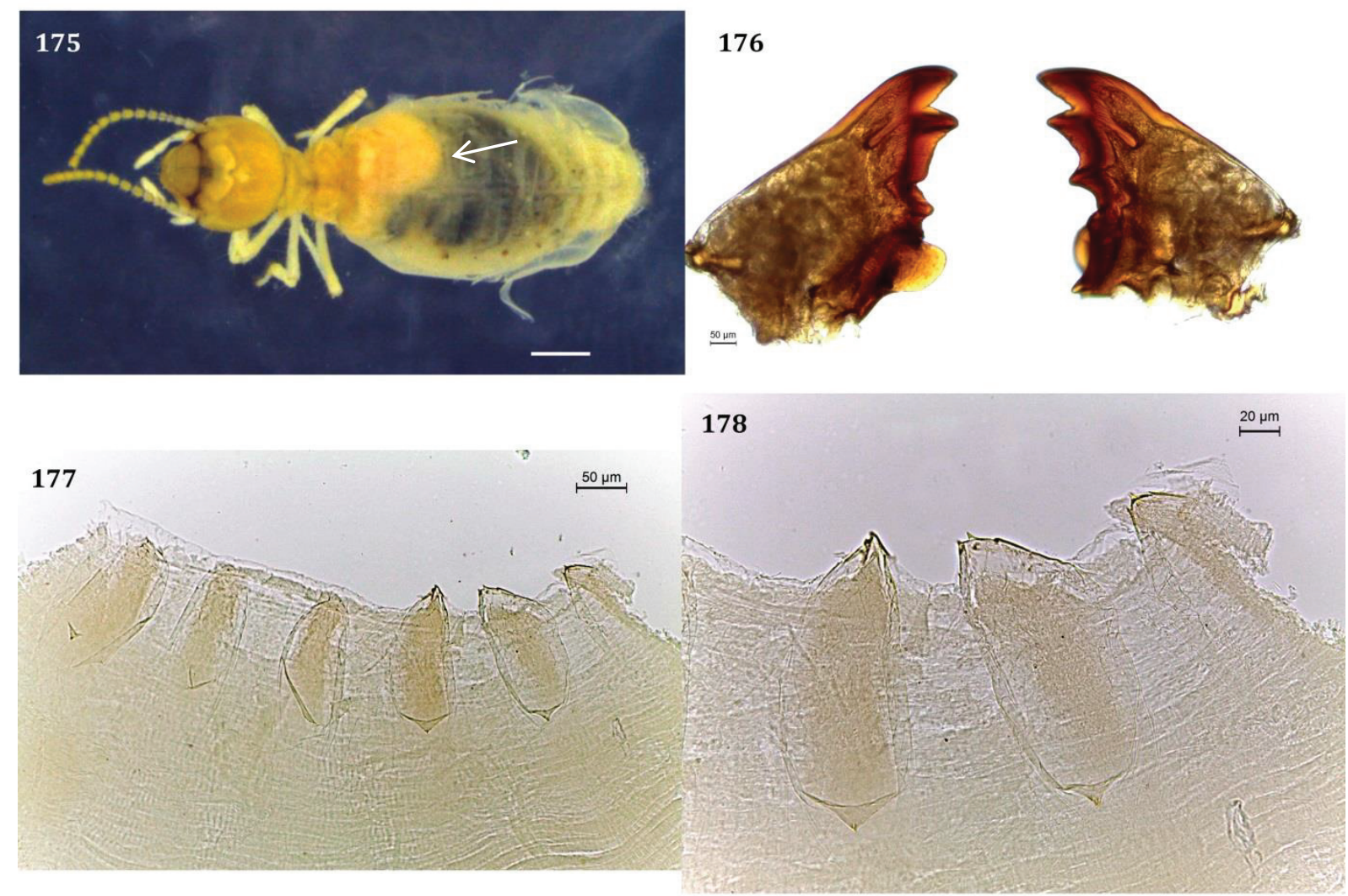

179

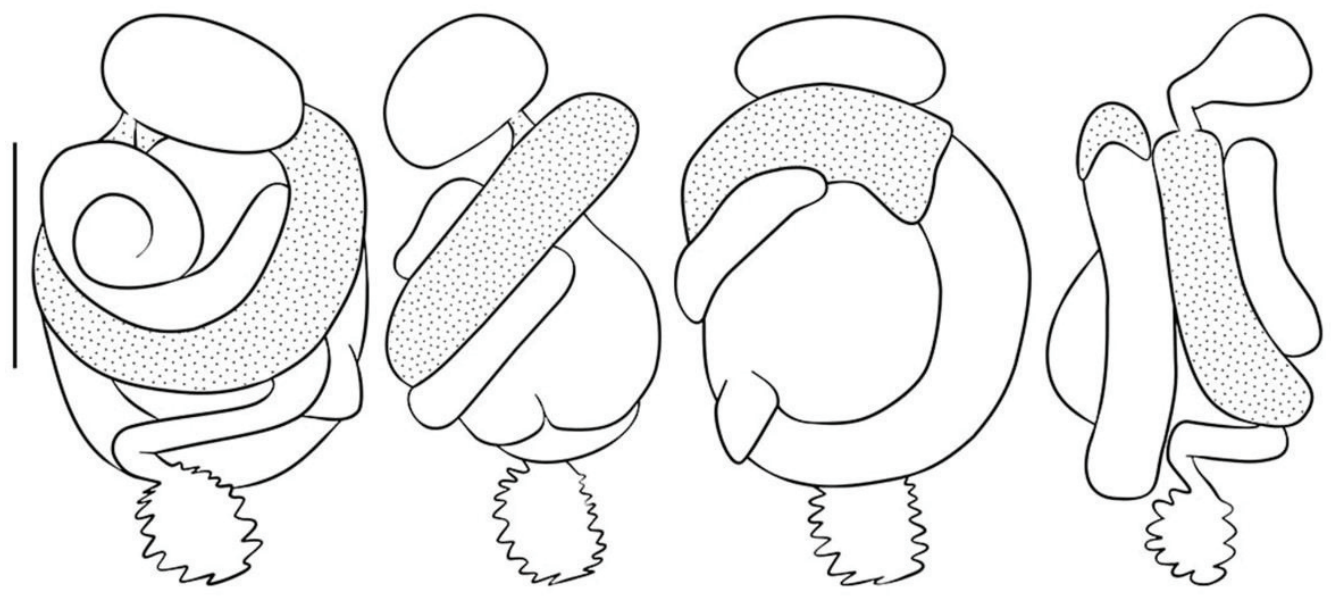

Fig. 175-179. Gênero 5 sp. V4 (MZUSP 11038). 175- hábito do operário, seta indica órgão deiscente; 176- mandíbulas do operário, seta indica órgão deiscente; 177- válvula entérica; 178detalhe de três das pregas da válvula entérica; 179- esquema de tubo digestório, escala: $1 \mathrm{~mm}$. 

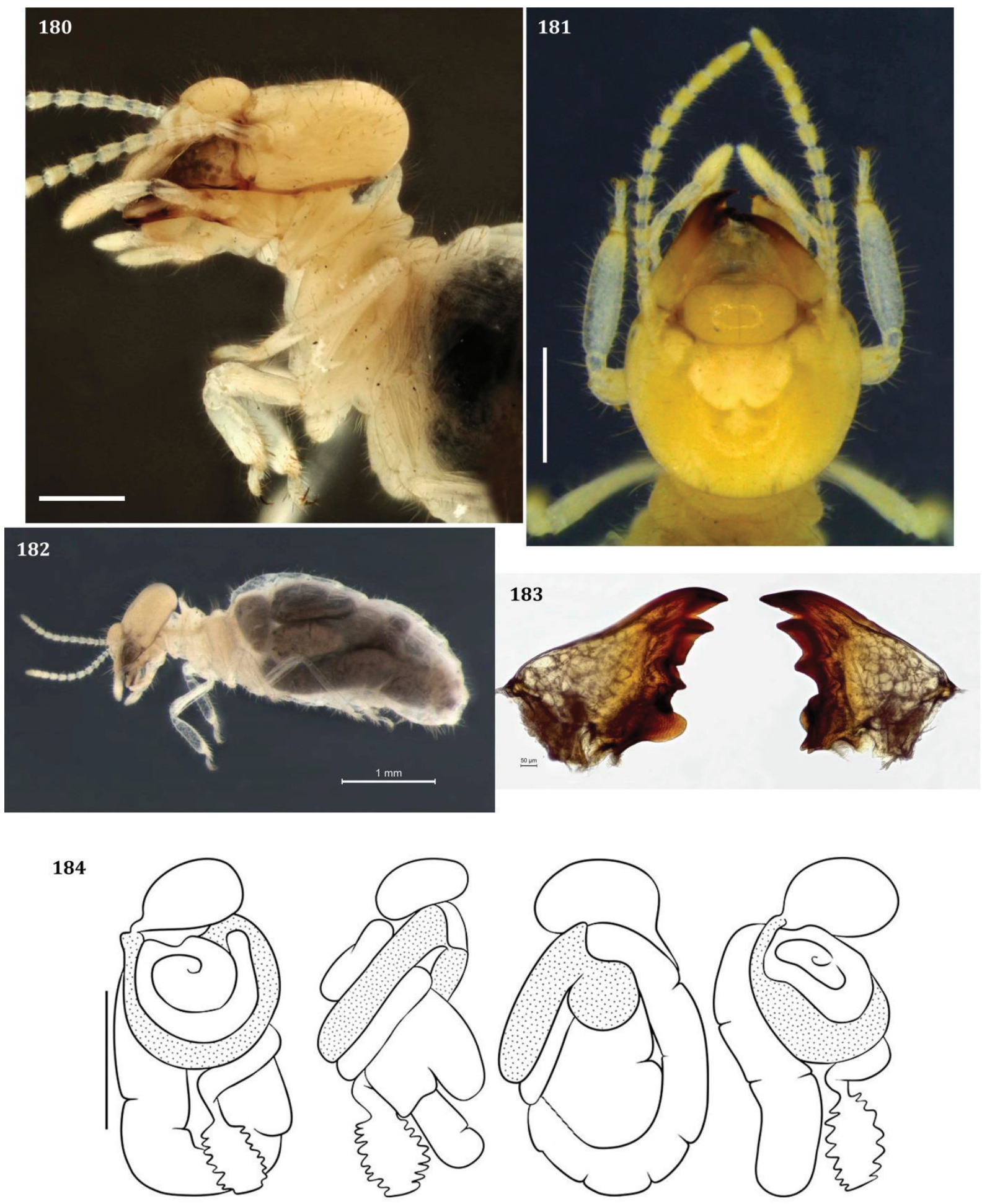

Fig. 180-184. Gênero 6 sp. S8 (MZUSP 25621). 180- operário em vista lateral; 181- operário em vista dorsal; 182- hábito do operário; 183- mandíbulas do operário; 184- esquema de tubo digestório, escala: $1 \mathrm{~mm}$. Escalas: 0,5 $\mathrm{mm}$. 

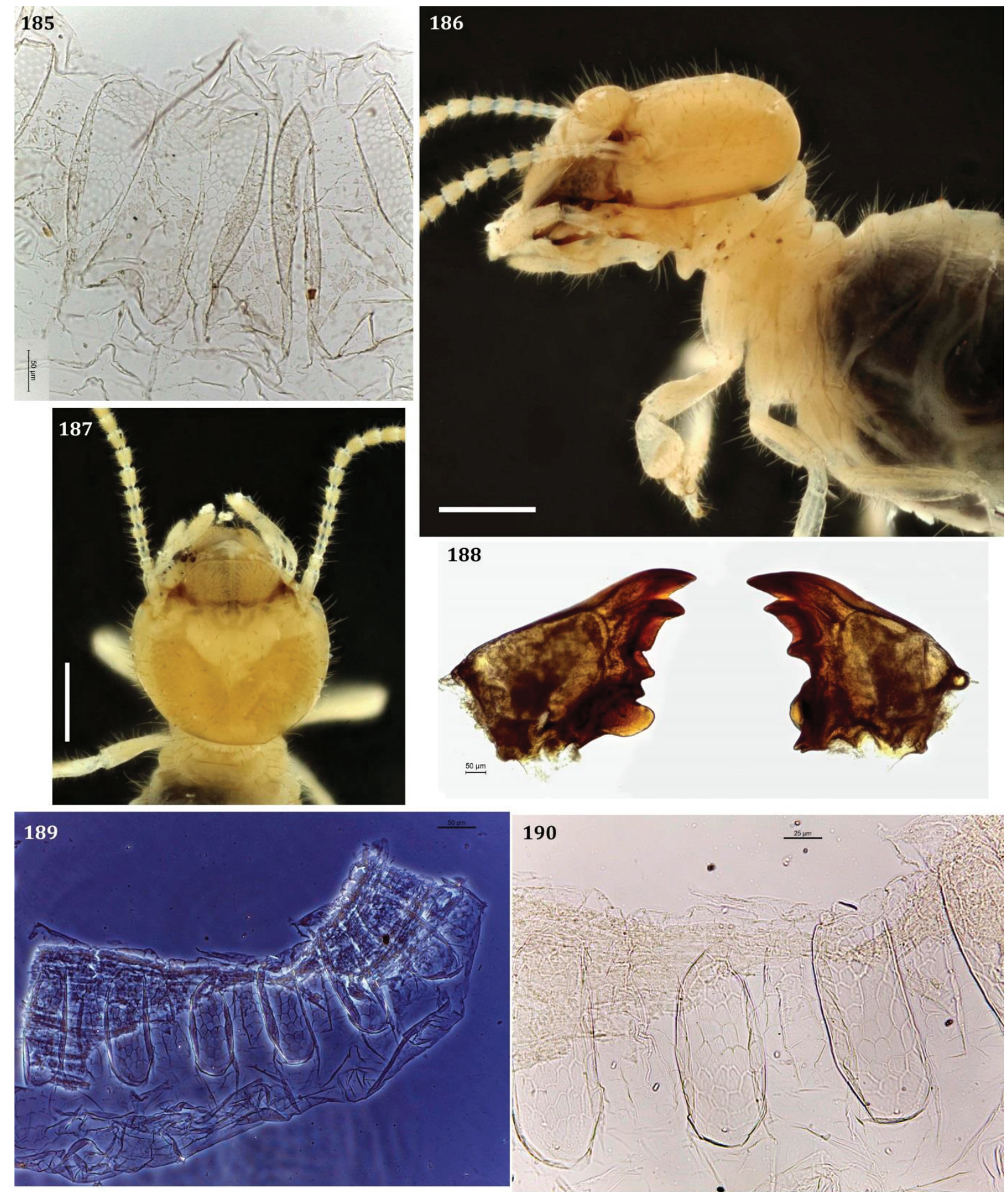

Fig. 185. Gênero 6 sp. S8 (MZUSP 25621), detalhe da válvula entérica. Fig. 186-190. Gênero 7 sp. S7 (MZUSP 25648). 186-operário em vista lateral; 187- operário em vista dorsal; 188mandíbulas do operário; 189- válvula entérica; 190- detalhe da válvula entérica com três das seis pregas visíveis. Escalas: 0,5 mm. 
191
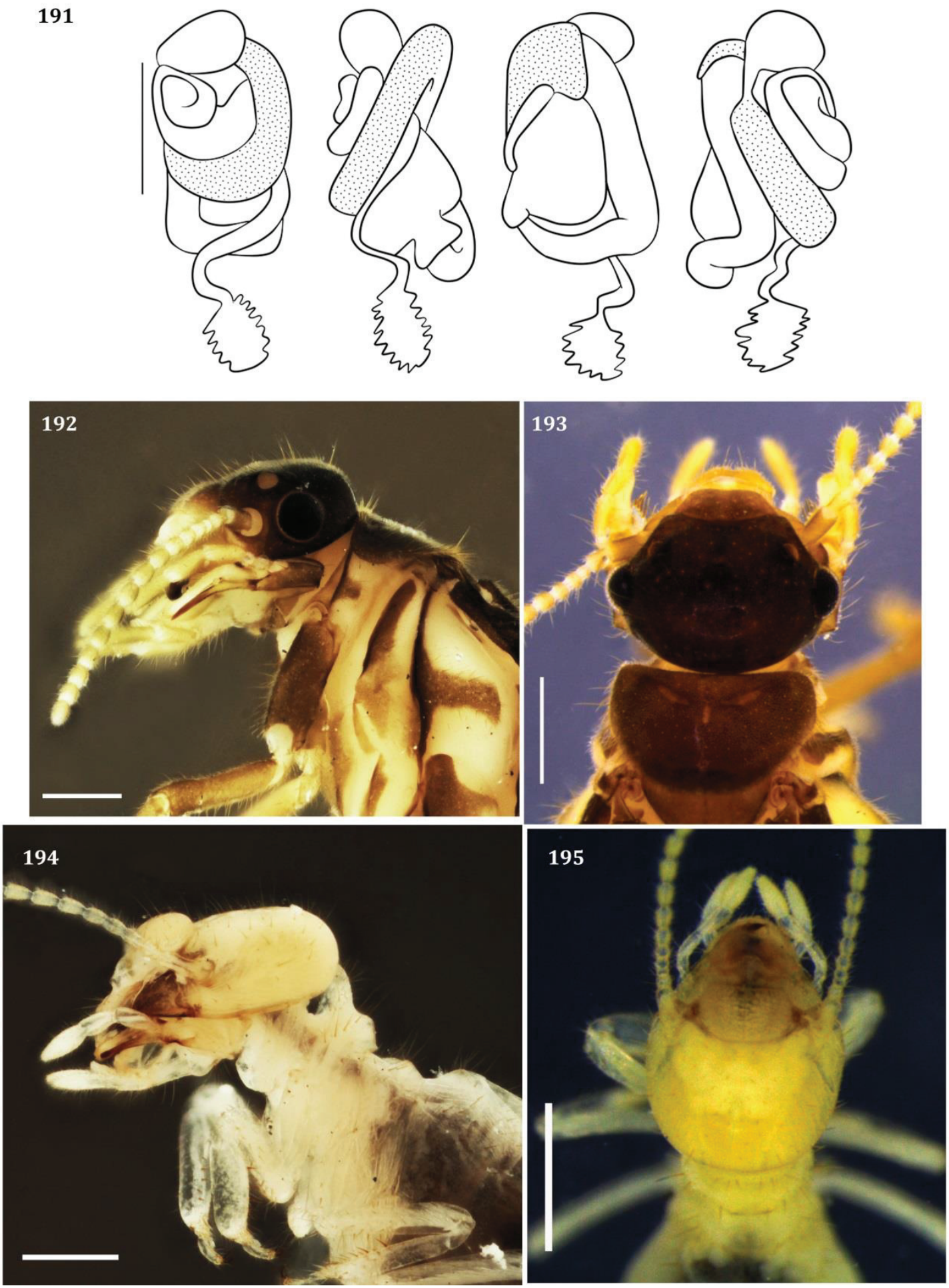

Fig. 191. Gênero 7 sp. S7 (MZUSP 11040), esquema de tubo digestório, escala: 1 mm. Fig. 192195. Gênero 8 sp. S3 (MZUSP 26676). 192- alado em vista lateral; 193- alado em vista dorsal; 194- operário em vista lateral; 195- operário em vista dorsal. Escalas: 0,5mm. 

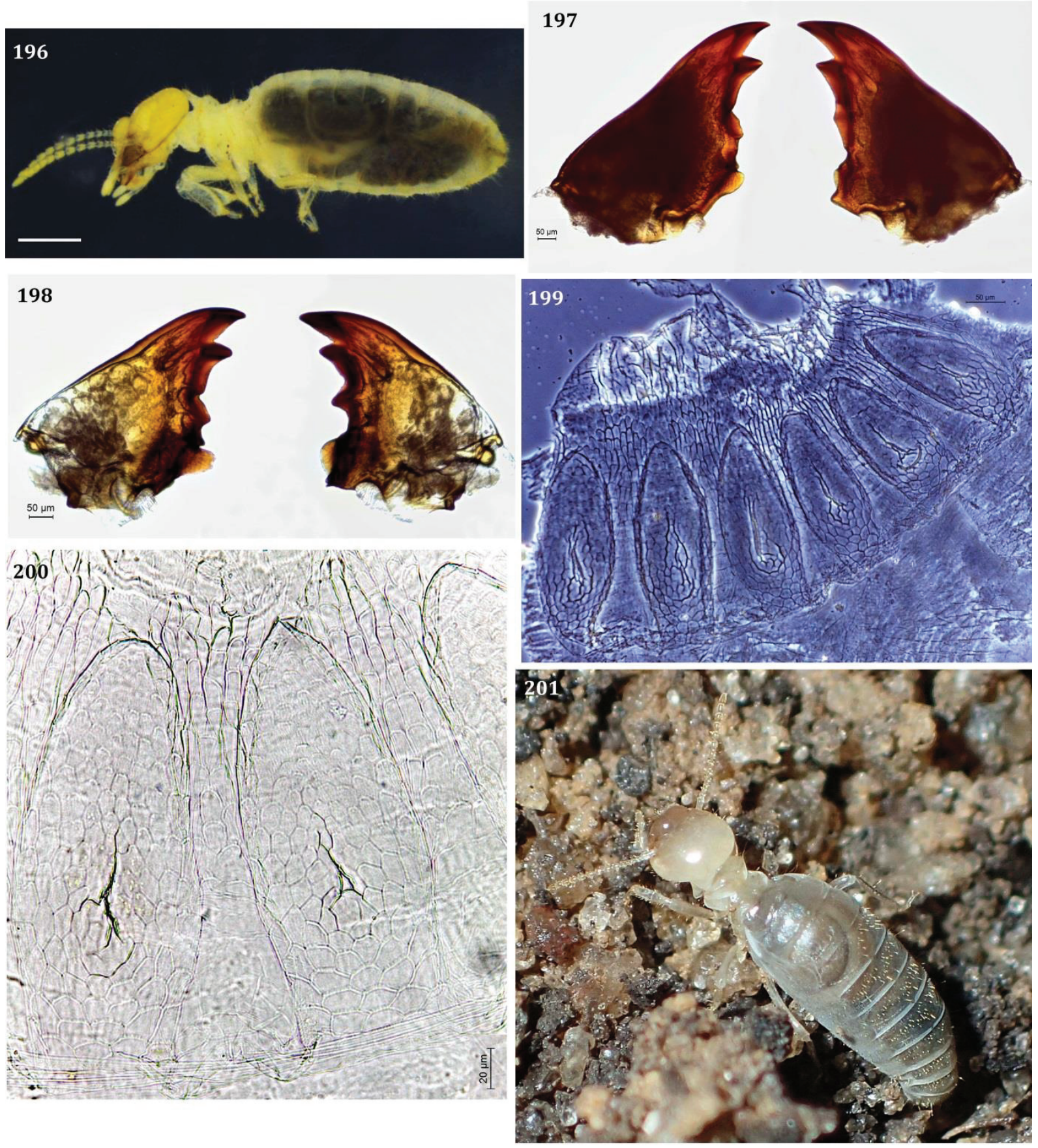

Fig. 196-201. Gênero 8 sp. S3 (MZUSP 26676). 196- hábito do operário, escala: 0,5mm; 197 mandíbulas do alado; 198- mandíbulas do operário; 199- válvula entérica; 200- detalhe de duas das seis pregas da válvula entérica; 201- imagem do operário no campo. 


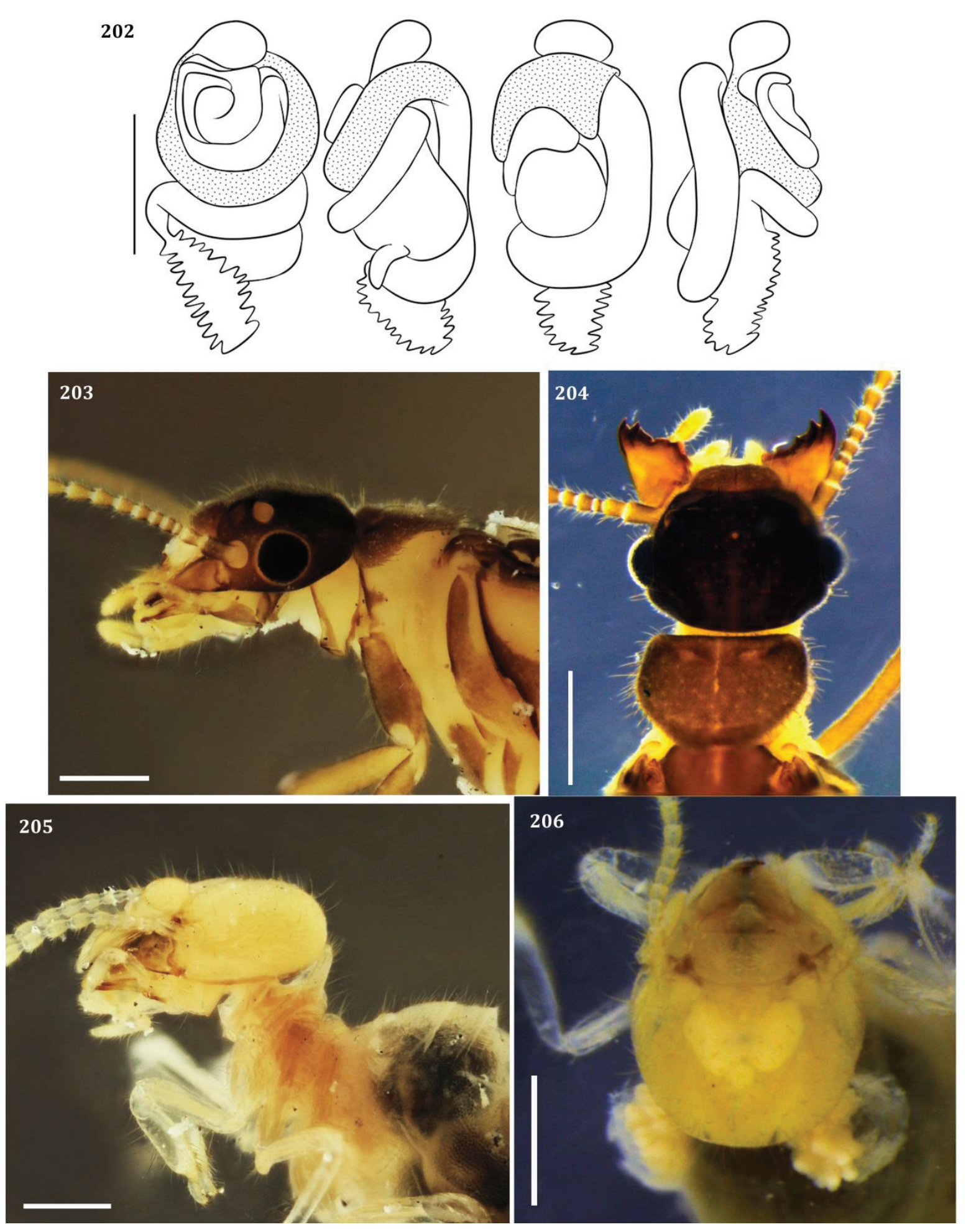

Fig. 202. Gênero 8 sp. S3 (MZUSP 26676), esquema de tubo digestório, escala: 1 mm. Fig. 203206. Gênero 9 sp. V3. 203- alado em vista lateral; 204- alado em vista dorsal; 205- operário em vista lateral; 206- operário em vista dorsal. Escalas: 0,5mm. 

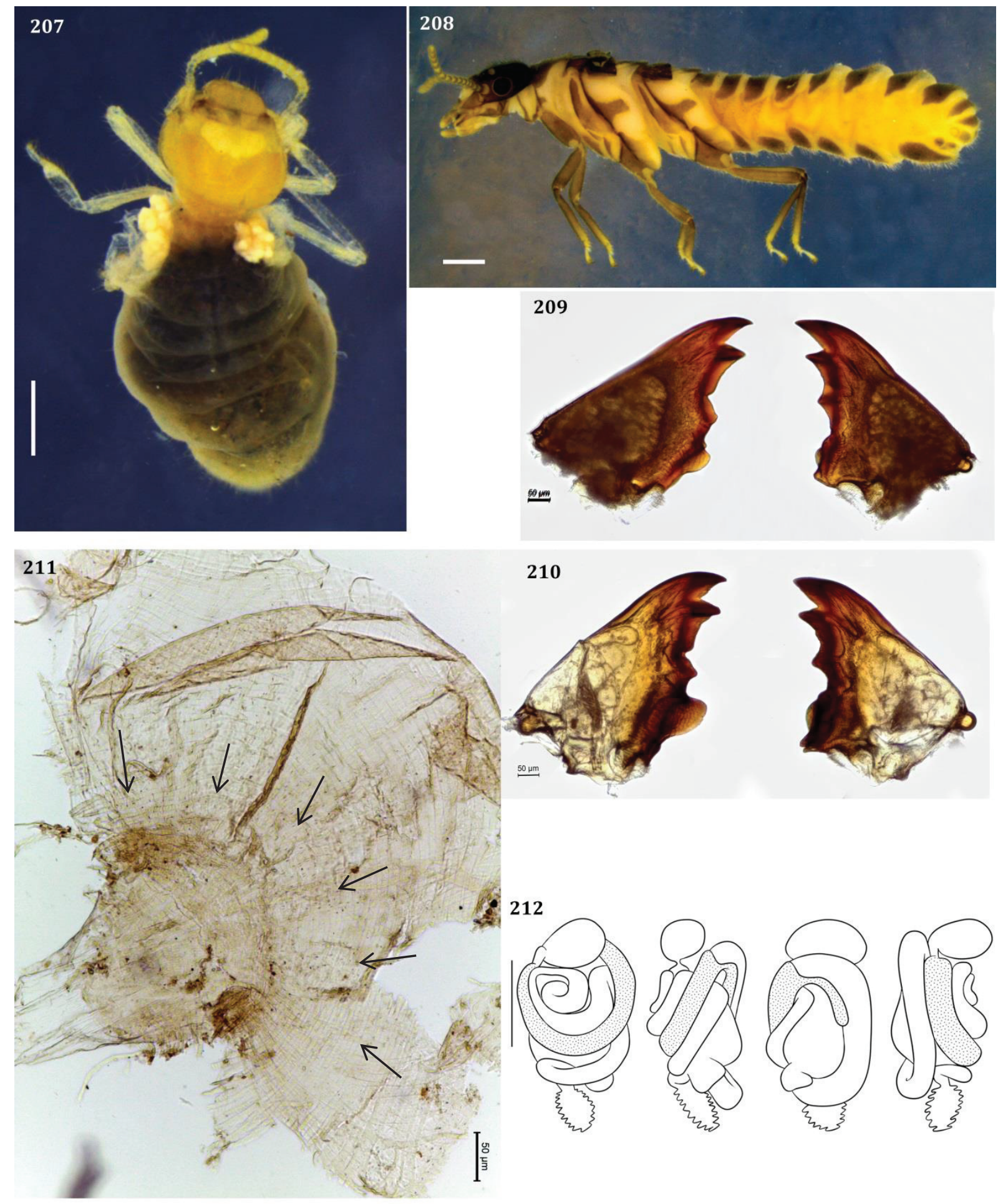

212

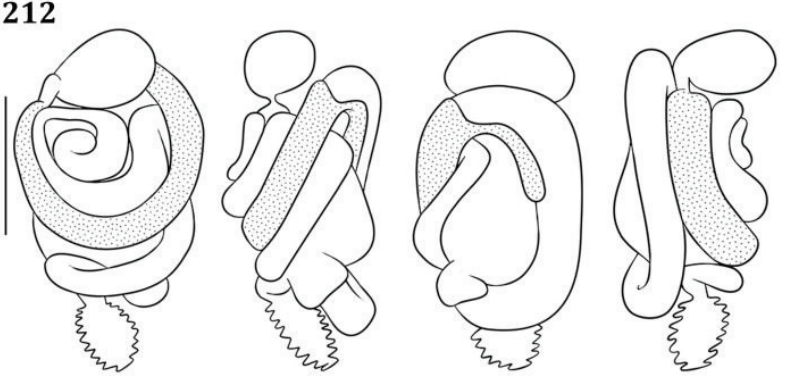

Fig. 207-212. Gênero 9 sp. V3 (MZUSP 25493). 207- operário inteiro em vista dorsal, as setas indicam a região de evaginação dos órgãos deiscentes; 208- hábito da fêmea alada, a seta indica a região da pleura com grande quantidade de cerdas alaranjadas; 209- mandíbulas do alado; 210- mandíbulas do operário; 211-moela, note a ausência dos pulvilli nas áreas indicadas pelas setas; 212- esquema de tubo digestório, escala: $1 \mathrm{~mm}$. Escalas: 0,5 mm. 


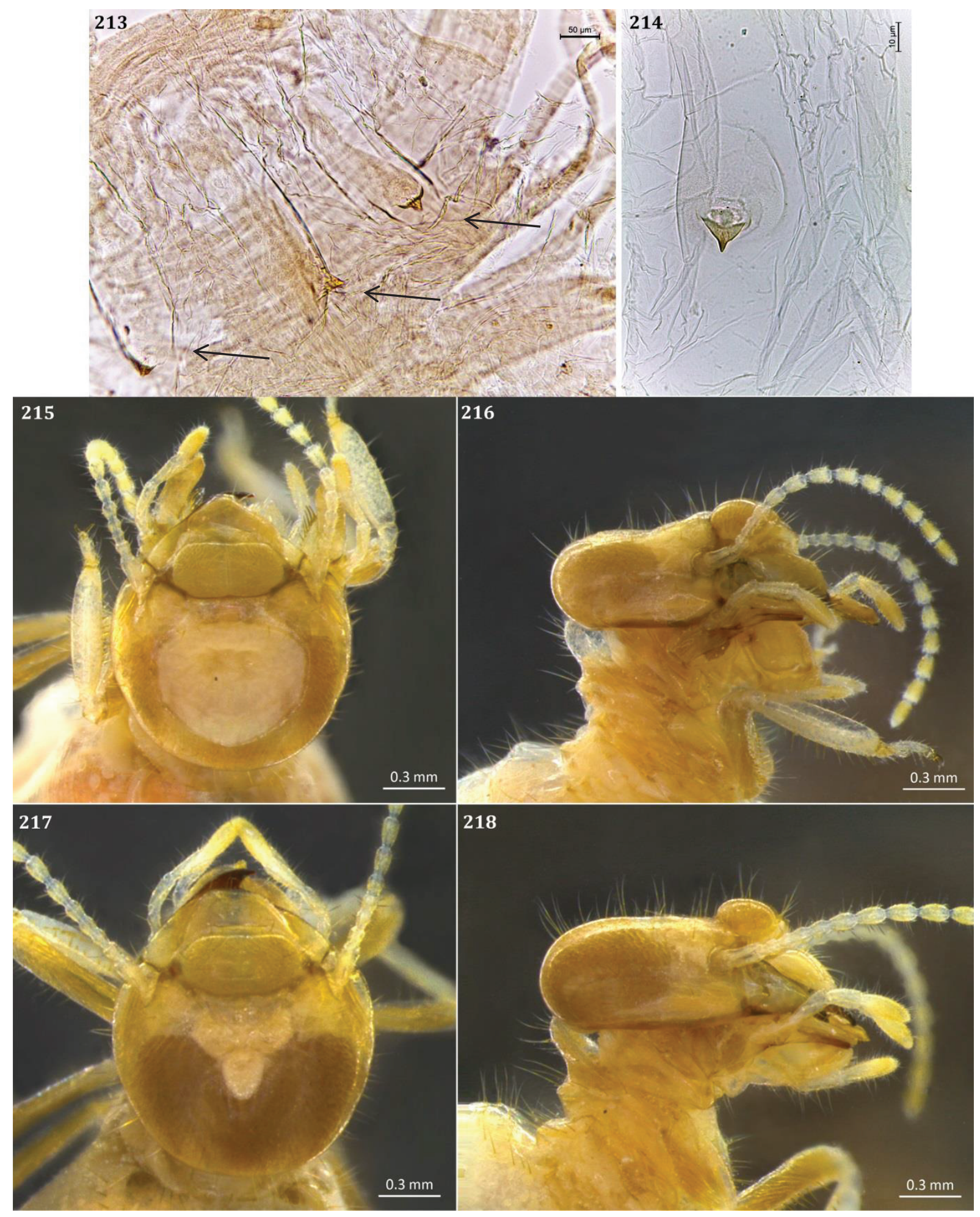

Fig. 213-214. Gênero 9 sp. V3 (MZUSP 25493). 213- detalhe de três das seis pregas da válvula entérica (muita musculatura, as setas indicam as pregas); 214 - detalhe de uma das pregas da válvula entérica. Fig. 215-218. Gênero 10 sp. FonA (MZUSP 6480). 215- operário 1 em vista dorsal; 216- operário 1 em vista lateral; 217- operário 2 em vista dorsal; 218- operário 2 em vista lateral. 


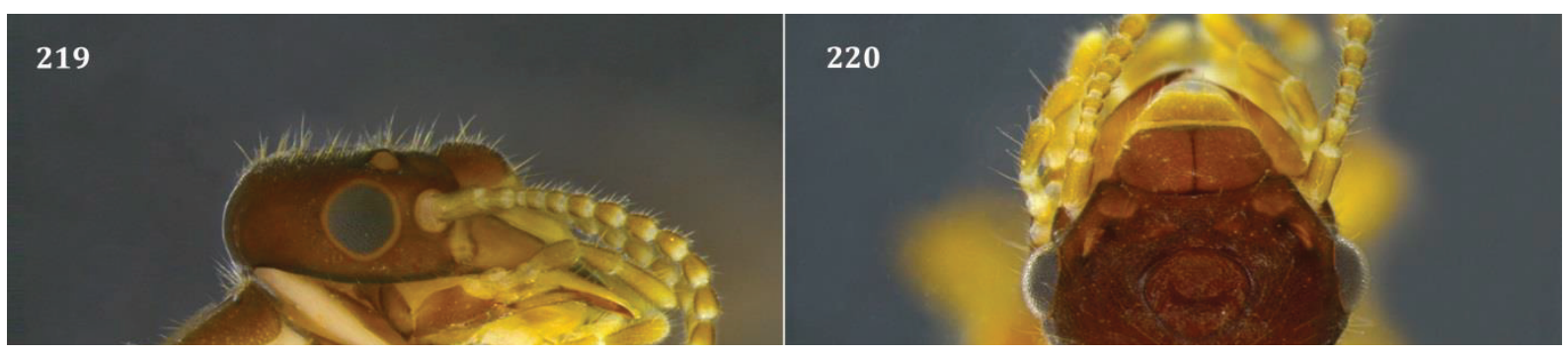

Fig. 219-224. Gênero 10 sp. FonA (MZUSP 6480). 219- alado em vista lateral; 220- alado em vista dorsal; 221- mandíbulas do alado; 222- mandíbulas do operário; 223- detalhe da tíbia anterior com cerdas espiniformes (MEV); 224- tubo digestório, escala: $1 \mathrm{~mm}$. 